\title{
2021
}

EL PAPEL DEL ESTADO EN LA ECONOMÍA

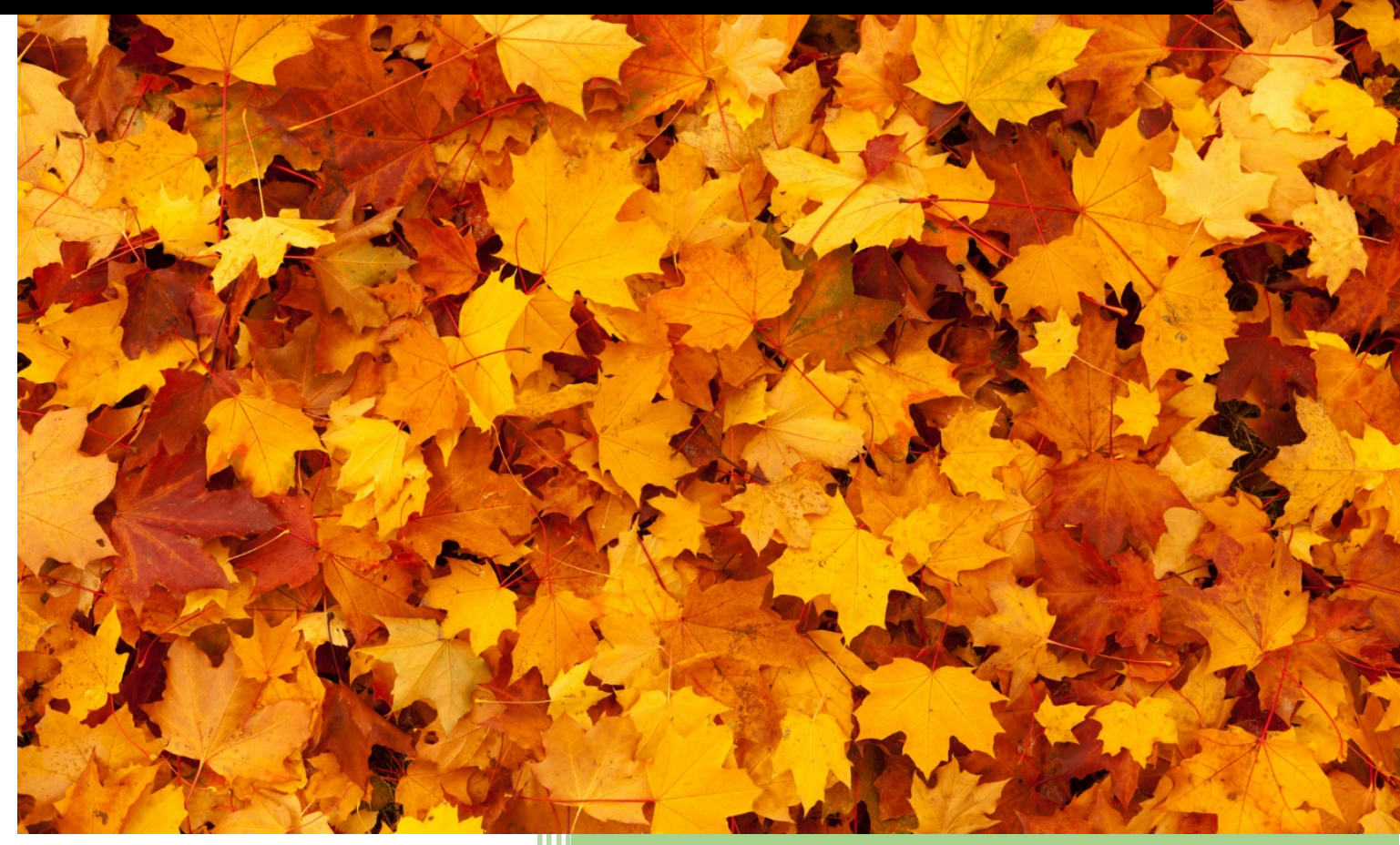

Fernando García García

Creative Commons Attribution 4.0 (CC BY) 
Fernando García García

\section{EL PAPEL DEL ESTADO EN LA ECONOMÍA}



"Solo no puedes, con amigos sí."

La Bola de Cristal 



\section{PREFACIO}

Este libro no es un libro de texto ni un manual donde se trata de forma sistemática y pormenorizada el papel del Estado en la economía. Al lector que busque un manual, le recomiendo el de Stiglitz, "La economía del Sector Público", donde se explica todo mucho mejor de lo que pudiera hacerlo yo. Eso sí, algunas partes del libro son un poco densas para el lector profano en la materia. También es muy recomendable el manual de Bustos Gisbert, "Lecciones de Hacienda Pública I. El papel del Sector Público".

Aunque he procurado ser riguroso con el empleo de los conceptos económicos, el objetivo de este ensayo no es presentar las diferentes teorías y compararlas. El objetivo es, por un lado, simplificar la complejidad que entraña el análisis del papel del sector público en la economía y mostrar el impacto de esa intervención en nuestras vidas. Por otro, y casi que principalmente, invitar a la reflexión.

El enfoque del libro no es en absoluto objetivo. Contrariamente a lo que se nos quiere hacer creer, la economía no es una ciencia pura y las diferentes teorías siempre se sustentan en ideologías políticas. No existen los llamados "tecnócratas" apolíticos. Por eso, he comenzado el ensayo mostrando claramente cuál debe ser, desde mi punto de vista subjetivo y personal, el papel del Estado, que no es otro que facilitar un contexto económico y social en el que las personas, bajo su propia responsabilidad, puedan intentar ser felices. Realmente se trata de un objetivo muy controvertido y, de hecho, la problemática de la felicidad personal no aparece en ningún libro de texto de economía. En teoría económica se habla de conceptos, también abstractos, como curvas de utilidad, o de prestar unos servicios o producir unos bienes de forma Paretoeficiente. Nos enredamos en teorías varias y no se subraya ni se expresa con suficiente claridad el verdadero objetivo que se persigue que, al menos desde mi punto de vista, debe ser el bienestar de las personas. ¿Cómo acaban afectando las diferentes opciones económicas a mi vida? $\mathrm{Y}$ no sólo en términos de bienestar económico, sino también a mis derechos y libertades, teniendo en cuenta que el poder político y el poder económico siempre están interrelacionados. Este es un factor de suma importancia, el de la concentración 
del poder económico, que se olvida actualmente en casi todos los debates de política económica. Y, probablemente, sea el factor más importante y determinante de todos.

Si bien la teoría económica está muy evolucionada y describe muy bien las distintas opciones en cuanto a la intervención del Estado en la economía, así como sus potenciales ventajas e inconvenientes, en este ensayo he huido, en términos generales, del empleo de modelos económicos. La única excepción es el modelo de mercados de competencia perfecta, que es relativamente sencillo e intuitivo y alrededor del cual se basa toda la argumentación del libro.

Los modelos económicos son simplificaciones más o menos burdas de la realidad que nos permiten intentar comprender a grandes rasgos situaciones extraordinariamente complejas. Nos sirven para tener una idea aproximada de lo que es posible que ocurra cuando se dan determinadas circunstancias. Pero no podemos cuantificar exactamente cómo y cuándo un evento afecta a todos y cada uno de los actores y variables en la economía. Si fuera así de sencillo, no se fallaría constantemente con las predicciones y no habría crisis económicas. En economía, los modelos no nos proporcionan, ni mucho menos, verdades absolutas. De hecho, resulta muy, pero que muy complicado verificar la validez de modelos macroeconómicos, al contrario de lo que pasa con las ciencias puras. Los economistas no disponen de laboratorios en los que meter a millones de personas en unas condiciones concretas durante varios años para poder analizar qué sucede. Lo máximo que se puede hacer es observar la historia y ver qué sucedió durante cierta época e intentar identificar las causas, analizando los diferentes casos y situaciones. A nivel microeconómico sí que se están haciendo avances significativos gracias a la economía conductual, en la que sí se hacen experimentos en laboratorio para analizar el comportamiento de las personas, con resultados muy interesantes, por cierto.

Intentar abordar el análisis económico desde una perspectiva cuantitativa nos enfrenta a numerosos problemas, pues no se suele disponer de bases de datos fiables que abarquen suficientes años, para diferentes países, regiones y sectores económicos, que sean comparables, sin cambios estructurales, y que incluyan suficientes variables. Además, las variables económicas presentan problemas que dificultan su tratamiento econométrico, como las correlaciones 
espurias, las variables de las que no se disponen datos y son omitidas, la necesidad de analizar las correlaciones parciales o la existencia de tendencia en las series de datos.

Todas estas dificultades explican que podamos encontrar trabajos de investigación que hablen en un sentido y otros que lo hagan en el sentido diametralmente opuesto. $Y$ todos estos problemas nos deben poner en alerta frente a aquellos políticos que dicen que solo hay una posible opción económica a seguir para alcanzar el objetivo sacrosanto del crecimiento económico, la que respaldan los científicos de la economía, apolíticos ellos, que analizando los números han alcanzado el conocimiento absoluto e irrebatible.

Actualmente, las opciones políticas oscilan entre dos polos. En el primero, el Estado desarrolla un papel fundamental en la economía, mientras que en el segundo su papel es meramente residual, quedando la economía en manos de la "mano invisible" del mercado.

Una de las tesis del ensayo es que para determinar el equilibrio entre el papel del Estado y el papel de la iniciativa privada hay que analizar el control que se pueda ejercer en cada situación sobre el Estado y sobre las empresas. Se trata de evitar abusos de posiciones dominantes que generan ineficiencias económicas y que redundan en una pérdida de bienestar de las personas. Para que haya control tiene que haber reparto de poder, es decir, se tiene que luchar activamente contra una concentración de poder excesiva. Porque los problemas aparecen indudablemente cuando no hay control.

Así, unos políticos que no se sienten vigilados por la ciudadanía pueden tener más incentivos para actuar en su propio interés económico que no en favor del interés general, como demuestran los numerosos casos de corrupción y como explico en el libro "Participación ciudadana, democracia y crisis económica". En estos casos, la actuación del Estado será desastrosa. Por otro lado, las empresas, si no están controladas por el Estado, podrían, entre otras cosas, evitar la competencia mediante acuerdos y aumentar el precio de sus productos, o contaminar el agua, el suelo y el aire alegremente, o vender productos nocivos, con las consecuentes repercusiones negativas para los consumidores y los ciudadanos en general. 
Las principales tesis que se irán desgranando a lo largo del libro son las siguientes:

1. El Estado no es responsable de la felicidad de cada persona, pero sí desempeña un rol fundamental a la hora de crear un contexto en el que cada persona se pueda desarrollar como tal.

2. Este contexto incluye el fomento y la protección de ciertos derechos y libertades personales, así como un marco económico que permita satisfacer las necesidades personales básicas.

3. Para garantizar el bienestar económico elemental de la forma más eficiente, el Estado debe intervenir en la economía siempre y cuando los mercados no funcionen como mercados de competencia perfecta, o para subsanar los fallos inherentes a estos mercados. Esto incluye actuar para alcanzar objetivos que los ciudadanos no pueden alcanzar sin una coordinación a gran escala.

4. La intervención del Estado en la economía, por sí misma, no garantiza el éxito, dependiendo éste del tipo de intervención y su intensidad, que a su vez dependerán de la orientación política o intereses personales de quienes tomen las decisiones estatales. La política económica nunca es neutral ni ajena a ideologías, no es una ciencia exacta y está cargada siempre de motivaciones ideológicas.

5. Es fundamental evitar la concentración de poder. Deben existir vías efectivas que permitan el control constante de los poderes del Estado por parte de los ciudadanos. Además, el Estado debe controlar al poder económico, vigilando la excesiva concentración, pues el poder económico puede a su vez manipular al propio Estado democrático. 


\section{INDICE}

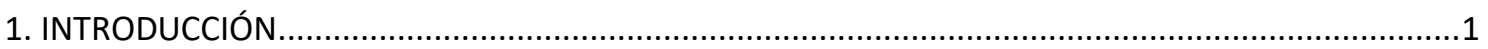

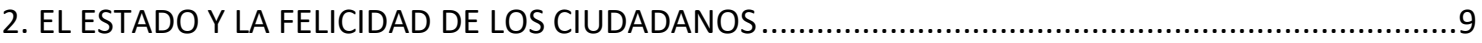

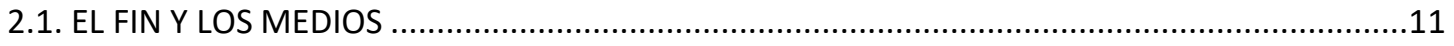

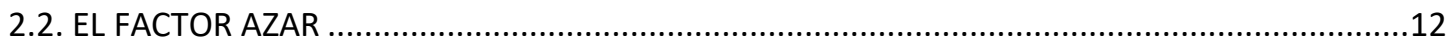

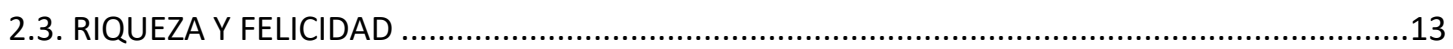

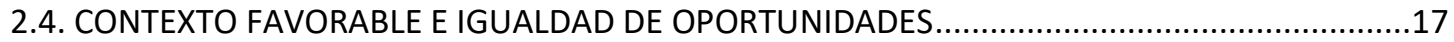

2.5. LAS ÁREAS DE INTERVENCIÓN DEL ESTADO EN LA ECONOMÍA ............................................18

2.6. EL PAPEL DEL ESTADO EN LA CONSTITUCIÓN ESPAÑOLA......................................................19

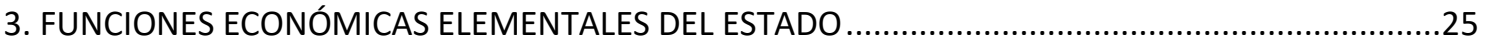

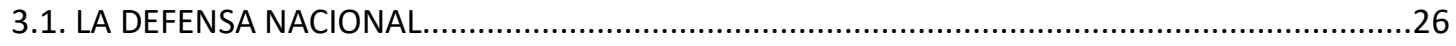

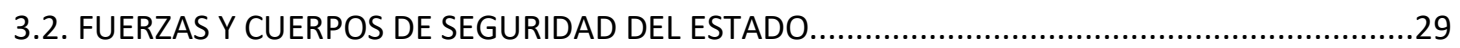

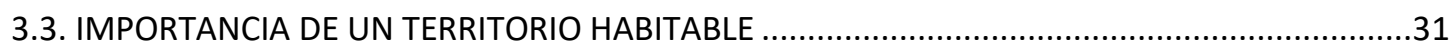

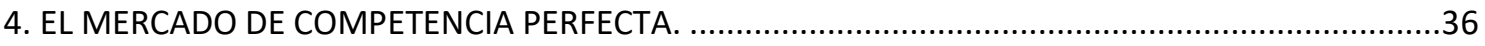

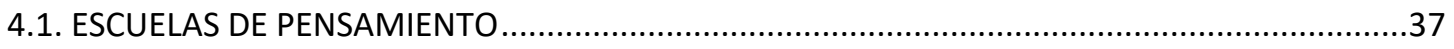

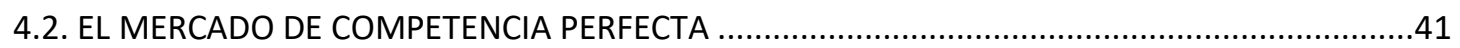

4.3. CÓMO EVITAR LA COMPETENCIA Y AUMENTAR LOS BENEFICIOS .......................................44

4.4. EL PAPEL DEL ESTADO COMO GARANTE DE LA COMPETENCIA ENTRE EMPRESAS..................47

5. LOS FALLOS DEL MERCADO DE COMPETENCIA PERFECTA …............................................................

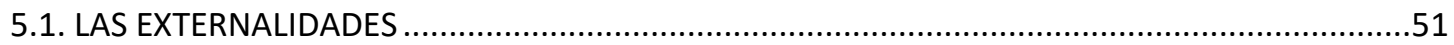

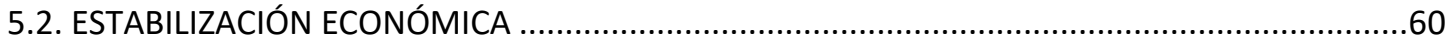

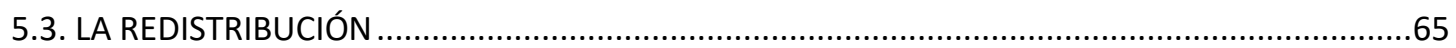

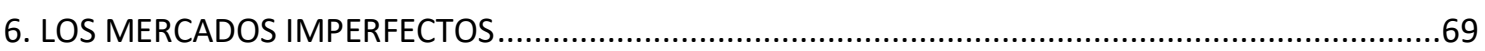

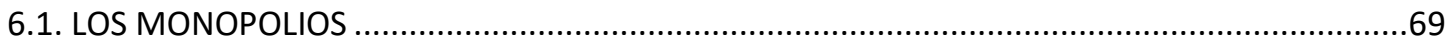

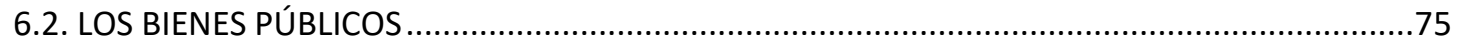

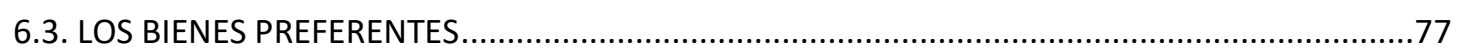

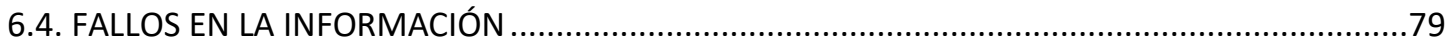

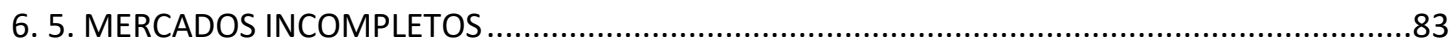

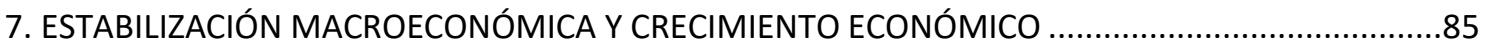




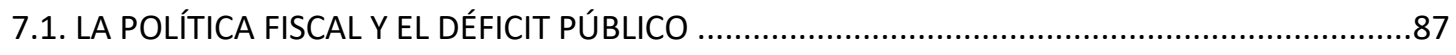

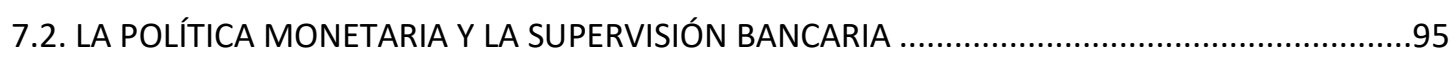

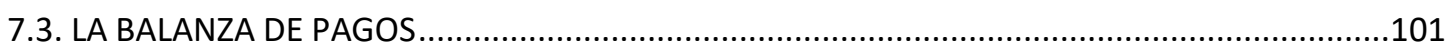

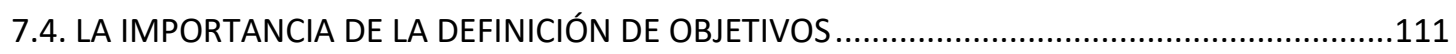

7.4.1. EL PIB COMO OBJETIVO DE LA POLÍTICA ECONÓMICA ……......................................112

7.4.2. EL EMPLEO COMO OBJETIVO DE LA POLÍTICA ECONÓMICA ........................................114

7.4.3. LA INFLACIÓN COMO OBJETIVO DE LA POLÍTICA ECONÓMICA .....................................117

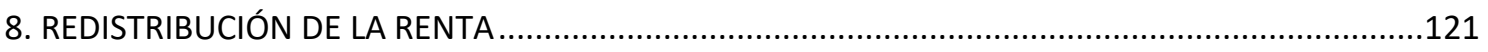

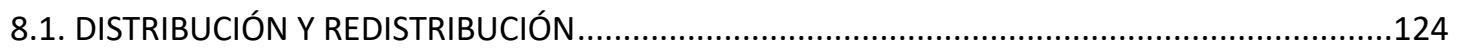

8.2. ARGUMENTOS CONTRA LA ACTUACIÓN REDISTRIBUTIVA DEL ESTADO …...........................127

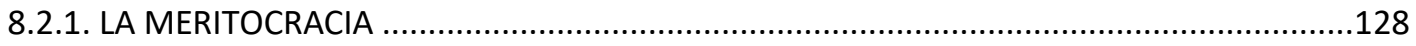

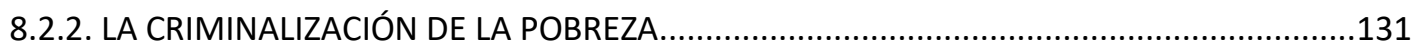

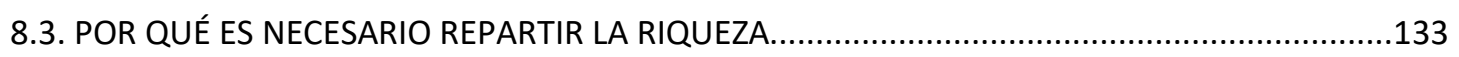

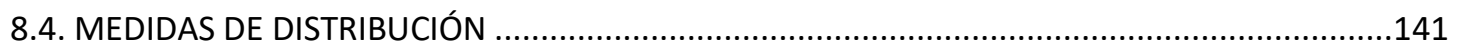

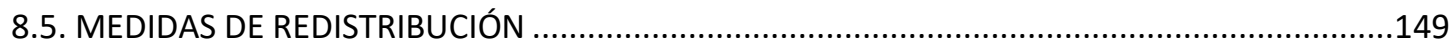

8.5.1. LOS IMPUESTOS Y SU FUNCIÓN REDISTRIBUTIVA ......................................................150

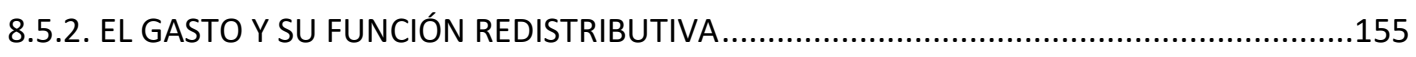

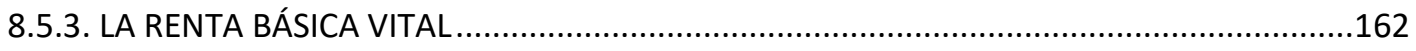

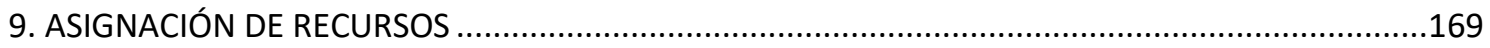

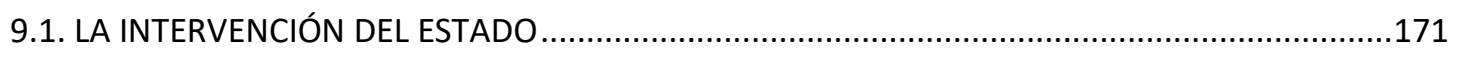

9.2. DIFICULTADES EN EL DISEÑO DE POLÍTICAS DE ASIGNACIÓN DE GASTO ...............................174

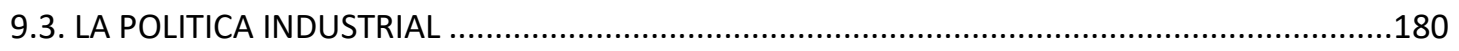

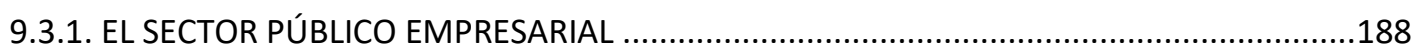

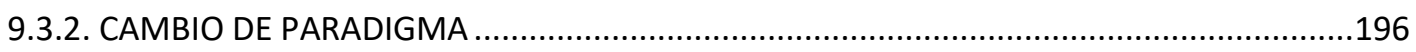

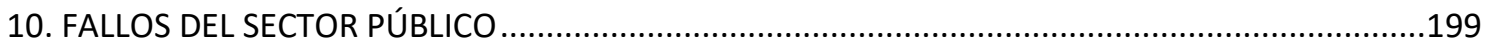

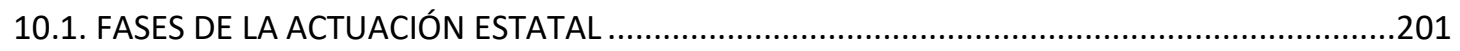

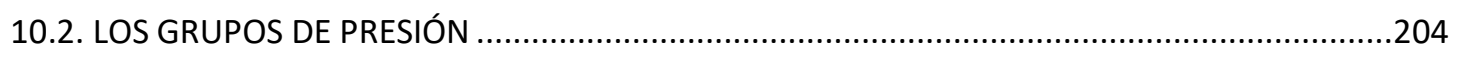

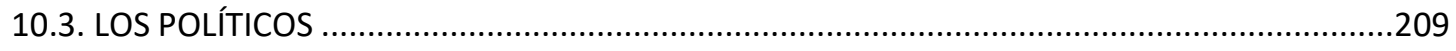

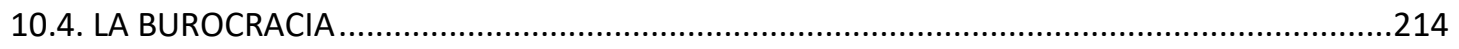

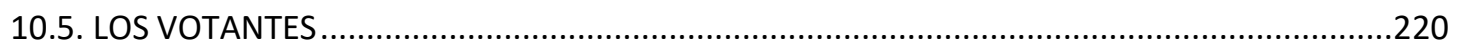

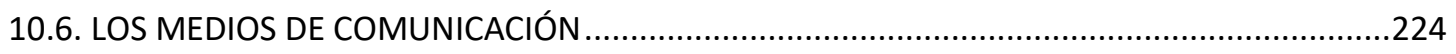

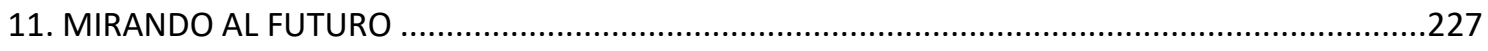




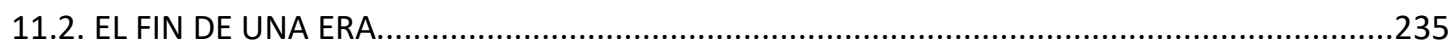

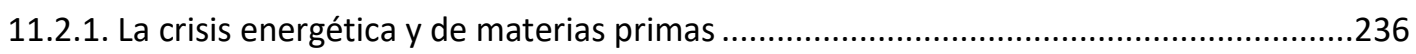

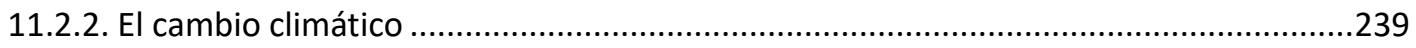

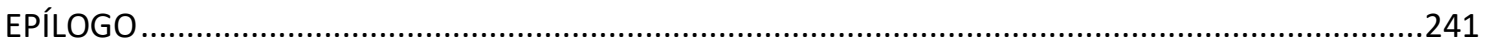

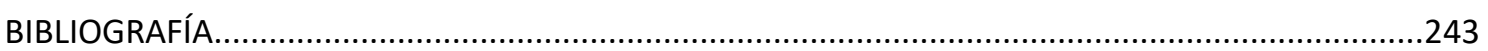





\section{INTRODUCCIÓN}

El papel que desempeña el Estado en nuestras vidas es enorme, si bien muchas veces pasa desapercibido y solo nos acordamos de la existencia del Estado cuando tenemos que enfrentarnos a su burocracia o nos toca pagar impuestos. Los que hemos nacido en España tenemos la enorme suerte, no siempre suficientemente ponderada, de haber nacido en un Estado consolidado que, si bien tiene aún grandes posibilidades de mejora y siempre se corre el riesgo de involución, ofrece a la mayoría de sus ciudadanos un contexto muy favorable para su desarrollo personal.

En principio, en España, el Estado nos garantiza seguridad personal y la protección de nuestras propiedades. Se protegen los derechos humanos y disfrutamos de libertades como la libertad de residencia y de circulación con absoluta normalidad. Especial mención merece el caso de las mujeres, la mitad de la población, que son tratadas como objetos en otros muchos países y aquí se les reconoce la igualdad con los hombres, aunque sigue siendo un campo en el que se debe trabajar mucho hoy en día a efectos prácticos.

Además, contamos con sistemas de coberturas sociales que nos protegen de diversas adversidades como la enfermedad o el desempleo. Cuando llegamos a cierta edad, nos podemos jubilar y cobraremos una pensión. No nos paramos a pensar que hace tres generaciones eso de la jubilación no existía. Ni el seguro por desempleo. O que, hoy en día, incluso en países más ricos que el nuestro, las personas pueden morir por no poder sufragar el coste de una operación o una medicación, algo que en España sería inconfesable, pero que en otros países consideran perfectamente justificable. $\mathrm{Y}$ si no trabajan un día porque están enfermos, no cobran.

Los españoles disfrutamos de un sistema educativo obligatorio gratuito y educación superior de calidad más que aceptable asequible para toda la población.

Las empresas pueden prosperar gracias a un entorno jurídico, económico y social creado y sostenido por el Estado, así como a una red de infraestructuras 
que ha mejorado extraordinariamente desde la entrada de España en la CEE, la actual Unión Europea.

El Estado está en nuestras vidas desde que nacemos hasta que se certifica nuestra defunción.

Cualquier análisis del papel del Estado en España debe partir necesariamente del reconocimiento de los grandes logros que se han alcanzado. Para ser conscientes de ellos, defenderlos y seguir avanzando.

$Y$ es que, en términos mundiales, la situación española es una excepción. Muchos países no son verdaderos Estados, pues los Gobiernos no pueden garantizar ni la integridad territorial ni la seguridad física de sus habitantes. Otros países han adoptado formas de Gobierno autoritarias donde el Estado no respeta los derechos humanos.

En cualquier caso, el papel que desempeña el Estado, también en el ámbito de la economía, es una decisión política. No hay ninguna argumentación científica válida que determine que el Estado deba actuar de una manera concreta y no de otra pues, en última instancia, depende de cuál sea el resultado que se busque. Por ejemplo, la igualdad de las personas no importaba a las sociedades esclavistas y los derechos de los obreros tampoco estaban en la agenda política hasta la segunda mitad del siglo XIX. Hoy en día muchos Estados desprecian los derechos humanos o la protección del medio ambiente, de palabra y obra.

Por lo tanto, es imprescindible que seamos conscientes, desde el primer momento, de que la situación que tenemos en España, nuestra idea de lo que es o debe ser el Estado, es resultado de una evolución histórica concreta. No es la única posible. $\mathrm{Y}$ no es ni mejor ni peor, al menos en un primer análisis superficial. Simplemente, depende de para quién. Obviamente, cuando el poder político y económico están muy concentrados en unas pocas manos, por ejemplo en España a lo largo de casi toda su historia o actualmente en países como Arabia Saudí, a estos poderosos les interesa un tipo de Estado diferente del que puede desear la mayor parte de la población. Les interesa un Estado que garantice el statu quo, dando enorme importancia al ejército como medida de defensa frente al exterior y de represión en el interior, olvidando las políticas sociales, que serán inexistentes. 
Cuestión diferente es que, como demuestra la historia, durante los largos siglos en los que el poder ha estado concentrado en grupos muy reducidos, la mejora en la calidad de vida haya sido ridícula. Esto ha sido así en todas las épocas y regiones. Hoy en día, cualquier ciudadano español disfruta de mejor calidad de vida en términos materiales que el mismísimo Luis XIV de Francia, que no tenía ni luz eléctrica, ni televisión, ni ordenador, ni teléfono móvil, ni antibióticos, ni vacunas. Este hecho demuestra que ese modelo de Estado, a medio plazo, también perjudica a los poderosos. Pero, claro, ceder poder siempre cuesta, y cuesta más cuanto más se tiene.

Conforme las sociedades se han ido democratizando y el poder político y económico se ha ido compartiendo y diluyendo, el papel del Estado ha ido modificándose. En términos generales, el Estado se ha ido ocupando paulatinamente de diversas actividades económicas como la construcción de infraestructuras y viviendas, la educación, la sanidad, la seguridad social, el sector financiero, los medios de comunicación, la producción de bienes de consumo, el suministro de servicios y un largo etcétera. Ha pasado de ser exclusivamente un regulador (que ejerce el monopolio de la violencia dentro de sus fronteras para hacer cumplir sus leyes) a ser un actor principal en numerosos mercados.

Este aumento de la participación estatal ha ido acompañado siempre de un aumento del gasto público, lo que implica que se deben recaudar más impuestos. Este hecho, obviamente, ha sido objeto de crítica. Además, en el campo de la regulación, algunos aprecian una intromisión demasiado grande del Estado que impide el correcto funcionamiento de los mercados, por ejemplo en el mercado laboral o incluso en el ámbito de las finanzas.

Vemos, pues, cómo ante el crecimiento del sector público y la mayor actuación del Estado existe una corriente de pensamiento que aboga por limitarla y que no está carente de razón.

¿Qué es lo que debe hacer el Estado y qué no en términos económicos? Ya hemos dicho que la contestación a esta pregunta es necesariamente subjetiva. Hasta hace relativamente poco, la función económica del Estado, en 
cualquier parte del mundo, era principalmente garantizar el orden público, administrar justicia y velar por el cumplimiento de los contratos.

Pero, aunque pensemos que el Estado se debe ocupar también de mejorar la calidad de vida de los ciudadanos y deba intervenir más en el ámbito económico, ¿acaso es necesario que actúe directamente? ¿No será en ocasiones más eficiente que deje actuar a la iniciativa privada, limitándose el Estado a regular lo mínimo y vigilar el cumplimiento de las leyes?

Así, en la actualidad, nos encontramos con una corriente ideológica muy relevante e influyente a nivel mundial que, especialmente desde principios de los años 80 , aboga por reducir a la mínima expresión el papel del Estado, tanto en la intervención directa como en la regulación, y dejar en libertad las fuerzas del mercado, que se consideran más eficientes que el sector público.

Este libro se estructura en cinco grandes partes.

En la primera se presenta cuál debe ser, en mi opinión, el principal objetivo económico del Estado en términos generales (Cap.2).

La segunda parte trata las funciones elementales del Estado (Cap.3) y justifica por qué debe actuar el Estado en la economía, es decir, bajo qué circunstancias es conveniente esa actuación y qué problemas debe resolver que no es capaz de solucionar el sector privado o son creados precisamente por éste. Se tratan las bondades y los fallos del mercado de competencia perfecta (Cap.4 y 5) y la problemática de los mercados donde esa competencia perfecta no puede existir (Cap. 6).

La tercera parte trata cómo actúa el Estado en el ámbito de la estabilización macroeconómica y el fomento del crecimiento económico (Cap. 7), la redistribución de la renta (Cap. 8) y la asignación de recursos (Cap. 9).

En la cuarta parte se analizan los problemas que se presentan cuando el Estado interviene en la economía, pues una cosa es que la su intervención esté justificada y otra muy diferente es suponer que el Estado siempre vaya a actuar correctamente (Cap. 10). 
La quinta y última parte del libro presenta algunas reflexiones acerca de cuál debe ser el papel del Estado en la economía en el futuro inmediato, teniendo en cuenta algunas amenazas que se ciernen sobre nuestras sociedades (Cap. 11).

Así, partiendo del referente del Estado español, se explicita, en primer lugar, cuál debe ser, en mi opinión, la principal función del Estado, que no es otra que la de crear un contexto económico y social donde los ciudadanos puedan buscar su felicidad, de la cual son responsables única y exclusivamente las personas a título individual. Este contexto económico y social requiere que el Estado garantice la seguridad del territorio, la seguridad física y el orden público, así como un territorio habitable. El Estado debe garantizar los derechos humanos y la participación ciudadana en un sistema democrático. Y también que todas las personas, y muy especialmente los niños y las niñas, gocen de igualdad de oportunidades, en el sentido de que nadie se vea desfavorecido por no poder acceder a recursos básicos como la alimentación o la vivienda, la sanidad o la educación básica y la cultura.

Alcanzar todos estos objetivos implica, necesariamente, que el Estado participe en la economía de diferentes maneras. Alcanzar estos fines no es posible sin la actuación estatal. Efectivamente, como se trata en el segundo bloque del libro, los mercados libres presentan fallos que hacen que inevitablemente surjan ciertas ineficiencias, además de aumentar las desigualdades sociales en lugar de reducirlas. La probable concentración de poder en manos de pocas empresas pone en peligro la misma existencia de los mercados competitivos. Por otro lado, se producen desequilibrios económicos y problemas medioambientales, porque los mercados sin regular no fomentan la economía sostenible. Así pues, es muy importante conocer las causas que hacen necesaria la partición directa del Estado en la economía. Se verá cómo, en principio, los mercados de competencia perfecta son la opción más eficiente, por lo que el Estado debe protegerlos y fomentarlos frente a otros mercados, como los monopolios. No obstante, incluso los mercados perfectamente competitivos presentan fallos graves que obligan al Estado a intervenir. A continuación comentaremos brevemente cómo se articula la intervención estatal mediante políticas macroeconómicas, políticas redistributivas y políticas de asignación de recursos. 
En cualquier caso, el hecho de que el Estado intervenga no implica que lo haga de forma acertada. Por desgracia, los españoles, pero lo mismo ocurre en todos los países, estamos acostumbrados a la ineficiencia del sector público. En su representación más extrema aparece la corrupción, el saqueo de las arcas públicas que no se justifica por ninguna teoría económica, pero que es sencillo comprender al pensar en los incentivos personales que mueven a muchos gestores públicos. Este escandaloso despilfarro en el uso del erario público, así como una desviación tremenda entre los fines que supuestamente se buscan y las acciones que se acometen, causa gran indignación en la ciudadanía y muchos se preguntan si no sería mejor reducir el tamaño del sector público y dejar hacer a las empresas, aun cuando sean un poco ineficientes según la teoría.

La conclusión principal es que la ineficiencia, tanto en el sector público como en el privado, surge de la falta de control externo. En el caso del sector empresarial, ese control lo aportan la competencia y la regulación, mientras que al sector público lo deben vigilar, en última instancia, los ciudadanos, aunque también hay otras vías como los organismos fiscalizadores, la justicia o la prensa.

Por un lado, no se puede justificar el mito de que la gestión privada siempre es mejor que la pública. Pero, por otro lado, el Estado debiera priorizar sus actuaciones, siempre subordinadas a los fines que se deseen alcanzar, que deben ser claros, y centrarse en aquellas en las que su participación permita aumentar la eficiencia del sector privado o resolver sus fallos.

La opción del mercado libre que funciona perfectamente defendida por algunas escuelas económicas no es, en mi opinión, factible ni real. Para empezar, por la existencia de los numerosos fallos que hay en los mercados. Así, el capitalismo en su versión más pura no puede existir en la práctica a medio plazo, como se demostró en la crisis de 1929 en EEUU, lo mismo que el comunismo puro no se puede implementar. Lo curioso es que casi todos los que defienden el sistema capitalista a ultranza, o solo quieren una participación mínima del Estado, sí que se aprovechan del poder del Estado cuando les resulta provechoso, como por ejemplo en el caso de los rescates de grandes empresas, o para explotar concesiones, recibir jugosos contratos de la Administración Pública, subvenciones millonarias o desempeñar puestos en el sector público. En 
realidad, no defienden una verdadera economía liberal, sino un capitalismo "de amiguetes" en el que se utiliza el poder del Estado para beneficiar a ciertas empresas y grupos de presión. Ciertamente, no debiéramos hablar de "capitalismo" sino de "neomercantilismo", enemigo del pensamiento liberal. Así, se pone de manifiesto una vez más lo nefasto de la concentración del poder económico y cómo el poder económico puede llegar a dirigir a un poder político que se siente liberado del control de los ciudadanos, a su vez objeto de campañas de manipulación masivas dirigidas por el poder económico.

En términos generales, podemos concretar diciendo que el papel del Estado en la economía se debería centrar en mejorar la eficiencia, la equidad y la estabilidad económica. Tradicionalmente también se le suele asignar el fomento del crecimiento económico a corto y largo plazo, pero en la actualidad se cuestiona que el crecimiento ilimitado y a cualquier precio sea beneficioso, pues puede generar enormes problemas medioambientales, entre otros.

Las empresas privadas, ni buscan estos fines ni tienen herramientas para alcanzarlos. Por su parte, el Estado sí puede intervenir en la asignación de recursos y en el funcionamiento de los mercados, participando directamente en la producción de bienes y servicios, con medidas de redistribución de la renta o mediante la regulación de la actividad económica.

Alcanzar estos fines exige gran cantidad de recursos materiales. La siguiente tabla muestra el tamaño del sector público de algunos países seleccionados, los 30 países con mayor PIB en 2019. La primera cuestión es: ¿En qué países nos gustaría vivir o haber nacido? ¿En los que el sector público es más grande o más reducido? La segunda cuestión es similar pero el revés. Pensemos en los países que identificamos como los que disfrutan de mayor nivel de vida y bienestar. El sector público de estos países, ¿es de tamaño grande o reducido? Obviamente, el tamaño del sector público nos indica si el Estado interviene más o menos directamente en la economía, con independencia de que además pueda utilizar el instrumento de la regulación. Por otro lado, el gasto del Estado se puede destinar a diversos fines, con repercusiones muy diferentes en la población, de manera más o menos eficiente. 
Pero sirva este ejercicio para que el lector cuantifique el grado de participación estatal en las diferentes economías y lo relacione de forma intuitiva con la calidad de vida de los ciudadanos. Y ver dónde se puede acabar si se reduce mucho la participación estatal.

\begin{tabular}{|l|r|}
\hline \multicolumn{1}{|c|}{ País } & $\begin{array}{c}\text { Gasto estatal total / } \\
\text { PIB }\end{array}$ \\
\hline France & $55,7 \%$ \\
\hline Belgium & $52,1 \%$ \\
\hline Italy & $48,8 \%$ \\
\hline Sweden & $48,4 \%$ \\
\hline Norway & $48,1 \%$ \\
\hline Austria & $47,9 \%$ \\
\hline Germany & $45,2 \%$ \\
\hline Poland & $42,8 \%$ \\
\hline Netherlands & $42,8 \%$ \\
\hline Spain & $41,3 \%$ \\
\hline Canada & $40,7 \%$ \\
\hline Saudi Arabia & $39,0 \%$ \\
\hline United Kingdom & $38,4 \%$ \\
\hline Brazil & $38,3 \%$ \\
\hline Argentina & $37,6 \%$ \\
\hline Japan & $37,0 \%$ \\
\hline Australia & $36,7 \%$ \\
\hline United States & $36,2 \%$ \\
\hline China & $34,9 \%$ \\
\hline Turkey & $34,8 \%$ \\
\hline Russia & $33,9 \%$ \\
\hline Switzerland & $32,5 \%$ \\
\hline India & $27,1 \%$ \\
\hline Mexico & $25,7 \%$ \\
\hline Korea & $22,1 \%$ \\
\hline Thailand & $21,6 \%$ \\
\hline Islamic Republic of Iran & $17,3 \%$ \\
\hline Taiwan Province of China & $17,3 \%$ \\
\hline Indonesia & $16,3 \%$ \\
\hline Nigeria & $12,7 \%$ \\
\hline & \\
\hline &
\end{tabular}

Tabla 1. Comparación del tamaño del sector público en los países con mayor PIB en 2019 Fuente: Fondo Monetario Internacional 


\section{EL ESTADO Y LA FELICIDAD DE LOS CIUDADANOS}

Este capítulo es, necesariamente, el más subjetivo. Se trata, honradamente, de exponer una opinión personal que el lector podrá o no compartir. No obstante, definir cuál es el fin último que se persigue con la actuación del Estado es de una importancia tremenda. De hecho, toda la teoría económica en relación al papel del Estado debería girar en torno a la respuesta que se obtenga de la pregunta: ¿Cuál es la finalidad del Estado, en último término?

A esta pregunta podemos encontrar muchas respuestas que, en mi opinión, no son completamente satisfactorias. Así, cuando se dice que una función del Estado es fomentar la estabilidad económica, a mi esa función se me antoja una respuesta parcial que hace referencia a un medio, no un fin en sí mismo. Lo mismo ocurre cuando se habla de garantizar la seguridad nacional, buscar el pleno empleo o proteger el medio ambiente. Desde mi punto de vista, todos estos objetivos, que son importantes, no dejan de ser medios más o menos necesarios para alcanzar lo que yo considero la verdadera función del Estado: ofrecer un entorno social y económico que permita que las personas se puedan desarrollar como tales, buscar su plenitud personal y tratar de ser felices.

En mi opinión, el análisis de toda actuación estatal se debe hacer desde el prisma de este objetivo. Insisto: en toda actuación estatal, para calificar si una política es o no adecuada o pertinente, se debe estudiar en qué medida acaba afectando a los ciudadanos de a pie, a sus derechos y libertades y a su situación económica. No obstante, como la felicidad de las personas no es cuantificable, resulta mucho más sencillo centrarse en otros objetivos que sí lo son. Pero de esta manera se corre el riesgo de confundir los medios con los fines, además de que se olvida cuál debiera ser el verdadero fin, mejorar la vida de las personas. Por otro lado, suele haber grupos de presión interesados en que confundamos los fines con los medios. 
En términos generales, llevar una vida feliz es la máxima aspiración de todas las personas desde que nacemos, con independencia de nuestro sexo, clase social, lugar de nacimiento, raza etc.. Pero la felicidad es algo individual y subjetivo, que cada cual define y busca a su manera. No obstante, alcanzar esa plenitud personal, encontrar el sentido de la vida, es enormemente importante para los seres humanos, como demuestran la importancia e influencia de las religiones y escuelas de pensamiento filosófico a lo largo de la historia. Y, en la actualidad, el éxito comercial de los libros de autoayuda.

Lo que sí que parece bastante claro es que, aunque cada persona es responsable de su propia felicidad, el contexto puede ayudar o dificultar la realización personal, el desarrollo personal. Hay unos mínimos materiales y no materiales que, de no existir, ponen en peligro la propia supervivencia o el equilibrio psicológico. Efectivamente, no se trata solo de limitaciones materiales en términos de comida, casa o vestido. Las personas necesitamos también un contexto que proteja nuestra estabilidad psicológica y nos conceda ciertos derechos y libertades para facilitar nuestro desarrollo físico y mental. Así, desde mi punto de vista, una mujer nacida en Arabia Saudí o India lo tiene más complicado para desarrollar libremente su personalidad que una nacida en Noruega, con independencia de su poder adquisitivo. O un español medio actual tiene más posibilidades de llevar una vida feliz que uno de hace cien años. Vemos, pues, cómo el momento y el lugar de nacimiento tienen una poderosa influencia en la calidad de vida de las personas y, por lo tanto, en el desarrollo de su potencial.

En cualquier caso, un contexto favorable no garantiza, ni mucho menos, que vayamos a ser plenamente felices. De igual manera, se puede ser feliz en entornos muy adversos. Cada persona es, en última instancia, responsable de su propia felicidad. El Estado todo lo que puede hacer es ofrecer un escenario apropiado donde se desarrolla la historia de cada cual. Nada más, ni nada menos. 


\subsection{EL FIN Y LOS MEDIOS}

Si aceptamos la premisa de que el principal papel del Estado en general, y en términos de su papel en la economía en particular, es favorecer la búsqueda personal de la felicidad de sus ciudadanos, generar el "caldo de cultivo", garantizar un entorno socioeconómico en el que los ciudadanos puedan desarrollarse dignamente como personas y puedan buscar su propia felicidad, lo que implica el respeto y el fomento de los derechos humanos, debemos subordinar a este fin todas las actividades del Estado. En este sentido, como hemos mencionado, es muy importante diferenciar entre el fin y los medios, pues es muy habitual olvidar el objetivo principal y pensar que los medios para alcanzarlo son el verdadero fin.

Veamos algunos ejemplos.

Por lo general, la lucha contra el desempleo es un objetivo estatal prioritario. Un empleo satisface, principalmente, dos necesidades. La primera, la económica, pues aporta dinero con el que cubrir las necesidades materiales, otorgando independencia económica. La segunda, permite que las personas se relacionen entre sí y se sientan útiles para lo sociedad, lo que es importante para la autoestima. No obstante, en muchas ocasiones estas necesidades se pueden satisfacer sin tener un empleo, es decir, un trabajo remunerado. Y, por otro lado, ciertos empleos no las satisfacen.

Por lo tanto, las políticas económicas de creación de empleo no deberían buscar la creación de puestos de trabajo a cualquier coste. Primero, porque un empleo no siempre es la única opción para garantizar unos recursos materiales mínimos y libertad económica y, segundo, porque en ocasiones la creación de ciertos empleos puede ser perjudicial para las personas y su entorno. Esto es importante, pues actualmente el argumento de "genera puestos de trabajo" parece que sea incontestable. Pero, ¿realmente es necesario, con el fin de generar empleo, exportar armas a países que no respetan los derechos humanos, destrozar bosques y acuíferos para extraer materias primas, edificar hoteles en playas protegidas, o modificar las leyes para atraer inversores extranjeros...? En estos casos, son unos pocos los que tienen mucho que ganar, pero perdemos todos los demás. $\mathrm{Y}$, curiosamente, por lo general, los 
trabajadores tampoco salen ganando, pues lo único que consiguen son empleos precarios, temporales y mal pagados. Para ayudar a estas personas, el Estado, en lugar de favorecer la creación de estos puestos de trabajo, debe buscar otras soluciones, que las hay.

Otro medio que suele considerarse un fin en sí mismo es la reducción de la deuda pública y del déficit público. A largo plazo el mantenimiento de una deuda pública muy abultada puede ser un lastre para el Estado y, por ende, los ciudadanos. Así, el mantra económico actual, defendido especialmente por el Fondo Monetario Internacional (FMI), exige a los Estados la reducción de su deuda pública y tener un presupuesto equilibrado como un fin en sí mismo, salvo excepciones puntuales.

No obstante, en ocasiones un aumento de la deuda pública puede ser necesario y beneficioso para la economía. Efectivamente, en periodos de crisis la reducción del gasto público implica no poder realizar políticas de corte keynesiano e impacta negativamente en los servicios públicos como sanidad, la ayuda a la dependencia, la enseñanza etc. Pero es que, además, esta situación reduce drásticamente el consumo público y privado, frenando el crecimiento económico y generando desempleo. En definitiva, impacta negativamente en la calidad de vida de los ciudadanos. Una vez más, se olvida lo que debiera ser, en mi opinión, el verdadero fin, a favor de un objetivo intermedio.

\subsection{EL FACTOR AZAR}

Por otro lado, volviendo al tema azaroso del lugar de nacimiento y las características personales con las que cada uno nacemos, una forma de definir el papel del Estado podría consistir en eliminar el factor "azar", suavizar los impedimentos económicos y sociales surgidos de sucesos aleatorios: capacidad económica y cultural de la familia donde se nace, enfermedad, accidentes, desempleo. La defensa de los débiles, desprotegidos y desafortunados. No se trata, y esto es importante resaltarlo, de un enfoque desde la caridad, que es algo voluntario, sino una obligación del Estado para con sus ciudadanos. 
Así, el Estado debe facilitar en la medida de lo posible la verdadera igualdad de oportunidades, en el sentido de ofrecer a cada ciudadano el contexto adecuado a partir del cual desarrollarse como persona. De este modo, cada ciudadano, desde la libertad y un entorno favorable garantizado por el Estado, debe, a título individual y bajo su propia responsabilidad, labrarse su porvenir con su propio esfuerzo y buscar desarrollar su potencial como persona.

Estamos partiendo siempre de la premisa de que la felicidad personal, que es la máxima aspiración personal, depende de cada individuo. De que es necesario un contexto de mínimos sociales y económicos que, una vez alcanzados, dejan toda la responsabilidad en manos de cada persona.

Pues bien, dentro de esta visión, existe un umbral mínimo de bienestar económico que el Estado debe proteger. $\mathrm{Y}$, en esta línea de pensamiento, también existirá un umbral a partir del cual el hecho de acumular riqueza no tiene que ser necesariamente positivo. En este sentido, parece que hay cierto consenso en que la acumulación individual de riqueza a partir de ciertas cantidades no implica más felicidad, no favorece el desarrollo personal. Nos podemos parar a pensar en qué es lo que hace que seamos felices y si es o no es necesario disponer de grandes sumas de dinero para conseguirlo. Aquí debemos ponderar la problemática de la saturación. Por ejemplo, a un niño le puede hacer mucha ilusión ir al cine, si no va habitualmente. Pero si va todos los días, digamos que la felicidad que le reporta cae en picado. Por otro lado, podemos pensar en personas multimillonarias que llevan vidas bastante desdichadas. Y eso que lo que suele trascender de estas personas va normalmente acompañado de un aura de glamour, mostrando unas vidas perfectas y maravillosas. La acumulación de riqueza no es, en absoluto, garantía de felicidad personal.

\subsection{RIQUEZA Y FELICIDAD}

Esta forma de entender la labor del Estado tiene unas implicaciones muy profundas, pues pone sobre la mesa que la redistribución de la riqueza no tiene 
que ser tan negativa para las personas ricas, si lo que primamos no es la acumulación de riqueza y poder (que siempre es a costa de los demás, a partir de cierto umbral), sino la búsqueda personal de la felicidad. El hecho de que el Estado recaude más dinero de las personas más acaudaladas no les pone trabas para que puedan desarrollarse como personas. Incluso en algunas religiones, como el cristianismo, se ve con buenos ojos que los ricos compartan sus riquezas con los demás. No obstante, es lógico que las personas ricas no estén conformes con el reparto de la riqueza. Incluso aunque no la hayan conseguido gracias a su esfuerzo personal y sea heredada o gracias a contactos políticos, como ocurre en no pocos casos, dentro y fuera de nuestras fronteras. Las personas percibimos con mayor intensidad una pequeña pérdida que una ganancia mayor, por lo que tememos mucho sufrir pérdidas y nunca obtenemos suficiente satisfacción, por mucho que ganemos. Además, en no pocas ocasiones lo que produce placer es el mero hecho de ganar dinero y acumular poder. Y ganar dinero es más fácil cuanto más patrimonio y, consecuentemente, más poder económico se posee.

Una cuestión a considerar es el impacto que pueda tener en los incentivos de las personas ricas el hecho de que tengan que compartir parte de sus ingresos o patrimonio. El ser humano se mueve por incentivos, y el crecimiento económico depende de los incentivos, principalmente económicos, pero no exclusivamente (por lo general, relacionados con la autoestima), que tengan las personas para progresar. La importancia de los incentivos, las razones que mueven a las personas a actuar, es muy grande. Por ejemplo, una de las razones que hacen que el sistema comunista no pueda prosperar es que elimina gran parte de los incentivos personales. Obviamente, las personas ricas, si se les grava más conforme vaya aumentando su riqueza, puede que pierdan las ganas de seguir invirtiendo. No obstante, este hecho no es necesariamente negativo, sino más bien positivo. La concentración de poder económico en pocas manos impide la redistribución de la riqueza y el crecimiento económico, obstaculizando la igualdad de oportunidades. Además, la concentración del poder económico amenaza la independencia del poder político, socavado los principios democráticos. 
Por otro lado, no son necesariamente los que más tienen los que más riqueza generan. Puede darse el caso contrario, que utilicen su poder para hacer lucrativos negocios millonarios con el Estado, eliminar la competencia y el mercado de competencia perfecta, recibir subvenciones y prebendas del Estado, como amnistías fiscales. En definitiva, para enriquecerse aún más a costa del Estado, del resto de ciudadanos. Se pone en práctica una redistribución "al revés", en la que el dinero fluye de los que menos tienen a los que tienen más.

En un sistema como el español, todos debemos contribuir al sostenimiento de los gastos del Estado. $\mathrm{Y}$, en principio, lo hacemos en función de nuestra capacidad económica, si bien en el caso español actual, son los asalariados los que acaban contribuyendo más. Así que, aunque los que tienen más deberían contribuir más, en términos absolutos y relativos, lo cierto es que esto no es así. En términos relativos, los que más tienen aportan menos a la causa común, incluso actuando dentro de la ley, lo cual no parece que sea muy justo. $Y$ las diferencias, en términos relativos, no son pequeñas precisamente. En otros países, como EEUU, directamente aportan menos incluso en términos absolutos.

En cualquier caso, con independencia de que un Estado deba tener un sistema tributario realmente progresivo, lo más importante es evitar la concentración excesiva de poder económico. Que es precisamente lo que ocurre cuando los que ingresan más son los que menos aportan al erario público. Así, por ejemplo en EEUU el tipo marginal del impuesto sobre la renta, hasta el mandato de Kennedy llegó al 90\%. Claro, un factor fundamental es determinar a partir de qué cantidad. En el caso americano, parece ser que solo lo pagaba una persona: Rockefeller.

Otro tema a considerar es la fiscalidad de los rendimientos del capital. En España (año 2019), por ejemplo, el tipo marginal en el impuesto sobre la renta es del $45 \%$ en el caso de las rentas del trabajo, frente al $28 \%$ en el caso de las rentas de capital, que son, por ejemplo, los ingresos por dividendos. Y, por supuesto, está el tema de la tributación del patrimonio. El verdadero poder económico no lo otorga lo que se gane en un año, sino el patrimonio que se acumula y gestiona. 
Otra cuestión es definir quiénes son esos acaudalados a los que hacemos referencia. En este sentido, francamente, no considero que un asalariado o empresario que en España gane 100.000 euros brutos anuales y mantenga a una familia esté acumulando un poder económico excesivo que haga peligrar la independencia del Estado y pueda influir en sus decisiones.

Además, y en cualquier caso, se debe respetar siempre, salvo situaciones de emergencia, el derecho a la propiedad privada y no se puede permitir que el sistema tributario tenga carácter confiscatorio.

Las ideas que se acaban de exponer pueden sonar extrañas, incluso revolucionarias. Normalmente no somos conscientes de la gran acumulación de poder que hay en unas pocas manos en casi todos los países. España no es una excepción. Además, recientemente esa concentración del poder se está acelerando. $Y$ esos poderes fácticos, como hemos dicho, pueden utilizar al Estado para redistribuir la riqueza, pero en sentido contrario: de los que menos tienen, a los que tienen más, muchísimo más.

Esta concentración de poder es nefasta para el crecimiento económico y para el bienestar general de la población, y acaba haciendo peligrar la propia democracia. E incluso está provocando un cataclismo ecológico mundial de proporciones inimaginables.

Por otro lado, estas personas multimillonarias apenas son conscientes de los problemas comunes de sus conciudadanos y, en no pocas ocasiones, no sienten ni empatía ni compasión. Realmente, no hace falta hacer conjeturas a este respecto. Basta mirar lo que ocurre en otros países donde manda una oligarquía o mirar atrás en el tiempo. Como cuenta el botánico Cabanilles, sacerdote a las órdenes de la influyente Casa del Infantado, nada sospechoso de pensamientos revolucionarios, a finales del siglo XVIII, los hacendados residentes en Madrid no permitían que sus siervos de pequeñas pedanías de Morella, en la actual provincia de Castellón, cogieran leña de sus bosques para calentarse en invierno. $Y$ en Morella hace mucho frío en invierno. Esta actuación, que no se puede justificar de ninguna manera, muestra lo que ocurre cuando son unos pocos los que concentran todo el poder. Solo es un ejemplo entre tantos y tantos otros. Basta echar un vistazo en la literatura para encontrar más ejemplos, incluso más recientes, como en la obra de Delibes. 
Si en España nos hemos alejado de estas situaciones de pesadilla y nos parecen impensables es, precisamente, porque la concentración de poder se ha diluido. El Estado democrático ha supuesto un indudable y decidido paso adelante, trayendo consigo innumerables avances, pero el poder económico en España, y en otras democracias, aún está mucho más concentrado de lo que pensamos e influye tenazmente en las políticas del Estado. Además, no debemos olvidar que la involución siempre es posible, que los avances conseguidos pueden desaparecer si no se actúa en su defensa y que las personas más poderosas están constantemente presionando en diferentes frentes, incansables, para aumentar aún más su poder.

\subsection{CONTEXTO FAVORABLE E IGUALDAD DE OPORTUNIDADES}

¿Qué contexto económico debe garantizar el Estado y cómo? Este contexto económico repercute necesariamente en el contexto social, puesto que economía y sociedad no pueden disociarse.

Se trata de generar una sociedad con igualdad de oportunidades.

Esto no implica una sociedad igualitaria en el sentido de que todos tengan el mismo patrimonio, pero todos deben partir de, al menos, una situación de mínimos en términos de bienestar económico y acceso a ciertos servicios básicos como la educación y la sanidad.

Obviamente habrá personas mucho más ricas que otras (pero no muchísimo más ricas), pero esta situación, en sí misma, no debe ser un problema, tan solo en la medida en la que la concentración de poder económico afecte negativamente a la función del Estado de garantizar este contexto económico y social a los ciudadanos. Del mismo modo, si el Estado se extralimita en sus funciones y limita la libertad de las personas de manera que les impidiera el desarrollo personal, tal y como ocurría de facto, por ejemplo, en los Estados fascistas y comunistas, ese Estado, en mi opinión, debe modificar su forma de actuar. 


\subsection{LAS ÁREAS DE INTERVENCIÓN DEL ESTADO EN LA ECONOMÍA}

¿Cómo pueden actuar los Estados para alcanzar sus objetivos? Básicamente, y siguiendo a Musgrave, podemos identificar tres grandes áreas de intervención estatal en la economía: la estabilización económica, la redistribución de la renta y la asignación de recursos. Estas tres grandes áreas están interrelacionadas, pero se suelen estudiar por separado para facilitar la comprensión de una materia de gran magnitud.

La estabilización económica implica la definición e implementación de la política monetaria, la política fiscal y la gestión de la balanza de pagos. En la actualidad, algunos países como España han cedido parte de su soberanía nacional a favor de organismos supranacionales, por lo que ya no pueden decidir por sí mismos algunos aspectos de las políticas de estabilización económica. Así, la política monetaria, la que determina los tipos de interés de la economía y se encarga del control de la inflación, le corresponde al Banco Central Europeo. La gestión de la balanza de pagos también resulta difícil, pues es el Banco Central Europeo quien tiene capacidad para influir en el tipo de cambio del Euro. Además, la Unión Europea, así como diversos acuerdos internacionales, prohíben el empleo de instrumentos para controlar e impedir el flujo de bienes y servicios y el flujo de capitales a través de nuestras fronteras. Así las cosas, la principal medida de estabilización económica en manos del Gobierno de España es la política fiscal, la gestión del déficit público y la deuda, si bien con muchas restricciones por parte de la Unión Europea y el Fondo Monetario Internacional.

La redistribución de la renta y la riqueza (más allá de la silenciada redistribución generada por la política monetaria) tiene principalmente dos vertientes: por la parte de los ingresos y por la parte de los gastos. En cuanto a los ingresos, se encuentra el diseño del sistema tributario, los tipos de impuestos y su gestión, que tiene un impacto redistributivo en cuanto define quién debe financiar los gastos. Tampoco en este caso el Estado español puede actuar con completa 
libertad, pues la libre circulación de capitales y la existencia de paraísos fiscales en el seno de la Unión Europea, como Luxemburgo y Holanda, dificultan la gestión de determinados impuestos. En cuanto a los gastos, se trata de definir las prestaciones y coberturas sociales, tales como la existencia de rentas mínimas, pensiones o seguro de desempleo. Pero hay otros muchos factores que influyen en la redistribución de la renta, desde el mercado laboral hasta el sistema educativo. Una vez más, es necesario comentar que el Estado español, al pertenecer a la Unión Económica y Monetaria, tiene restringida la cuantía y la gestión del gasto público, por ejemplo debido a las condiciones del Pacto de Estabilidad y Crecimiento.

La asignación de recursos se puede realizar por vía presupuestaria o extrapresupuestaria. La vía presupuestaria incluye la financiación y provisión, directa o indirecta, de ciertos bienes como la seguridad nacional, sanidad, educación, vivienda, política industrial etc. Se trata de algunas de las grandes partidas de gasto estatales, junto con las derivadas de la redistribución de la renta. La vía extrapresupuestaria consume muchos menos recursos económicos y se centra en la regulación de la actividad económica y la defensa y promoción de la competencia empresarial.

Como analizaremos más adelante, la intervención estatal en la redistribución de la renta y la estabilización económica se justifica por fallos en los mercados de competencia perfecta. Estos fallos, así como la inexistencia de mercados perfectamente competitivos, justifican igualmente la intervención estatal en la asignación de recursos en algunas ocasiones.

\subsection{EL PAPEL DEL ESTADO EN LA CONSTITUCIÓN ESPAÑOLA}

Llegados a este punto es interesante recordar qué es lo que establece la Constitución española de 1978 en cuanto al papel del Estado, tanto como garante de derechos y libertades de las personas, como los principios sobre los 
que se sustenta su intervención en la economía. Así, la Constitución española (CE) se encarga de definir un Estado cuya función es la de ofrecer un contexto social y económico en el que los ciudadanos puedan desarrollarse como personas, si bien no se expresa exactamente en estos términos. El art. 10 señala que "la dignidad de la persona, los derechos inviolables que le son inherentes, el desarrollo de la personalidad, el respeto a la ley y a los derechos de los demás son fundamento del orden político y de la paz social". Resulta especialmente relevante el Título primero de la Constitución, "de los derechos y deberes fundamentales".

En cuanto a los derechos fundamentales y libertades públicas de los ciudadanos, la Constitución enuncia, entre otros: la libertad religiosa, derecho a la libertad y la seguridad, el derecho al honor, a la intimidad y la inviolabilidad del domicilio, libertad de residencia, libertad de expresión y derecho de reunión, derecho de asociación, derecho a participar en los asuntos públicos, derecho a la educación, siendo la enseñanza básica obligatoria y gratuita, derecho de sindicación y huelga etc.

En lo que respecta a los derechos y deberes de los ciudadanos en el ámbito económico, la Constitución trata temas como el sistema tributario, el mercado laboral y la organización económica del Estado. Así:

"Todos deben contribuir al sostenimiento de los gastos públicos de acuerdo con su capacidad económica mediante un sistema tributario justo inspirado en los principios de igualdad y progresividad que, en ningún caso, tendrá alcance confiscatorio" (art. 31.1 CE).

"Todos los españoles tienen el deber de trabajar y el derecho al trabajo, a la libre elección de profesión u oficio, a la promoción a través del trabajo y a una remuneración suficiente para satisfacer sus necesidades y las de su familia, sin que en ningún caso pueda hacerse discriminación por razón de sexo" (art. 35.1 CE)

"La ley garantizará el derecho a la negociación colectiva laboral entre los representantes de los trabajadores y empresarios" (art. 37.1 CE)

Se reconoce la libertad de empresa en el marco de la economía de mercado. "Los poderes públicos garantizan y protegen su ejercicio y la defensa de la 
productividad, de acuerdo con las exigencias de la economía general y, en su caso, de la planificación" (art. 38 CE)

Finalmente, el papel del Estado en la política social y económica viene definido por diversos principios, entre los que destacarían:

La protección social, económica y jurídica de la familia.

El progreso social y económico y una distribución de la renta regional y personal más equitativa, en el marco de una política de estabilidad económica, y una política orientada al pleno empleo.

Un régimen público de Seguridad Social para todos los ciudadanos que garantice la asistencia y prestaciones sociales suficientes ante situaciones de necesidad, especialmente en caso de desempleo, siendo libres la asistencia y prestaciones complementarias.

Derecho a la protección de la salud, siendo competencia de los poderes públicos organizar y tutelar la salud pública.

Promoción y derecho a la cultura, así como la promoción pública de la ciencia y la investigación en beneficio del interés general.

Derecho a un medio ambiente adecuado para el desarrollo de la persona.

Derecho a disfrutar de una vivienda digna y adecuada, regulándose la utilización del suelo de acuerdo con el interés general para impedir la especulación.

Política de previsión, tratamiento, rehabilitación e integración de disminuidos físicos, sensoriales y psíquicos.

Pensiones adecuadas y periódicamente actualizadas para garantizar la suficiencia económica a los ciudadanos durante la tercera edad, junto con servicios sociales que atenderán a problemas específicos de salud, vivienda, cultura y ocio.

Defensa de los consumidores y usuarios, protegiendo su seguridad, salud y legítimos intereses económicos.

Por otro lado, el Título octavo, "Economía y Hacienda", señala que toda la riqueza del país en sus distintas formas y sea cual fuere su titularidad está subordinada al interés general. Además, se reconoce la iniciativa pública en la actividad económica, la posibilidad de reservar al sector público recursos o servicios esenciales, especialmente en caso de monopolio y asimismo acordar 
la intervención de empresas cuando así lo exigiere el interés general. El Estado puede planificar la actividad económica general para atender a las necesidades colectivas, equilibrar y armonizar el desarrollo regional y sectorial y estimular el crecimiento de la renta y la riqueza y su más justa distribución. Además, los bienes de dominio público y los bienes comunales deben regularse inspirándose en los principios de inalienabilidad, imprescriptibilidad e inembargabilidad, así como su desafectación.

En definitiva, son muy numerosas las vías a través de las cuales el Estado español incide en la actividad económica y social de nuestro país, tal y como se desprende igualmente de la lectura de los artículos 148 y 149 de la Constitución, que tratan de las competencias del Estado y las Comunidades Autónomas.

Efectivamente, podemos comprobar cómo la Constitución española de 1978 defiende una participación amplia del Estado. Así, son numerosos los derechos y libertades personales que debe garantizar. Por otro lado, el Estado participa en diversos ámbitos de la economía, tales como la sanidad, la educación, la defensa del medioambiente etc. En los capítulos venideros veremos en qué se justifica la intervención del Estado en estos ámbitos.

No obstante, es fácil constatar cómo algunos de los derechos enunciados están lejos de ser una realidad para muchos españoles. De hecho, en numerosas ocasiones se aprecia cierto olvido por parte del Gobierno de turno en cuanto a lo que respecta a la defensa de ciertos derechos, que parecen ser de segunda categoría, como el derecho a la vivienda. En este caso, por ejemplo, se podría alegar que solo se puede garantizar asumiendo el Estado un coste muy elevado. Pero, claro, teniendo en cuenta el enorme número de viviendas vacías en manos de los bancos rescatados por el Estado y que ahora pertenecen al Estado, esta argumentación pierde peso. Por no hablar de la posible implementación de políticas que fomentaran el alquiler de pisos dando suficiente protección a los propietarios.

El derecho a disfrutar de un medio ambiente adecuado también es vapuleado constantemente, en pro de otros intereses poco confesables que favorecen a ciertos grupos de presión. 
Generalmente, para justificar esta situación, se argumenta que estos derechos no son verdaderos derechos en el sentido de que, según el artículo 53 de la Constitución, se trata realmente de principios que deben ser tenidos en cuenta por los poderes públicos, el Estado, pero que no pueden ser alegados directamente ante la Jurisdicción ordinaria, es decir, no se reconocen como derechos que puedan ser defendidos en los Tribunales.

Finalmente, es paradigmática la segunda y última reforma que ha sufrido la Constitución. Tuvo lugar en el año 2011, bajo el Gobierno socialista y modificó el artículo 135 para incluir el derecho preferente de los inversores para cobrar la deuda adquirida al Estado español. Así, desde 2011, es más importante garantizar los derechos de los inversores, el denominado servicio de la deuda, que goza de prioridad absoluta, que el derecho de pensionistas, desempleados, enfermos etc. Ciertamente, esta reforma no encaja muy bien con el modelo de Estado que se defiende en este ensayo ni el modelo de sociedad que defiende la propia Constitución en su articulado previo. 



\section{FUNCIONES ECONÓMICAS ELEMENTALES DEL ESTADO}

En los siguientes capítulos vamos a tratar la justificación y las formas de intervención del Estado en la economía y su impacto social a partir del análisis de los fallos del mercado.

Pero, en primer lugar, vamos a comentar dos funciones que debe desarrollar el Estado sobre las que existe un consenso razonablemente amplio y que son requisito necesario para la propia existencia del Estado: la defensa nacional y la seguridad ciudadana. Desde el punto de vista económico, se trata de bienes públicos puros, lo que justifica que sea el Estado quien se encargue de proporcionarlos.

Estas dos funciones son realizadas por todos los Estados, a lo largo de toda la historia. Si un Estado no puede garantizar su integridad territorial, ni el orden público dentro de sus fronteras ni puede garantizar el cumplimiento de sus normas, no es un Estado, es un territorio donde impera el caos.

En los Estados absolutistas y dictatoriales, éstas eran las principales funciones del Estado, que garantizaban que el statu quo se perpetuara, defendiendo a las castas dominantes frente a ataques extranjeros y frente a insurrecciones internas, aplicando el monopolio de la violencia contra la población desarmada sin ningún tipo de rubor. En la historia encontramos innumerables en este sentido, desde Justiniano en el siglo VI a los recientes conflictos en Colombia durante el verano de 2021.

Dentro de las corrientes económicas más liberales, el Estado debería limitarse a realizar estas dos funciones, dejando el resto a la iniciativa privada.

Es razonable pensar que un Estado no puede delegar en manos privadas la defensa nacional, pues se produciría una gran concentración de poder en manos de las empresas o particulares que ostentaran dicha función. Por este motivo, en las monarquías absolutas, el rey era el jefe supremo del ejército. Solo cuando el poder de los monarcas se fue debilitando se vieron obligados a ceder ese poder 
a otros estamentos del Estado. En España, por cierto, el Rey sigue siendo el Jefe de las Fuerzas Armadas.

No obstante, existen diferencias en cuanto a la manera en la que el Estado debe realizar su cometido concretamente. Así, frente a opiniones que defienden que es el Estado el que debe encargarse directamente del ejército y la policía, cada vez es más frecuente observar que el Estado subcontrata algunas de estas actividades, recurriendo a empresas privadas de seguridad o a empresas privadas de armamento, algo similar a lo que ocurría en el siglo XVII en Europa, cuando los Estados recurrían a mercenarios. Estas opciones, en aras de la eficiencia, conllevan riesgos evidentes, cual es dejar la seguridad nacional en manos privadas que no se rigen por el interés general sino por el beneficio económico particular y que pueden tener incentivos ocultos para maximizar sus beneficios.

En cualquier caso, la actuación del Estado en estos ámbitos también se justifica por fallos en los mercados, que hacen que la opción estatal sea la más eficaz y eficiente.

\subsection{LA DEFENSA NACIONAL}

Probablemente, el primer papel de un Estado sea proteger la integridad territorial frente a ataques e invasiones de terceros países. Porque si se construye una sociedad donde las personas viven con unos estándares de vida relativamente elevados, tanto en términos económicos como de libertades personales, una de las prioridades de la población es defender ese status frente a amenazas internas y externas. Igualmente, aunque se trate de una sociedad absolutamente desigual e injusta, las oligarquías que ostenten el poder también querrán defenderlo frente a injerencias internas y externas.

La amenaza externa más grave es la invasión por fuerzas extranjeras, la ocupación del territorio y la anexión del mismo, con la subsiguiente pérdida de soberanía. Aunque los países de Europa occidental no nos sintamos 
amenazados por ninguna potencia exterior que tenga ánimo de invadir nuestro territorio, no debemos olvidar que las guerras entre países han sido y siguen siendo una realidad tristemente habitual.

Llegados a este punto, resulta interesante analizar qué es lo que motiva las guerras. Muchas veces, debajo de las motivaciones, digamos, oficiales, se encuentran otras causas ocultas que son las que en realidad motivan a los dirigentes que toman la decisión de ir a la guerra, si bien parte de la población afectada por la guerra sí que cree realmente los argumentos "oficiales". Así, bajo argumentos patriotas y religiosos en no pocas ocasiones se esconden razones económicas y de poder personal. La historia está llena de ejemplos.

En el pasado, las conquistas territoriales eran fundamentales para aumentar la riqueza del monarca, puesto que ésta dependía básicamente de la tierra cultivable y las materias primas en su territorio, y de la mano de obra disponible para trabajarlas. Éstos eran los factores productivos por excelencia, por lo que las guerras eran necesarias y casi la única opción, para poder acceder a ellos. Obviamente, los siervos que trabajaban la tierra no obtenían ninguna ganancia con las guerras, pues su calidad de vida no iba a mejorar, pero se les intentaba convencer de la bondad de las guerras remitiendo a conceptos abstractos como la grandeza de la patria o la defensa de la religión. En la época colonial, la situación no fue muy diferente, y, al tiempo que se conseguían materias primas baratas, las metrópolis coloniales conseguían mercados para sus empresas manufactureras, en las que trabajaban en condiciones deplorables obreros mal pagados.

Actualmente, el crecimiento económico de los países se debe aún en parte a la disponibilidad en su territorio de tierra cultivable y materias primas. Esto es especialmente cierto en el caso de ciertos países que obtienen su riqueza de la exportación de materias primas, como Arabia Saudí, Noruega, Sudáfrica, Chile o Australia. No obstante, debemos recordar que muchos otros países ricos en materias primas se ven afectados por guerras civiles o inestabilidad política que hacen que no puedan obtener rédito de sus riquezas naturales, es decir, que la mayor parte de la población se beneficie de esa riqueza, riqueza que sí queda en parte en manos de la oligarquía local dominante y multinacionales extranjeras. En cualquier caso, hoy en día el crecimiento económico de los países 
industrializados no se debe ni a la tierra, ni a las materias primas, sino a la tecnología. Por otra parte, en la actualidad el comercio internacional resulta igualmente fundamental. Por lo tanto, las motivaciones que impulsan a los Estados a ir a la guerra han cambiado. También el objetivo final, que ya no es necesariamente la expansión territorial, per se, sino el control de ciertos enclaves estratégicos o de ciertos recursos naturales.

Desde esta perspectiva, ¿debe España temer una invasión? ¿de qué país? Si partimos de la base de que, en última estancia, las guerras se deben a intereses económicos y ansias de poder por parte de los dirigentes nacionales, habría que preguntarse qué se puede ganar invadiendo España. Desde luego, recursos naturales no (salvo energía solar, tal vez). Ese fue tal vez el caso de la pérdida territorial más reciente, el Sahara, rico en fosfatos y otros recursos naturales Como enclave estratégico el papel de España también es muy limitado actualmente, puesto que no está en las rutas principales de los gasoductos y oleoductos ni cerca de zonas de conflicto bélico. Por lo tanto, a corto plazo no es de esperar invasión alguna. Además, España forma parte de la OTAN y de la Unión Europea, lo que hace que, por un lado, la invasión por parte de países de Europa occidental y EEUU se pueda descartar y, por otro, que en caso de conflicto bélico se pueda contar con el apoyo de otros Estados con gran poder armamentístico. Además, los países con capacidad bélica suficiente para suponer un problema son socios económicos importantes del bloque aliado de España y una guerra tendría enormes costes económicos para ambas partes, sin que los beneficios esperados los compensasen.

No obstante, la situación actual no tiene por qué mantenerse indefinidamente, por desgracia. Acontecimientos inesperados pueden suceder. $Y$ la historia nos recuerda que nada es inmutable. Cambios sociales o tecnológicos o el cambio climático pueden hacer que la situación actual se modifique profundamente. Por lo tanto, resulta indispensable contar con unas Fuerzas Armadas capaces de defender el territorio en caso de un ataque extranjero. Recordemos que, en última instancia, la mera existencia del Estado español depende de ello. Además, el Estado, lógicamente, ha adquirido una serie de obligaciones para con los países aliados que debe cumplir. 
Lo expuesto hasta ahora no se debe entender como una carta blanca para que el Gobierno de turno gaste indiscriminadamente en presupuesto militar. Una vez se ha identificado que es responsabilidad del Estado encargarse de la defensa del territorio, ya depende de las diferentes opciones políticas definir cómo se implementa esta defensa en términos de efectividad y eficiencia, y siempre desde la transparencia y el escrutinio público. Por desgracia, el ejército español está plagado de casos de corrupción que no son perseguidos y que no solo cuestan al erario público cantidades ingentes de dinero, sino también vidas humanas y que son ocultados por los principales medios de comunicación sin que los partidos políticos tomen medidas correctoras. En este sentido, es imprescindible leer la obra del exteniente Gonzalo Segura, especialmente "EI Libro Negro del Ejército Español".

En definitiva, para que exista un Estado se necesita un territorio y una población y por tanto hay que defender tanto el territorio como a la población de potenciales ataques bélicos. Este es posiblemente el principal papel que han asumido históricamente los Estados, con independencia de la forma de Estado, desde Sumer y Egipto, pasando por Grecia y el Imperio Romano hasta nuestros días: la integridad territorial. El que el Estado se haya implicado en el bienestar de la población ya es otra cuestión, muchísimo más reciente.

\subsection{FUERZAS Y CUERPOS DE SEGURIDAD DEL ESTADO}

Un logro de enorme importancia en España es la seguridad ciudadana. Poder caminar por la calle, incluso por la noche, sin temer por la propia vida y sin miedo a que te atraquen. Obviamente, existen lugares más peligrosos que otros. $Y$, desgraciadamente, la situación no es la misma para hombres y para mujeres. Pero es indudable que la situación en España es mejor que la que había hace 40 años e infinitamente mejor que la de muchos países en los que salir a la calle a ciertas horas te puede costar el dinero y la vida. 
Pensemos en tantos países, por ejemplo africanos, centroamericanos o de Oriente Medio, donde la población vive con el miedo diario a que entren en sus casas personas armadas y les roben sus escasas pertenencias necesarias para su subsistencia. O, por hablar de las mujeres, que directamente las golpeen, las rapten, las violen o las maten. Es lógico que muchas personas intenten escapar de estas sociedades en las que en realidad falta un Estado como tal, pues no es ni tan siquiera capaz de garantizar la seguridad física.

En esta misma línea, la protección de la propiedad privada resulta también fundamental para garantizar la calidad de vida de la población y el crecimiento económico. $\mathrm{Y}$ es que, sin tener garantizada la seguridad personal, el derecho a la vida y la propiedad particular, se genera una inestabilidad enorme que afecta indudablemente a la calidad de vida de las personas, en términos físicos y psicológicos, y, por ende, al crecimiento económico. Por otro lado, ese crecimiento económico, cuando se distribuye entre toda la población, genera sociedades menos violentas, pues en no pocos casos la violencia extrema surge como única vía de escape ante una situación vital devastada, sumida en la desesperación y sin expectativas de futuro.

En España, las Fuerzas y Cuerpos de Seguridad del Estado, la Policía Nacional y la Guardia Civil, son las que se encargan en primer término de velar por nuestra seguridad. Debido a la cesión de competencias a algunas Comunidades Autónomas, ciertas atribuciones son realizadas por la Ertzaina en el País Vasco y por los Mossos d'Escruada en Cataluña. A nivel municipal, es conveniente destacar que la Policía Local tiene competencias diferentes, aunque puede colaborar con estos otros Cuerpos.

Al ser la española una sociedad compleja, la actividad que realizan los Cuerpos de Seguridad de prevención y erradicación del crimen abarca muy diversos ámbitos y no se centra solo en la persecución de crímenes violentos y el terrorismo, sino también en la lucha contra actividades ilícitas que afectan de manera muy negativa a la sociedad en su conjunto, como el crimen organizado, la corrupción o la evasión fiscal.

Desgraciadamente, la actuación de los Cuerpos y Fuerzas de Seguridad no siempre es ejemplar. Ciertos comportamientos aislados que desgraciadamente 
no son perseguidos con la firmeza que debieran, leyes que otorgan capacidades arbitrarias muy discutidas y mal utilizadas por algunos agentes del orden, órdenes de los superiores para emplear la violencia indiscriminada contra los ciudadanos en casos controvertidos, tramas corruptas, uso partidista para eliminar contrincantes políticos y socavar la democracia etc., enturbian en ocasiones la gran labor policial.

Pero, siendo esto cierto, no se debe olvidar la ingente tarea que realizan muchos agentes en temas como la lucha contra la corrupción y garantizando la seguridad ciudadana, por ejemplo, a pesar de sufrir constantes amenazas y peligros. Obviamente, en un colectivo formado por miles de personas, se pueden encontrar toda clase de comportamientos y no se puede juzgar al colectivo por comportamientos aislados.

Finalmente, como toda actuación estatal, debe estar sujeta a controles transparentes por parte de la ciudadanía para verificar si se alcanzan los objetivos definidos y de qué manera.

\subsection{IMPORTANCIA DE UN TERRITORIO HABITABLE}

La existencia de un Estado exige necesariamente un territorio y una población. Ya hemos comentado cómo una de las causas más comunes de las guerras del pasado era ampliar el territorio y, de esta manera, también la población de los Estados. Además de la mera existencia de un territorio, sus características en términos de recursos naturales son determinantes para su desarrollo. Así, y en primer lugar, el territorio debe garantizar la supervivencia de la población, es decir, debe tener suficientes recursos naturales para alimentar y permitir el desarrollo económico de las personas que viven en él. Para que prospere la vida debe haber aire limpio, agua potable, tierra cultivable, un clima que permita la agricultura y la ganadería etc. Las características de la flora y la fauna también determinarán el grado de desarrollo cultural, social y económico que puede alcanzar el Estado afincado en el territorio, así como la existencia de recursos minerales. Para una reflexión sobre cómo el contexto geográfico y ambiental 
influye en el desarrollo de las civilizaciones recomiendo el libro y el documental "Armas, Gérmenes y Acero" de Diamond.

Si bien no se suele incluir el cuidado del medio ambiente entre las funciones fundamentales, básicas e indiscutibles del Estado, esta función está igualmente ligada a su propia existencia. Cambios medioambientales han sido los causantes de la desaparición de Estados, de grandes movimientos migratorios y han influido de forma decisiva en la historia de la humanidad. Antiguamente, estos cambios medioambientales se debían a catástrofes naturales como la erupción de volcanes, sequías prolongadas o la aparición de plagas sobre los que el ser humano no tenía ninguna capacidad de control. Pero en las últimas décadas el ser humano, como consecuencia de su evolución tecnológica y su actividad económica puede, con su acción, deteriorar rápidamente el medioambiente con efectos devastadores para su propia supervivencia. $Y$ eso es precisamente lo que está ocurriendo. Frenar y revertir esta situación solo es posible si los Estados, aisladamente y de forma coordinada, actúan decididamente y con rapidez. A nivel local, el deterioro del medio ambiente resulta palpable con ejemplos como la contaminación del aire y el agua, la pérdida de suelo cultivable, pérdida de biodiversidad, contaminación por plásticos y un largo etcétera. A nivel global, la principal amenaza es el cambio climático por la emisión de gases de efecto invernadero.

En el momento de escribir estas líneas, aún existen negacionistas del cambio climático, al igual que personas que creen en el creacionismo o que la Tierra es plana. El negacionismo más extremo niega directamente que haya un cambio climático. El más moderado niega que el cambio climático se deba a la acción del ser humano. Es posible que algunos de los negacionistas sean realmente sinceros. Pero tampoco cabe descartar que muchos de ellos se hayan autoconvencido por los profundos cambios sociales y económicos que conlleva reconocer la gravedad y urgencia del problema. Un problema de vida o muerte para muchos millones de personas del que apenas se habla en los medios de comunicación. $\mathrm{Y}$ es que parar el cambio climático implica poner patas arriba la sociedad actual y sus pautas de consumo, nuestro sistema productivo y, por ende, el statu quo, las relaciones de poder, por lo que no son pocos los grupos de presión que obstaculizan cualquier propuesta de cambio. 
El cambio climático es una realidad. No es necesario ser un científico de los que analizan las capas de hielo en Groenlandia y la Antártida y estudian la evolución del clima en la Tierra a lo largo de centenares de miles de años para saber que esto es así. Por cierto, es importante destacar que se conoce con mucho detalle la historia climática del planeta en los últimos 800.000 años y que en todo este periodo nunca hasta ahora se habían alcanzado los niveles de CO2 actuales. Las consecuencias exactas del cambio climático son muy difíciles de prever en muchos casos, pero cualquier cambio puede ser muy peligroso para la especie humana y toda la vida del planeta que ha evolucionado para adaptarse perfectamente a unas condiciones climáticas que están mutando rápidamente. Se está rompiendo un equilibrio en el que participan una enorme cantidad de factores y nos adentramos en un periodo de gran incertidumbre. Lo que sí sabemos es que, a nivel mundial, están aumentando las olas de calor y los incendios, las sequías y las inundaciones, los huracanes... Aparecen plagas devastadoras. Desaparecen ecosistemas enteros y se reduce la biodiversidad, lo cual, según algunos expertos, puede ser el causante de la aparición de nuevos virus y pandemias. Desaparece tierra fértil y sube el nivel del mar, amenazando el territorio donde viven millones de personas y el suministro de alimentos de millones de personas.

Lo más dramático es que todo apunta a que la situación está empeorando rapidísimamente y va a seguir acelerándose aún más a medida en que aumentan las emisiones de $\mathrm{CO} 2$ y metano, los principales gases de efecto invernadero, como consecuencia de la actividad humana, conforme salga a la atmósfera el metano que se encuentra capturado por el permafrost y en el suelo oceánico, los polos se sigan descongelando y los océanos se acaben de saturar de CO2. Dada la inmensa magnitud del problema, que no es otro que el grave peligro para la supervivencia de miles de millones de personas y otros seres vivos y el cambio radical del planeta que hemos conocido hasta ahora, el cambio climático debiera abrir diariamente todos los telediarios del mundo, pero no es así. $Y$ cabe preguntarse por qué.

Solo la acción de los Estados a nivel particular y de forma colectiva puede salvarnos de la catástrofe. La propia subsistencia de los Estados está en juego. Las actuaciones para frenar las emisiones de gases de efecto invernadero pueden ser muy costosas, especialmente para algunos sectores económicos y 
pueden requerir cambios en el estilo de vida occidental. Pero no actuar conlleva cambios mucho mayores y muchísimo más drásticos, incluso en el plazo de un par de décadas. De hecho, los costes de no actuar son inconmensurables y ya están aquí: huracanes, incendios, inundaciones, sequías, plagas, hambrunas... enormes costes en términos humanos y económicos. 



\section{EL MERCADO DE COMPETENCIA PERFECTA.}

Una vez tenemos un territorio habitable donde el Estado garantiza la independencia frente a intrusiones extranjeras y la seguridad personal de los ciudadanos, así como la propiedad privada, pilares fundamentales para el desarrollo económico y condiciones previas necesarias para un correcto funcionamiento de los mercados, veamos cómo se justifican las otras áreas de intervención del Estado en el ámbito económico.

Para ello, se va a analizar el modelo de competencia perfecta y comprobaremos cómo sus fallos justifican la participación del Estado debido a la existencia, por ejemplo, de las llamadas "externalidades". Así, el Estado debe actuar para conseguir la estabilización económica, una adecuada redistribución de la renta y la riqueza y, en algunos casos, participar en la asignación de recursos mediante la regulación y la participación directa en los mercados de bienes y servicios. Además, algunos mercados se alejan demasiado de las condiciones de los mercados de competencia perfecta, lo cual justifica una participación más intensa del Estado en la asignación de recursos.

Incluso con mercados de competencia perfecta sin presencia de externalidades, el Estado debe actuar para definir los derechos de propiedad y protegerlos. Asimismo, debe velar por el cumplimiento de los contratos y la defensa de los consumidores. Es decir, debe haber seguridad jurídica. Se trata de crear unas condiciones que son necesarias para la existencia de una verdadera economía de mercado pues se trata de definir el marco normativo, las reglas del juego, y hacerlas respetar.

En este sentido, para defender la existencia de los mercados de competencia perfecta, los Estados deben proteger especialmente a los consumidores para evitar el enriquecimiento injusto de las empresas. Como veremos a continuación, para definir el mercado de competencia perfecta no basta con establecer ciertas condiciones relativas a las empresas, sino también relacionadas con los consumidores. $Y$, además, debemos subrayar que todos los problemas que se dan en un contexto de competencia perfecta se ven multiplicados en su ausencia. Efectivamente, no es extraño encontrarse con abusos de poder de 
mercado por parte de grandes empresas, como empresas de energía o de telecomunicaciones, bancos o aerolíneas, que afectan a millones de consumidores y que el Estado debe evitar. En ocasiones, la pérdida para cada cliente es pequeña, por lo que no les compensa reclamar a título individual, lo que genera a las empresas, de forma agregada, beneficios millonarios injustos que ponen de manifiesto ineficiencias en los mercados.

\subsection{ESCUELAS DE PENSAMIENTO}

El grado de participación que debe tener el Estado en la vida de los ciudadanos o súbditos es muy discutido, con las excepciones que acabamos de comentar en el capítulo anterior.

No compete en este ensayo analizar los postulados de las diferentes corrientes políticas que, por otro lado, han ido modificando con el tiempo su contenido, por lo que conceptos como "socialismo" o "liberalismo" han visto cambiar su significado con el tiempo y se utilizan con matizaciones muy diferentes por distintos autores.

En cualquier caso, se puede resumir que hay líneas de pensamiento que defienden una participación muy intensa del Estado en el ámbito económico, prácticamente impidiendo la participación privada, mientras que otras opciones intelectuales priman la acción individual y prácticamente excluyen la actuación del Estado en la economía, confiando plenamente en el funcionamiento de los mercados.

Ya hemos comentado en el prefacio que la economía es una ciencia social, por lo que, al no disponer de laboratorios donde contrastar las teorías económicas, debemos fijarnos en la evolución histórica para analizar el impacto real de las diferentes opciones de política económica e intentar extraer conclusiones. Pues bien, el comunismo, que defendía la participación predominante del Estado y la economía planificada, se implementó de forma real en numerosos países durante gran parte del siglo $\mathrm{XX}$, por lo que se pueden extraer conclusiones acerca de sus ventajas y desventajas. 
Sin entrar a valorar las motivaciones históricas dado el contexto social y económico en el que surgió el comunismo (que en realidad son de una importancia fundamental y recomiendo al lector que se instruya al respecto), lo que no se discute es que el experimento comunista fracasó. Y presumiblemente no tanto por fallos en la teoría, sino porque la implementación de dicha teoría a la práctica no es posible. Un factor fundamental en la economía son las motivaciones personales. Si olvidamos qué es lo que mueve a las personas a actuar, sus incentivos, cualquier teoría fracasará. Según mi opinión, el comunismo, tal y como se implementó en muchos países, impedía la iniciativa particular, que es el motor de la economía. Esa iniciativa requiere un marco en el que desarrollarse que no se da en el comunismo. El otro fallo fundamental es que la teórica "dictadura del proletariado" devino en una dictadura de ciertas oligarquías que cercenaron violentamente las libertades y los derechos humanos, con la creación de una nueva clase social, la burócrata. Esta evolución, conociendo las motivaciones humanas y la estructura del Estado comunista, también era previsible. Por lo tanto, en mi opinión, no es que los valores del comunismo y las metas que busca sean erróneos, sino que implementar una sociedad comunista, siendo las personas como somos, no es factible y en poco tiempo esa sociedad se transforma en una dictadura, indefectiblemente.

Por lo tanto, en este ensayo no voy a confrontar la problemática del papel económico del Estado con la visión comunista, sino con la visión llamada neoliberal imperante en la actualidad y que debiera llamarse neomercantilista. Esta corriente aboga, en teoría, por un papel del Estado lo más reducido posible. Obviamente, existen diferentes líneas de pensamiento que matizan cuál debe ser este papel. Pero antes de dar por zanjado el tema del comunismo, cabe destacar que tras la caída de la comunista URSS en 1991, con la reducción del papel redistributivo del Estado en la Economía y la implantación acelerada del capitalismo privado, la producción del país descendió vertiginosamente, así como la calidad de vida de los ciudadanos, tal y como describe Stiglitz, en "El Malestar en la globalización" o Naomi Klein en "La Doctrina del Shock". Por otro lado, el "capitalismo de Estado", que implica que el Estado es el propietario de algunas industrias, o la "planificación estatal", que hace referencia a la intervención del Estado en organizar la producción de ciertos bienes 
determinando, por ejemplo, cómo y cuánto se deben producir, son propios del sistema comunista pero siguen siendo opciones económicas de candente actualidad. De hecho, el fantástico crecimiento de la economía china se basa en esta clase de actuaciones en algunos sectores económicos concretos, normalmente de naturaleza estratégica, junto con la creación de mercados en otros sectores.

Una vez aceptado que el control absoluto por parte del Estado de los medios de producción y la planificación completamente centralizada no son la mejor vía para alcanzar el bienestar económico de la población ni para garantizar sus derechos humanos, nos queda, básicamente, la ideología capitalista/liberal. Simplificando, podríamos decir que esta ideología postula que el Estado, mejor que no influya en la economía. La iniciativa se debe dejar a las empresas y los particulares, que son quienes, movidos por su afán de aumentar su riqueza personal, conseguirán la asignación eficiente de los recursos económicos. Esta forma de pensamiento es la que impera en la actualidad y, aunque es discutida desde diversos ámbitos, es la aceptada por numerosos partidos políticos, en España y otros países de nuestro entorno, con ciertas matizaciones.

El caso es que la teoría capitalista "pura" ya demostró estar equivocada hace muchos años, mientras surgían los primeros Estados comunistas, cuando, en el año 1929, la economía capitalista norteamericana colapsó y se entró en una tremenda recesión a nivel global que, entre otras consecuencias, espoleó la crisis en Alemania y facilitó la llegada al poder del partido nazi. Solo como consecuencia de la intervención del Gobierno de EEUU en la economía aumentando el gasto público con motivo de la Segunda Guerra Mundial se consiguió salir de la crisis, implementando políticas de corte keynesiano. Éste es otro experimento de la historia que conviene no olvidar. En la actualidad, el capitalismo puro es criticado por diversos motivos. Algunos de los más importantes son que los postulados capitalistas están directamente enfrentados con el desarrollo sostenible de la economía y la preservación del medio ambiente para generaciones futuras, así como el incremento imparable de la desigualdad y la generación de grandes fluctuaciones macroeconómicas con sus crisis económicas y financieras pertinentes que obligan a intervenir al Estado, causándole graves perjuicios. 
Por otro lado, cabe preguntarse si actualmente los que se autodenominan "capitalistas" realmente son capitalistas en el sentido estricto, es decir, reniegan absolutamente de la intervención del Estado en la economía. En mi opinión, actualmente apenas hay verdaderos defensores del capitalismo puro, sino diferentes versiones capitalistas que asignan diferentes funciones al Estado, en unos casos primando el bienestar de la población y en otros favoreciendo más el mantenimiento del statu quo, de las relaciones de poder vigentes, que son quienes se benefician de la "no regulación". Este último es en realidad un capitalismo de "amiguetes", en el que el Estado sólo debe intervenir a través de medidas, directas o indirectas, que garanticen a las grandes empresas y grandes patrimonios beneficios sustanciosos, manteniendo el statu quo y acrecentando la concentración de poder en unas pocas manos y las desigualdades sociales. Es decir, nos encontramos de nuevo con la situación que tanto criticó Adam Smith, una nueva versión del antiguo mercantilismo. Por ejemplo, mientras la economía va bien, los beneficios se mantienen en las grandes empresas, que apenas pagan impuestos, pero cuando llega la crisis, las pérdidas de las grandes empresas se socializan y el Estado acude al rescate, aun si tiene que subir impuestos a los ciudadanos, recortar prestaciones sociales y el Estado debe endeudarse. En la práctica parece que el Estado debe actuar en la economía siempre y cuando beneficie los intereses de la oligarquía que detenta el poder, para eliminar los impuestos que afectan a las grandes fortunas, asignarles dinero mediante la política monetaria, reducir la capacidad de negociación de la clase obrera, rescatar a sus empresas en apuros o que el Estado contrate con sus empresas toda clase de actividad, por citar algunos ejemplos.

En cualquier caso, al analizar el papel que el Estado debe desempeñar en la economía, la discusión gira entorno a la siguiente cuestión: ¿Acaso no son las empresas más eficientes que el Estado a la hora de proporcionar bienes y servicios a los ciudadanos? ¿Puede el Estado asignar los recursos de la economía mejor que los mercados? ¿Es necesario que el Estado intervenga para garantizar una redistribución mínima de los recursos para evitar que parte de la población caiga en la pobreza extrema? 
Pues bien, como casi todo en esta vida, la respuesta es: "depende". O al menos, así lo veo yo. En lo restante del libro vamos a reflexionar sobre en qué condiciones es mejor que el Estado no se entrometa lo más mínimo en la actividad económica y cuándo es recomendable que tome el timón. Pero no debemos olvidar que el éxito o fracaso de cada opción (intervenir o no en la economía y de qué manera) se valorará a la luz de la medida expuesta en el segundo capítulo: ¿es la mejor manera de crear unas condiciones sociales en las que las personas nos podamos desarrollar y ser felices? El centro deben ser siempre las personas.

La clave de todo este análisis es el concepto de "mercado de competencia perfecta".

\subsection{EL MERCADO DE COMPETENCIA PERFECTA}

Cuando la economía funciona en un contexto de mercados de competencia perfecta, la teoría económica tradicional, partiendo de ciertas premisas, demuestra que el "laissez fair" es la mejor política económica. Es decir, el Estado no debe intervenir, pues los agentes económicos son capaces de realizar la asignación de recursos de la manera más eficaz posible. Dicho de otra manera, en estos casos la gestión privada será siempre mejor que la gestión pública.

Esta afirmación tan rotunda y sencilla es, a mi parecer, totalmente cierta siempre y cuando se cumplan las premisas necesarias y no haya fallos en esos mercados. Esta sencillez, aunque parezca contradictorio, ha supuesto un enorme problema, pues se ha llegado a simplificar aún más, por motivos obviamente políticos, y se ha quedado en "la gestión privada será mejor siempre que la gestión pública", olvidando la introducción de "en estos casos". Así, hemos aprendido de memoria el mantra de que "lo privado funciona siempre mejor que lo público" e incluso honestamente lo creemos, teniendo la percepción sesgada, de forma que percibimos con más claridad (y nos soliviantan más) los fallos en 
el sector público que los fallos en el sector privado, que los hay, y muchos, como iremos recordando a lo largo de los próximos capítulos.

Pero, ¿qué son estos mercados de competencia perfecta? ¿Qué características tienen que los hacen tan especiales? Estas son preguntas fundamentales que es preciso responder, dado que de la existencia o no de esta competencia perfecta depende el grado de participación del Estado en la economía.

Bien, veamos un poquito de teoría. Los mercados de competencia perfecta son aquellos en los que existe un equilibrio entre todos los participantes del mercado, oferentes y demandantes, y ningún participante goza de un poder superior al de los demás que le permita sacar provecho de esa situación. Estas son algunas de sus características principales, para el ejemplo de mercados de producción de bienes:

- Existen muchas empresas oferentes en el mercado, sin que ninguna de ellas tenga una cuota de mercado significativa. Por ello, el tamaño relativo de las empresas es pequeño.

- Todas las empresas ofrecen productos idénticos sin que sea posible diferenciación alguna.

- Todas las empresas son precio-aceptantes, lo que implica que tienen que vender sus productos al precio que fije el mercado. Esto significa que todas las empresas venden los productos al mismo precio.

- Todas las empresas tienen una estructura de costes similar, es decir, ninguna empresa puede producir a un coste inferior que las demás. En términos económicos podemos decir que el coste marginal de todas las empresas es el mismo, así como su coste medio.

- Tanto empresas como clientes disponen de información perfecta y sin coste. Esto es, el mercado es perfectamente transparente. Es posible comparar los diferentes productos, todas sus características y su precio de venta.

- No existen costes de transporte ni de transacción, por lo que el comprador no incurre, por ejemplo, en costes relacionados con el tiempo dedicado a buscar al proveedor y comprobar su idoneidad y fiabilidad o la 
disponibilidad y precio de los productos, negociar y redactar el contrato de compraventa ni en costes por litigios con la empresa vendedora.

- No existen barreras de entrada ni de salida para las empresas. Es decir, si un sector resulta económicamente atractivo, nuevas empresas se pueden incorporar. Por el contrario, cuando el sector ya no sea atractivo, las empresas pueden dejar su actividad sin tener que afrontar grandes costes.

En un mercado de estas características, una vez alcanzado el punto de equilibrio, las empresas obtienen la rentabilidad necesaria para mantener su actividad, pero no más. Es decir, para las empresas, operar en un mercado de competencia perfecta es siempre la peor opción. Así, si una actividad económica resulta atractiva porque permite obtener a los empresarios una rentabilidad superior a la de otras actividades alternativas, otras empresas decidirán también dedicarse a esta actividad especialmente rentable. La entrada de nuevos participantes en el mercado hará que aumente la competencia y, como consecuencia, el margen de beneficio de los empresarios se reducirá hasta que alcance la misma rentabilidad que las otras actividades económicas. Si, por el motivo que fuere, la rentabilidad en el sector se reduce por debajo de este umbral de rentabilidad mínima exigida, las empresas empezarán a cerrar.

Aunque resulta muy complicado encontrar sectores que se acojan perfectamente a esta descripción de mercado de competencia perfecta, sí que podemos encontrar numerosos ejemplos que muestran cómo existen mercados cuyo funcionamiento se aproxima mucho al descrito. Por ejemplo, allá por los lejanos años 80, apareció un artilugio que se denominó reproductor de vídeo. Los reproductores de vídeo se conectaban a la televisión y, si se introducía un videocasete se podía visualizar el contenido del mismo, normalmente una película. Estos artilugios fueron ganando en popularidad y con ellos las tiendas en las que se alquilaban los videocasetes, que se denominaban videoclubs. Al principio había pocos videoclubs, pero pronto empezó a aumentar su número de forma vertiginosa. Obviamente la rentabilidad elevada de los primeros videoclubs llamó la atención de otras personas con espíritu emprendedor que decidieron abrir ellas mismas este tipo de negocio. Mientras la rentabilidad de los videoclubs 
fue siendo elevada, hubo más personas que entraron en el negocio, hasta que se alcanzó un punto de saturación. A partir de este momento el número de videoclubs comenzó a descender. Finalmente, en años más recientes, la aparición de internet y de canales de televisión especializados han hecho que en la actualidad no queden prácticamente videoclubs, que ya no alquilaban cintas de vídeo sino DVDs. Esta historia nos muestra de forma muy sencilla cómo funciona el mercado de competencia perfecta y cómo esta competencia obliga a los oferentes a ajustar precios y reducir su rentabilidad debido a la entrada de nuevos competidores en el sector. Un ejemplo más reciente lo tenemos en las agencias inmobiliarias, que surgieron como champiñones con el alza del sector y desaparecieron bruscamente con la explosión de la burbuja inmobiliaria.

En cualquier caso, debemos recordar que, de entrada, no existe ningún mercado que sea exactamente de competencia perfecta: no hay dos empresas iguales. Dicho lo cual, podemos afirmar no obstante que muchos de los negocios de pequeño comercio y distribución como panaderías, bares, peluquerías, zapaterías y, en general, las típicas tiendas de barrio se ajustan bastante bien al modelo descrito: son pequeños, están sujetos a mucha competencia y tienen una rentabilidad muy ajustada. Aquellos negocios que consiguen ser más rentables lo han conseguido, como veremos, porque han conseguido diferenciarse un poco de sus competidores.

Una situación similar ocurre en el sector industrial, donde la competencia entre las pequeñas y medianas empresas es muy grande.

\subsection{CÓMO EVITAR LA COMPETENCIA Y AUMENTAR LOS BENEFICIOS}

Como hemos comentado, esta situación de competencia perfecta que obliga a las empresas a conformarse con una rentabilidad mínima no es del agrado de los empresarios, quienes deben esforzarse por salir de la prisión que representa para ellos la competencia perfecta. ¿Como lo pueden conseguir? Bueno, eso es precisamente lo que se supone que enseñamos en las Facultades de 
Administración y Dirección de Empresas. Todas las empresas, pequeñas y grandes, pueden implementar estrategias que les permitan diferenciarse de sus competidores, que es de lo que se trata en última instancia. Pasar del gris al multicolor.

En muchos sectores hay empresas que, por unos $u$ otros motivos, han conseguido alcanzar una posición dominante que les permite obtener rentabilidades superiores puesto que han escapado al rígido control de la competencia perfecta. ¿Cómo lo han conseguido? Pues rompiendo los barrotes que configuran la celda de la competencia perfecta. En realidad, son muchas las características que hacen que los mercados se alejen del modelo puro de la competencia perfecta y que pueden ser utilizadas por las empresas en su favor, especialmente en algunos sectores:

- Uno de los casos más fáciles de detectar es el mercado monopolístico, donde ya no existe competencia entre empresas puesto que solo hay una empresa en el mercado que ofrezca ese producto concreto. Los monopolios pueden ser de diversa naturaleza y deberse a diferentes motivos, como la propiedad de una patente, derechos exclusivos de uso, concesiones administrativas, legislación favorable...

- En otros casos, las empresas disfrutan de ventajas competitivas que afloran como consecuencia de procesos tecnológicos exclusivos, menores costes de transporte, fiscalidad ventajosa o aspectos como la gestión de recursos humanos o la clarividencia del equipo directivo.

- Frente a los productos perfectamente idénticos de la competencia perfecta, las empresas buscan la diferenciación mediante las marcas, el etiquetado, la calidad del producto etc.

- Ese afán por la diferenciación imposibilita la comparación de productos. Además, de entrada, muchos productos son poco homogéneos o comparables. Pensemos en el caso de una hipoteca, por ejemplo, donde no solo hay que comparar el tipo de interés y la duración del préstamo, sino diversas comisiones, la necesidad o no de contratar un seguro de vivienda, de vida, tarjetas de crédito etc. O un automóvil, donde junto con las características físicas intervienen también factores más subjetivos. 0 
el caso del vino: ¿Cómo elegir entre dos vinos del mismo rango de precio sin haberlos consumido previamente?

- Muchos mercados son, per se, poco transparentes. Y eso que hoy en día, gracias a internet, disponemos de numerosos buscadores que comparan precios y ofertas de vuelos, hoteles, seguros... donde el producto que se compara es relativamente homogéneo. Aun así, muchos mercados se encuentran muy fragmentados, por lo que son poco transparentes.

- En muchos sectores sí que existen barreras de entrada y salida. Por lo general, para abrir ciertos negocios es necesario invertir grandes sumas de dinero, por ejemplo, si me quiero dedicar a la producción eléctrica a gran escala o a la fabricación de automóviles o de microchips. En otros casos, el acceso a los canales de distribución puede ser una barrera insalvable. En otras ocasiones sólo puedo entrar en un sector si dispongo de la tecnología específica. A veces, barreras culturales pueden impedir la entrada. Por lo general, las empresas que ya operan en un sector intentan levantar todas las barreras de entrada posibles y así evitar la competencia. En muchas ocasiones, las grandes multinacionales y también empresas medianas se sirven de contactos políticos para este fin. Por otro lado, cuando se ha realizado una inversión, especialmente si es grande, las empresas suelen ser reacias a reconocer que se han equivocado al hacerla, si da diera el caso, lo cual es una barrera de salida, pues salir del mercado implica reconocer las pérdidas generadas.

En términos generales, podemos decir que son los activos intangibles de las empresas los que les permiten romper las restricciones de la competencia perfecta, diferenciarse y obtener mayor rentabilidad de sus inversiones. Obviamente, esto es bueno para las empresas y es su obligación desarrollar estos activos intangibles y maximizar su beneficio. Cuanto más dificulten la competencia, mejor para ellas.

Lo que ocurre es que, lo que a nivel microeconómico puede ser beneficioso para una sola empresa, a nivel macroeconómico puede que ya no lo sea tanto. Es decir, que lo bueno para una empresa en particular puede ser malo para la economía en general. Concretamente, depende de cómo se consigue esa 
diferenciación frente a las demás empresas y muy especialmente de cómo afecta a la entrada de nuevos competidores.

\subsection{EL PAPEL DEL ESTADO COMO GARANTE DE LA COMPETENCIA ENTRE EMPRESAS}

Debemos recordar que la premisa es que los mercados de competencia perfecta son los que mejor consiguen realizar la asignación de recursos, son los más eficientes en términos económicos. $Y$ hemos visto que eso se debe a la competencia existente entre las empresas participantes, que hace que las ineficientes desaparezcan del mercado. En este contexto, la labor del Estado es innecesaria, puesto que su intervención no mejorará la asignación de recursos: el Estado no va a poder hacer las cosas mejor que las empresas.

Pero, ¿qué ocurre cuándo la competencia entre empresas desaparece? ¿qué ocurre si no pueden entrar nuevas empresas competidoras? Pues que esa asignación eficiente de los recursos desaparece de pronto. Las empresas, sin tener que estar alerta por la lucha constante entre competidores, dejarán de ser eficientes. Lógicamente, existen multitud de acciones y estrategias de las señaladas en los párrafos anteriores que las empresas pueden implementar para diferenciarse de sus competidores y aumentar sus márgenes de beneficio que no suponen ningún obstáculo a la competencia. No obstante, sí que existen actuaciones o circunstancias que impiden de manera determinante la competencia en un sector.

De este razonamiento se desprende que una de las principales funciones del Estado en la economía es, precisamente, vigilar que los diferentes mercados permitan la sana competencia entre empresas, eliminando las barreras de entrada, luchando activamente contra los monopolios y actividades varias limitadoras de la competencia.

En España, la UE y EEUU existen organismos públicos especializados en estos temas que constantemente se ven obligados a actuar, pues las empresas, las grandes multinacionales especialmente, pero no solo ellas, tienen querencia, obviamente, a limitar la competencia, aunque sea de forma fraudulenta. 
Llegados a este punto es fundamental subrayar un aspecto que se viene repitiendo a lo largo de este ensayo debido a su importancia y a la escasa atención que se le suele prestar: el peligro de la concentración del poder en unas pocas manos. Si bien en términos de poder político sí que aceptamos casi de manera intuitiva la separación de poderes de Montesquieu, cuando se trata de limitar la acumulación de poder económico la situación cambia radicalmente. Lo cual no deja de ser un fenómeno interesante, puesto que el poder económico, las personas que poseen la riqueza material, el dinero, perfectamente pueden corromper y controlar los poderes ejecutivo, legislativo y judicial. Pueden controlar incluso a la opinión pública a través de su influencia sobre los medios de comunicación de masas, de los que son accionistas de referencia y cuyos ingresos dependen en gran medida de la publicidad de estas grandes empresas y del Estado. Tal vez sea precisamente por este control que, de entrada, nos resulte chocante hablar de restringir la concentración y acumulación de poder económico y pensemos que se trata de ideología comunista, cuando en realidad este control es un requisito indispensable para garantizar la supervivencia del sistema capitalista y el libre mercado.

Efectivamente, en el ámbito político, los casos de corrupción y manipulación de poderes están a la orden del día. Esa presión sobre los poderes que son, en teoría, ejercidos democráticamente, es desarrollada por las grandes empresas y las grandes fortunas de manera más o menos evidente. $Y$, como podemos imaginar, el interés de las grandes empresas, centradas en maximizar sus beneficios (o al menos el de sus directivos, que son los que toman las decisiones), casi siempre va dirigido a limitar la competencia en el mercado, a frenar a posibles competidores. Los medios de los que disponen son muy diversos: desde conseguir posiciones de dominio de mercado mediante la privatización de empresas públicas creando monopolios, a la obtención de concesiones administrativas en condiciones ruinosas para el erario público, pasando por la formación de oligopolios con actuación concertada sobre precios o repartos de mercados y la obstaculización de la justicia cuando se trata de castigar estos comportamientos contrarios al mercado, así como influyendo en el régimen sancionador; obtención de subvenciones mutimillonarias y rescates a los que sólo pueden acceder las empresas más grandes; fiscalidad ventajosa 
que les permite acumular beneficios y acrecentar aún más su poder y un largo etcétera.

En base a lo que se acaba de exponer, un factor a considerar es que la intervención del Estado en la economía, aun en los casos en que sea aconsejable, puede realizarse de forma acertada o no. De hecho, en numerosas ocasiones interviene de forma radicalmente opuesta a la que estoy defendiendo en este ensayo, promoviendo la concentración de poder, facilitando monopolios, oligopolios y limitando drásticamente la competencia en favor de ciertas compañías, grandes multinacionales, pero también medianas empresas, con contactos familiares o de amistad con los políticos de turno. En cualquier caso, la actuación del Estado, al menos un Estado que aspira a alcanzar cuotas altas de democracia, como es España, siempre será más fácil de ser controlada por los ciudadanos a través de diversas fórmulas de participación que no la actuación de las grandes empresas, que siempre tenderán a la acumulación de poder, un poder que necesariamente tiene repercusiones negativas en la sociedad al limitar la libre competencia en igualdad de condiciones y que mina en su base al sistema capitalista, transformándolo en un "capitalismo de amiguetes", donde el Estado interviene en la economía canalizando grandes cantidades de dinero público hacia las clases dominantes y legislando a su conveniencia.

Finalmente, aunque no existan intereses ocultos, en no pocas ocasiones la regulación a la que se enfrentan las empresas es farragosa, las trabas burocráticas interminables, los costes administrativos enormes... En resumidas cuentas, al igual que la acción de las empresas en la economía puede ser positiva o negativa, la acción del Estado, aun cuando sea conveniente, también se puede realizar de forma tal que no cumpla su objetivo. Su éxito o fracaso dependerá de cómo se implemente. 



\section{LOS FALLOS DEL MERCADO DE COMPETENCIA PERFECTA}

Hasta el momento he puesto diversos ejemplos de mercados que se pueden aproximar bastante a la competencia perfecta. En estos casos el Estado simplemente debe vigilar que se mantenga esa competencia si es que aprecia que pudiera peligrar.

No obstante, por su propia naturaleza, existen algunos mercados cuyo funcionamiento no se puede aproximar al de los mercados de competencia perfecta, por sus características específicas. En estos casos, y siguiendo el razonamiento anterior, el Estado debe intervenir: las empresas no son capaces por sí mismas de realizar una asignación eficiente de los recursos. Pueden ser capaces de maximizar su beneficio particular, sí, pero en este caso ese beneficio puede estar enfrentado al interés general. En realidad, son bastantes los sectores económicos en los que el Estado debe intervenir si seguimos esta premisa (sanidad, banca, educación, infraestructuras, energía...), empleando diferentes formas de intervención (prestación y producción directa del Estado, regulación, política fiscal...).

Pero es que, además, incluso los mercados de competencia perfecta que hemos descrito adolecen de una serie de problemas que hacen que el Estado deba intervenir: las externalidades, los desequilibrios macroeconómicos y la falta de equidad en la redistribución de la riqueza.

\subsection{LAS EXTERNALIDADES}

En ocasiones puede suceder que en un mercado de competencia perfecta los productores principalmente, pero también los consumidores, no se hagan responsables de los daños que su actividad ocasiona a terceras personas. Este sería el caso de una externalidad negativa. En estos casos el precio de venta no recoge el verdadero coste que ocasiona la actividad (que es absorbido por terceras personas) y el mercado deja de ser eficiente: se produce demasiada 
cantidad de este bien. Efectivamente, si los productores o los consumidores tuvieran que pagar por el daño que generan, el coste a asumir sería mayor y puede que muchos consumidores ya no estuvieran dispuestos a comprar ese producto a mayor precio. Bajaría la demanda y algunas empresas incluso tendrían que desaparecer.

El ejemplo típico de una externalidad negativa es la contaminación. Pensemos en los productos que contienen envoltorios de plástico o en los múltiples productos de plástico de usar y tirar. Los consumidores pagan un precio por el producto, con el que satisface una necesidad, y la empresa manufacturera obtiene un beneficio. Todos contentos. ¿Todos? Realmente no. Resulta que ese plástico debiera ser reciclado, lo que exige unos complejos y costosísimos sistemas de recogida y tratamientos de residuos. Eso en el caso de que se puedan reciclar. En la mayor parte de las ocasiones estos plásticos acaban incinerados, enterrados y, especialmente, en el mar o se envían a países en vías de desarrollo donde les espera el mismo final pero lejos de nuestra vista. Obviamente esto supone un problema enorme para el medioambiente. Por un lado, al quemarse los plásticos, aumenta la contaminación del aire y el efecto invernadero. Por otro, el suelo se contamina, y también el agua. En los mares, los peces y otros animales ingieren los plásticos y microplásticos que les pueden llegar a ocasionar la muerte. Y luego las personas nos comemos los peces y el plástico, lo que presumiblemente no sea lo mejor para nuestra salud. Como conclusión, el hecho de que una persona obtenga una satisfacción comprando un producto de plástico tiene como consecuencia una disminución en la calidad de vida de todas las personas del planeta y en el de las generaciones futuras.

Ejemplos de externalidades negativas hay muchos, también fuera del ámbito estrictamente económico. Cuando alguien fuma en un recinto cerrado, cuando nos saltamos un semáforo en rojo, cuando pintamos las paredes de los edificios y monumentos públicos, cuando ponemos la música del móvil a todo volumen en un parque para compartir el regetón con todo el vecindario... En todos estos casos, nuestras acciones nos aportan un bienestar a costa de generar un coste o un malestar a los demás. En todos estos casos es necesaria la intervención del Estado para evitar la generación de las externalidades. Así, generalmente existen normas que limitan estos comportamientos nocivos y, si las personas no 
son consideradas con sus conciudadanos y además se saltan las normas, generalmente se les multa. Lo óptimo sería que nuestra educación nos permitiera identificar cuándo estamos generando externalidades negativas y reprimir nuestra conducta, pero, por desgracia, esto no es así en muchos casos. Ni con las personas, ni con las empresas.

En el ámbito que nos ocupa más directamente, el papel del Estado en la economía, las externalidades que ocasionan las empresas son las que tienen mayor importancia económica. Y, por otro lado, suele ser más sencillo controlar a las empresas que a los consumidores. Por ejemplo, si se quiere reducir la contaminación del aire ocasionada por los vehículos de combustión, los coches a gasolina y diésel, se puede regular el acceso con esos vehículos a ciertos lugares o los días en que pueden ser utilizados, es decir, se puede regular la actividad de los consumidores, puesto que, en última instancia son los responsables de la contaminación, con independencia de que no les quede otra alternativa que coger el coche, por ejemplo, para ir a trabajar. Pero también se puede regular a los productores. Obviamente, si los coches contaminan menos, tanto mejor. $Y$ es más sencillo influir en el comportamiento de 15 empresas fabricantes de coches que en el de 500 millones de conductores. En general, se trata, por diferentes vías (incentivos, restricciones, sanciones), de incidir en las decisiones de tanto consumidores como empresas para reducir el efecto negativo de las externalidades generadas por el uso de los productos, y obligar a los implicados a internalizar las externalidades negativas, a asumir el coste que, de otro modo, debemos asumir todos los demás.

Por otro lado, es muy común que la externalidad no se produzca en el momento del consumo, sino en el momento de la producción y que el consumidor ni siquiera tenga conocimiento de su existencia. Así, es habitual que la contaminación al medioambiente se genere durante el proceso productivo y que la única responsable sea la empresa productora. Pensemos en la contaminación de las aguas y el suelo por parte de empresas mineras y petroleras, de la contaminación por emisión de CO2 de las centrales térmicas de carbón, la contaminación del aire, los numerosos vertidos incontrolados de la industria textil, el empleo de productos químicos a gran escala en la agricultura con 
consecuencias nefastas sobre la calidad del suelo y la salud de los habitantes de las áreas circundantes y el exterminio de animales tan importantes para nuestra supervivencia como las abejas, la generación de residuos tóxicos, las técnicas de pesca que esquilman los recursos marinos, la extinción por sobreexplotación y eliminación de hábitats de especies animales y vegetales... todas estas actividades ocasionan daños tremendos en el patrimonio común y, a gran escala, ponen en peligro la supervivencia de millones de personas y suponen un enorme riesgo para todos. $Y$, no nos dejemos asustar ni engañar por amenazas apocalípticas: estas actividades perniciosas no son imprescindibles para alcanzar un bienestar suficientemente confortable y ya hay alternativas de producción factibles y económicas. El problema es simplemente que estas alternativas modifican sensiblemente el statu quo, pues implican una reasignación (más eficiente) de los recursos económicos.

Lo más curioso del asunto es que en un mercado de competencia perfecta no se tiene que resarcir a los demás por el daño que se les está ocasionando, por lo que las empresas no tienen ningún incentivo económico para dejar de contaminar, puesto que, en el corto plazo, sus productos serían más costosos de producir y si se subiera su precio para mantener el margen de beneficio se venderían en menor cantidad, por lo que acabaría igualmente afectando a los beneficios empresariales.

Por lo tanto, en un mercado de competencia perfecta sin intervención estatal, en un mercado puramente capitalista y liberal donde solo actúan las fuerzas del mercado, la lucha contra la contaminación y contra el cambio climático o contra la expansión del agujero de la capa de ozono son batallas perdidas. Por cierto, que el caso del agujero de la capa de ozono es un buen ejemplo de acción coordinada y exitosa de los Estados regulando los mercados. Se podría argumentar que los consumidores deberían ser responsables y pensar en el bien común y dejar de comprar esos productos. Pero, ¿y si no hay productos alternativos? ¿y si los consumidores no son conscientes de la verdadera gravedad del problema? ¿y si hay, que los habrá, consumidores egoístas a los que no les preocupa el deterioro del medioambiente, ya que, al fin y al cabo, ellos habrán muerto antes de que el problema estalle? Recordemos que hoy en día aún hay gente que no cree, o dice no creer, en que la actividad económica 
humana esté generando un cambio climático. También hay que recordar el enorme poder que tienen los medios de comunicación de masas para manipular la opinión pública, y que estas empresas obtienen gran parte de estos ingresos de la publicidad, por lo que los lobbies pueden influir en la información que reciben los ciudadanos y ralentizar o frenar absolutamente cambios en la mentalidad y el comportamiento de los consumidores. A esto se podría replicar que los consumidores también se pueden agrupar y poner publicidad, pero, seamos realistas, esto es mucho más complejo, y lleva un proceso más lento. Básicamente, resulta mucho más difícil aglutinar en un solo grupo a millones de personas que pueden obtener un beneficio personal no monetario incierto a largo plazo (frente a un coste monetario real actual) que coordinar a unas pocas empresas para conseguir o mantener un beneficio monetario actual y conocido y para las que el éxito de su acción puede suponer el poder continuar o no con su actividad económica. Es por ello que los lobbies empresariales son tradicionalmente más efectivos que otros lobbies como asociaciones de consumidores u ONGs protectoras del medio ambiente o los derechos humanos. Por otro lado, las empresas también podrían, motu proprio, en aras de la manida responsabilidad social corporativa (¡qué bonito tema!), iniciar una campaña contra la contaminación. Pensemos que la contaminación también les afecta a ellas (a sus trabajadores, a sus directivos y a sus accionistas). Pero ya vemos que esto no ocurre, pensemos, por ejemplo, en el caso del plástico. Se trata, por otro lado, de una decisión lógica: ¿por qué tengo que empezar yo a contaminar menos? Contaminar menos implica generalmente asumir ciertos costes a corto plazo que me restan beneficios si no consigo recuperarlo mediante mayores ventas o mayores precios, transformando esa inversión en una ventaja competitiva, lo cual no suele ser sencillo y siempre es arriesgado.

En cualquier caso, si debemos esperar a que las fuerzas del mercado actúen y frenen, por ejemplo, la producción y vertido de plásticos, creo que estamos todos de acuerdo en que estamos perdidos. Especialmente porque los cambios en el mercado, aunque es muy probable que efectivamente surjan en el largo plazo como consecuencia de la lenta concienciación de parte de la población conforme se vayan agravando los problemas y del aumento de la competencia entre empresas, pueden llegar muy tarde. Incluso con la intervención del Estado llegan tarde puesto que, como hemos comentado, la relación del Estado con las 
grandes empresas y sus grupos de presión es muy estrecha y generalmente los políticos no se atreven o no pueden enfrentarse directamente a ciertas industrias contaminantes. Pero, en fin, más vale tarde que nunca. Al menos de momento.

Pero no todo son externalidades negativas, también hay externalidades positivas. El problema es que en los mercados de competencia perfecta, esos que de alguna manera fomentan las externalidades negativas porque permiten reducir costes a las empresas, las externalidades positivas son una rara avis, no hay incentivos para generarlas.

Una externalidad positiva aparece cuando la acción de una empresa, un individuo, una Administración, repercute positivamente en su entorno, habiendo por lo tanto otras personas que se benefician de esta acción sin tener que soportar sus costes. El ejemplo típico es el de una persona que pinta la fachada de su casa: ella sale beneficiada, pero también los vecinos, puesto que es más agradable vivir en una calle con las fachadas pintadas que en una descolorida. Todos se benefician, pero el que ha asumido el coste es el propietario de la vivienda. En un mercado de competencia perfecta se producen menos bienes generadores de externalidades positivas de las que se producirían en una situación en la que el productor se viera compensado por todo el bienestar que efectivamente genera.

Pensemos, por ejemplo, en temas como la educación, la sanidad, la investigación básica, la protección del medio ambiente o la construcción de infraestructuras. Como sabemos, las empresas privadas se pueden encargar perfectamente de muchos de estos temas. El problema es que no lo harían de forma eficiente, puesto que gran parte de los beneficios generados a la comunidad no pueden transformarse en beneficio económico para la empresa. Empecemos con la educación y la cultura. La educación y la cultura generan numerosas externalidades positivas para la sociedad. Es evidente que no es lo mismo vivir en una sociedad donde la población dispone de muchos conocimientos que en una sociedad analfabeta e ignorante. La economía, las empresas, requieren de mano de obra cualificada. Pero es que la propia supervivencia de las sociedades democráticas depende de la formación ciudadana de sus integrantes, del conocimiento y aprecio a sus derechos y 
libertades alcanzados tras numerosos enfrentamientos sociales y que deben seguir defendiendo frente a las constantes amenazas. En un mercado de competencia perfecta, no todas las personas pueden acceder a la educación y la cultura. De hecho, esta es la situación en numerosos países donde el Estado no interviene directamente. Por otro lado, los contenidos de esa educación también pueden estar sesgados si se deja a las empresas privadas o a la iniciativa privada en general que elijan qué enseñan a sus alumnos, ya que son más fácilmente manipulables que los Estados. Por no hablar del caso español, pensemos que en EEUU se intenta reiteradamente introducir el creacionismo en las escuelas. En un país donde aún hay gente que cree que la tierra es plana y el ser humano no ha llegado aún a la luna, no es de extrañar.

La salud general de la población, lo que se denomina salud pública, es otra fuente de externalidades positivas. De nuevo nos encontramos en un ámbito en el que también actúa el sector privado, y de nuevo de forma insuficiente. Recuérdese que no se está criticando la actuación del sector privado, simplemente se está justificando que la actuación de éste, siempre dentro de la lógica del mercado, es insuficiente y por eso debe actuar también el Estado. Veamos. Como es de esperar, las empresas privadas se ocupan de la salud de las personas a cambio de un pago. Como hay personas que no pueden pagar, pues se quedan fuera y no acceden a los servicios de salud. Con independencia de los dilemas morales y el impacto sobre el bienestar de las personas, esta carencia de cuidados médicos tiene implicaciones muy negativas. Sobre estas personas, obviamente, pero también sobre los que se pueden permitir un médico, una operación y medicinas. De ahí que hablemos de las externalidades positivas de la salud pública y de la necesidad de que el Estado la promueva. Esto es fácil de entender. En general, vivir en un entorno con gente enferma aumenta el riesgo a enfermar, lo cual ya es negativo de por sí. Pensemos, además, en otras circunstancias. Si la mitad de la población no se vacuna contra una enfermedad (por el motivo que sea) y luego viene una epidemia, los costes sociales y económicos pueden ser enormes, también para las empresas privadas, que se quedan sin mano de obra y sin consumidores. Otro ejemplo: $\mathrm{Si}$ las personas pobres no pueden pagar un tratamiento completo con antibióticos y solo lo siguen durante unos días, es más probable que las bacterias generen 
cepas resistentes a los antibióticos, lo que también repercutirá en los enfermos que pueden costearse los antibióticos.

La investigación básica es aquella de la que no se espera obtener resultados comercializables a corto plazo. Otra característica es que suele ser bastante costosa y no siempre se alcanzan los resultados deseados, es decir, es muy arriesgada. Sin embargo, este tipo de investigación es fundamental para el avance de nuestro conocimiento y la tecnología. Muchos de los avances científicos se basan en investigación básica previa. ¿Quién suele llevar a cabo este tipo de investigación? Efectivamente, los Estados directamente o empresas privadas con financiación estatal. Es decir, el Estado tiene que intervenir. Si hubiera que esperar a que las empresas se involucraran en la investigación básica, el avance del saber sería mucho más lento. Una vez más, se trata de un hecho lógico y predecible: las empresas no se pueden embarcar en unos costes de los que no esperan obtener ningún beneficio. Un recordatorio: recuérdese que estamos tratando siempre casos en los que el Estado debe intervenir en la economía, aun cuando haya competencia perfecta. Estamos hablando siempre de un entorno de competencia perfecta que es, como hemos visto, el que asigna los recursos productivos más eficientemente. Así que no vale argumentar que las grandes empresas como Google (Alphabet, en realidad), sí que invierten mucho en investigación básica. En ese caso no estamos ante mercados de competencia perfecta, por lo que el Estado tiene otros motivos para intervenir en ellos. Por otro lado, nos estamos centrando en la investigación básica, no toda la I+D. Como ejemplo de investigación básica, pensemos en la relacionada con enfermedades raras, la física cuántica o la exploración espacial. A partir de los descubrimientos de esta investigación fundamental, las empresas pueden continuar y desarrollar nuevos productos.

Otro ejemplo de actuación que genera externalidades positivas es la protección del medio ambiente. Hay que tener en cuenta que muchos bienes relacionados con la naturaleza son lo que denominamos bienes públicos, que trataremos más adelante, lo que hace que estos bienes no se puedan intercambiar en mercados de competencia perfecta, por lo que su producción es insuficiente, lo que implica que la intervención del Estado es necesaria. En cualquier caso, la existencia de 
externalidades positivas ya justica su intervención. A estas alturas, creo que no hace falta entrar a debatir sobre la importancia que el entorno natural tiene en nuestras vidas. $Y$ también para la economía. Pensemos en todos los turistas que recibimos en España, que vienen a tomar el sol en la playa. Si las playas están contaminadas o el clima cambia tendremos problemas. Las actuaciones encaminadas a preservar la calidad del medio ambiente generan externalidades positivas, pues nos afectan a todos. Pero imaginemos que las empresas del sector turístico se tuvieran que poner de acuerdo para evitar la contaminación del agua en las playas, la limpieza de la arena y recogida de plásticos y residuos... por no hablar de la lucha contra el cambio climático. Resulta obvio que no sólo no tienen incentivos a nivel particular para hacerlo (ya lo harán las demás empresas y yo me beneficiaré) sino que se trata de una tarea ingente con un coste que no pueden asumir. Además, también habría otras muchas empresas que se beneficiarían, así como los ciudadanos particulares. Moraleja: De estas actuaciones se debe encargar el Estado, que para eso se recaudan los impuestos. Ciertamente. Se trata de actuaciones necesarias que mejoran la calidad de vida de toda la población y la actividad económica, pero que no se llevarán a cabo con la suficiente intensidad si las tiene que acometer la iniciativa privada.

Vemos cómo existen actuaciones de gran envergadura que producen externalidades positivas y que no pueden ser abordados por la iniciativa privada y que, necesariamente, necesitan de la coordinación del Estado. Porque, además, se requiere del poder de coacción del Estado para llevarlos a cabo de forma eficiente. Un ejemplo de ello es la planificación territorial y la construcción de infraestructuras. En primer lugar, se requiere una visión global del territorio y seguir criterios no solo de eficiencia, sino también de equidad, buscando el interés público general. Por otro lado, se necesita la capacidad coercitiva del Estado para llevar a cabo ciertas actuaciones, como expropiar los terrenos por los que debe pasar una carretera. Si, por ejemplo, fuese una empresa privada la encargada de trazar el recorrido del ferrocarril, nos encontraríamos con situaciones como las que se ven en las películas el oeste americano, en las que la empresa constructora amenaza a los indefensos campesinos para que les 
vendan los terrenos por los que debe pasar la vía, hasta que llega un pistolero y soluciona el problema.

De esta forma, el Estado influye en la propiedad privada por un interés general superior y ordena el territorio, diseñando las vías de comunicación y suministros, delimitando zonas naturales protegidas, protegiendo las costas, ubicando polígonos industriales o aprobando la ordenación de las ciudades.

Como conclusión, podemos decir que cuando hay externalidades (positivas o negativas) el equilibrio de mercado no es eficiente. Así, hay una producción excesiva de aquellos bienes que generan externalidades negativas (como la contaminación), mientras que se producen menos bienes de los que generan externalidades positivas (como la limpieza de espacios comunes). Por esta razón, el Estado debe actuar aun con mercados de competencia perfecta, pues también ellos pueden ser ineficientes en la asignación de recursos. Esta actuación se materializa normalmente mediante la regulación, castigando a los infractores, y el apoyo económico a ciertas actividades mediante subvenciones, financiación o beneficios fiscales. Y también mediante la actuación del Estado, bien directamente o a través de empresas privadas sufragadas por el Estado. Finalmente, subrayar que, si estos problemas se dan en un contexto de competencia perfecta, igualmente se pueden dar en el caso de monopolios y oligopolios.

\subsection{ESTABILIZACIÓN ECONÓMICA}

Incluso si todos los mercados pudieran funcionar en un entorno de competencia perfecta, el Estado debe intervenir en la economía para crear y mantener la estabilidad económica, es decir, unas condiciones macroeconómicas que favorezcan el crecimiento sostenible de la economía.

Hay que tener en cuenta que los diferentes agentes económicos, productores y consumidores, en un mercado de competencia perfecta, se mueven por sus 
incentivos particulares, para maximizar su, digamos, bienestar. Pero la suma de estas actuaciones individuales no tiene que ser necesariamente lo mejor para la economía del país en su conjunto. Dicho de otra manera, lo que para una empresa en particular puede ser positivo, a nivel agregado puede tener consecuencias negativas. Además, hay factores que escapan al control de las empresas y que solo pueden ser dirigidos por el Estado.

Dentro de la política de estabilización se encuentra el control de algunas de las principales variables macroeconómicas: el tipo de interés, la inflación y el tipo de cambio. Obviamente, ninguna empresa a nivel individual puede realizar ninguna acción para influir en estas variables. Sin embargo, estas variables influyen en la actividad económica de todas las empresas y los consumidores, de manera más o menos directa, a corto o medio plazo. Por otro lado, es importante subrayar que, en la actualidad, incluso los Estados pueden tener grandes problemas para controlar estas variables de forma autónoma siendo necesaria la cooperación y coordinación con otros países en cuanto a las políticas económicas a implementar. Esta situación se debe al alto grado de globalización, que hace que las economías sean muy interdependientes. $Y$ se pone especialmente de manifiesto en el caso de economías pequeñas. En el caso de España, en el seno de la UE, el grado de coordinación es tal que directamente no existe una política nacional, pues se ha cedido la soberanía sobre estos temas (tipos de interés, inflación y tipo de cambio) al Banco Central Europeo.

Otro factor importante dentro de la estabilidad económica son el déficit público y la deuda pública. Lógicamente, compete al Estado decidir sobre tales magnitudes, si bien también en este caso los organismos internacionales tienen gran influencia.

Operar en un entorno de estabilidad es fundamental para las empresas. Y esa estabilidad debe ser tanto política, como social y económica. En numerosas ocasiones estas tres vertientes están relacionadas, aunque no siempre, pues hay empresas que pueden sacar rédito de, por ejemplo, la inestabilidad social. La importancia de la estabilidad se hace especialmente patente cuando pensamos en países o en periodos en los que no existe y observamos cómo la inestabilidad afecta a la economía y a la calidad de vida. 
Pensemos por ejemplo en la inflación desbocada. La hiperinflación, una subida generalizada muy pronunciada y rápida de los precios, tiene un efecto devastador en las clases medias, que ven cómo el dinero que han ahorrado a lo largo de su vida se esfuma. Las clases más pudientes, las personas verdaderamente ricas, también se ven afectadas, pero en menor medida, pues tienen gran parte de su riqueza invertida en bienes inmuebles y por lo general tienen más medios para invertir en el extranjero. Los pobres, al no tener ahorros, no los pierden. Pero la hiperinflación también afecta al consumo y a la inversión. El tráfico comercial puede congelarse. El dinero puede perder absolutamente su valor. Y, en fin, la economía en general se paraliza, con todas las consecuencias. En esta situación, el mercado de competencia perfecta está muerto. El único que puede actuar para evitar estas situaciones y, en su caso, reactivar la economía, es el Estado.

La inflación se debe, entre otros factores y con algunas matizaciones, a la cantidad de dinero que hay en una economía y a la velocidad a la que circula. La cantidad de dinero depende en gran medida de los préstamos que concedan los bancos: a más préstamos, más dinero y, a medio plazo, más inflación. Pero hay que tener en cuenta que el negocio de los bancos es precisamente otorgar préstamos, por lo que, sin regulación, tienen incentivos para ser una fuente de inestabilidad económica, que será mayor cuanto más grande sea el sector. Para controlar la actividad bancaria, el Estado controla los tipos de interés a través de la política monetaria. Si los tipos de interés son altos, las empresas y los consumidores piden menos préstamos a los bancos. Y si son bajos, están más dispuestas a endeudarse. Es decir, las decisiones de inversión y consumo se ven afectadas por los tipos de interés. Éstos también influyen en el mercado laboral. Empresas y consumidores se encuentran con un entorno económico en el que no pueden influir. Así, la política de tipos de interés, la denominada política monetaria, si permite que los tipos de interés sean altos, controla la inflación pero frena el crecimiento económico. Por otro lado, en periodos de recesión, se suelen bajar los tipos de interés, y así estimular la inversión, el consumo y la creación de empleo, a riesgo de generar algo de inflación. La decisión sobre qué es más importante, si controlar la inflación o fomentar el empleo, es una decisión política. Así, la Reserva Federal americana tiene también como objetivo fomentar el 
crecimiento económico, mientras que el único objetivo del Banco Central Europeo es el control de la inflación.

Por lo general, el Estado debe intervenir a lo largo del ciclo económico para evitar que las ondas del ciclo sean demasiado pronunciadas. Una opción es la política monetaria. La otra opción es la política fiscal, que hace referencia al gasto público en la economía y a la creación de déficit público, cuando el Estado gasta más de lo que tiene y se tiene que endeudar. Este gasto extraordinario del Estado se justifica cuando la economía entra en recesión y es necesario estimular el consumo por diferentes vías, como la inversión directa del Estado. En una recesión económica, las empresas observan cómo el entorno económico se modifica de forma que su supervivencia se complica sin que las propias empresas sean culpables de dicha situación. Recordemos la situación generada con motivo de la crisis de 1929, cuando la economía norteamericana entró en un círculo vicioso de destrucción económica que solo pudo parar el Estado interviniendo en la economía, en un momento histórico en el que el papel del Estado en la economía había sido muchísimo más reducido que en la actualidad. En principio, se supone que lo más conveniente es que el Estado mostrara equilibrio presupuestario a lo largo del ciclo: que ahorrara en periodos de vacas gordas y se endeudara al llegar la vacas flacas. Por lo general, esta situación ideal no se da, debido, entre otros factores, a los incentivos de los políticos, que son contrarios a este comportamiento racional.

La deuda pública, la inflación y los tipos de interés de una economía también influyen en la relación de dicha economía con el exterior y, muy especialmente, en el tipo de cambio en el mercado de divisas. Este tipo de cambio hace que los productos y servicios nacionales sean más o menos competitivos en los mercados internacionales, que se pueda exportar más o menos. O que se importe menos o más. Es decir, no se trata solo de exportar, sino también de la competencia de las empresas extranjeras en el mercado nacional. Por lo tanto, una empresa nacional se puede encontrar con que, de la noche a la mañana, sus productos ya no son competitivos, sin que esa pérdida de competitividad se le pueda achacar a la empresa. Simplemente, la moneda local se ha apreciado, lo que hace que sus productos sean más caros para los clientes extranjeros y 
los productos extranjeros sean más baratos para los consumidores locales. Sensu contrario, si la divisa nacional se deprecia, los productos locales serán de pronto más competitivos. Pensemos por ejemplo en el turismo. Cuando el tipo de cambio EUR/USD era de 1,50, el turismo español en Estados Unidos aumentó significativamente, así como los vuelos directos a Nueva York, a donde muchos españoles iban a comprar gangas. Sin que los hoteles ni las tiendas neoyorquinas tuvieran nada que ver con este comportamiento.

Gestionar el tipo de cambio es algo absolutamente imposible para las empresas, quienes, por otro lado, tendrán intereses particulares contrapuestos en numerosas ocasiones dependiendo del sector. Existen, además, otros instrumentos para gestionar las diferentes actividades económicas de un país con el exterior y que afectan a la balanza de pagos, tales como aranceles, contingentes, restricciones al movimiento de capitales y un largo etcétera. En el caso de los países europeos, no obstante, se ha producido una cesión de soberanía a favor de la Unión Europea, que a su vez se ha obligado con terceros países mediante tratados internacionales, por lo que los Gobiernos nacionales no pueden ya decidir sobre estas materias.

Para concluir, podemos decir que las empresas, también dentro del contexto de competencia perfecta que estamos analizando, se ven afectadas por un entorno económico generado por la interacción de todas las empresas, pero en el que no pueden influir a título particular. Este entorno y estas interacciones generan desequilibrios macroeconómicos que afectan a la rentabilidad de las empresas, a su crecimiento y desaparición. Para fomentar una economía eficiente, el Estado debe crear organismos que monitoricen la evolución de la economía, recopilando y analizando los datos micro y macroeconómicos, e intervenir en el contexto económico para mantener su estabilidad mediante instrumentos de política monetaria, política fiscal y política económica exterior. 


\subsection{LA REDISTRIBUCIÓN}

Otro gran problema de los mercados de competencia perfecta es la redistribución de la riqueza, concretamente, la concentración de dicha riqueza. Pero no pensemos que con los mercados de competencia imperfecta sí que se redistribuye la riqueza, no, la situación aún es peor.

Uno de los errores de base más comunes en los que caemos todos al analizar la economía es olvidarnos de los niños. Vemos a personas adultas y juzgamos su situación, alegando que su bienestar es fruto de su trabajo y esfuerzo, de sus aciertos y errores $y$, en definitiva, creemos que ellos son los únicos responsables de su situación. Nos olvidamos de que en su momento fueron niños y que no todos los niños gozan de las mismas posibilidades. No todos empezamos la carrera en la misma posición. Por eso es bastante predecible, simplemente mirando el entorno familiar, a qué tipo de trabajo podrá acceder un niño en el futuro o a qué nivel de renta. Si realizará estudios superiores o no. Si completará su formación en el extranjero y aprenderá idiomas. Como ya hemos comentado, el lugar de nacimiento y el seno de la familia en la que se nace influyen decididamente en nuestro futuro, ofreciéndonos y quitándonos oportunidades y protección. Y luego ya está el esfuerzo personal. Pero, ojo, que la educación que hayamos recibido también influye en nuestra capacidad de esfuerzo y nuestras motivaciones, en nuestros anhelos y nuestra determinación.

Pensamos que una economía capitalista nos ofrece a todos posibilidades para mejorar nuestro nivel de vida, siempre y cuando nos esforcemos. $Y$ si fracasamos y caemos en la pobreza es por nuestra culpa. Esta forma de pensar, ligada originariamente a los protestantes calvinistas, es fomentada sin reparos por aquellas personas pudientes que han alcanzado cierto bienestar económico. $Y$ también por los que nos encontramos en situaciones bastante menos ventajosas, pero vivimos sin privaciones. Nos olvidamos de nuestros orígenes y magnificamos el esfuerzo que hemos realizado. Obviamente, hay un pequeño porcentaje de la población que ve mejorar enormemente su estatus social gracias a su esfuerzo y constancia (otros gracias a sus felonías en la política, por cierto), su capacidad intelectual o física (algunos deportistas de élite), o al talento, y algo de suerte, de poder desarrollar actividades especialmente lucrativas (cantantes, actores, profesionales de televisión...). Y otros que caen 
en el escalafón, obviamente, y que también resulta significativo analizar. Por ejemplo, una reducción de la llamada "clase media" resulta especialmente peligrosa para la sociedad.

Pues bien, los mercados de competencia perfecta, aun cuando son eficientes en la asignación de recursos, incluso en ausencia de externalidades pueden generar distribuciones de la renta muy desiguales, grandes acumulaciones de riqueza frente a pobreza absoluta. Esto tiene como consecuencia, en primer lugar, la propia desaparición de los mercados de competencia perfecta debido a la acumulación de poder económico y político en ciertas personas y empresas. Por otro lado, tiene efectos negativos en el consumo, pues las pautas de consumo cambiarán en la población: unos no tendrán suficiente para los productos básicos y otros podrán derrochar en bienes de lujo, lo cual no es de por sí malo. Si el porcentaje de ciudadanos pobres aumenta, el consumo interno caerá y las empresas, o venden sus excedentes en el extranjero (en cuyo caso les trae sin cuidado lo que les ocurra a los nacionales), o también quebrarán, entrando la economía en un círculo vicioso del que solo la puede rescatar la intervención estatal. Resumiendo: la desigualdad más o menos extrema del reparto de la riqueza, o, de otro modo, la acumulación de gran parte de la renta de un país por un grupo reducido de personas tiene efectos negativos para la economía, no solo es una situación reprobable desde el punto de vista ético. Se trata tanto de un problema de equidad como de eficiencia. $Y$ basta echar un vistazo a la historia para ver que esto es así.

Pero, ¿cómo produce un mercado de competencia perfecta que los pobres sean cada vez más pobres y los ricos más ricos? Bueno, imaginemos, que es mucho imaginar, que el mercado laboral fuera un mercado perfecto. Aun en ese caso, se daría la circunstancia, lógica por otra parte, de que las personas de origen humilde serían las que reciben menos educación (ya hemos visto lo que ocurre con la educación con competencia perfecta) y, por lo tanto, solo pueden acceder a los trabajos peor remunerados. Por otro lado, las personas de origen más pudiente acceden a una educación mejor y a los mejores trabajos. Así, los que parten de una posición de salida mejor van acumulando más capital, mientras que los pobres tienen menos capacidad de ahorro. A la hora de crear una empresa o un negocio, el acceso a información, contactos y capital también será desigual. Como se suele decir, el dinero llama al dinero. Así, mientras unos 
tienen más fácil prosperar y emprender, los otros permanecen estancados en sus trabajos mal pagados y tienen más probabilidades de quedar desempleados. En caso de enfermedad, el impacto también será desigual, pues los pobres deberán destinar un porcentaje mayor de su renta a los servicios sanitarios. De esta manera, las diferencias de partida se van agrandando con el tiempo entre las clases sociales si el Estado no actúa mediante políticas de redistribución.

Vemos pues, cómo, incluso con mercados eficientes, existen motivos para que el Estado intervenga. La cuestión radica en cómo debe actuar el Estado.

Por otro lado, tal y como veremos a continuación, existen mercados que necesariamente se alejan de la competencia perfecta, lo que implica que el Estado debe actuar para mejorar su eficiencia. 



\section{LOS MERCADOS IMPERFECTOS}

Como acabamos de ver, existen casos en los que el Estado debe intervenir aun en los mercados de competencia perfecta, que son, por definición, los mercados más eficientes. Con mayor motivo deberá intervenir, lógicamente, en aquellos mercados imperfectos que se alejan de las características de los mercados de competencia perfecta (productos idénticos, información perfecta, empresas precio-aceptantes, sin barreras de entrada o salida etc.). Ya hemos comentado anteriormente que es prácticamente imposible encontrar mercados que se ajusten exactamente a estos condicionantes, si bien los hay que los cumplen de forma razonable. No obstante, existen una serie de actividades económicas de gran importancia cuyas características de partida hacen que no puedan funcionar jamás como mercados de competencia perfecta y otros mercados que requieren la participación del Estado por diversos motivos. A continuación, vamos a tratar las causas que motivan esta situación, que son la existencia de monopolios, bienes públicos, bienes preferentes, fallos en la información y mercados incompletos.

\subsection{LOS MONOPOLIOS}

En algunas ocasiones nos podemos encontrar con que hay una sola empresa que produce un bien específico. Sólo existe esa empresa en el mercado, por lo que los consumidores deben acudir a ella necesariamente si quieren adquirir ese bien. La empresa no tiene rival ni competencia, por lo que ya no es precio aceptante, es decir, puede fijar el precio que más le convenga para maximizar su beneficio. En esta coyuntura, el precio que fijará la empresa será más elevado que el que habría en un mercado de competencia perfecta. Al ser el precio más alto, serán menos los consumidores que decidan adquirir ese bien, por lo que la producción del mismo será inferior a la que habría en competencia perfecta. Si la demanda es inelástica, es decir, si el bien en cuestión es considerado necesario por los consumidores y están dispuestos a pagar más por él, la 
empresa monopolística podrá subir más el precio, aumentando los beneficios más aún.

El monopolio es la situación soñada por las empresas, pues les da la mayor libertad posible para explotar el mercado, libres de competencia. Son diversas las vías para alcanzar esa situación y suelen estar relacionadas con barreras de entrada en un sector concreto o una actividad empresarial específica, que las empresas se cuidarán mucho de proteger. Por ejemplo, antiguamente los costes de transporte impedían la competencia entre regiones más o menos lejanas, creándose monopolios locales. El acceso exclusivo a materias primas también puede dar lugar a un monopolio. Por otro lado, las empresas pueden alcanzar una situación monopolista gracias a su inversión en investigación y desarrollo, mediante patentes que protejan sus productos, o gracias a conocimientos exclusivos que les permitan producir a menor coste y eliminar a sus competidores. Así, parece razonable otorgar una patente a las empresas que descubren un nuevo fármaco, por ejemplo, de forma que puedan producir dicho fármaco con exclusividad durante cierto periodo de tiempo. De lo contrario, si otras empresas pudieran copiar el fármaco, producirlo y comercializarlo, los incentivos para investigar se reducirían drásticamente. En este caso es el propio Estado el que, por medio de la patente, genera una barrera de entrada y otorga un monopolio temporal a la empresa para proteger la innovación.

Se trata, por tanto, de medios perfectamente legítimos que, partiendo incluso de un mercado de competencia perfecta, consiguen que una empresa alcance una posición dominante en el mercado que puede llegar a eliminar a las empresas competidoras. Una vez alcanzada esta posición, los monopolistas tratarán de mantener esta situación mediante barreras de entrada a competidores potenciales. De esta manera, las empresas que quieren entrar a competir por el mercado se encontrarán en situación de inferioridad en cuanto a estructura de costes, pues el monopolista puede tener menores costes gracias a las economías de escala, a la cadena de distribución y a posibles contratos a largo plazo con los clientes más importantes. Además, el monopolista puede amenazar a las empresas competidoras potenciales con una guerra de precios que haría que las nuevas inversiones requeridas para entrar en el mercado no fueran rentables. 
Cuanto mayor sean las barreras de entrada, más podrá abusar el monopolista de su situación dominante. Lo mismo sucede en ocasiones en el caso de los oligopolios, en los que son pocas las empresas que operan en un mercado, cuando éstas suscriben acuerdos para restringir la competencia entre ellas. Por otro lado, no sentirán la necesidad de innovar, pues la competencia es el principal acicate para la innovación. Así, la ausencia de competencia potencial conlleva alejarse de la eficiencia que se alcanza en un contexto de competencia perfecta, siendo los consumidores los principales afectados, al no haber innovación en los productos y ser éstos más caros.

Esta situación motiva la actuación del Estado en aras de evitar los monopolios y fomentar la sana competencia entre empresas. No obstante, existen situaciones en las que lo más eficiente es que haya una sola empresa encargada de producir un producto o, principalmente, prestar un servicio. Es el caso de los denominados monopolios naturales.

En ciertas ocasiones, es difícil que se dé la competencia entre empresas y, en cualquier caso, lo más eficiente es que sea una sola la que se encargue de la producción o prestación de un servicio concreto. En estos casos puede ser aconsejable que sea el propio Estado quien asuma la producción o la prestación del servicio. En las últimas décadas, la solución escogida pasa por que sean empresas privadas las que presten el servicio como monopolistas, pero bajo la regulación del Estado.

Los monopolios naturales se dan básicamente cuando existen grandes barreras de entrada, especialmente ligadas a que no tiene sentido duplicar una red o un servicio. $Y$ precisamente es la construcción de dicha red o infraestructura lo que supone el mayor coste, lo cual representa una barrera de entrada para potenciales competidores, pero también una barrera de salida, pues las empresas que hayan realizado una inversión tan fuerte serán reticentes a darlas por perdidas.

Imaginemos que solo las empresas privadas se dedicaran a la construcción de la red de ferrocarril o de carreteras. Una vez construida una autopista entre dos ciudades, ¿qué empresa construiría otra paralela para hacer la competencia? Por no hablar de que se trataría de una solución ineficiente en términos económicos que además produciría muchas externalidades negativas. Lo mismo 
sucede con la construcción y gestión de puertos. No es eficiente construir un número indefinido de puertos en la costa.

Algo similar ocurre con el desarrollo de las redes necesarias para la distribución de electricidad, agua, gas o las telecomunicaciones. Lo más eficiente en términos económicos es que exista una sola red y, por lo general, solo existe una red. Sólo en algunos casos, como en las telecomunicaciones y precisamente para evitar las situaciones que generan estos monopolios, en España algunas empresas invierten en sus propias redes, dada la falta de inversión de la empresa monopolista para cambiar los antiguos cables de cobre por los de fibra de vidrio. Esta situación demuestra que en algunas ocasiones sí que es posible la competencia en estos ámbitos, por lo que la función del Estado sería fomentar dicha competencia.

El hecho de que las redes pertenezcan a empresas privadas no es un tema baladí. Actualmente, este problema se ha puesto de manifiesto en EEUU, pero nos afecta también directamente a los europeos y al resto del mundo. Se trata de internet y la desaparición de la llamada "neutralidad de la red". Así, ahora las empresas propietarias de las redes de telecomunicaciones en EEUU pueden decidir a qué mensajes dan prioridad y qué mensajes son penalizados. Es decir, pueden decidir en base a criterios propios (como el pago de dinero o quién sea el creador del contenido) qué páginas web o aplicaciones funcionan más rápido y cuáles más lentas. Ni qué decir tiene, esta situación otorga un poder enorme a las empresas privadas sobre cómo fluye la información. Así, grandes ventajas de internet como la mayor transparencia, la libertad de expresión, la multitud de fuentes y diversidad de opiniones podrían peligrar.

Otro ejemplo de competencia en un antiguo monopolio natural lo encontramos en el servicio de correos, que tradicionalmente se prestaba por una única empresa estatal, donde la entrada de empresas competidoras trajo diversos beneficios a los consumidores. No obstante, en muchas ocasiones se debe buscar el equilibrio entre el beneficio empresarial y el interés general. Así, siguiendo con el ejemplo de las empresas de correos, y para el caso español, el Estado determina que el servicio de correos es de interés general, por lo que la red de correos debe llegar a todos los lugares de España. De no fijarse esta condición, podría darse la circunstancia, especialmente en el pasado cuando la 
red de carreteras era infinitamente peor y por lo tanto los costes de transporte eran mayores, que las empresas privadas solo prestaran el servicio entre las grandes poblaciones, con gran volumen de negocio, y se olvidaran de las poblaciones más pequeñas o aisladas o solo lo prestaran a cambio de un precio muy elevado, con los inconvenientes derivados para los habitantes de dichas localidades.

Hasta la entrada de España en la Comunidad Económica Europea (CEE), la posterior Unión Europea, los monopolios naturales eran gestionados directamente por el Estado a través de diversas empresas de titularidad 100\% pública. Junto con estas empresas, el Estado también poseía otras empresas en sectores que se consideraban de importancia estratégica para la nación. A partir de 1986, y muy especialmente durante la segunda mitad de los años 90, las empresas públicas que generaban beneficios se fueron privatizando paulatinamente, tendencia que sigue hasta la actualidad. Muchas de estas grandes empresas, que ahora forman parte del IBEX-35 y están en manos de inversores extranjeros, constituían monopolios y otras gestionaban monopolios naturales, como Telefónica o Red Eléctrica Española.

Al privatizarse, se pasó de un modelo de gestión directa del Estado a uno de regulación, mediante el cual el Estado supuestamente controla a las empresas privatizadas para que no abusen de su posición monopolista. La idea subyacente al proceso privatizador es que la gestión privada es siempre más eficiente que la gestión pública. No obstante, tal y como venimos comentando, esto solo es cierto en el caso de los mercados de competencia perfecta y con ciertas limitaciones, y en ningún caso es una verdad absoluta en el caso de los monopolios. Por otro lado, existe, una vez más, el problema de la concentración de poder. Efectivamente, los que se hacen con el control de las empresas privatizadas suelen ser quienes ya ostentan gran poder económico y, por lo tanto, tienen capacidad para invertir en la compra de un porcentaje elevado de acciones. Así, por ejemplo, no es de extrañar que los grandes bancos sean accionistas de referencia, así como fondos de inversión extranjeros. Pues bien, en esta tesitura, tampoco debe sorprendernos el que estos propietarios puedan influir en el ánimo de los políticos de turno, por ejemplo gracias a las denominadas "puertas giratorias", para conseguir una regulación favorable para sus empresas, de 
forma que puedan explotar su posición dominante en el mercado y evitar la competencia. De esta manera, lo que se acaba consiguiendo es una mayor concentración de poder económico y, por lo tanto, político, en unas pocas manos. $\mathrm{Y}$, paradójicamente, todo en aras de una mayor eficiencia.

Otro modelo de gestión que otorga un poder monopolístico a las empresas es el de las concesiones. Por ejemplo, para explotar una autovía. Una vez más, si bien el modelo de gestión podría en teoría funcionar correctamente, el problema lo encontramos en su implementación, cuando las empresas concesionarias tienen suficiente poder como para influir en las decisiones de los políticos y conseguir condiciones extraordinariamente favorables. Uno de los casos más extremos es el reciente rescate de las autovías radiales de Madrid, en las que el Estado ha tenido que asumir las pérdidas de la empresa concesionaria. Obviamente, se trata de una situación enormemente ineficiente e injusta, en la que las grandes empresas participantes solo podían obtener beneficios sin asumir ningún riesgo, situación totalmente desconocida en los mercados de competencia perfecta.

Al margen de los monopolios justificados por ser monopolios naturales, el Estado también puede intervenir y crear monopolios sin justificación alguna. Así podemos comprobar cómo los diferentes gobiernos procuran facilitar a sus correligionarios negocios ventajosos mediante las concesiones, como las de la Inspección Técnica de Vehículos, esta vez en el ámbito de las Comunidades Autónomas. No está en absoluto demostrado que la gestión pública fuera menos eficiente. $Y$ también se podría estudiar la posibilidad de abrir las ITV a la competencia. Lo que sí es evidente es que se trata de un negocio redondo para sus propietarios, dado que todos los vehículos están obligados a acudir y, además, las Fuerzas de Seguridad del Estado persiguen a los clientes que no acuden a su cita. También resulta sospechoso que la inspección difiera de una Comunidad Autónoma a otra, cuando se trata de temas de seguridad en los vehículos que posteriormente podrán circular por todo el país. Este hecho demuestra claramente que lo que se busca es crear artificialmente una clientela prisionera. Todo un chollo. No es de extrañar que muchos casos de corrupción aparezcan relacionados con este tipo de situaciones, en las que se otorga a una empresa una posición monopolística. Una vez más, la participación real del 
Estado difiere de lo que sería recomendable, con la consiguiente pérdida de bienestar para la ciudadanía.

En términos generales podemos concluir que cuando existen monopolios naturales, especialmente como consecuencia de redes de distribución con un coste muy elevado, lo más eficiente parece ser que es la gestión directa por parte del Estado. De esta forma se facilita la competencia entre las empresas que desean utilizar esas redes (telecomunicaciones, electricidad, gas, agua, carreteras, infraestructuras ferroviarias) sin que sea una empresa privada la que decida quién puede usar sus infraestructuras. En los demás casos, el papel del Estado debe ser siempre evitar situaciones que restrinjan la competencia y evitar el abuso de posiciones dominantes en el mercado.

\subsection{LOS BIENES PÚBLICOS}

Existen unos bienes con unas características peculiares que hacen que el mercado no los suministre, o los suministre en una cantidad insuficiente, por lo que el Estado tiene que intervenir en el mercado y producirlos directamente. Son los denominados bienes públicos como, por el ejemplo, el alumbrado público. Las principales características son que no hay un coste adicional a causa de que una persona adicional disfrute del bien, el beneficio del bien es indivisible y resulta complicado, cuando no imposible, impedir que todas las personas que lo deseen disfruten de ese bien.

En el caso del alumbrado público, en primer lugar, es obvio que produce una serie de ventajas en los ciudadanos, así que tiene sentido que haya un alumbrado público en las poblaciones. Por otro lado, una vez está en funcionamiento, su coste no aumenta si por la calle pasan 100 personas en lugar de solo 5, no hay un coste adicional. Y, además, es difícil evitar que una persona que pasa por la calle no se beneficie de ese bien. Por ejemplo, que cuando llegue una persona concreta a la calle se apaguen las luces.

Existen diversos ejemplos de bienes públicos. Un ejemplo típico es el de los faros. Pero también el de las calles y carreteras. O la defensa nacional y la 
seguridad ciudadana. O el servicio de meteorología. O la protección contra los incendios forestales. O una buena gestión pública. En todos estos casos, el que haya más o menos personas que los usen o se beneficien de ellos, dentro de un rango, no implica un mayor coste y, además, resulta difícil excluir a nadie de los beneficios que generan estos bienes. Por esta razón, lo razonable es que sea el Estado el que se encargue de suministrar dichos bienes y que se paguen entre todos mediante impuestos. Imaginemos cuán ineficiente sería que tuviéramos que pagar por utilizar cada tramo de calle o carretera. O que hubiera personas que no pudieran tener acceso a la previsión del tiempo. O dejar que se quemara un bosque y el incendio se extendiera a una ciudad.

La pregunta es, ¿por qué no producen las empresas privadas suficientes bienes públicos? Básicamente, si la exclusión no es posible, si todas las personas se benefician de estos bienes sin que sea posible excluirlos sin tener que asumir costes muy elevados, el sistema de precios del mercado no puede funcionar, la ley de la oferta y la demanda. La única forma de sufragar los costes de los bienes es obligar a todos a que contribuyan, mediante los impuestos, por ejemplo. Y eso sólo lo puede hacer el Estado. En un mercado convencional, el que quiere disfrutar de un bien debe pagar por él necesariamente, pero con los bienes públicos, por la característica de la no exclusión, este sistema no puede funcionar. Así que las empresas no tienen alicientes para producir bienes que serán disfrutados por personas que no les pagan. Lógicamente. Así nos encontramos con que la producción de bienes públicos por empresas privadas sería insuficiente.

Esta situación se debe al llamado "problema del polizón" y aparece relacionado con la imposibilidad de excluir a nadie de los beneficios que generan los bienes públicos. Imaginemos que no fuera el Estado sino las empresas privadas quienes tuvieran que proporcionar (y cobrar a los clientes que se dan de alta en el servicio) el alumbrado de las calles. Como todos los viandantes acaban beneficiándose de la luz de las farolas (seguridad vial, evitar actos de vandalismo, incluso menor ruido nocturno en el barrio), incluso los turistas, los ciudadanos no tienen ningún incentivo para pagar, por lo que no es posible que se genere un mercado. La premisa es "que paguen los demás, que yo me beneficio igual", puesto que todos nos beneficiamos de las externalidades positivas del servicio de alumbrado. Se llama problema del polizón, aunque 
podría denominarse problema del gorrón. Aún en el caso de que algunos ciudadanos estuvieran dispuestos a sufragar parte de los gastos a sabiendas de que otros muchos se aprovecharán de su generosidad, todo el proceso de reunir a los que pagarían voluntariamente y se repartirían el coste del alumbrado resultaría muy ineficiente.

Si no interviene el Estado, se generarán situaciones ineficientes o injustas, en las que unos pocos pagan y todos se benefician. $\mathrm{O}$, directamente, las empresas privadas no proporcionan el bien, puesto que su función es pensar en su beneficio particular, del que depende su supervivencia, y no en términos de beneficio social.

\subsection{LOS BIENES PREFERENTES}

Hasta este momento hemos tratado situaciones en las que el foco de la ineficiencia, la producción excesiva o insuficiente de un bien, se debía principalmente a las decisiones empresariales, siempre dentro de un comportamiento estrictamente racional. Pues bien, en el caso de los bienes preferentes, el foco se centra en los consumidores. Los bienes preferentes son aquellos que el Estado considera que los ciudadanos deben consumir necesariamente, pues generan externalidades positivas y evitan situaciones de extrema desigualdad. Por lo general, es la falta de información por parte de los ciudadanos o un comportamiento poco racional, el que les impulsa a no consumir estos bienes, por lo que el Estado debe actuar para evitar males mayores futuros que afectarán al resto de la sociedad y no exclusivamente a los que no tomaron la decisión correcta. Por otro lado, es importante resaltar que, si bien el Estado obliga a consumir dichos bienes preferentes, no tiene que ser el Estado necesariamente quien los suministre.

Un ejemplo de bien preferente es la educación obligatoria. Como sabemos, la formación de las personas incide directamente en su desarrollo y en sus posibilidades laborales futuras. Por lo tanto, dejar que sean los padres los que decidan si sus hijos o hijas van o no a la escuela (muchas veces la decisión depende del sexo de los vástagos o de las necesidades económicas familiares), 
no parece razonable. Se trata de decisiones que necesariamente van a determinar el futuro de los niños y no se pueden dejar en manos de unos padres irresponsables, egoístas o simplemente con pocos recursos económicos. Por otro lado, ya hemos comentado que la educación y la cultura generan una serie de externalidades positivas, por lo que toda la sociedad sale ganando con la escolarización obligatoria y, sensu contrario, pierde si hay capas de la población que no van a la escuela. Además, es probable que sean precisamente aquellos niños que más necesidad tienen de ir a la escuela los que se queden sin ir si se deja la elección en manos de los padres. Precisamente por esta obligatoriedad es razonable que la enseñanza obligatoria sea gratuita para todos.

Otro ejemplo es el de las pensiones. En España, por ejemplo, todos los trabajadores estamos obligados a cotizar a la Seguridad Social. Además, podemos recurrir a planes de pensiones privados. La obligatoriedad de la medida se debe a que, de ser algo voluntario, podría darse el caso de que algunas personas no ahorrasen de cara a su jubilación. Obviamente, en una sociedad avanzada como la nuestra, por mera compasión, no querríamos dejar totalmente sin recursos a esas personas mayores cuando se quedaran sin patrimonio por no haber ahorrado cuando debieron hacerlo y haberse gastado todo su dinero mientras los demás reducíamos nuestro consumo y nuestro nivel de vida. Pero, claro, si es público y notorio que el Estado se va a hacer cargo de aquellas personas que no ahorran, el incentivo para ahorrar disminuye. Así que una medida es obligar a que todas las personas contribuyan a la Seguridad Social, quieran o no. Esta contribución puede ser de forma directa al fondo de la Seguridad Social o bien a través de impuestos. Es decir, se trata de evitar que las personas, que no sabemos cuánto tiempo vamos a vivir ni en qué condiciones físicas, tomemos decisiones cortoplacistas y, en caso de no morirnos pronto, no seamos una carga para el resto de nuestros conciudadanos. Obviamente, dentro de esta línea de pensamiento, sigue siendo controvertido cuál debe ser la contribución de cada cual, cómo se debe articular dicha aportación y cuánto se debe recibir a partir del momento de la jubilación, así como cuándo debe tener lugar ese evento.

Por otro lado, si el Estado se compromete a velar por la salud de los ciudadanos, también se entiende que se exija a los ciudadanos que colaboren en sufragar 
dichos gastos, bien de forma directa a través de seguros de salud, bien de forma indirecta mediante el pago de impuestos.

Además, el hecho de que el Estado se vaya a comportar de forma compasiva con los ciudadanos que sufren ciertos accidentes o percances justifica que el Estado les obligue a tomar ciertas medidas paliativas. Así, puede obligar al uso del cinturón de seguridad en los coches o al del casco en las motos. Además, la pérdida de capital humano afecta a toda la sociedad. Otro ejemplo son las regulaciones sobre la construcción de edificios o la prohibición de construir en ciertos lugares, como barrancos.

No obstante lo expuesto, en ocasiones es posible que el Estado se extralimite en su celo por protegernos a nosotros y a la sociedad y se ponga a regular hasta los detalles más insignificantes, con el consiguiente coste para los ciudadanos en términos de tiempo y dinero y pérdida de libertad. Por otro lado, hay actitudes ciertamente paternalistas que pueden incluso esconder intereses ocultos de grupos de presión poderosos. Pensemos, por ejemplo, en la Ley Seca en los EEUU y cómo la prohibición de beber alcohol promovida por personas piadosas y con celo religioso provocó la aparición de mafias, sin conseguir disminuir el consumo de alcohol, aunque sí aumentar el número de muertes violentas y de políticos corruptos. Al legalizarse de nuevo el alcohol, desapareció un gran negocio. Reflexione el lector.

\subsection{FALLOS EN LA INFORMACIÓN}

Como hemos comentado, uno de los requisitos fundamentales de los mercados de competencia perfecta es la existencia de información. Tanto los productores como los compradores deben disponer de toda la información relevante sobre los productos y los precios. De esta manera es posible comparar los diferentes productos, sus características principales y sus precios sin que esto suponga perder tiempo ni dinero. También hemos visto cómo las empresas, en su afán de huir de la jaula que supone para ellas la competencia perfecta, buscan por diversos medios evitar la comparabilidad de los productos, lo que en ocasiones implica no ofrecer información relevante sobre los mismos. 
En este contexto, el Estado debe intervenir para obligar a las empresas a que den cierta información o para que los productos cumplan con unos requisitos mínimos de calidad. Podríamos pensar que la propia competencia obligaría a las empresas a facilitar toda la información necesaria, so pena de que los consumidores dejaran de comprar sus productos, pero esto no es así. Además, aunque se diera el caso, mientras tiene lugar ese proceso se producen ineficiencias que pueden tener consecuencias graves. Por no mencionar que en muchos casos nos encontramos con mercados alejados de la competencia perfecta, por lo que las empresas no tienen incentivos para dar información salvo que se les obligue. Es más, en muchos casos luchan para evitar tener que dar cierta información.

Tal vez el caso en el que es más importante contar con información contrastada es en lo relativo a la seguridad del consumidor. Por lo general, no es algo que nos preocupe, puesto que, precisamente, sabemos que el Estado se ocupa de que los productos que consumimos no sean peligrosos para nuestra salud. Se destinan muchos recursos a esta finalidad. $Y$, en principio, nos fiamos de la decisión de los funcionarios. No tendríamos el mismo nivel de confianza si fueran las mismas empresas implicadas las que ofrecieran la información, sin ser examinadas posteriormente por organismos estatales. Pensemos en los escándalos de contaminación de vehículos diesel y de cómo se nos ha engañado durante años a los consumidores, incluso a pesar del control de diversos Estados. $Y$ es que, como venimos diciendo, cuando un lobby es muy poderoso puede conseguir que las decisiones políticas, disfrazadas de decisiones técnicas, se tomen para favorecer sus intereses.

Si bien cada cierto tiempo salen a la luz escándalos de este tipo, en términos generales podemos fiarnos de la intervención estatal en pro de nuestra seguridad. Así, nos aporta una información de vital importancia que el mercado no podría darnos con el mismo nivel de confianza: que los productos que se comercializan son seguros. Esta seguridad es fundamental en todos los ámbitos, y el Estado interviene regulando los más diferentes aspectos. Por ejemplo, que los juguetes no pueden llevar pintura de plomo. O que las construcciones no deben emplear amianto. Algunos productos, como los medicamentos, deben pasar un proceso antes de ser autorizada su comercialización. Y se controla que 
no se pueda vender como medicamentos productos que no lo son, como los productos homeopáticos. También se controla la seguridad de los productos que comemos y bebemos, que son objeto de control fitosanitario. En general, como consumidores es importante tener la certeza de que no nos vamos a envenenar. Obviamente, toda esta actuación estatal ( $y$, ciertamente, de algunas asociaciones de consumidores) nos evita tener que investigar nosotros mismos acerca de la seguridad y eficacia de los productos que consumimos. Además, se garantiza que la información que aportan los productores acerca de sus productos sea cierta. Esto implica una ganancia en transparencia y en información muy grande. Pero, lo más importante es que, en realidad, la seguridad del consumidor no depende de que pueda leer y comprender las especificaciones técnicas de los productos y los prospectos, lo que le llevaría horas y horas. Directamente, se puede fiar de que los productos que se comercializan no son dañinos para su salud.

Volviendo al tema de la información sobre los productos, el Estado establece unas normas sobre el etiquetado, que es la principal fuente de información para muchos consumidores y que les ayuda a elegir si finalmente compran un producto u otro. Esta información va cambiando con los años y depende también de qué información resulta relevante para los consumidores. En muchas ocasiones, las empresas se oponen a aportar cierta información y no lo hacen si no se ven obligadas a ello. A veces, consiguen doblegar a los reguladores y se salen con la suya. Así, por ejemplo, en EEUU los productos alimenticios no deben especificar si se han elaborado con transgénicos, si bien esta información es relevante para muchos consumidores. De esta manera, los consumidores no pueden elegir. Otras veces no se dice la procedencia de las diversas partes que componen un producto, y la información se limita al lugar donde se ha ensamblado o a la nacionalidad del importador.

Pero, en términos generales, el etiquetado nos permite obtener información sobre aspectos importantes como, en el caso de los alimentos, los ingredientes, información nutricional, fecha de caducidad, origen etc. En los últimos años también se informa sobre el tipo de producción, si es ecológica y en qué grado, lo cual es importante para un número cada vez mayor de consumidores.

En cuanto a productos tecnológicos, como coches o electrodomésticos, el Estado establece un periodo mínimo de garantía, lo que de por sí ofrece cierta 
información al consumidor, quien sabe que adquiere un producto con una calidad mínima garantizada, con independencia de que luego pueda durar más.

En otros casos, como en los productos financieros, es obligatorio que el coste de los préstamos y la rentabilidad de las inversiones de calcule siempre de la misma manera, para que sean comparables, en términos de tasa anual equivalente (TAE).

En los últimos años los requerimientos de información a las empresas para aumentar la transparencia de su actuación se están centrando en internet. Así, una normativa europea ha obligado recientemente a los proveedores de aplicaciones a que especifiquen claramente qué datos extraen del teléfono y cómo los emplean. $Y$ han salido a la luz casos realmente interesantes, como el de la aplicación de la Liga Profesional de Fútbol, que utilizaba su aplicación para espiar a los usuarios. Ahora solo lo hace si se le da el consentimiento expreso, no como opción por defecto.

Un mercado en el que existen fallos en la información es el mercado laboral. Las empresas necesitan contratar personal con ciertas capacidades concretas y no es en absoluto eficiente que tengan que dedicar mucho tiempo en conocer la preparación de los candidatos. En este caso, el Estado facilita a las empresas la obtención rápida de información mediante la creación de unos estándares, cuales son los diferentes niveles de estudios y las diversas titulaciones. Así, gracias a la intervención estatal en el sistema educativo, una empresa ya sabe qué puede esperar, con cierto grado de variación, de un ingeniero informático, un licenciado en derecho, un graduado en biología o una persona con estudios de la ESO. Simplemente mirando el título. Así, a la hora de ofrecer puestos de trabajo puede dirigirse directamente al grupo o grupos que considere más cualificados, reduciendo los costes del proceso de selección.

Como se puede comprobar, el papel del Estado en aras de facilitar la información en los mercados es de gran importancia y facilita en gran medida la existencia misma de los mercados, así como la protección de los consumidores, fomentando al mismo tiempo la competencia. 


\section{5. MERCADOS INCOMPLETOS}

Hablamos de mercados incompletos cuando el mercado no es capaz de suministrar un bien o un servicio a pesar de que el precio que están dispuestos a pagar los consumidores por él es mayor que su coste de producción. Esta situación se da principalmente como consecuencia de asimetrías de información y se da especialmente en algunos mercados de seguros. Así, el Estado ofrece a los agricultores seguros agrarios porque las compañías de seguros no ofrecen productos para proteger a los agricultores frente a las malas cosechas, entre otros motivos, por el riesgo que esa cobertura conlleva debido a la escasez de información. Las aseguradoras tampoco suelen ofrecer seguros de desempleo. En este caso, además, queda patente otro problema, denominado de selección adversa, que postula que las aseguradoras querrían asegurar a aquellas personas con pocas probabilidades de perder sus empleos, pero éstos por su parte, sabedores de que es poco probable que lo pierdan, preferirán asumir ellos ese riesgo y no acudir a un seguro. Por otro lado, las personas con altas probabilidades de quedarse en el paro sí que querrán asegurarse, pero las empresas aseguradoras no los aceptarán.

La falta de información acerca del riesgo que se asume también genera mercados incompletos en el ámbito de los préstamos y dificulta además determinar la prima de riesgo a cobrar en forma de tipo de interés por dichos préstamos. Así, en ocasiones, el Estado interviene ofreciendo préstamos en condiciones especiales a colectivos que, de otra manera, quedarían privados de fuentes de financiación. Un ejemplo pueden ser los créditos a la exportación para las pequeñas y medianas empresas.

Finalmente, en ciertos casos la información perfecta también puede ser un problema y hacer desaparecer un mercado por completo. Pensemos en lo que ocurriría en el mercado de los seguros médicos si, debido a los avances de los conocimientos genéticos, se supiera con certeza de qué y cuándo va a enfermar una persona. 



\section{ESTABILIZACIÓN MACROECONÓMICA Y CRECIMIENTO ECONÓMICO}

En los capítulos anteriores hemos definido cuál debiera ser la misión fundamental del Estado, que es velar por la creación de un entorno favorable para todos los ciudadanos, y por qué debe actuar e intervenir en la economía para alcanzar ese objetivo. Si bien la mano invisible del mercado puede ser muy eficiente en numerosas ocasiones, hemos comprobado que existen una serie de problemas que hacen que el mercado de competencia perfecta no sea necesariamente compatible con un crecimiento económico sostenible, ni equitativo ni ecológico. Además, son muchos los mercados imperfectos en los que el Estado debe intervenir para aumentar la eficiencia.

Esta tercera parte del libro se dedica a las formas de actuación del Estado, una vez hemos visto que esa actuación es necesaria en ciertas circunstancias. Así, este capítulo se dedica a las políticas de estabilización económica, el siguiente a las políticas de redistribución de la renta y el último a las políticas de asignación de recursos por el Estado. Se comentarán diferentes opciones de actuación del Estado, subrayándose cómo las diferentes posibilidades tienen necesariamente una carga política, pues influyen de forma diferente en los distintos actores de la economía.

Tal y como venimos reiterando, incluso el mercado de competencia perfecta presenta fallos que hacen que el Estado intervenga con el fin de garantizar la asignación eficiente de los recursos económicos. No se trata siquiera de una cuestión de equidad, sino directamente de eficiencia. Uno de estos fallos es que el mercado genera necesariamente crisis económicas. Es decir, el mercado crea problemas de inestabilidad económica que, además, no es capaz de resolver por sí mismo. Un caso paradigmático son las burbujas financieras, donde resulta obvio que los recursos financieros se asignan en un mercado no regulado de forma totalmente ineficiente y ocasionan graves daños a la economía y la sociedad en su conjunto. 
El papel del Estado, por lo tanto, consiste en ayudar a la economía a capear las recurrentes recesiones económicas, suavizando los ciclos económicos, frenando a la economía en algunos momentos, estimulando el crecimiento económico en otros y evitando la creación de burbujas en la economía.

Para alcanzar el objetivo de la estabilidad económica, el Estado dispone de diversos instrumentos de política fiscal, política monetaria y control de la balanza de pagos. Actuando sobre estos instrumentos el Estado busca controlar la evolución del PIB. Por lo general, la estabilidad económica se monitoriza con el PIB, así que es ésta la variable macroeconómica de mayor importancia. El resto de variables macroeconómicas, como la inflación, el empleo, los tipos de interés o el tipo de cambio son también importantes para analizar aspectos económicos específicos. Huelga decir que todas estas variables están muy relacionadas.

Desde la perspectiva que se defiende en este ensayo y como comentaremos más adelante, controlar la evolución de estas variables macroeconómicas, si bien es importante, no deja de ser sino un medio y nunca debe ser un fin en sí mismo, que es en lo que se ha convertido en la actualidad. Por ejemplo, un aumento de la producción de bienes y servicios en un país, es decir, un aumento del PIB, puede que no se reparta entre la toda la población, sino que el mayor tamaño de la "tarta" quede en manos de un grupo reducido de personas, por lo que no mejorará la calidad de vida de los demás ciudadanos. Además, si el aumento del PIB se ha conseguido mediante la mayor producción de contaminación, la situación de muchas personas, en vez de mejorar es posible que empeore, precisamente por culpa de ese mayor PIB.

A continuación vamos a tratar someramente las diferentes políticas de estabilidad de que dispone el Estado en teoría. Pero antes de comenzar, hay que tener en cuenta que muchos aspectos de la macroeconomía son muy discutidos entre los economistas, que no se ponen de acuerdo sobre las bondades y deficiencias de las políticas fiscales y las políticas monetarias. Además, la eficacia de las políticas depende de la situación económica concreta. Analizar todos los pormenores requeriría al menos un curso de macroeconomía. Aquí me limitaré a explicar las ideas más básicas de cómo funcionan estas 
políticas que, de facto, emplean los Estados para controlar la actividad de sus economías.

\subsection{LA POLÍTICA FISCAL Y EL DÉFICIT PÚBLICO}

Es curioso que las voces que desde diversos sectores empresariales defienden que el Estado no intervenga en la economía, elimine regulaciones y deje libertad a los mercados, se apaguen cuando llega una crisis económica y cambian su discurso para pedir que el Estado actúe y les ayude a capear el temporal. Pero, ¿qué puede hacer el Estado, concretamente el Gobierno y las diversas Administraciones Públicas, para reflotar la economía? Bien, veamos cómo se puede utilizar la política fiscal, que es el intento del Estado de influir sobre la economía modificando sus propios gastos e ingresos.

Recordemos que, en principio, nuestro modelo económico actual se basa en que la economía debe estar en continuo crecimiento, cuanto más rápido, mejor. Si el crecimiento se ralentiza o incluso se decrece, entonces nos ponemos nerviosos. El crecimiento económico se mide mediante el Producto Interior Bruto, el famoso PIB, que mide la producción de bienes y servicios en un país. Suponemos que cuanto más se produzca, mejor. Para calcular el PIB de un país, que no es tarea sencilla, se suma el consumo de las familias, la inversión de las empresas, las compras de bienes y servicios del sector público y las exportaciones netas. Así sabemos lo que se ha producido en el país durante un periodo concreto utilizando el llamado enfoque del gasto. Por lo tanto, si el Gobierno quiere aumentar el PIB, simplemente debe influir sobre estas variables: consumo de las familias, inversión de empresas, exportaciones y, la más fácil, compras del sector público. Lo malo es que no es tan sencillo como parece. Para empezar, porque la disminución del PIB se puede deber a un shock de oferta o a un shock de demanda, lo que hace que la situación, digamos, la "enfermedad" de la economía sea muy diferente, por lo que los remedios también lo serán y puede que la política fiscal no sea la más indicada. La casuística que acompaña la variabilidad del PIB es muy, pero que muy diversa. 
En cualquier caso, a los efectos de este libro, vamos a poner un ejemplo sencillo en el que la política fiscal sí que podría ser útil (si bien hay economistas que defienden, en casos similares al del ejemplo, la aplicación de una "regla fija" que consiste en no tomar ninguna medida, no actuar y dejar que el mercado se estabilice él solo). Pensemos en una situación en la que la economía se esté desacelerando y puede que entre en recesión. Para evitar esa recesión, el Gobierno puede aumentar la compra de bienes y servicios (o reducir impuestos, o dar más subvenciones...), lo que se denomina una política fiscal expansiva. Este aumento de las compras gubernamentales supone una inyección extra de dinero en la economía, por lo que genera a su vez un incremento del consumo y de la inversión y el PIB aumenta, si bien este aumento puede (o no) venir acompañado de una subida del nivel de precios, es decir, de inflación. Digamos que este es el efecto más inmediato. Más tarde, el aumento del PIB provoca un aumento de los tipos de interés (en el caso de que aumente la inflación, ya que el alza del nivel de precios genera una disminución de la oferta monetaria real), que hace que bajen el consumo y la inversión, lo que hace que el PIB decrezca. Estos efectos, denominados de "segunda vuelta" son más débiles que los efectos inmediatos de "primera vuelta". En fin, se puede observar que se trata de un proceso bastante complejo, y eso que se ha presentado un ejemplo muy simplificado. En cualquier caso, podemos comprobar que son muchas las variables económicas que se ven afectadas por un aumento del gasto público, que además reaccionan en sentidos a veces opuestos y en diferentes momentos del tiempo. Así, aunque podemos saber con ciertas garantías qué cambios pueden desencadenar las diferentes políticas económicas, la política fiscal en el caso que nos ocupa, no podemos saber a ciencia cierta ni la intensidad en la que se van a ver modificadas las variables macroeconómicas ni tampoco cuándo se van a ver afectadas, es decir, si los cambios en la economía van a ocurrir en unas semanas o muchos meses. $Y$ es que la realidad es extraordinariamente compleja y los modelos económicos son limitados, aunque tienen en consideración numerosos factores, como los diferentes multiplicadores económicos o las expectativas de los agentes económicos.

Sea como fuere, no podemos predecir con seguridad cuánto ni cuándo va a aumentar el PIB como resultado de una política económica concreta, sea fiscal 
o monetaria. Y mucho menos podemos decir cómo va a afectar ese aumento del PIB a los diferentes grupos sociales y su calidad de vida.

En el ejemplo, hemos hablado de una política fiscal expansiva, que implica aumentar el gasto. Se trata de aumentar el gasto del Gobierno sin aumentar sus ingresos via impuestos, pues el efecto de la segunda medida podría contrarrestar el de la primera, complicando mucho el ejemplo. Pues bien, si el Gobierno debe gastar más sin recaudar más, ¿de dónde sale el dinero? Este es uno de los principales problemas de la política fiscal expansiva, que genera déficit. ¿Y por qué es malo el déficit? Bueno, en realidad, eso de que el déficit es malo es muy matizable. El déficit es malo depende de para quién. Igual que la inflación. O la depreciación de la divisa. O los tipos de interés elevados. O el desempleo. En cada situación hay personas y empresas que se benefician y otras que salen perjudicadas.

No obstante, hay un aspecto del déficit y de la deuda pública que se nos suele olvidar y sobre el que invito a la reflexión. Me refiero a su papel en los mercados financieros. Imaginemos que los Estados siguen políticas de presupuesto equilibrado, sin déficit, y eliminan la deuda pública. Imaginemos también, en este contexto, que se eliminan en los países europeos las pensiones públicas obligatorias y debemos invertir en fondos de pensiones privados. En estas circunstancias, habría mucho más dinero para invertir en activos financieros, pero muchos menos activos financieros donde invertir, teniendo en cuenta que la deuda pública global en 2019 era de unos 50 billones de dólares americanos (USD) y siempre representa un porcentaje muy elevado del mercado mundial de renta fija. Esto ocasionaría una subida enorme del valor de los activos financieros restantes a corto plazo que no estaría soportado por su valor fundamental, generando una enorme volatilidad en los mercados a medio plazo. Es como si, de pronto, todos los actores famosos de Hollywood quisieran comprarse un apartamento en Denia y, además, un grave incendio hubiera destruido para siempre la mitad de la ciudad. Por lo tanto, hay que mirar con recelo las propuestas de quienes piden simultáneamente eliminar la deuda pública y eliminar las pensiones públicas obligatorias, pues no están mirando el cuadro completo y, posiblemente, esperan obtener ganancias en ese proceso. 
Y ahora sigamos con el caso del déficit. El déficit se produce cuando el Gobierno gasta más de lo que ingresa. Entonces emite deuda pública y consigue el dinero, que deberá devolver con intereses. Si al año siguiente el Gobierno vuelve a tener déficit, la deuda va aumentando. Y, lógicamente, cuanto mayor sea la deuda, mayor el lastre de devolución de ésta. Llegados a este punto, es fundamental ver quién compra esa deuda pública. Antiguamente, lo habitual era que el Banco Central del país adquiriera la deuda, lo que es equivalente a decir que el Gobierno imprimía billetes, generando inflación. Pero a cambio de los problemas de la inflación, que no tienen por qué ser necesariamente graves (dependerá del crecimiento económico generado por la política fiscal expansiva), se evitaba deber dinero a nadie y el coste de los intereses. Hoy en día los Bancos Centrales son independientes, por lo que la solución anterior no siempre es factible y, en el caso del BCE está estrictamente prohibida (lo que ocasionó a Grecia, España y otros países serios problemas durante la llamada crisis del euro que comenzó en 2011), por motivos políticos, obviamente, pues otros países sí que permiten que el Banco Central adquiera la deuda emitida por el Gobierno de la nación. En el caso español, la opción que le queda al Gobierno es endeudarse. Esta opción, dependiendo de las circunstancias, también puede generar inflación. Además, si la deuda total es elevada, es relevante conocer quién ha comprado dicha deuda, si son inversores nacionales o extranjeros, aunque es una problemática en la que no vamos a entrar, y cómo el pago de la deuda supone en realidad una redistribución de la renta. Por otro lado, el déficit crea un "efecto expulsión", pues la deuda pública compite con la deuda privada para captar recursos financieros, lo que encarece el coste de la deuda privada y puede reducir la capacidad de financiación en el mercado de las grandes multinacionales privadas.

Uno de los principales problemas reales es que el recurso del déficit no se emplea solo cuando hay recesiones con el fin de realizar políticas fiscales expansivas de corte keynesiano (bajar impuestos y aumentar gastos), sino que en muchas ocasiones los déficits son una constante, aunque son mayores en periodos de crisis. Es en estas circunstancias cuando suelen surgir los problemas. Así, un Estado necesitado de dinero para cubrir el déficit de un año concreto debe acudir a los mercados financieros a pedir financiación. Y los mercados financieros pueden negarse a dar dicha financiación, es decir, pueden 
no querer comprar la deuda del Estado. En tales circunstancias, ese Gobierno debe, o no incurrir en el déficit, con las consecuencias que ello tiene para la economía nacional afectada por la crisis económica, o acudir al Fondo Monetario Internacional (FMI) o instituciones similares. Ante la necesidad imperiosa de dinero, estos organismos internacionales pueden poner condiciones draconianas para garantizarse el cobro de la deuda o simplemente aprovechan la coyuntura para imponer su ideario político. Estas condiciones pueden ir desde exigir medidas para atajar el déficit relacionadas con el recorte de gastos y la subida de impuestos, hasta cambios legislativos relacionados con el mercado laboral o las instituciones financieras o incluso la reforma de la Constitución del Estado. Frente a la opinión pública, dichas medidas se justifican por ser necesarias para evitar el malvado déficit, como si el déficit fuera el objetivo a batir. En el caso del ejemplo que hemos expuesto, el déficit era necesario para evitar la recesión económica, mientras que las medidas de austeridad propuestas por el FMI agravan necesariamente la crisis. Por otro lado, cuando llega una recesión comienzan a actuar los denominados estabilizadores automáticos, como el impuesto sobre la renta (cuya recaudación disminuye) o las prestaciones por desempleo (cuyo gasto aumenta), aumentando así el déficit público. Parece claro que no es razonable generar déficit año tras año, aumentando constantemente la deuda, especialmente en contextos de baja inflación, pero ¿qué nivel de deuda pública es el máximo tolerable? ¿el equivalente al $234 \%$ del PIB como Japón, el 134\% como Italia, 109\% como EEUU, 97\% como España, $60 \%$ como Alemania, 48\% como Armenia (todos estos datos de 2019) o el 35\% como España en 2007?

Llegados a este punto debe haber quedado claro que ni la generación de un déficit reiterado y ni la lucha a cualquier precio contra un déficit puntual son necesarias desde la ortodoxia de la teoría económica. Es muy discutible que un Estado tenga que reducir el déficit precisamente durante una recesión. Por otro lado, un Estado con una deuda elevada y que genera varios déficits abultados consecutivos se verá más expuesto a que los mercados no financien el nuevo déficit.

Dicho esto, debemos acabar de pintar el cuadro. Ya hemos comentado que la economía es cíclica, con periodos de crecimiento y con recesiones. Hemos 
puesto el ejemplo de la actuación del Estado en el caso de una recesión, mediante una política fiscal expansiva. ¿Cómo debiera actuar el Estado en los momentos de bonanza económica? Pues, según el enfoque expuesto, reduciendo sus compras y aumentando impuestos, de forma que generaría un superávit con el que afrontar los periodos malos. De esta manera se ralentizaría el crecimiento económico y se frenaría la inflación. Pero las políticas económicas implementadas efectivamente en tiempos de crecimiento no podrían distar más de la teoría. Por lo general, los políticos y el resto de agentes económicos se acuerdan de Keynes en las recesiones, pero se olvidan de él cuando las cosas van bien. Vamos, como le pasa a Santa Bárbara, de la que solo nos acordamos cuando truena.

Ahora debemos reflexionar acerca de quiénes son los beneficiarios de las diferentes políticas económicas, pues serán ellos quienes las defiendan. ¿Quién se beneficia del déficit? ¿Y quién se beneficia de las medidas de austeridad? La respuesta depende de cada caso concreto. Además, uno puede defender la austeridad "para los demás", que se aprieten los otros el cinturón pero que a mí me siga ayudando el Estado. Veamos el caso español.

Mientras se hinchaba la burbuja inmobiliaria, el Estado español, las diferentes Administraciones Públicas, lejos de seguir las prescripciones keynesianas para frenar el crecimiento económico, se dedicaron a aumentar el gasto y a reducir los ingresos públicos. En este sentido, se lanzaron a una vertiginosa actividad de construcción de infraestructuras y actividades megalómanas varias, que en muchos casos no tenían ningún sentido y constituían un claro despilfarro de recursos públicos. Además, más tarde hemos sabido que en no pocas ocasiones esta actividad estaba ligada a tramas de corrupción que involucraban tanto a grandes como a medianas empresas. Por otro lado, se bajaron los impuestos a las empresas, saliendo especialmente beneficiadas las grandes multinacionales. Durante todo el periodo, ninguna voz se alzó para criticar estas políticas económicas llevadas a cabo por partidos de diferente signo político. Y eso que estas políticas no se sustentan en ninguna teoría económica. En cualquier caso, hay que decir que el déficit se controló y se consiguió reducir la deuda pública de forma muy notable, hasta el $35 \%$ del PIB, casi la mitad que Alemania en aquél momento. 
Cuando la burbuja estalló y llegaron las vacas flacas, sí que se pidió al Gobierno una política de demanda expansiva. Ésta llegó en forma del Plan E, que inyectó muchos millones a las empresas constructoras, precisamente las que habían generado las burbujas, y se gestionó a través de los Ayuntamientos, precisamente quienes habían dado muestras de niveles de despilfarro y mala gestión sin precedentes. Esta política, unida a los estabilizadores automáticos (menor recaudación por impuestos, mayor gasto en prestaciones por desempleo) y debido al rescate con dinero público de numerosas entidades financieras, tuvo como resultado el crecimiento continuado del déficit y, por ende, la emisión de deuda pública. Y entonces se dijo que los españoles habíamos vivido por encima de nuestras posibilidades y tocaba apretarse el cinturón. Llegó la Troika (representantes del FMI, el BCE y la Comisión Europea) para, a cambio de liquidez, controlar que se tomaban medidas correctoras del déficit. Las medidas concretas que se tomaron fueron dirigidas a la reducción del gasto en pensiones, del gasto por prestaciones de desempleo y del gasto en personal funcionario. También se subió el IVA, que es un impuesto indirecto regresivo que afecta a todos los ciudadanos y relativamente más a los que tienen menos ingresos.

Sin entrar en mayor detalle, podemos ver quién se ha visto favorecido por las políticas del Estado. Durante el periodo de crecimiento, el dinero público fluía directamente a las empresas ligadas a la construcción y a las entidades financieras. Además, las grandes empresas se beneficiaban de reducciones de impuestos de gran calibre. Al llegar la crisis, los que sufren el impacto son los ciudadanos de a pie, especialmente los de menos recursos, que ven cómo las prestaciones sociales recibidas disminuyen y los impuestos a pagar aumentan, mientras que la recaudación del Impuesto de Sociedades a las grandes empresas apenas aumentó, destacando el caso de la banca. Por otro lado, con la excusa de conseguir dinero y paliar el déficit público, se ofreció una amnistía fiscal, que luego fue declarada inconstitucional, siendo notable el que aún no se haya publicado la lista de personas que se acogieron a dicha amnistía. Y luego está el rescate de la banca, pagado de forma directa e indirecta por los ciudadanos, que ha beneficiado principalmente a sus acreedores extranjeros, como explico en el libro "Participación Ciudadana, Democracia y Crisis Económica". Mencionar en este sentido que en países europeos como Alemania 
y Francia también se decidió rescatar a la banca nacional, con la diferencia frente al caso español de que los bancos rescatados han devuelto al Estado el dinero del rescate más intereses, mientras que en España no se va a reclamar dicha devolución, siendo, por tanto, un regalo de los ciudadanos a dichas empresas.

En resumidas cuentas, vemos cómo en muchas ocasiones el Estado actúa de forma tal que magnifica la inestabilidad económica. Además, cuando toma medidas coherentes con la teoría económica, estas medidas recaen sobre unos agentes económicos, mientras que no afectan a otros. Normalmente las medidas, digamos, "favorables", caen sobre unos grupos de presión y los recortes recaen en otros grupos que no son capaces de presionar tanto a los decisores políticos. De esta manera tiene lugar una reasignación de los recursos económicos que puede favorecer la concentración de poder en unas pocas manos, gracias a la actuación del Estado.

En cualquier caso, debe quedar claro que no se puede defender ninguna política económica por ser la única opción posible, o la única defendida por la teoría económica. Siempre existen numerosas opciones y la elección de una u otra dependerá de la ideología política del decisor. A la hora de fomentar el aumento de la demanda agregada, es decir, de hacer crecer el PIB, se puede decidir entre aumentar el gasto en trenes de alta velocidad o construir hospitales, por ejemplo. $Y$ cuando se trata de bajar los impuestos, se pueden bajar a las grandes empresas o a las personas con mayor patrimonio o se puede reducir el IVA de los productos de higiene femeninos. La política economía nunca es "neutral" y mucho menos "apolítica". No existe una "tecnocracia" carente de ideología.

Todas estas acciones del Estado se justifican en la necesidad de que el Estado intervenga en la economía para lograr la estabilidad que, recordemos, se mide en términos de PIB. Pero, si pensamos que el fin último es el bienestar de los ciudadanos, de las personas, se pone de manifiesto que muchas de estas políticas son inadecuadas y responden directamente a los intereses de ciertos grupos de presión, nacionales o extranjeros.

La política fiscal es la única herramienta a nivel macroeconómico que tiene España en la actualidad, si bien vemos que dentro de unas limitaciones, pues la 
Unión Europea controla el déficit y la deuda pública, que no deben pasar ciertos niveles. De hecho, es la UE la que controla las otras herramientas de estabilidad económica, relacionadas con la política monetaria y la balanza de pagos.

\subsection{LA POLÍTICA MONETARIA Y LA SUPERVISIÓN BANCARIA}

Otra forma que tiene el Estado de influir en el devenir económico es a través de la política monetaria, es decir, controlando la cantidad de dinero en circulación en la economía (la oferta monetaria) y los tipos de interés. Es importante destacar que existen controversias entre dos escuelas económicas, "keynesianos" y "monetaristas", en cuanto a la eficacia de la política fiscal y la política monetaria. En su vertiente más extrema, los keynesianos niegan la influencia de la oferta monetaria sobre la demanda agregada, es decir, postulan que ésta no sirve como herramienta de estabilización económica, y lo mismo opinan los monetaristas extremos acerca de la política fiscal. En caso de que ambos tuvieran razón en este extremo, ni la política fiscal ni la monetaria serían útiles, y nos encontraríamos en una situación en la que la mejor opción sería la no intervención del Estado a nivel macroeconómico. Por lo general, hoy en día se acepta que ambas políticas son útiles, dependiendo, eso sí, de cómo afectan a la inversión las modificaciones de los tipos de interés. Según el caso, será más conveniente aplicar una u otra política económica, siendo por lo general conveniente una coordinación entre ambas políticas.

Los tipos de interés influyen en el crecimiento del PIB principalmente a través de la inversión y también a través del consumo. Cuando los tipos de interés son bajos, las empresas se endeudan más para financiar inversiones productivas y los consumidores también recurren al crédito para realizar sus compras, haciendo así que el PIB aumente. Como contrapartida, este aumento del PIB puede generar inflación. En realidad, es el crecimiento del crédito el que, al aumentar la masa monetaria, si no aumenta el PIB en la misma proporción, hace que haya más dinero para comprar los mismos productos, por decirlo de una 
manera sencilla, lo que hace que los productos se encarezcan, lo que significa que haya inflación. Para frenar la inflación, el Banco Central intenta controlar la masa monetaria con diferentes instrumentos, siendo la más habitual la monitorización de los tipos de interés a través del mercado interbancario en sus múltiples modalidades, esperando que los bancos transmitan las variaciones de los tipos de interés a sus clientes, si bien también dispone de otras opciones menos ortodoxas. Así como el Gobierno, tal y como hemos comentado, suele ser reticente a aplicar la política fiscal restrictiva en periodos de prosperidad, por lo general los Bancos Centrales, con un alto grado de independencia del Gobierno, sí que aumentan los tipos de interés en el caso de considerar que la economía se está "recalentando" con tensiones inflacionarias. De esta manera, se frena el crecimiento económico, lo que evita la inflación pero influye negativamente en la evolución del PIB y, consecuentemente, en el empleo. No obstante, unos tipos de interés elevados no son necesariamente negativos para todos, pues benefician a los ahorradores y a los prestamistas, que obtienen réditos más elevados. Además, estos son los colectivos que más pierden con aumentos inesperados de la inflación.

Una vez más, vemos que las decisiones de política económica no afectan de igual manera a todos los agentes económicos, por lo que no se puede decir que las decisiones de política monetaria sean "apolíticas" o exclusivamente "técnicas". Esto es así incluso en el caso del BCE, cuya única misión es velar por el control de la inflación. La propia definición de la misión del BCE, centrado en el control de la inflación, y los instrumentos de los que está dotado ya definen per se una visión política, frente a la misión de la Reserva Federal (FED) americana que junto al control de la inflación tiene asignado el velar por la situación macroeconómica en términos generales.

Dado el papel que tiene el sistema bancario como generador de inflación, los Bancos Centrales son también los encargados de supervisar y controlar la actuación de los bancos. Los bancos son elementos clave en la economía, pues realizan algunas funciones de gran importancia, como la financiación a empresas y consumidores o facilitar las transferencias monetarias, entre otras. Es importante destacar que un sistema bancario que cumpla correctamente con su cometido es de gran ayuda para la economía. Por otro lado, los bancos pueden 
generar gran inestabilidad en el sistema, principalmente por dos motivos: Primero, porque se dedican a invertir los fondos depositados por los ciudadanos y las empresas. Segundo, porque generan inflación en la medida en que otorgan préstamos. Además, las quiebras bancarias pueden generar un efecto dominó que sume a la economía en el caos y obliga al Estado a intervenir. Esto ocurrió, por ejemplo, en la famosa crisis de 1929, al igual que en la más reciente de 2008 , por citar dos casos muy conocidos, aunque existen muchísimos más, y es que las quiebras bancarias son bastante habituales, aunque no lo parezca. Puesto que el Estado tiene que intervenir en numerosas ocasiones en el caso de la quiebra de bancos para rescatarlos, como hemos tenido la ocasión de comprobar recientemente, parece lógico que regule su actuación para limitar el riesgo de quiebra. Existen muy diversas medidas de control de la actividad financiera que se pueden llevar a cabo, si bien el empleo de estas medidas va cambiando a lo largo del tiempo. Por ejemplo, se puede limitar el tamaño de los bancos, de forma que la quiebra de uno o varios bancos nunca pueda suponer un riesgo para todo el sistema. También se puede limitar la actividad bancaria, de forma que existan diferentes tipos de bancos en función del tipo de inversiones que puedan hacer o los tipos de productos que puedan ofrecer a sus clientes. Por ejemplo, en EEUU después de la crisis de 1929 se estableció una férrea diferenciación entre la banca minorista, que era en la que los ciudadanos depositaban sus ahorros y ofrecía básicamente préstamos al consumo e hipotecas, y la banca de inversión, dirigida a clientes acaudalados y empresas. También se puede utilizar el denominado coeficiente de caja, actualmente en desuso, o un coeficiente de reservas y un coeficiente de capital o de solvencia, como hace la normativa actual europea, por ejemplo. En definitiva, existen multitud de opciones para controlar la actividad bancaria, regulando tanto la obtención de fondos como su inversión.

Lo malo de la regulación es que impone controles y, lógicamente, a nadie le gusta que lo controlen. Principalmente porque la regulación bancaria va destinada a minimizar el riesgo asumido por los bancos, de forma que la probabilidad de que quiebren disminuya y no tenga que rescatarlo el Estado para evitar un daño generalizado en la economía. Normalmente, el riesgo asumido va directamente relacionado con el beneficio que se puede obtener, de forma que, a menor riesgo, menor beneficio. Por lo tanto, es habitual que la banca presione 
para eliminar las regulaciones que impiden que en tiempos de bonanza sus beneficios crezcan y en tiempos de crisis puedan llegar a quebrar. $Y$ es importante recordar que las quiebras de bancos son muy recurrentes y no algo esporádico. A lo largo de los últimos 40 años se ha vivido un proceso de desregulación en el sector financiero en general y bancario en particular que ha tenido como colofón la crisis de 2008. Se trata, obviamente, de un proceso marcado por la ideología neoliberal, que predica que el Estado no debe entrometerse en los mercados y debe dejar actuar a las empresas. Hasta que toque rescatarlas, faltaría añadir. Así, desde la década de 1980, la tendencia ha sido dejar libres los mercados financieros, lo que ha generado gran inestabilidad a nivel mundial, especialmente en países con economías más pequeñas.

En cuanto a la actuación de los principales Bancos Centrales (FED y BCE) que se han dejado guiar por esta ideología, han puesto su mirada en el control del coeficiente o ratio de capital, cuya principal misión sería la de poder absorber posibles pérdidas futuras, en lugar de vigilar de cerca la actividad bancaria, como la forma en la que se otorgan préstamos hipotecarios a promotores inmobiliarios, que es la que ocasiona estas pérdidas.

Tal y como hemos hecho en el epígrafe anterior al hablar de la política fiscal, a continuación vamos a analizar el resultado de la política monetaria y la supervisión bancaria en España.

La política monetaria la define y ejecuta el BCE. Es él quien, con el objetivo de controlar la inflación en la eurozona, que se mide mediante el índice de precios al consumo (IPC) armonizado, controla la evolución de los tipos de interés. Como venimos indicando, la política monetaria busca ser, como objetivo final, una política de estabilización económica que impida que la economía fluctúe demasiado y, por supuesto, que evite la aparición de burbujas en la economía, que son el síntoma inequívoco de ineficiencias en la asignación de recursos y son fuentes de grandes oscilaciones del PIB. Pues bien, si uno de los objetivos principales es evitar burbujas financieras, resulta obvio que la política monetaria del BCE ha fracasado, al menos en el caso de España, pues no ha impedido que se fuera hinchando a lo largo de varios años, desde la creación del euro hasta 2007 una enorme burbuja inmobiliaria con la necesaria ayuda del sistema bancario español. Cabe preguntarse cuál puede ser la causa de tal estrepitoso 
fracaso. Por un lado, los instrumentos de los que dispone el BCE tienen efecto en toda la Eurozona, todos los países que tenemos el euro como moneda, por lo que la política monetaria debe tener en cuenta la situación en todos los países, no solo en España. Por otro lado, si bien en la toma de decisiones relativas a la política monetaria influyen numerosas variables macroeconómicas, en última estancia la variable más relevante, la variable a controlar, es la inflación. La inflación, aunque se puede medir de numerosas formas, a cual más compleja, se suele medir con el IPC, lo que, como veremos más adelante, acarrea una serie de problemas bastante serios.

En cuanto a la supervisión del sistema bancario español, el responsable es el Banco de España. También en esta ocasión debemos hablar de un estrepitoso fracaso que, por cierto, se niegan a reconocer. Por ejemplo, el Banco de España no controló en absoluto los sistemas de concesión de préstamos, especialmente a promotores inmobiliarios, que fueron los que en realidad ocasionaron la quiebra de gran parte de las cajas de ahorro, y no el impago de hipotecas por parte de algunos ciudadanos, como se nos quiere hacer creer. O no controló realmente las valoraciones de las viviendas, que se hacían al alza siempre, hinchando la burbuja inmobiliaria al hacer subir los precios. Estos dos puntos son de enorme interés, pues de haberse realizado el control adecuadamente, la burbuja inmobiliaria y la crisis financiera, con sus consecuencias posteriores, hubieran sido muchísimo más pequeñas. Por no hablar de todas las actividades que han tenido lugar en el sector una vez estalló la crisis, desde la venta de preferentes, que debiera haber estado más controlada en aplicación a la normativa europea, hasta la salida de Bankia a bolsa, el banco que aglutinó a las principales cajas de ahorro que hubo que rescatar con numerosas medidas, entre ellas una inyección directa de más de 20.000 millones de euros.

En el caso de la política monetaria y de supervisión bancaria, vemos también que la actuación del Estado, esta vez no diseñada e implementada por el Gobierno (que está formado por políticos), sino por el BCE y el Banco de España que son instituciones independientes del Gobierno y se suponen apolíticas y compuestas por tecnócratas, no ha sido capaz de evitar la crisis. En algunos casos, incluso ha ayudado a empeorar la situación, como la ola de fusiones entre Cajas de Ahorro y la absorción de unos bancos por otros, auspiciada por el 
Banco de España, que ha dejado un sector financiero en España altamente concentrado, con solo unas pocas grandes entidades financieras que acaparan casi todo el mercado, es decir, un oligopolio. No hace falta insistir en que todas estas actuaciones del Banco de España responden, lógicamente, a una visión política de la economía, y no a una aplicación impoluta de la teoría económica que no dejaba otra opción. Y, como en toda actuación política, hay quienes se benefician y quienes salen perjudicados. La incapacidad de controlar la burbuja inmobiliaria, o la falta de interés en supervisar y reducir la actividad bancaria durante su creación, permitió un enorme crecimiento económico, con su correspondiente distribución (y concentración) de riqueza. Cuando el sistema financiero colapsó, ninguno de los tecnócratas entonó el mea culpa. La consecuencia de su falta de control fue obligar al Gobierno a intervenir más tarde para salvar el sistema bancario gastando cantidades ingentes de dinero aportado, en última instancia, por los contribuyentes, con las consecuencias que mencionamos en el epígrafe anterior. Otra consecuencia ha sido el aumento de poder de la gran banca en España, que se ha concentrado además en pocas manos, aumentando así el riesgo sistémico.

Si medimos el éxito de la labor realizada por el BCE y el Banco de España en términos del bienestar de la población, nos encontramos con que su actuación ha sido igual de deficiente que la actuación del Gobierno. Y tampoco en este caso su actuación se puede defender a partir de la teoría económica. Frente a la creación de una burbuja económica de grandes magnitudes a lo largo de varios años hinchada por el sistema bancario, ni se tomaron medidas de política monetaria para frenarla modificando los tipos de interés, ni se supervisó la actuación de los bancos para que limitaran la concesión de préstamos con alto nivel de riesgo y la concentración en el sector inmobiliario, lo que también hubiera limitado el crecimiento de la burbuja. 


\subsection{LA BALANZA DE PAGOS}

Tanto la política fiscal como la política monetaria tienen como finalidad encauzar, en la medida de lo posible, la situación macroeconómica del país. Es decir, tratan de influir en variables económicas que están fuera del alcance de las empresas y que, sin embargo, influyen decisivamente en éstas. Por ejemplo, un restaurante puede encontrarse como, de pronto, el número de clientes decrece sin que el motivo sea achacable al propio restaurante, simplemente por culpa de una recesión. O los compradores de vivienda ven cómo es más fácil y más barato obtener un préstamo hipotecario, sin que haya cambiado su situación personal, simplemente como consecuencia de la política monetaria y de supervisión. O el sector hotelero observa con agrado cómo llegan más turistas de EEUU que en temporadas precedentes, simplemente porque el euro se ha depreciado frente al dólar. Este último ejemplo hace referencia a la relación de una economía con el resto de las economías del mundo. Esta relación se registra en un documento contable de gran utilidad que se denomina "balanza de pagos". La gestión de la balanza de pagos es muy importante y extraordinariamente compleja, pues intervienen muchísimas variables, tanto de índole doméstico como del resto del mundo, que están íntimamente relacionadas y se influyen entre sí. En el caso de España, las posibilidades de realizar políticas para influir en los flujos de la balanza de pagos son casi nulas, pues es la UE la encargada de gestionar, a nivel europeo, los instrumentos pertinentes. Además, en un contexto de libertad de circulación de capitales y libertad de circulación de bienes y servicios, algunos de los instrumentos de control más importantes en manos de los Estados simplemente han desaparecido, consecuencia del proceso de globalización y sus presiones. Por otro lado, cuanto mayor es la apertura de una economía, mayor es el impacto que las relaciones económicas con el exterior tiene sobre su crecimiento y estabilidad económica y, por tanto, sobre la política fiscal y monetaria. Estudiar todos los pormenores de estas interrelaciones exige un curso de economía internacional, así que aquí nos limitaremos a esbozar ciertas ideas. Básicamente, las que venimos defendiendo: que la realidad es muy compleja y que nuestros modelos de predicción no son suficientemente precisos; que la teoría económica no puede emplearse para defender una opción política como la única alternativa posible; que con cualquier política económica hay 
siempre agentes económicos que se ven favorecidos y otros que se ven perjudicados. Veremos que la gestión de las relaciones de un Estado con el exterior también se puede utilizar para favorecer la concentración de poder y cómo en la definición de las políticas priman a menudo los objetivos que debieran considerarse secundarios, quedando olvidado siempre el objetivo principal: la calidad de vida de las personas.

La idea principal que debiera guiar la relación de una economía, un país, con el resto de economías o países del mundo es que esta relación debe estar equilibrada. Puede haber desequilibrios a corto plazo, claro, pero a largo plazo se deben equilibrar. Solo economías muy grandes y con ciertas ventajas, como la de EEUU o Alemania, se pueden permitir tener desequilibrios persistentes, que, por otro lado, son negativos para el conjunto de la economía mundial. Hay que pensar en la economía internacional como en un intercambio. Vamos a poner un ejemplo muy simple. Un pequeño país turístico que necesita importar petróleo estaría en situación de equilibrio si con los ingresos que obtiene de los turistas extranjeros puede comprar todo el petróleo que necesita (en realidad, lo que ocurre es que se intercambia turismo por petróleo). En la balanza de pagos, las exportaciones e importaciones de bienes y servicios se recogen en la balanza por cuenta corriente. Por simplificar, podemos decir que ahí se puede ver si un país exporta más de lo que importa o al revés. Recordemos que lo ideal es que haya un equilibrio. Por otro lado, nuestro pequeño país puede pedir dinero prestado al exterior, por ejemplo porque necesita dinero extra porque el precio del petróleo ha subido, o porque las empresas necesitan dinero para construir más hoteles y en el país no disponen de suficiente cantidad ahorrada, o porque el Gobierno se endeuda para ampliar el aeropuerto y no quiere subir los impuestos. Los flujos de dinero relacionados con la inversión se registran en la cuenta financiera de la balanza de pagos. Así, cuando un país aumenta su deuda exterior, se recoge en la cuenta financiera.

Por otro lado, el pequeño país turístico utiliza una divisa, el chavo, y el resto de países, pues cada cual la suya. Así que para realizar transacciones comerciales con el extranjero o si un extranjero quiere invertir en el país, hace falta acudir al mercado de divisas y cambiar una moneda por otra. Aquí es donde aparecen los problemas. Antes de empezar, debemos recordar que los tipos de cambio, 
históricamente, pueden ser fijos o flotantes, lo cual tiene implicaciones muy importantes. En la actualidad la mayoría de las relaciones internacionales son entre países con tipos de cambio flotantes, pero muchos países pequeños tienen su tipo de cambio anclado al USD en busca de cierta estabilidad. En la Unión Económica y Monetaria (UEM) los países tenemos el euro y su fluctuación no depende de la marcha de una economía concreta, sino de la economía europea en términos más generales. Como para negociar con el exterior hay que intercambiar las divisas, la tasa de intercambio, es decir, el tipo de cambio es un factor de enorme importancia. Así, si la divisa del país, el chavo, se deprecia, será más barato para los extranjeros venir al pequeño país turístico. Pero, por otro lado, para el pequeño país comprar petróleo será más caro. Ya tenemos un ejemplo más en el que la variación de una variable macroeconómica beneficia a unos y perjudica a otros. En términos generales, la volatilidad del tipo de cambio genera inestabilidad política, por lo que es conveniente evitar grandes fluctuaciones. Por otro lado, también hemos visto que las fluctuaciones en el tipo de cambio tienen efectos importantes y diferentes sobre el bienestar de los agentes económicos. Por todo ello, resulta necesario conocer qué variables afectan al tipo de cabio de una divisa, estando todas ellas relacionadas con la oferta y la demanda de la misma. El elevado número de variables que intervienen en los modelos económicos con economías abiertas y la interrelación entre ellas hacen que sea prácticamente imposible predecir a medio plazo el resultado de las políticas económicas en términos de cómo afectarán a la evolución del PIB o a los tipos de cambio. $Y$, como siempre, medir cómo pueden afectar al ciudadano medio es algo que ni se plantea.

En el plano comercial, si se importa más de lo que se exporta se produce una presión a la baja del tipo de cambio, al tiempo que se genera un déficit en la balanza por cuenta corriente. Se desea conseguir dinero extranjero para poder comprar bienes extranjeros, pero los extranjeros no quieren cambiar con nosotros su moneda porque no quieren comprar nuestros productos ni viajar a nuestro país. Uno de los motivos por los que ya no quieren nuestros productos podría ser que se han vuelto relativamente más caros, es decir, la inflación en nuestro país ha sido más grande que la de los otros países. Vemos cómo la inflación relativa afecta negativamente nuestra capacidad de exportar. Si las 
monedas fluctúan libremente, nuestra divisa se depreciará automáticamente debido a la falta de demanda y, al ser más barata, automáticamente todos los productos de nuestro país se habrán abaratado para los extranjeros, que volverán a comprar, aumentando así nuestras exportaciones. Para nosotros, los productos extranjeros se habrán encarecido, así que se reducirán nuestras importaciones y de esta manera se reducirá el déficit de la cuenta comercial. Sirva este ejemplo, que simplifica enormemente la realidad, para tener una intuición de cómo interactúan entre sí el tipo de cambio, el saldo de la balanza por cuenta corriente (que, recordemos, es un componente del PIB) y la inflación.

En el ámbito financiero, un Estado puede estar necesitado de fondos y, al no ser suficiente el nivel de ahorro nacional, pide prestado en los mercados internacionales. Los extranjeros estarán interesados en prestar si el tipo de interés es suficientemente elevado en relación con el riesgo de deben asumir. En este caso destacan dos tipos de riesgo: el de impago por parte del emisor de la deuda, también llamado riesgo de crédito, y el riesgo de tipo de cambio, que hace referencia a las fluctuaciones de éste. Imaginemos que una empresa hotelera de nuestro pequeño y turístico país recibe una oferta de inversores extranjeros, que desean comprar acciones de la empresa y se firma el acuerdo. Los extranjeros deberán adquirir nuestra divisa, el chavo, en los mercados financieros. El aumento de demanda hace subir la cotización del chavo. Luego, los nuevos socios deciden emitir deuda en el exterior para financiar la construcción de nuevos hoteles, lo que hace que se aprecie el chavo de nuevo. Así, las inversiones en el país y los tipos de interés también influyen en el tipo de cambio.

Imaginemos que, por el motivo que sea, el flujo de turistas disminuye, las nuevas inversiones en hoteles no son rentables y la empresa entra en dificultades financieras. Los tenedores de la deuda y los socios en el negocio hotelero quieren deshacer sus inversiones y vender sus bonos y sus acciones en los mercados financieros cuanto antes. Se ha producido primero una crisis económica en el sector turístico / inmobiliario y a partir de ahí se desencadena una crisis financiera. Esta crisis financiera también afecta al equilibrio de las cuentas del Gobierno, que ve cómo sus ingresos por impuestos disminuyen y aumentan los gastos en prestaciones sociales. Bien, toda esta situación presiona 
a la baja el tipo de cambio, pues los inversores extranjeros desean liquidar a toda prisa sus inversiones.

Sigamos con el ejemplo anterior para ver cómo el Estado, el Gobierno y el Banco Central, pueden intervenir en esta situación para enderezar la economía. Recordemos que, en este caso, todo se ha debido al desequilibrio ocasionado por malas decisiones de inversión por parte de empresas privadas, tanto locales como extranjeras. Bien, en principio, lo que está ocurriendo es una contracción de PIB, pues se está reduciendo la producción, tanto en el sector inmobiliario como en las exportaciones. Para ello, ya hemos visto que el Gobierno puede aumentar sus compras de bienes y servicios y las transferencias y el Banco Central puede bajar los tipos de interés. Pero esta opción genera déficit y deuda pública. Dado que los nacionales están sufriendo la crisis y es posible que no tengan ahorros para comprar la deuda del Estado, el Gobierno intentará que sean los inversores extranjeros los que compren sus bonos y obligaciones. Pero, en esta coyuntura económica, es posible que los inversores extranjeros, que recordemos están huyendo del país, no quieran comprar deuda. En esta tesitura, la política del Gobierno por minimizar la crisis no se podrá llevar a término. Si, además, el Gobierno se había endeudado anteriormente o el paquete para reflotar la economía es muy grande porque también lo era la burbuja o burbujas que habían generado la crisis y se requiere de mucho dinero para afrontarla, el Gobierno, y la población, tienen un problema. Necesitan dinero imperiosamente, pero no a cualquier precio. ¿Cómo conseguir el dinero y cómo gastarlo? El Banco Central podría adquirir la deuda del Estado, pero eso generaría inflación, por lo que hablar de esta posibilidad es tabú.

Normalmente, lo que puede hacer el Gobierno de un país es recurrir al FMI. Recordemos que, en ocasiones, el Gobierno que tiene que lidiar con la crisis ni siquiera es el responsable de los acontecimientos económicos precedentes. Por lo general, el FMI pedirá una serie de acciones destinadas, no a favorecer la economía, sino a beneficiar a los inversores extranjeros y, de paso a la oligarquía dominante del país en proceso de "rescate". 
Así, lo primero que se debe hacer es tranquilizar a los inversores extranjeros para que no deshagan sus inversiones en el país. ¿Cómo se hace esto? Pues evitando que la divisa se devalúe.

Esto se consigue aumentando los tipos de interés, pues se supone que esto atraerá a nuevos inversores. Pero, claro, eso podría suceder en un contexto de calma, pero no en plena crisis. Porque, además de que los elevados tipos de interés ya ponen de manifiesto un mayor riesgo que deben correr los inversores, es que el aumento de los intereses aumenta el riesgo de quiebra de las empresas endeudadas. El que nuestra empresa hotelera en apuros diga que va a pagar más intereses no significa que pueda hacerlo y eso los saben los inversores, que no son tontos. Nadie quiere invertir en una economía que está entrando en recesión donde el riesgo de crédito es muy alto. En cualquier caso, la subida de los tipos de interés, como sabemos, lastra aún más la economía, pues las empresas no invierten y los consumidores no se endeudan para financiar sus compras, por lo que el PIB disminuye, empeorando el panorama.

Como el plan de subir los tipos de interés siempre fracasa, se acaba recurriendo al plan B. Sabemos que, en definitiva, el valor de la divisa depende de la oferta y la demanda. Si los inversores extranjeros quieren vender los "chavos" y nadie se los compra, están dispuestos a venderlos a un precio cada vez menor con tal de deshacerse de ellos, por lo que la divisa se deprecia. Pero, si hay alguien que les compra los chavos, entonces el precio se mantiene constante. ¿Y quién puede asumir ese papel? Pues el Banco Central de nuestro pequeño país turístico. Sabemos que, en realidad, lo que se produce en el mercado de divisas es un intercambio, por ejemplo chavos a cambio de dólares. Así que el Banco Central debe utilizar los dólares de sus reservas (los Bancos Centrales siempre tienen reservas en divisas) y comprar los chavos que ofrecen los inversores que se van del país. De esta manera, al permanecer el tipo de cambio constante, los inversores extranjeros ven que desaparece el riesgo de tipo de cambio, se tranquilizan y dejan de deshacer sus inversiones y de vender chavos. Obviamente, esta lógica hace aguas por todas partes. En primer lugar, porque los inversores se van del país porque está en crisis, la rentabilidad de las inversiones es baja o negativa, y el riesgo de impago es muy alto. Por otro lado, los inversores que, insisto, no son tontos, saben que el tipo de cambio se mantiene gracias a la intervención del Banco Central en el mercado de divisas, 
donde está comprando los chavos con los dólares de sus reservas. Pero esas reservas no son infinitas, sino más bien muy limitadas, así que cuando se acaben, el tipo de cambio del chavo se hundirá. Por lo tanto, los extranjeros siguen deshaciendo sus posiciones. Y no solo ellos. Los oligarcas del país, las personas más ricas, también aprovechan la situación para sacar su dinero del país, aumentando así más la crisis. De esta manera minimizan el impacto de la crisis en su patrimonio. Además, y esto es muy importante, al evitarse que el chavo se deprecie, los extranjeros y los ricos consiguen muchos más dólares a cambio de sus chavos, evitando las graves pérdidas que sufrirían si realizan el cambio con un chavo depreciado.

Ante la perspectiva de que las reservas de dólares del Banco central se agoten, el FMI le hace un préstamo al país en forma de dólares que debe destinar principalmente a mantener el tipo de cambio. Lógicamente, esto no cambia nada los argumentos expuestos de por qué esto no hace sino favorecer el que los inversores extranjeros y los ricos nacionales saquen su dinero del país. Simplemente les da más tiempo. Lo que sucede es que el Estado se endeuda con el FMI para llevar a cabo una actuación que, en principio, no le beneficia en absoluto, salvo que quiera ayudar a las oligarquías del país a sacar su dinero, algo que no se puede descartar a priori. Al final, el préstamo del FMl es insuficiente, el Banco Central deja de intervenir en el mercado de divisas y el chavo se desploma. Para entonces, los inversores extranjeros y los oligarcas nacionales ya han podido deshacer la mayor parte de sus inversiones, principalmente las bursátiles, lo que también ocasiona el desplome de la bolsa nacional.

Debemos recordar que mantener un tipo de alto elevado frena las exportaciones y aumenta las importaciones, lo que genera un desequilibrio en la balanza por cuenta corriente y reduce el PIB. Así que la depreciación de la divisa en realidad supone un alivio para la economía. Además, al dejar de ser prioritario el sostener el tipo de cambio, los tipos de interés pueden reducirse, lo que también estimula el crecimiento del PIB.

Nos encontramos, pues con un país que ha recibido un préstamo del FMI que ha gastado gran parte del mismo en el mercado de divisas y del que se han beneficiado los inversores extranjeros y los oligarcas nacionales, y ahora toca devolver el préstamo más intereses. Para asegurarse la devolución de ese 
préstamo, el FMI ha exigido previamente una serie de condiciones al Gobierno del país, entre las que suelen destacar ciertas reformas en el mercado laboral y en el sistema financiero, la privatización de las empresas públicas y la eliminación del déficit, para lo cual se exige que se suban ciertos impuestos y se bajen o eliminen ciertos gastos, normalmente gastos de naturaleza social y redistributiva, como pensiones y prestaciones por desempleo. Estas medidas, además, tienen la gran ventaja de que evitan que se produzca inflación. Pero, claro, la inflación se produce acompañando el crecimiento económico. No hay inflación, simplemente, porque la economía no crece por culpa de estas medidas de corte liberal.

Efectivamente, no es defendible que las políticas propuestas por el FMI sean "neutrales”, o “apolíticas". Responden perfectamente a la ideología neoliberal, según la cual el Estado no debe intervenir en la economía (lo que justifica las privatizaciones de empresas públicas y la desregulación en la economía, especialmente en el sistema financiero y el mercado laboral, así como la reducción o eliminación de las medidas redistributivas) puesto que los mercados funcionan perfectamente y son eficientes, salvo que sea necesario salvar a las grandes fortunas y grandes empresas, en cuyo caso sí que se puede intervenir en el mercado más libre y desregulado del mundo, el de divisas, y rescatar empresas que han sido responsables de la generación de burbujas y desequilibrios macroeconómicos. En esta línea, para justificar su actuación, la retórica neoliberal del FMI se centra en la demonización sin matices del déficit público y la deuda pública (no la privada, aunque ésta ha sido la causante de las grandes crisis económicas globales) y de la inflación.

El ejemplo expuesto muestra, de forma muy simplificada, cómo la relación de un país con el exterior puede tener aspectos positivos y negativos. La casuística de esta relación es inabarcable y cada situación requiere un análisis individual. $Y$, desde el punto de vista del Estado, una política diferente. Hemos podido comprobar cómo la policía fiscal y la política monetaria también se ven afectadas $y$, a su vez, afectan a los flujos internacionales de bienes y servicios y de capitales. Las principales variables macroeconómicas, tales como los tipos de interés, la inflación, el déficit público, la inversión, el PIB... y el tipo de cambio están interrelacionadas. Cuanto mayor es el grado de apertura de una economía, 
mayor es la inestabilidad económica que se puede generar como consecuencia de las acciones de agentes económicos externos. Esto es especialmente cierto para países pequeños y medianos en términos económicos y cuyo tamaño es insignificante en comparación con los flujos de comercio y, sobre todo, de capitales a nivel mundial. No obstante, la política internacional actual está dirigida inequívocamente a eliminar las barreras a la libre circulación de bienes y servicios (aranceles, cuotas de importación etc.) y, muy especialmente a la circulación de capitales. Esta apertura que, en principio, puede generar en ocasiones situaciones ventajosas de cara a facilitar unos mercados de competencia perfecta, así como el acceso a la financiación exterior, tienen, como hemos visto, una faceta enormemente negativa, al menos para la parte de la población que sufre las consecuencias de las crisis. Esta política de derribar los obstáculos que defienden a las economías y limitar la soberanía nacional, por ejemplo, frente a burbujas especulativas, ha sido criticada por numerosos economistas, entre otros motivos, porque las negociaciones son a menudo secretas y responden al interés de las grandes multinacionales y por lo general los acuerdos escapan al escrutinio de los ciudadanos y a su aprobación por sus representantes en las instituciones democráticas. Además, la eliminación de barreras no se produce de forma global, sino selectiva, beneficiando a ciertas industrias de los grandes países, mientras que se mantienen otras barreras que benefician, de nuevo, a ciertos sectores de los países más industrializados (los que tienen más capacidad de influir en los Gobiernos de sus respectivos países). Una vez más, estamos ante una situación en la que se trata de imponer una visión ideológica de la economía muy particular pero se vende a la opinión pública como la única opción posible, la única que se ajusta a la teoría económica y, por lo tanto, apolítica.

Hemos podido comprobar de nuevo cómo las políticas económicas del Estado repercuten en la economía, en este caso influyendo en las relaciones económicas y financieras con el resto del mundo, y que estas políticas están justificadas en aras de la estabilidad económica. Hemos visto que las posibilidades de intervención estatal son variadas y que no son neutrales, en el sentido de que benefician a unos agentes económicos y perjudican a otros. Así, es posible que la actuación del Estado, en lugar de fomentar el bienestar general, 
se centre en satisfacer los intereses de la clase dominante y de los grupos de presión extranjeros. Además, con frecuencia la actuación tiene como único fin el control de ciertas variables macroeconómicas, principalmente el tipo de cambio, el tipo de interés, la inflación y el déficit público, olvidando el bienestar de los ciudadanos, que son quienes sufren las políticas de subidas de impuestos y recortes y las penurias, mientras que se produce una mayor concentración del poder económico. En este sentido, resulta paradigmático que ninguna de las condiciones que impone el FMI a los Estados a los que presta dinero haga referencia a la lucha contra la pobreza extrema y casi nunca hace referencia a la lucha contra la corrupción, por poner un ejemplo.

Finalmente recordar que, en el caso de España, nos hemos quedado sin herramientas para controlar la balanza de pagos y la inestabilidad económica que pueden generar las relaciones económicas con otros países. Dentro de la UE existe total libertad de circulación de bienes y servicios, lo que puede generar inestabilidad en la cuenta comercial. Las políticas de control comercial entre la UE y el resto del mundo se dictan en Bruselas. Dentro de la UE hay libertad de circulación de capitales, por lo que no se puede impedir que el capital europeo fluya hacia España generando burbujas financieras, que es precisamente lo que ocurrió con la burbuja inmobiliaria. La capacidad de controlar el tipo de cambio y la depreciación de la divisa nacional como medio de ganar competitividad en los mercados internacionales, se ha perdido completamente, pues es el BCE el que puede intervenir en el mercado de divisas, no el Banco de España. Además, el BCE es el que define y ejecuta la política monetaria, que influye en los tipos de interés y en la inflación. Así las cosas, en caso de producirse desequilibrios persistentes en la Balanza de Pagos, por ejemplo, con Alemania, la opción más directa que queda para nivelar la situación es que parte de la población española emigre a Alemania. Se trata de un reequilibrio natural al que estamos acostumbrados dentro de nuestras fronteras (por ejemplo, andaluces que emigran a Madrid o Barcelona en busca de trabajo) y que vemos se está produciendo actualmente, con miles de jóvenes españoles emigrando a otros países de la UE. 


\subsection{LA IMPORTANCIA DE LA DEFINICIÓN DE OBJETIVOS}

A lo largo de este capítulo hemos subrayado la importancia de ciertas variables económicas para definir los objetivos de la política económica del Estado. Por ejemplo, para monitorizar el crecimiento económico, los economistas se fijan en la evolución del PIB y, residualmente, en la tasa de desempleo. EI BCE se centra en la inflación para definir su política monetaria, teniendo un objetivo de inflación del $2 \%$ anual.

Tener estos objetivos cuantificables es de gran ayuda, pues permite medir en qué medida se están alcanzando o no. No obstante, en ningún lugar se estipula que la función principal del Estado en términos económicos sea alcanzar unos objetivos concretos en cuanto al PIB, tasa de desempleo o inflación, al menos que yo sepa. Además, estos objetivos se pueden conseguir de diversas maneras, mediante diferentes actuaciones que, como hemos visto, no afectan por igual a los distintos agentes de la economía. En esta línea de pensamiento, debemos recordar que, en el mejor de los casos, estos objetivos de la política económica son solo medios para alcanzar un fin más importante, que debiera ser, en mi opinión, mejorar la calidad de vida de los ciudadanos, tal y como se ha definido en el segundo capítulo de este libro.

En la actuación cotidiana de los Estados se puede apreciar que los objetivos en cuanto a crecimiento del PIB, reducción del desempleo y control de la inflación a cualquier precio se han convertido en fines por sí mismos. Así, se ha olvidado (o no se comparte la idea) que estos objetivos son solo útiles en la medida en que mejoran la calidad de vida de los ciudadanos y, en no pocas ocasiones, se justifican actuaciones que degradan la calidad de vida de las personas argumentando que aumentan el PIB, crean empleo o controlan la inflación.

A continuación vamos a reflexionar acerca de los problemas que se plantean cuando se utilizan el PIB, la creación de empleo y la inflación como fines en sí mismos de las políticas económicas del Estado. 


\subsubsection{EL PIB COMO OBJETIVO DE LA POLÍTICA ECONÓMICA}

EI PIB mide el valor de la producción de bienes y servicios finales de una economía. La comparación del PIB real (a precios constantes) entre dos periodos consecutivos nos permite saber si la economía crece o decrece y con qué fuerza. En principio, es de esperar que el crecimiento del PIB real influya positivamente en la calidad de vida de las personas. Efectivamente, el PIB actual en cualquier país europeo en increíblemente mayor que el de hace un siglo, lo que permite que no solo tengamos un mayor nivel de vida, sino que la población sea mucho mayor. Se produce mucho y así se pueden satisfacer mejor las necesidades de más personas. Por otro lado, un mayor número de personas permite aumentar la producción, especialmente cuando un gran número de ellas se dedica producir, a investigar y desarrollar nuevas tecnologías que aumentan la productividad.

$\mathrm{Si}$ pudiéramos decidir en qué país nacer, ¿escogeríamos ese país exclusivamente en función de su PIB o su PIB per capita? Seguro que no. Y es que el PIB presenta muchas deficiencias si se emplea como medida del nivel de desarrollo de un país, del bienestar y la calidad de vida de los ciudadanos.

Un aspecto fundamental es que no se trata exclusivamente de que la tarta sea más grande, sino de cómo se reparte esa tarta. Un país puede tener un PIB muy elevado, pero también un alto grado de desigualdad. Actualmente estamos viviendo un nuevo proceso de concentración de la riqueza a nivel mundial, con un crecimiento agudo de las desigualdades entre países y dentro de los propios países, que es dañino para la economía y para la convivencia democrática, pues supone una concentración de poder económico sin precedentes. Por lo tanto, desde el Estado democrático no parece razonable hablar del PIB sin inmediatamente después mencionar el reparto de la riqueza generada, especialmente en un contexto en el que hay personas por debajo de la pobreza absoluta viviendo en países con elevado PIB per capita. Además, hay que destacar que la hipótesis de que conforme aumenta el PIB primero aumenta la desigualdad pero después disminuye (la llamada curva de Kuznets) no se ve confirmada por la tozuda realidad. 
EI PIB, además, no mide toda la producción que se realiza en un país. Así, no tiene en cuenta la denominada "economía sumergida", ni se incluyen correctamente las actividades ilegales como el narcotráfico o la prostitución o la trata de personas (que es de por sí cuestionable que estén incluidas en un PIB que se desea maximizar). Tampoco se incluye la producción que no es objeto de transacción económica, como el autoconsumo o la economía informal. Este tipo de producción es muy importante en economías menos desarrolladas y en las más desarrolladas aumenta de manera muy significativa durante las crisis. No recoger las actividades económicas desarrolladas en el seno de la familia implica que todo el trabajo doméstico y de cuidados a familiares no se tenga en consideración. Tampoco se tiene en cuenta el voluntariado, por ser un trabajo no remunerado monetariamente. Todo ello da pie a reflexiones bastante curiosas acerca de lo que influye o no en el PIB y si un aumento del PIB realmente mejora el bienestar.

Incluir la actividad del sector público en el PIB es especialmente complejo y, obviamente, no se recogen externalidades positivas de su actuación (ni la de ningún otro agente económico), al no haber contraprestación económica.

Los recursos económicos empleados para dañar o proteger el medioambiente se valoran en el PIB, pero no se resta del PIB el valor de la contaminación generada ni, en general, el coste de las externalidades negativas, ni la desaparición de recursos naturales.

Si bien las horas de trabajo se computan en el PIB, las horas de ocio no. Sin embargo, desde el punto de vista del bienestar económico, las horas de ocio también tienen gran valor.

Todas estas omisiones y otras más en el cálculo del PIB conllevan a que no se pueda comparar el PIB de diferentes países y, sobre todo, descartan al PIB como medida del bienestar de la sociedad.

Finalmente, se debe considerar que el crecimiento continuado del PIB, que parece ser que es a lo que debe aspirar la economía según nuestros modelos actuales, tiene unos costos que no se contemplan en esos modelos pero que son gigantescos. Así, en la actualidad, el crecimiento del PIB va acompañado del agotamiento de los recursos naturales y grandes dosis de contaminación que generan problemas de enormes dimensiones que no se podrán subsanar en el 
futuro, como la destrucción de ecosistemas, la extinción de especies, y, fundamentalmente, el cambio climático, con un impacto impredecible sobre el planeta entero y la capacidad de supervivencia de cientos de millones de personas. Por lo tanto, pensar que el crecimiento constante del PIB es el objetivo que solucionará los problemas de las personas está muy alejado de la realidad, especialmente cuando esta riqueza se produce a costa de ocasionar un gran deterioro ambiental y la explotación de los recursos, tanto naturales como humanos y puede tener consecuencias verdaderamente catastróficas.

Por todo lo expuesto, parece razonable pensar que fijarse como objetivo de política económica el crecimiento del PIB, sin matizaciones, es un error muy grave que nos desvía de nuestro objetivo fundamental, el bienestar de los ciudadanos. El propio creador del PIB, Simon Kuznets, advirtió de que existen serias diferencias entre la calidad y la cantidad del crecimiento, de forma que al hablar de más crecimiento hay que especificar de qué y para qué (y yo añadiría, para quién).

\subsubsection{EL EMPLEO COMO OBJETIVO DE LA POLÍTICA ECONÓMICA}

Uno de los grandes mantras de la política económica en la actualidad es la importancia de la creación de empleo. A cualquier coste. Con la excusa de la creación de empleo se justifica cualquier acción, desde la producción de armamento, hasta la contaminación de espacios naturales protegidos, incluso la falta de medidas de seguridad e higiene en el trabajo.

Es cierto que la gran mayoría de los ciudadanos deseamos tener un empleo pero, ¿a cualquier precio? ¿Qué relación hay entre la calidad de vida de las personas y el empleo? ¿Significa siempre que tener un empleo aumenta mi calidad de vida?

En principio, un empleo, es decir, un trabajo remunerado, nos permite alcanzar un nivel de independencia económico suficiente como para cubrir, al menos, nuestras necesidades básicas. Además, es un medio para la realización personal, nos hace sentirnos útiles a la sociedad, en cierta medida da sentido a 
nuestra vida. $\mathrm{Y}$ nos permite relacionarnos con otras personas fuera del ámbito familiar.

No obstante, no todos los empleos cumplen con los requisitos necesarios para poder considerar que mejoran el nivel de vida de los trabajadores o contribuyen a su realización personal. Es más, muchos empleos son una verdadera trampa, una forma de esclavitud más o menos encubierta. Pensemos, por ejemplo, en los trabajadores de las fábricas europeas en el siglo XIX o en las fábricas del sudeste asiático en la actualidad, como casos más extremos.

No toda forma de empleo debe ser defendida como una victoria frente a la desocupación. De hecho, la idea es, desde el punto de vista de la calidad de vida, la de "trabajar para vivir", no "vivir para trabajar". Un empleo digno debe dejarnos tiempo para relacionarnos con otras personas, con la familia. Además, la retribución por el trabajo debe ser suficiente como para poder cubrir las necesidades básicas. Un empleo digno no debe poner en peligro nuestra salud física ni psíquica. Así, lo que debe fomentar el Estado, en mi opinión, es la creación de empleos dignos.

Por otro lado, para relacionarnos con otras personas y realizar actividades que fomenten nuestra realización personal no hace falta recurrir al empleo. Existen numerosos trabajos no remunerados que se pueden realizar, desde actividades diversas en el hogar hasta actividades de voluntariado. Desde el punto de vista macroeconómico, estos trabajos (son trabajos aunque no sean empleos) generan riqueza, aunque, como hemos visto, no se registran en el PIB. Tal vez eso sea un problema, pues hace que estas actividades sean totalmente invisibles en los modelos económicos. En cualquier caso, el Estado haría bien en fomentarlas.

Puede que la introducción de una renta básica permitiera a muchas personas acceder a suficiente autonomía económica como para poder dedicarse a este tipo de actividades, mejorando su calidad de vida. Por cierto, que la idea de una renta básica, contrariamente a lo que se pueda pensar, no es defendida únicamente por políticos y economistas de izquierdas. De hecho, fueron los pensadores liberales quienes retomaron la idea en el siglo XX, como Hayek. La renta tendría otros muchos efectos en el mercado de trabajo, en los que no 
vamos a entrar ahora. Para entender bien qué es la renta básica y sus implicaciones, recomiendo encarecidamente la lectura del libro de Juan Torres, "La renta básica".

Por lo expuesto, parece razonable distinguir entre "empleo" y "trabajo". Porque diferenciar estos dos términos es muy importante. Así, se dice que la política económica tiene como objetivo alcanzar el pleno empleo para maximizar la producción, cuando puede haber personas no empleadas que trabajan en el hogar o en actividades de voluntariado, produciendo lo mismo que otra persona que recibe un salario por hacer el mismo trabajo. Desde esta perspectiva, lo que se debe hacer en el caso de querer maximizar la producción es conseguir que las personas tengan un empleo o un trabajo. $Y$ los instrumentos a utilizar para alcanzar ese objetivo no tienen por qué coincidir con los objetivos para alcanzar el pleno empleo.

Debemos recordar que el mercado de trabajo es un mercado muy imperfecto, con muy poca transparencia y grandes desigualdades en la capacidad de negociación entre empresarios y desempleados. Una muestra de la falta de transparencia es que personas con una formación similar y empleo similar pueden de facto recibir salarios muy diferentes, algo que por cierto es frecuente en el caso de hombres y mujeres.

Si el objetivo de la política económica es, sin más matiz, disminuir el desempleo, lo más sencillo es eliminar todas las regulaciones del mercado de trabajo. Esto no hace que desaparezca el desempleo, pero lo deja en el mínimo posible. No obstante, esta falta de regulación genera empleo precario, inestable y mal pagado para gran parte de la población. Se produce así una redistribución de la renta, pues una parte mayor del beneficio generado por las empresas es retenida por los empresarios, quedándose los trabajadores con una parte menor de la tarta. Y esta situación genera desigualdades sociales y concentración de poder económico. De esta manera, el objetivo del pleno empleo sin paliativos no favorece en absoluto el aumento de la calidad de vida de la población. Para ver que esto es efectivamente así, basta analizar las diferencias en la desigualdad en el reparto de la riqueza y otras medidas de bienestar social de los países y el grado de regulación del mercado laboral. Además, tener a gran parte de la 
población cobrando lo mínimo indispensable para subsistir o incluso menos no solo genera inestabilidad social, sino que tiene un profundo impacto negativo en la economía, pues se reduce drásticamente el consumo interno, excepto el de los productos de primera necesidad.

No obstante, aunque las imperfecciones del mercado de trabajo hacen deseable la intervención del Estado, esta intervención debería circunscribirse a paliar los fallos del mercado, pero sin eliminar el propio mercado ni favorecer demasiado el poder negociador de una u otra parte (empresas y empleados), por ejemplo mediante la instauración de una renta básica, entre otras medidas posibles.

Si bien la reducción del desempleo es una variable que se tiene en consideración a la hora de definir la política económica, es obvio que se encuentra subordinada al PIB. De hecho, las recesiones se definen en función del PIB, no en función de la tasa de desempleo. Sin embargo, si se pone el foco en el bienestar de las personas, parece razonable pensar que a las familias les afecta más el empleo que el PIB. Así, en España hace tiempo que se salió de la recesión de 2008, pero gran parte de la población aún no se ha beneficiado del aumento del PIB, que ya sobrepasó el nivel precrisis.

Junto al PIB hay otra variable macroeconómica que tiene más predicamento e influencia en la política económica de los Estados que el empleo: la inflación. Al igual que en el caso del PIB y el empleo, la forma en la que se cuantifica y se aproxima la inflación es muy discutible. Y, de nuevo, las políticas de control de la inflación no son neutrales, afectando de forma diferente a los distintos agentes económicos, pudiendo ocasionar una gran redistribución de la riqueza de una economía.

\subsubsection{LA INFLACIÓN COMO OBJETIVO DE LA POLÍTICA ECONÓMICA}

Otro de los mantras de la ideología imperante en la actualidad, defendido a capa y espada por instituciones como el BCE o el FMI, es el control de la inflación, prácticamente a cualquier precio. Según el Artículo 105 del Tratado Fundacional de la Unión Europea, el objetivo principal del Sistema Europeo de Bancos Centrales es mantener la estabilidad de precios. Esto es, controlar la inflación. 
El control de la inflación, es decir, impedir la subida generalizada del nivel de precios, se justifica en evitar la pérdida del poder adquisitivo y la pérdida de competitividad, así como los problemas de inestabilidad económica e incertidumbre que genera. Por lo tanto, el control de la inflación parece un objetivo razonable de política económica que beneficiará la calidad de vida de las personas.

Dicho esto, es importante hacer dos matizaciones que no siempre se ponen sobre la palestra: Primero, que la inflación como tal no se mide directamente, sino que se utiliza de facto el IPC (índice de precios al consumo) como variable "proxy", lo cual genera ciertos problemas francamente graves. Y segundo, decidir la inflación que se tolera es una decisión de política económica que beneficia a unos agentes económicos y perjudica a otros.

Al igual que ocurre con el PIB, la medición de la inflación es criticable. Se trata de una tarea extraordinariamente compleja y, si bien existen diferentes formas de cuantificar la inflación y existen diferentes índices de precios, por lo general se equipara inflación a IPC. Así, los Bancos Centrales suelen centrar su política monetaria en el control del IPC, junto con el de otras variables intermedias que monitorizan la cantidad de dinero en la economía. Y lo que se fijan son objetivos de inflación medida ésta mediante el IPC.

Pero el IPC y la inflación no son sinónimos. EI IPC es el índice de precios al consumo y es precisamente eso, un índice que mide cómo evolucionan los precios de una serie de bienes y servicios de consumo, es decir, de una cesta de productos consumidos por las familias. Pero, si lo que se pretende es controlar la inflación para conservar el poder adquisitivo de las familias, fijarse en el IPC es importante, pero insuficiente. EI IPC solo se fija en ciertos bienes de consumo, no presta atención a las inversiones que realizan las familias. Así, las burbujas que se puedan generar en los precios de los activos financieros, como las acciones, o en los precios de las viviendas, no influyen en el IPC. No obstante, estas burbujas sí que afectan al poder adquisitivo de las familias, así como a la estabilidad económica y financiera.

Las consecuencias de esta miopía son terribles. Efectivamente, durante la burbuja inmobiliaria del año 2000 a 2007, el BCE no consideró que aumentara 
peligrosamente la inflación en España, puesto que el IPC se mantuvo holgadamente por debajo del $5 \%$. Por lo tanto, no consideró que hubiera que actuar. Sin embargo, desde el punto de vista del poder adquisitivo, el aumento imparable del coste de la vivienda sí que tuvo un impacto muy negativo en el nivel de vida de la familia media hipotecada. Esto es especialmente grave si se considera que fue precisamente el sector financiero el que canalizó el flujo de dinero desde otros países de la UEM hacia España, generando la burbuja inmobiliaria. Tanto el BCE, con la política monetaria, como el Banco de España, ejerciendo su función supervisora, hubieran podido frenar la burbuja. No obstante, esta mayor cantidad de dinero que fluía a nuestra economía, como se destinaba al sector inmobiliario y no a la compra de bienes en la cesta del IPC, no hizo que éste subiera, por lo que no se dispararon las alarmas, a pesar de que el poder adquisitivo de muchas familias se hundió por mucho tiempo.

Por otro lado, las motivaciones que guían el control de la inflación en unos niveles u otros, así como los instrumentos de política económica escogidos, tampoco son neutrales desde el punto de vista ideológico. Las fluctuaciones no anticipadas de la inflación redistribuyen la riqueza entre prestamistas y prestatarios y el ingreso entre empleados y empresas, en ambos sentidos. Unos ganan y otros pierden. Así, por ejemplo, un país endeudado (si ha emitido la deuda en su propia divisa, no en dólares, por ejemplo), puede devolver la deuda fácilmente si sufre inflación. Obviamente, esta solución no agradará a los acreedores internacionales, que cobrarán en una divida devaluada a causa de la inflación. Es posible que sea por esto que el FMI insista en mantener la inflación en niveles muy bajos, aún a costa de crear o magnificar recesiones económicas, desempleo y pobreza. Se trata de una decisión política, en la que priman los intereses de unos agentes económicos sobre otros. Este hecho no es ni bueno ni malo, pero hay que ser honestos e informar claramente de quienes se verán beneficiados y quienes perjudicados por las decisiones que se adopten. 



\section{REDISTRIBUCIÓN DE LA RENTA}

Cualquier área de intervención estatal en la economía implica un proceso de redistribución. La creación de mercados de competencia perfecta y la lucha contra los monopolios, la gestión de los bienes públicos, la política industrial, el tratamiento de las externalidades, las actuaciones en política fiscal y monetaria... todas, insisto, todas las actuaciones del Estado tienen efectos en la redistribución de la renta. Además, el Estado puede intervenir directamente con políticas puramente redistributivas, como pueden ser las prestaciones por desempleo $o$ las pensiones públicas por jubilación.

La redistribución de la renta es la pieza clave para entender las diferentes opciones políticas en cuanto al papel del Estado en la economía. Es decir, para diferenciar entre las diferentes corrientes políticas y académicas, lo más sencillo es fijarse en cuál es su postura en cuanto a la política de redistribución. Porque, en función de cómo sea el grado de redistribución deseado y cómo lo pretendan alcanzar se fijarán el resto de políticas. Así, y simplificando un poco, la verdadera discusión política gira en torno a la distribución de la renta y, al estar ésta relacionada con todas las demás políticas económicas estatales, pues también les afecta. Es decir, una corriente de pensamiento económico y político que sea contraria a la redistribución, también apoyará de facto políticas que favorezcan el laissez faire, minimizando por tanto el papel regulador del Estado, por ejemplo en lo relativo a la lucha contra la contaminación, negará la necesidad de la participación del Estado en el ámbito de la educación y la sanidad y se opondrá al empleo de la política fiscal, por considerarla contraproducente (y por justificar la existencia de impuestos), y preferirán la política monetaria como medio de alcanzar la estabilidad macroeconómica. Esto es así porque todas estas actuaciones del Estado implican redistribuir la riqueza generada por la economía, de forma más o menos directa. Es de forma indirecta, cuando se le ordena a una empresa contaminante que modifique su sistema productivo, se le obliga a disminuir beneficios al menos a corto plazo. $Y$ ocurre de forma directa, cuando el Estado recauda impuestos para sufragar la política educativa, sanitaria o 
implementar políticas de estabilización macroeconómica. Sensu contrario, las corrientes políticas que son favorables a la redistribución de la renta y la riqueza sí que apoyarán estas actuaciones.

En muchos casos la actuación del Estado en la economía es el resultado de una lucha en la que se decide quién aporta dinero al Estado y quién recibe dinero del Estado. Actualmente, los dos bandos de esta lucha son, de una parte, los grandes capitalistas y multimillonarios y, de otra parte, el resto de ciudadanos, que son la gran mayoría. Es decir, de un lado están los que más tienen y más ingresan, que son los que, con un sistema tributario progresivo como el que propugna la Constitución Española, deberían aportar más a las arcas públicas y recibir menos y, además, tienen el poder de influir en las decisiones políticas, y de otro lado están el resto de ciudadanos. Es muy probable que el lector no perciba la situación en estos términos, pero lo cierto es que existe un enorme grado de concentración de poder económico que presiona a los Estados, incluida España, para que, por ejemplo, se reduzcan los impuestos que afectan a las grandes empresas y a los grandes propietarios, se permitan la existencia de paraísos fiscales y, además, el Estado subvencione las actividades económicas de las grandes empresas e incluso su rescate con los impuestos sufragados por los ciudadanos, entre otras e innumerables actuaciones. Este tipo de redistribución es perfectamente defendible. Se trata simplemente de una opción, con sus argumentos y razones. Pero es fundamental resaltar que no se trata de una opción "científica" incontestable que se basa en una teoría económica que es una verdad inmutable. $Y$ también es importante tener claro qué consecuencias tiene esta opción para el conjunto de la sociedad y qué intereses está defendiendo, que no son otros que los de aquellos que defienden el mantenimiento del statu quo y la concentración de poder. Como estamos viendo a lo largo de este libro, esta opción es muy ineficiente desde el punto de vista económico, al contrario de lo que se nos quiere hacer creer.

Dado que en este ensayo defendemos que la excesiva concentración de poder económico es un grave problema para el funcionamiento eficiente de la economía, la supervivencia de la democracia y las sociedades libres, así como un factor determinante en el cambio climático, la distribución y la redistribución de la riqueza que se va a proponer no es la que va de pobres a ricos, sino la que va de ricos a pobres. Por lo general, siempre que se habla de distribución y 
redistribución de la riqueza pensamos que el dinero va de los ricos a los pobres. No obstante, esto no es necesariamente así. Históricamente ha sido más bien al revés. De hecho, en las últimas décadas, a pesar de la sensación intuitiva que podamos tener, se está produciendo un proceso tremendo de concentración de la riqueza en unas pocas manos y los Estados son cómplices necesarios de esta evolución. Una vez más las decisiones que toman los Estados y que favorecen esta concentración de poder se apoyan en una descripción de la economía que se vende como la única posible, la única técnica y apolítica, lo cual es falso. En esas teorías se olvidan de enunciar cuál es el fin último que se persigue, que en realidad es mantener el statu quo.

Llegados a este punto, conviene recordar una vez más que cuando estamos hablando de los "ricos", nos referimos a los que ostentan el poder económico y tienen capacidad de influir directamente en las decisiones políticas. Por lo tanto, un empresario o un empleado que gana 100.000 euros anuales brutos para mantener a una familia dista mucho de ser "rico" en los términos de este ensayo, aunque tenga tres coches y dos chalets. En este sentido, es curioso comprobar que personas con ingresos muy exiguos se perciben a sí mismas como "ricas" y, por lo tanto, apoyan las medidas fiscales, laborales y redistributivas propuestas por éstos que, en realidad, les son perjudiciales. El caso de los impuestos a las grandes fortunas o a la tasa Tobin resulta paradigmático. Uno de los factores que puede haber ayudado a esa percepción por parte de la clase trabajadora es el sutil proceso de manipulación mediante la modificación de los conceptos empleados en economía y en los medios de comunicación, que han introducido los vagos conceptos de "clase media", "clase baja" y "clase alta", desdibujando el significado del concepto de "clase trabajadora", que es la que obtiene sus ingresos principales trabajando, y el de "clase capitalista", que es la que obtiene sus ingresos de la rentabilidad de sus inversiones.

A continuación vamos a ver qué entendemos por distribución y redistribución. Después comentaremos cómo argumentan aquellos que se oponen a las medidas distributivas y redistributivas del Estado. Seguidamente explicaré por qué, desde mi punto de vista, es fundamental que exista un correcto reparto de la riqueza que garantice las condiciones necesarias para que las personas podamos desarrollar todo nuestro potencial en sociedades sanas y ser felices. 
Y, para finalizar este capítulo, repasaremos cómo el Estado puede llevar a cabo la distribución y redistribución de la renta (lo que se ingresa) y la riqueza (lo que se posee), desde la perspectiva de los ingresos y de los gastos.

\subsection{DISTRIBUCIÓN Y REDISTRIBUCIÓN}

Actualmente se define la economía como la ciencia que trata la asignación eficiente de los recursos escasos. Se trata, en opinión de muchas economistas, de una definición bastante vaga. Asignar, ¿con qué objetivo? Ese objetivo, que implica una ética subyacente, unos valores, una visión del mundo, es en realidad la clave a la hora de decidir cómo asignar los recursos escasos. Precisamente ésta es una de las razones por las que la economía no es una ciencia con verdades absolutas, como las matemáticas o la física. En cualquier caso, la definición actual ha puesto el foco en los "recursos escasos". Así, el objetivo principal de la economía es aumentar la producción, que crezca el PIB, para lo que hay que gestionar eficientemente los recursos escasos de los que se dispone. El que la economía crezca, ya lo hemos comentado anteriormente, puede ser un buen objetivo en determinadas circunstancias, pero no siempre ni a cualquier precio ni eternamente. $Y$ depende de cómo se cuantifique ese crecimiento. Por otro lado, en esta visión simplista de la economía se trata solo del crecimiento de la "tarta", y no de cómo se reparte, que es un factor económico de primera magnitud y afecta directamente a la calidad de vida de las personas. Lógicamente, cuanto mayor sea la tarta, más hay para repartir, pero el hecho de que la tarta sea más grande no excluye la posibilidad de que una sola persona se coma toda la tarta ella sola. Es cierto que hay economistas que defienden la llamada curva de Kuznets, según la cual el crecimiento del PIB genera al principio un aumento de la desigualdad pero luego, al seguir creciendo el PIB, la desigualdad va disminuyendo. No obstante, está constatado que esta hermosa teoría, como tantas otras teorías económicas, no se cumple en la realidad.

Siguiendo con el ejemplo de la tarta, las personas, a lo largo de la historia, han ido desarrollando métodos de producción que han permitido aumentar las cantidades producidas, aumentando así la tarta. El avance ha sido espectacular 
especialmente en los últimos dos siglos, en los que se han dado unas circunstancias especiales en cuanto a libertad personal y libertad de empresa que han estimulado el desarrollo tecnológico. Así, decimos, las personas, en colaboración, han aumentado la tarta. Pero, si bien antiguamente todas aportaban principalmente su trabajo, desde la revolución industrial unas aportan su tiempo, esfuerzo físico, conocimientos y talento, su trabajo, mientras que otras aportan su dinero, con el que compran las máquinas necesarias para el proceso productivo, el capital. Surgen así, en el sistema capitalista, dos clases sociales que colaboran en el proceso productivo y que son necesarias, la clase trabajadora y la capitalista, que son las que se deben repartir la tarta. Obviamente, las diferencias entre ambas clases son enormes. Por ejemplo, el trabajador debe acudir a su puesto de trabajo diariamente, mientras que el inversor capitalista cobrará su parte sin tener que dedicar tiempo a controlar la inversión, pues puede incluso contratar a alguien para que realice estas tareas, si lo estima necesario. Pero, en cualquier caso, en el sistema capitalista actual (que no es el único posible), tanto trabajadores como capitalista son necesarios. La cuestión es, de la tarta que producen, ¿cómo se reparten las porciones? ¿Qué parte le corresponde a los trabajadores (operarios, empleados, directivos), que aportan su tiempo y esfuerzo y conocimientos diariamente, y qué parte al capitalista que financió la creación de la empresa, tal vez hace muchos años, o incluso ha heredado las acciones de la empresa? Los repartos siempre ponen de manifiesto las relaciones de poder. Así, si el poder de los capitalistas es mayor, ellos se llevarán una porción más grande. Si el poder de los trabajadores es mayor, serán ellos los más beneficiados. $Y$ hay que ser consciente de que el reparto puede ser muy, pero que muy desigual. En ocasiones, cuando hay un reparto es conveniente llamar a una tercera persona para que ejerza de árbitro, y ahí es donde entra el Estado. Así, el Estado puede articular diferentes formas de influir en el reparto de la tarta. Lógicamente, esas formas de influir en el reparto serán atacadas por aquellos que vean disminuir la parte de la tarta que ellos consideran que les toca. Históricamente, la parte débil siempre ha sido y es la de los trabajadores. El mercado laboral es un mercado muy imperfecto y, además, las personas necesitan trabajar para vivir (al menos en la economía capitalista actual), salvo que se sea capitalista, por lo que su posición negociadora es mucho más débil. ¿Cómo puede el Estado mediar en la 
distribución de la tarta entre trabajadores y capitalistas para proteger los intereses de los trabajadores? Regulando aspectos como el derecho a la huelga y a la negociación colectiva, legalizando los sindicatos de trabajadores, fijando un salario mínimo, creando un seguro de desempleo, legislando en materia de contratación y despido y, en general, regulando el mercado laboral y las condiciones de trabajo (jornada laboral, días de descanso y vacaciones, seguridad e higiene en el trabajo). Y mediante una verdadera renta básica vital universal. En este contexto, es fácil comprender que haya personas que defienden a capa y espada la "liberalización" y "flexibilización" del mercado laboral, pues de esta manera defienden los intereses de la clase capitalista, frente a los que defienden una mayor protección a los trabajadores. Este es un ejemplo muy claro de que, en ocasiones, la "no regulación" implica de facto una posición política muy clara y no precisamente en pro de la libertad de las personas. En última instancia se trata de la lucha por el reparto de la tarta.

Y bien, ¿cómo se ha repartido la tarta en las últimas décadas? ¿quién se lleva más, el capitalista o los trabajadores? Hagan sus apuestas. Lo que resulta interesante es ver cómo el porcentaje de reparto ha fluctuado mucho desde la segunda guerra mundial y cómo varía entre países. Estos datos son además importantes en muchos debates económicos, como por ejemplo cuando se discute que favorecer a los trabajadores regulando el mercado laboral afecta negativamente al crecimiento del PIB. A este respecto, hay que tener en cuenta que el consumo privado, el de los trabajadores, es una de las variables que afecta al PIB, así que, si los trabajadores no pueden gastar el PIB se resentirá, salvo que recurran a endeudarse, lo cual también tiene sus efectos económicos negativos (y positivos para los bancos).

Lo que hemos comentado hasta ahora es lo que he llamado "distribución". Se hace la tarta y se distribuye entre los capitalistas y los trabajadores. En el proceso de "redistribución", tanto capitalistas como trabajadores deben aportar a las arcas del Estado conforme al sistema tributario establecido y luego el Estado reparte el dinero recaudado, generando unos ingresos a las personas o empresas beneficiarias (pensiones, desempleo, subvenciones), o gastando en políticas que reducen sus gastos (educación, sanidad, vivienda). Otra forma indirecta de redistribuir la riqueza es mediante la realización de inversiones en 
infraestructuras o de política industrial, que tienen un impacto geográfico concreto, o el propio gasto en empleados públicos. De hecho, hay países en los que el Estado es el "empleador de último recurso" y contrata a las personas desempleadas de larga duración durante unos meses al año para realizar tareas comunitarias.

Al igual que en el caso de la distribución, también la forma en la que se haga la redistribución es el resultado de una lucha de intereses, que en este caso consta de dos fases. En la primera se determina quién aporta y cuánto al Estado. En la segunda se establece quién se beneficia de la acción estatal. En este contexto, podemos entender que la confrontación dialéctica gire en torno a dos ejes: los problemas que generan los impuestos para la asignación eficiente de los recursos escasos y el mal uso que el Estado hace del dinero recaudado. Obviamente, los sistemas tributarios distan mucho de ser perfectos y el Estado también actúa ineficientemente en muchos casos, despilfarrando y dejándose corromper. Las causas de estas ineficiencias las analizaremos más adelante. En este momento estamos tratando cuáles son las motivaciones económicas que justifican la actuación del Estado dados unos objetivos concretos. Pero veamos primero, algunos argumentos que se emplean en contra de la actuación redistributiva del Estado.

\subsection{ARGUMENTOS CONTRA LA ACTUACIÓN REDISTRIBUTIVA DEL ESTADO}

Hemos visto que, en el caso de la distribución, existen voces que defienden la inacción del Estado, pues, por lo general, en la actualidad, su actuación va dirigida a aumentar la parte de la tarta que va a los trabajadores. Esto no siempre ha sido así, y a lo largo de la historia vemos ejemplos de cómo el Estado prohíbe las organizaciones sindicales, la huelga y castiga duramente las manifestaciones reivindicativas de los trabajadores. O simplemente no regula el mercado laboral, dejando a los trabajadores desprotegidos. 
Pasemos al tema de la redistribución. Empecemos por el pago de impuestos. Si bien ni a los trabajadores ni a los capitalistas nos gusta pagar impuestos, actualmente son solo los grandes capitalistas y las personas más acaudaladas las que tienen la posibilidad real de influir en las decisiones políticas y modelar a su gusto el sistema tributario. Dado que disminuir el importe de gasto es muy complejo y tanto trabajadores como capitalistas están en contra de que se les reduzcan los ingresos y beneficios que les llegan del Estado, el hecho de que un grupo (el de los capitalistas) consiga pagar menos impuestos necesariamente implica que el otro grupo (el de los trabajadores) tendrá que pagar más o el Estado se tendrá que endeudar. De esta manera, en numerosos países la evolución del sistema impositivo ha reducido de facto el importe recaudado de las grandes empresas multinacionales y de las grandes fortunas, que cuentan con numerosos mecanismos para evadir al fisco, de forma legal o ilegal, amnistías fiscales y paraísos fiscales, mientras que la carga tributaria que recae sobre los sueldos de los trabajadores es cada vez mayor y son éstos los que realmente sostienen el sistema. Ese sistema que luego rescata a los bancos y a las grandes multinacionales para proteger el "bien común".

Junto a los impuestos, pero dentro del ámbito del gasto, el movimiento neoliberal, que es el que defiende a los capitalistas y a las grandes fortunas y, por lo tanto, el mantenimiento del statu quo y la concentración del poder económico, critica duramente que el Estado ayude económicamente a los desempleados y a los más desfavorecidos.

Dado que se trata de dos temas de gran importancia y que aparecen de manera recurrente en las discusiones económicas, es interesante hacer algunas apreciaciones sobre algunos supuestos que subyacen a la argumentación neoliberal en contra de ciertos impuestos y de ciertas ayudas sociales y, por tanto, contra el papel del Estado en la redistribución de la renta y la riqueza. Estos supuestos de partida son la meritocracia y la criminalización de la pobreza.

\subsubsection{LA MERITOCRACIA}

En una meritocracia, el poder es ejercido por aquellas personas que son más válidas, las que están más capacitadas. Desde esta perspectiva, en numerosísimas ocasiones se argumenta que las personas que han alcanzado 
una posición de poder económico son las más capacitadas, las que más se han esforzado, las que más han arriesgado y, por lo tanto, las que más se merecen estar en esa posición, que han logrado alcanzar gracias a sus méritos, sus cualidades, su trabajo duro y perseverancia. En este contexto, no parece justo que estas personas, que no solo son las más capacitadas intelectualmente, sino que también son las más trabajadoras, sean las que más tengan que aportar para sufragar el gasto público. A fin de cuentas, su trabajo duro es el que genera empleo y de ese empleo se cobran también impuestos. Además, si se les obliga a pagar impuestos más elevados de lo que ellas consideren justo, estas personas tan valiosas para la economía se irán a otro país causando un daño irreparable al país que abandonen. Para terminar, se suele mencionar el caso de un emprendedor hecho a sí mismo, como prueba irrefutable de que ésta es la situación habitual.

Por desgracia, la situación expuesta en el párrafo anterior dista mucho de la realidad. Si nos fijamos en los multimillonarios, en las familias que controlan el dinero, los medios de comunicación y la política, nos encontramos con una realidad muy diferente. No son personas que han alcanzado la cima y el poder desde la nada, solo gracias a sus extraordinarias capacidades y capacidad de abnegación. Más bien son herederas de estirpes de rancio abolengo. Su fortuna proviene de sus antepasados y los orígenes no siempre son inmaculados, pues están relacionados con actividades delictivas o la explotación de otros seres humanos. Por ejemplo, en España, algunos de los más ricos pertenecen a familias nobiliarias que llevan ligadas al poder real durante siglos. Otros deben su riqueza a sus relaciones directas con la dictadura franquista, de la que fueron personajes importantes. Otras posiciones de poder surgen por contactos políticos y actividades corruptas más recientes. Coja el lector la lista de Forbes de los más ricos de España e investigue, si quiere. En todos los países del mundo, incluso en los EEUU, la movilidad de clase, la posibilidad de mejorar en la escala social, es mucho más limitada de lo que pueda parecer a simple vista. $Y$ las personas que entran en el club de los más influyentes se cuentan con los dedos de la mano y nunca parten de cero. Por mucho que nos hablen de sus méritos y sus garajes.

Por otro lado, aun concediendo que en algunos pocos casos se pueda dar la circunstancia de que se ha logrado alcanzar un elevado nivel de ingresos y 
poseer un extenso patrimonio gracias al trabajo y al esfuerzo personal, esto no justifica per se que estas personas no deban pagar impuestos elevados, y mucho menos escaquearse de pagar. Si la renta y el patrimonio se deben asignar en función del esfuerzo realizado y las horas de duro trabajo, entonces los empleos mejor retribuidos deberían ser los de algunos jornaleros, que trabajan 14 horas bajo el sol sin parar. Vemos, pues, que el mero esfuerzo no es una variable que sirva para determinar la riqueza de las personas. Tampoco la inteligencia, pues es obvio que las personas más ricas del mundo no tienen por qué ser las más inteligentes. $\mathrm{Ni}$, obviamente, la honradez, pues constantemente se publican noticias que muestran el comportamiento indecente de las personas más adineradas. Tampoco influye su capacidad de hacer ganar dinero a las empresas para las que trabajan, pues son de sobra conocidos los bonus que se reparten los altos directivos cuya mayor gesta ha sido hundir la empresa para la que trabajaban, llevándola a la quiebra. Ni el esfuerzo, ni la inteligencia, ni la honradez, ni la capacidad de generar beneficios son factores determinantes que expliquen el nivel de ingresos. Por lo que decir que los más ricos lo son porque son los más esforzados, inteligentes, honrados y generadores de beneficio es absolutamente falso. Lo importante es la situación de partida, el patrimonio inicial y los contactos. Y el contexto económico y social. Puede que Alfredo Di Stéfano fuera tan buen jugador de fútbol como lo es Leo Messi, pero sus ingresos no son en absoluto comparables. $\mathrm{Y}$ la suerte. $\mathrm{Y}$ no todas las personas salimos de la misma posición de partida (ni tenemos la misma suerte). Pequeñas desigualdades marcan grandes diferencias con el paso del tiempo. Por ejemplo, la capacidad de emprender negocios no es la misma si tengo dinero de sobra para invertir que si tengo que acudir a un banco a obtener financiación. Mi seguridad económica no es la misma si tengo unos ingresos asegurados porque tengo propiedades alquiladas. Si quiero montar un grupo de rock y mi padre es el propietario de varios locales de ocio nocturno, lógicamente lo tendré más fácil. No es lo mismo si vivo en un piso que me regalan mis padres que si debo pagar un alquiler mensual. $\mathrm{Y}$ así se puede seguir ad eternum. Con esto no estoy negando el esfuerzo de estas personas, sino que pongo de manifiesto que la situación de partida es extremadamente importante y eso no depende de uno mismo. 
Por otro lado, es de destacar que muchas de las personas más adineradas y poderosas del mundo le deben su posición al propio Estado. No solamente los que han medrado a la sombra de reyes y dictadores. También los propietarios de grandes empresas que han disfrutado de monopolios, concesiones públicas, contratos muy lucrativos con el Estado, financiación pública en condiciones muy ventajosas etc. O los que, especialmente en algunos sectores como el financiero, se han beneficiado del proceso de desregulación iniciado en los años 80 . Esto es muy importante resaltarlo, porque el poder que tienen actualmente las grandes corporaciones financieras era absolutamente inimaginable en los años 70 , con unas entidades financieras de tamaño minúsculo. Su evolución se la deben al Estado, que reguló a su favor. Lo mismo se puede decir de otras industrias que maman profusamente de la teta del Estado, en la salud y en la enfermedad.

En este contexto, hablar de meritocracia parece totalmente fuera de lugar. $Y$ no querer pagar impuestos, una falta de escrúpulos. Por lo tanto, la amenaza de que estas personas se vayan a vivir al extranjero tampoco parece que deba tomarse muy en serio, por el poco daño que haría a la economía en tanto a pérdida de talento. Más bien sería beneficioso si de esta manera se limita la concentración de poder, el traspaso de recursos públicos a manos privadas y se acaba con las posiciones dominantes de las empresas que, amparadas por el Estado, cercenan la competencia.

\subsubsection{LA CRIMINALIZACIÓN DE LA POBREZA}

El reverso tenebroso de la historia de la meritocracia es la criminalización de la pobreza. Implica que el que es pobre o carece de suficientes recursos, el que tiene un empleo mal retribuido o es maltratado en su puesto de trabajo, es el culpable de su suerte. Es decir, se merece lo que tiene, pues seguro que se debe a que es un vago, holgazán, incapaz de esfuerzo ni autodisciplina. No se ha dedicado a formarse o tiene una gran aversión al riesgo, por lo que se conforma con el primer empleo que encuentra. El sueño de todas estas personas, una gran mayoría de las sociedades avanzadas, por otra parte, es tener una "paguita" y no pegar un palo al agua, viviendo a costa del esforzado trabajo de los demás. Por otro lado, lo habitual será que malgasten esa "paguita" en vicios, como 
celebrando botellones en la calle el día de cobro, mientras destrozan el mobiliario urbano.

Este razonamiento subyace a la idea de que el seguro por desempleo solo sirve para desincentivar la búsqueda de un nuevo trabajo y, por extensión, para negar la validez de numerosas medidas de regulación laboral y de asistencia social. Se asegura que muchos trabajadores son haraganes y que se aprovechan de la bondad del empresario que los contrata. Que las ayudas sociales solo sirven para crear una población mantenida y sumisa, vaga y sin aspiraciones en la vida. $Y$ que estas ayudas inciden negativamente en el mercado laboral, pues se pierde mano de obra disponible, si bien de baja calidad.

La percepción que tiene del ser humano alguien que realiza estas afirmaciones es bastante triste. De todo hay en la viña del Señor, pero no creo, francamente, que ésta sea la situación generalizada. Y si lo es, la causa no estará en la ayuda económica, sino que será previa a ella y se tendrá que paliar. Yo creo que las personas quieren trabajar. $Y$ no deja de ser curioso que se critiquen las ayudas a los pobres "que no quieren trabajar" pero que no se critique con la misma intensidad a los ricos que se pueden encontrar exactamente en la misma situación, cobrando del dinero público de ayudas estatales cantidades infinitamente más grandes. Máxime cuando luego ves a esos mismos pobres trabajando en condiciones muy duras y salarios ridículos, si se les ofrece la oportunidad. Lo que ocurre es que estas ayudas dan cierto margen de maniobra a las personas, de forma que no tienen que verse obligadas a realizar determinadas actividades en régimen de semiesclavitud que, al no ser ocupadas por trabajadores nacionales, son realizadas por inmigrantes ilegales que carecen de cualquier tipo de protección. Se trata, por tanto, de negar toda protección al trabajador para que tenga que aceptar sin rechistar las condiciones laborales ofrecidas por empresarios sin escrúpulos.

Encontrarse sin ingresos, abocado a la ayuda o caridad externa, sin poder encender la estufa en invierno o temiendo ser desahuciado, es una situación muy triste y desesperada. No debiera ser motivo de escarnio. Desde el punto de vista de este libro, el Estado debe realizar lo que sea necesario para garantizar un mínimo que permita a las personas vivir con dignidad. No es una cuestión de caridad, sino de justicia social, un derecho de los ciudadanos. Ciertamente, no es razonable culpar a las personas, muchos con hijos, que se encuentran es esta 
situación en la que nadie quiere estar. Para juzgar a estas personas, cada cual con su casuística, hay que conocer de primera mano sus vivencias. Las causas que las han llevado a esa situación, que pueden ser múltiples. Esto es especialmente importante en el contexto social en el que vivimos actualmente en España, en el que ni siquiera tener estudios universitarios y un trabajo garantizan superar el límite de la pobreza.

\subsection{POR QUÉ ES NECESARIO REPARTIR LA RIQUEZA}

Hasta ahora hemos comentado que el de la distribución y redistribución de la riqueza es un tema escabroso, pues consiste en quitar a unos para dar a otros. Por eso parece que decidir acerca de cómo realizar la asignación de las rentas no puede dejar de ser un problema cuya solución necesariamente será subjetiva. Ciertamente, cada una de las partes en conflicto siempre querrá más y la solución dependerá de cuál de ellas tenga más poder de negociación o presión. No obstante, sí que se puede argumentar que es necesario repartir la riqueza. Y que el reparto debe ser inspirado por el principio de progresividad. De hecho, una de las funciones del Estado en la economía debe ser realizar este reparto de forma adecuada. Obviamente, repartir implica que unas personas saldrán perdiendo a corto plazo, pues se les detraen recursos. Pero, como veremos, a medio plazo es toda la sociedad la que sale ganando, también los que más aportaron. $\mathrm{Y}$ no repartir es enormemente ineficiente desde el punto de vista económico.

Recordemos el ejercicio mental de imaginar en qué país nos gustaría nacer en una vida futura. Podemos elegir el país, pero no la familia ni el sexo. ¿En qué país nos gustaría vivir? Probablemente se trata de un país democrático que tenga un gasto público elevado, con alto nivel de redistribución de la renta, y también unos impuestos elevados, pues todos estos factores están interrelacionados: Sin impuestos elevados no hay ingresos públicos elevados y sin éstos no es posible realizar una verdadera política redistributiva. Además, en el país elegido los salarios también serán elevados. Probablemente no hayamos escogido ningún paraíso fiscal. El hecho de no pagar impuestos no garantiza en 
ningún caso mejor calidad de vida. De hecho, curiosamente, algunos paraísos fiscales reciben ayudas para el desarrollo de la Unión Europea. Si hemos elegido un paraíso fiscal, lo más seguro es que sea uno en el que haya pocas desigualdades económicas entre sus habitantes. Vemos, pues, que las sociedades que percibimos como las que disfrutan de mejor calidad de vida son sociedades bastante igualitarias, sin grandes desigualdades, y donde incluso los más pobres pueden satisfacer sus necesidades básicas.

¿Y si pudiéramos elegir cuándo y dónde nacer? Es decir, no solo el lugar, sino el momento de la historia. ¿Elegimos el imperio egipcio, el asirio, el chino? ¿Grecia, Roma? ¿El imperio Inca? ¿El imperio español, el francés, el británico? ¿O preferimos el momento actual? Si no sabemos en qué familia vamos a nacer ni nuestro sexo, e incluso si pudiéramos elegir ser faraón o emperador, probablemente prefiramos el momento actual o uno cercano. $Y$ es que la mejora en la calidad de vida en las sociedades occidentales más avanzadas ha sido enorme desde la revolución industrial. ¿A qué se ha debido esta evolución? Siguiendo a Ortega y Gasset, han concurrido dos factores: democracia y técnica. Y estos factores, añado yo, están relacionados, van de la mano. Efectivamente, la democracia implica un reparto de poder que incentiva el libre pensamiento y la actividad económica y éstas, a su vez, impulsan el avance científico y tecnológico. En las sociedades feudales e imperiales el poder estaba muy concentrado. Una pequeña parte de la población ostentaba toda la riqueza económica, mientras el resto sobrevivía malamente. Los ricos no tenían ningún incentivo en realizar cambios de ningún tipo en la estructura económica ni social por temor a perder su posición y modificar el statu quo. Y, en la España de Felipe II, en cuyo imperio no se ponía el sol, el trabajo estaba mal visto, como recordará cualquiera que haya leído Lazarillo de Tormes a tenor de sus aventuras con el hidalgo. Tan solo en los pequeños Estados, como en las repúblicas italianas o en los Países bajos, donde no había tal concentración de poder, se dieron avances tecnológicos relevantes. Había competencia mercantil y esa competencia espoleaba la inventiva, en un contexto de libertad de pensamiento y libertad económica. Por lo tanto, vemos que la concentración de poder político y económico, junto a las formas económicas que le acompañan, como la esclavitud o el feudalismo, son contrarias al crecimiento económico. Desde Montesquieu solemos aceptar la idea de que la separación del poder político en 
poder ejecutivo, legislativo y judicial es beneficioso para el funcionamiento de nuestras sociedades y redunda en una mayor calidad de vida. No obstante, olvidamos que el poder económico, si continúa concentrado, puede corromper los otros tres poderes. Por lo tanto, una sociedad sana debe impedir a toda costa la concentración del poder económico.

El reparto de la riqueza que tuvo lugar paulatinamente a lo largo de los siglos siguientes en algunos lugares permitió aumentar el consumo de parte de la población que hasta el momento no podía participar apenas en la economía. Apareció la burguesía y había más posibilidades de mejorar en la escala social. Esto hizo que aumentasen los recursos económicos y también los ingresos del Estado. Al aumentar el consumo, las clases adineradas que actuaron como empresarios también se vieron favorecidas. Un mercado de mayor tamaño y más libre fomenta la innovación tecnológica, formas más eficientes de producir, la creación de nuevos productos.

Como sabe el lector, la historia es muchísimo más compleja de lo que acabo de esbozar en el párrafo anterior, pero sirva para subrayar que en pocos siglos se ha pasado de unas estructuras políticas y económicas donde el poder estaba muy concentrado a otras estructuras más democráticas, con menor concentración de poder económico y que esta evolución ha ido aparejada de un aumento en la calidad de vida de las personas sin precedentes. La calidad de vida de las personas más poderosas del mundo entre los siglos $\mathrm{V}$ a.C y XVIII d.C. no creo que fuera muy diferente entre sí. Tampoco en el caso de los más pobres. La concentración del poder (y la falta de libertad aparejada) a lo largo de los siglos impidió el progreso de la humanidad. Condenó a los más pobres a una vida llena de sufrimiento y a los más ricos a una vida mucho menos cómoda que la que disfrutamos actualmente la mayor parte de la población de la Unión Europea. Y el cambio ha tenido lugar en menos de dos siglos. Es decir, a medio plazo, hasta los más poderosos salen beneficiados del reparto del poder político y económico.

Por lo expuesto hasta ahora podemos concluir que la concentración de poder es muy negativa para la economía, el desarrollo social y la mejora de la calidad de vida de las personas. Ahí incluiría yo al medioambiente. Y el cambio climático 
también afectará muy negativamente a los muy ricos, aunque, como siempre, el impacto será infinitamente peor para los más pobres.

Veámoslo ahora desde la otra perspectiva. ¿Por qué es bueno tener un sistema adecuado de distribución de la riqueza?

En primer lugar, ya hemos comentado que el poder económico puede corromper al poder político y doblegarlo conforme a sus intereses, como de hecho hace a menudo. En algunos países es muy corriente ver a grandes empresarios presentarse a las elecciones y las grandes multinacionales influyen en los políticos financiando sus campañas o mediante lobbies. Por lo tanto, un mayor grado de igualdad económica de los ciudadanos es condición necesaria para la existencia de una democracia real. Esto es importante, puesto que, en principio, todas las corrientes económicas actuales defienden la democracia como sistema político. Por lo tanto, en buena lógica, todo aquello que pueda dañarlas debiera ser eliminado.

En segundo lugar, la distribución de la riqueza permite modificar el volumen de consumo y las pautas de consumo. Una economía donde el dinero se concentra en pocas manos depende mucho de cómo gasten el dinero esos pocos. Pueden llevarse el dinero a otro país para invertirlo en economías más dinámicas, por ejemplo. Aunque quisieran gastar en su país, no podrían hacer crecer el consumo de forma eficiente de la misma manera que si el dinero estuviera más repartido. Por ejemplo, una persona, por rica que sea, no tiene sentido que vaya a la peluquería 20 veces al día, a comer a restaurantes 12 veces al día y se compre 500 pantalones y 2.000 botellas de leche. Es el dinero en manos de los hogares lo que genera la actividad económica. Los ricos solo dinamizan unos pocos sectores económicos de consumo relacionados con el lujo o ciertos segmentos del mercado inmobiliario. En cualquier caso, al beneficiar a la economía en su conjunto, las clases más pudientes también se benefician a medio plazo del proceso redistributivo.

En tercer lugar, como hemos dicho, la capacidad de consumo de grandes capas de la población impulsa la innovación y promueve el avance tecnológico. Si los teléfonos móviles no pudieran producirse y venderse en cantidades masivas, ¿habría evolucionado como lo ha hecho el sector de las telecomunicaciones? Si las personas no pudiesen comprarse los medicamentos, ¿se investigaría con la misma intensidad en la búsqueda de nuevos fármacos? Una vez más, se trata 
de beneficios que disfrutamos todos, multimillonarios incluidos. Pensemos que Felipe II era comparativamente aún más rico que Felipe VI y sin embargo no tenía ni teléfono fijo ni luz eléctrica.

En cuarto lugar, la mayor igualdad en términos de riqueza es uno de los factores que más influye en el bienestar social. Incluso en sociedades pobres, si lo poco que hay está bien repartido, las personas se consideran más felices que en otras sociedades donde todos tienen más bienes pero algunos individuos tienen muchos más bienes que otros. Pensemos, por ejemplo, en las tribus bosquimanas y similares. Desde luego, el PIB como medida de bienestar social es un absurdo. El caso es que una sociedad más igualitaria es una sociedad más cohesionada, con mayor estabilidad social, más seguridad ciudadana, más confianza. $Y$ de esta situación también se benefician los más ricos. Ningún multimillonario puede, por sí solo, mejorar la estabilidad social. Eso solo lo puede hacer el Estado. La falta de cohesión social, la desintegración de la comunidad y la existencia de capas de la sociedad empobrecidas y marginadas acaban creando gran inseguridad. No solo no es agradable y es peligroso visitar los barrios donde viven los más desfavorecidos, sino que, llegados al extremo, es peligroso circular por las calles y los ricos se ven obligados a vivir en urbanizaciones amuralladas y con vigilantes armados, como ocurre en numerosos países.

En quinto lugar, menores tasas de desigualdad implican una sociedad más confiada y más sana, lo que tiene también repercusiones económicas importantes, pues el entorno para realizar negocios es mejor y hay más mano de obra de calidad disponible.

En sexto lugar, en los países o regiones con mayor igualdad es donde más se protege al medioambiente. Posiblemente se deba a que la cohesión social favorece la acción colectiva necesaria para defender los intereses comunitarios en defensa del medioambiente. También es posible que los ciudadanos, al disponer de suficientes medios económicos, puedan participar en asociaciones ecologistas o ayudar en su financiación. Además, es lógico que los ciudadanos defiendan lo que consideran que es suyo. Si una empresa multinacional cuyos accionistas de referencia viven a miles de kilómetros quiere destrozar un paraje natural local para hacer una mina, solo una comunidad cohesionada, sin presiones por encontrar un empleo en la mina, puede hacerle frente. 
En séptimo lugar, cuando los recursos se concentran en pocas manos se realiza una inversión ineficiente de los mismos y se generan crisis económicas y financieras. Las clases adineradas acaparan grandes cantidades de dinero, que tienen que invertir en los activos disponibles, generándose burbujas en los mercados bursátiles e inmobiliarios. Se produce un incremento de las actividades financieras especulativas que detraen recursos de la economía real. El resto de la población, con pocos ingresos, tiende a endeudarse. Al final, el consumo cae, también la rentabilidad de las inversiones y se produce una crisis económica y financiera que requiere la intervención del Estado. Por lo tanto, evitar la concentración de riqueza en pocas manos es fundamental para la estabilidad del sistema económico y financiero actual, lo que redunda en beneficio de todos, incluidos los multimillonarios.

No obstante lo anterior, hay que reconocer que los beneficios mencionados se perciben en el medio plazo, no son inmediatos, y difícilmente se percibe la relación causa-efecto. Lo que sí es inmediato es que te obliguen a subir el salario de los empleados o a pagar impuestos. Además, la redistribución de la riqueza implica pérdida de poder y hace peligrar el statu quo, pues aumenta la movilidad social. Por eso, los que ostentan el poder en un momento dado siempre criticarán las políticas redistributivas. Además, si bien la redistribución mejora en términos generales la marcha de la economía, a los monopolios de consumo básico, como la electricidad, apenas les afectará. Estas empresas tienen sus ingresos asegurados $\mathrm{y}$, a igualdad de ingresos, preferirán pagar menos impuestos. Por otro lado, las empresas exportadoras tampoco se beneficiarán del aumento del consumo interno, por lo que no les interesa que se implemente una política redistributiva. A estas empresas no les importa que la economía nacional esté deprimida, lo que les importa es que sus costes de producción sean bajos, incluidos los costes laborales (lo que incide negativamente en el consumo nacional) y que en el extranjero sí haya mercados en los que los consumidores puedan adquirir sus productos. En este sentido, durante la época colonial, a las empresas de las metrópolis lo que les interesaba de las colonias era obtener materias primas baratas y un mercado donde vender los productos manufacturados, mientras que en las fábricas nacionales trabajaba mano de obra en condiciones infrahumanas. 
Vemos que las ventajas de vivir en una sociedad sin grandes diferencias en cuanto a renta y riqueza es importante y depara muchas ventajas que influyen directamente en la calidad de vida de los ciudadanos. Por otro lado, cabe cuestionarse por qué es tan complicado que personas que ingresan 10 millones de dólares al año contribuyan, al menos, como todas las demás al sostenimiento del gasto público. La respuesta hay que buscarla en la psicología humana y, en el fondo, no es tan obvia como pudiera parecer. Así, los economistas conductuales como Kahneman han descubierto que nuestra percepción de las ganancias y las pérdidas no son iguales. Si ganamos 10, nos alegramos un poco. Pero si perdemos 10, nos entristecemos muchísimo. Tal vez sea por eso que los multimillonarios se encuentren siempre deseosos de ganar más, para evitar que su patrimonio disminuya, por mucho patrimonio que tengan ya. O no quieran verse como perdedores dejando a sus hijos en herencia menos de lo que ellos recibieron de sus padres. Por otro lado, la motivación que mueve a las personas multimillonarias no siempre es el tener más dinero, sino el hecho de ganarlo, como dijo Juan March. Luego está el poder que da ese dinero, que es también muy adictivo, y que puede ser positiva para la persona (o no) pero siempre es negativa para la sociedad. Curiosamente, se ha demostrado que las personas que trabajan con temas económicos son menos generosas que el resto y que es la propia mención de la palabra "dinero" la que nos hace ser a todos más egoístas. Finalmente, podemos aventurar que cada uno de nosotros vivimos en una burbuja junto con nuestro grupo social y desconocemos los problemas y motivaciones del resto de la sociedad, siendo la burbuja de los multimillonarios aún más extrema, lo que explicaría su comportamiento antisocial en numerosas ocasiones, a lo que hay que sumar el posible "pique" o competición entre multimillonarios por ver quién tiene más.

En cualquier caso, desde mi punto de vista, y dado el objetivo del papel del Estado en la Economía, no es necesario disponer ni de decenas ni de cientos de millones de euros en la cuenta corriente para ser feliz. Es más, el hecho de tener un patrimonio multimillonario y los ingresos correspondientes no garantiza en absoluto una vida feliz. Así que, en esta línea de pensamiento, está más que justifica una acción redistributiva que suponga gravar el patrimonio y la renta de los más ricos. 
Seguramente, llegados a este punto más de uno pensará que tengo fijación con esto de que los más ricos paguen impuestos. En realidad, con independencia de la necesidad de aportar al erario público, el verdadero problema que veo yo es el ya repetido de la concentración de poder. Por eso insisto en que el concepto de "rico" que manejo no es el que empleamos usualmente. Para mí, el rico es el que escapa a las inspecciones de Hacienda, el que tiene su dinero en un paraíso fiscal y se ampara en las amnistías fiscales. Si acabas pagando a Hacienda el $50 \%$ de lo que ganas o más, no eres rico. El verdadero rico paga bastante menos. Y el problema no es el hecho de la riqueza por sí misma, siempre y cuando se haya obtenido de forma ética y legal (que no es el caso en numerosas ocasiones), sino el poder que confiere esa concentración de riqueza. En realidad no somos conscientes de que las cuasi-democracias en las que vivimos los países occidentales están siendo constantemente manipuladas y dirigidas cual títeres por ciertos grupos de presión. Es impresionante ver las redes de poder que controlan la economía y la sociedad. Los vínculos de los medios de comunicación con las grandes empresas y familias pudientes. La presencia de los fondos de inversión en todas las empresas. Las relaciones entre políticos y empresas. En muchos países europeos, las mismas empresas se vienen manteniendo en el olimpo de las compañías más grandes durante décadas gracias a sus contactos políticos. Y las familias que movían los hilos antaño, hace siglos, siguen ahí. A nivel nacional e internacional. En resumidas cuentas, el poder económico está realmente muy concentrado y, si bien da cierta autonomía a los políticos, hay ciertas líneas que no se les permite traspasar. Pero soy optimista. No creo en teorías de conspiraciones. El club de los ricos no es un grupo homogéneo y está formado por personas de diferentes sensibilidades políticas. $Y$ no se trata necesariamente de malas personas, si bien viven en mundos paralelos al nuestro. Así que, por un lado, este grupo de personas puede evolucionar y adherirse a las nuevas teorías económicas que propugnan más igualdad y, por otro, los enfrentamientos entre ellos dan pie a que ceda la presión política en otros asuntos y se pueda avanzar hacia una mayor cohesión social. 
Para acabar con este punto, simplemente recordar que la distribución de la riqueza es necesaria no solo desde una argumentación basada en la ética y el bienestar de las personas, sino también desde un punto de vista objetivo que busque garantizar la eficiencia económica. La concentración del poder económico socava los sistemas democráticos, destruye los mercados de competencia perfecta, afecta negativamente a los recursos humanos, reduce la innovación, fomenta las externalidades negativas relacionadas con la contaminación y el cambio climático, debilita el consumo y el crecimiento económico, incrementa la actividad financiera especulativa y la asignación ineficiente de recursos y desencadena crisis económicas y financieras.

\subsection{MEDIDAS DE DISTRIBUCIÓN}

Una vez ha quedado claramente justificada la necesidad de intervención del Estado para redistribuir la riqueza, vamos a pasar a describir algunos de los mecanismos que puede usar el Estado para lograr este fin. Algunos de ellos ya han sido mencionados. En primer lugar, trataremos los mecanismos que favorecen la distribución inicial de la renta. En segundo lugar, en el próximo epígrafe, nos centraremos en las políticas de redistribución. Empezaremos analizando los impuestos, diferenciando especialmente entre los que gravan la renta o la riqueza y subrayando la importancia de gravar ambas, para, a continuación, tratar la redistribución mediante políticas de gasto y exponer brevemente qué es la renta vital básica.

Recordemos que, tal y como hemos definido más arriba, hablamos de distribución cuando nos referimos a cómo se reparte la "tarta", es decir, los ingresos generados por la venta de productos y servicios, entre las personas que, de alguna manera, han participado en su elaboración. Bien, para ver cómo se reparte, lo primero que hay que ver es quién participa en la producción y qué es lo que aporta. 
Podemos dividir a los que participan en la producción en dos grupos: los trabajadores, que aportan su fuerza de trabajo, es decir, su esfuerzo, energía, tiempo, conocimientos y talentos, y los capitalistas, que aportan los recursos materiales y financieros necesarios. Desde esta perspectiva, ambos grupos son necesarios y de esta forma se establece una negociación por el reparto de las ganancias. En realidad, esta forma colaborativa de ver la empresa no es la que predomina y generalmente no se contempla la colaboración entre empresario capitalista y trabajadores, sino que se los trabajadores suponen meramente un input más, un coste que hay que minimizar para aumentar el beneficio del socio capitalista quien, a cambio de su inversión, es el dueño de la empresa. Así, los dueños de las acciones, quienes en numerosas ocasiones ni siquiera han contribuido a la financiación de la empresa (sic) y no visitan las instalaciones productivas, se convierten en la parte más importante del binomio trabajo-capital, o, mejor dicho, la única parte. Así, desde las teorías de dirección financiera se enseña que el objetivo de la empresa es maximizar el beneficio de los accionistas, tal cual. Por lo tanto, se está defendiendo que la "tarta" debe ser para los accionistas, mientras que los trabadores son, en realidad, la leche o la harina. En estas circunstancias, en las que un grupo ve justificado quedarse con toda la tarta, es lógico que el Estado tenga que actuar.

La materialización de este "reparto" entre capitalistas y trabajadores se puede analizar a través de la evolución de la llamada "masa salarial". Pues bien, en las últimas décadas, el análisis muestra una pérdida del poder negociador de los trabajadores, es decir, los capitalistas se están llevando un trozo de la tarta cada vez mayor. Esta situación se debe a diferentes factores y políticas llevadas a cabo por los propios Estados, encaminadas directamente a reducir el poder negociador de los trabajadores. Dentro de este mismo ámbito, el proceso de globalización auspiciado por los Estados aumenta enormemente el poder negociador de los empresarios, quienes pueden mover la ubicación de las plantas de producción a lugares del mundo con menor coste de mano de obra. $\mathrm{Y}$, especialmente en los últimos años, se está poniendo en relieve el proceso de automatización y uso masivo de robots, que puede tomar un impulso impredecible con la tecnología 5G, que tendrán como consecuencia la reducción de su demanda de trabajo. 
En este contexto, las formas de actuación tradicionales van dirigidas a obligar a dar una porción a los trabajadores, por un lado, y a mejorar su capacidad de negociación con los socios capitalistas, por otro lado. En el primer grupo encontramos medidas como el salario mínimo, la pensión de jubilación obligatoria, así como otras medidas relacionadas con la protección e higiene en el trabajo, que reducen los costes que debe asumir el trabajador por el hecho de trabajar, como costes relacionados con pérdida de salud. Ahí entran también el control de la jornada laboral, los periodos de descanso y las vacaciones. En el segundo grupo destacan el derecho de sindicación, el derecho de huelga el derecho de manifestación, la prestación por desempleo y ciertas subvenciones. Más adelante nos centraremos en el papel que desempeñaría una medida como la renta vital básica.

Exceptuando la renta vital básica, todas las herramientas de intervención del Estado mencionadas son bastante ortodoxas. Se trata de repartir la tarta de forma más equitativa: tanto los trabajadores como los capitalistas participan de alguna manera en el proceso productivo y merecen su parte. Pero, frente a esta visión ortodoxa, algunos economistas se han realizado la siguiente pregunta: ¿Realmente es necesaria la participación del capitalista? ¿No sería más sencillo que, directamente, las empresas no necesitaran de socios capitalistas? Al fin y al cabo, ¿qué aportan los capitalistas? Tierra y dinero. Pero, ¿acaso el Estado no puede aportar ambos recursos, o los propios trabajadores? La idea que subyace a esta visión es que, por un lado, el hecho de estar en el lado de los capitalistas o en el de los trabajadores es una cuestión de suerte y depende en gran medida del lugar de nacimiento. Por otro lado, el origen de los recursos de los capitalistas no siempre es fruto de su trabajo y tesón, ni es ajeno a actuaciones reprobables. Además, los que menos aportan, en términos de esfuerzo y sacrificio y tiempo, son los capitalistas. Para colmo, son los que más se benefician, pues obtienen los beneficios de su inversión durante largos años, y luego sus descendientes. De hecho, pueden reinvertir los beneficios que han obtenido sin esfuerzo y perpetuarse como capitalistas. Como consecuencia de todo esto se produce la concentración de poder tan nefasta que hemos comentado (y que ya predijo Marx). Dentro de esta línea argumental, se razona que hay diferentes formas en las que el Estado puede influir en el sistema productivo de forma que se minimice la posición de poder que ostenta el 
capitalista en la actualidad. Se trata de redistribuir la propiedad de la tierra, fomentar instituciones colectivas como las cooperativas, defender la economía colaborativa y repensar la gestión del dinero y su capacidad para financiar proyectos productivos. También hay opciones muy interesantes, como la defendida por Montero de Burgos en su obra "Propiedad, Capital, Trabajo" en la que propone un concepto evolutivo de la propiedad de los medios de producción y su aplicación a la reforma de la empresa.

La propiedad de la tierra es un elemento fundamental en la economía, y muy especialmente en las economías agrarias y rurales. También es importante en el sector inmobiliario. Y en el sector de la extracción de minerales. Actualmente, en muchos lugares del mundo existen grandes terratenientes que poseen enormes propiedades. En Europa, esta situación se debe, por ejemplo, a la apropiación de las tierras comunales por parte de la aristocracia. En España, el propio proceso de la Reconquista, hace algunos añitos ya, desempeñó un papel importante para explicar la situación actual. A este respecto cabe señalar que los terratenientes españoles, muchos de origen nobiliario, son las personas más beneficiadas en España por las subvenciones de la Política Agraria Común de la Unión Europea. En otros países del mundo son grandes inversores, generalmente extranjeros, como los fondos soberanos, los que están adquiriendo inmensas propiedades, en muchos casos, robando a las malas la tierra a las comunidades locales y cometiendo atrocidades y vulneraciones de los derechos humanos con el consentimiento del Gobierno del país. Pues bien, esta distribución de la tierra no es la única posible ni es la más eficiente. De sobra son conocidos los problemas económicos y ecológicos que generan los monocultivos, por nombrar un ejemplo. EL Estado debiera favorecer diferentes formas de posesión y gestión de la tierra que involucre la propiedad privada, los bienes comunales y la gestión estatal. Así, los trabajadores de la tierra no tendrán que estar necesariamente a merced del propietario de la tierra, lo cual ha sido y es lo más corriente en muchos países en vías de desarrollo.

La otra aportación principal del capitalista es el dinero, la financiación del proyecto empresarial. Es cierto que si se quiere poner en marcha una empresa también se puede acudir a las entidades financieras, pero esto no está al alcance 
de todos. Cuanto más dinero se tiene, más fácil es obtener un préstamo bancario. De hecho, las cajas de ahorro y los microcréditos surgieron precisamente para facilitar el acceso al crédito a grandes masas de población que quedan excluidas del sistema financiero. En estas circunstancias, nos encontramos en una situación en la que "el dinero llama al dinero". Además, contrariamente a lo que se cree, la menor parte del dinero de los bancos no va a financiar actividades productivas. Pero, ¿qué pasaría si hubiera mayor facilidad de acceso al crédito? Por ejemplo, a través de una banca pública, como la que existe en numerosos países. O que se pudiera recurrir a garantizar las aventuras empresariales con activos como la vivienda, como ocurre en países con gran número de emprendedores en los que existe la "dación en pago" y el empresario no responde ante el banco "con todos sus bienes presentes y futuros". O que aparecieran otras vías para obtener financiación, como el crowdfunding o el crowdlending. Entonces, al menos en los mercados de competencia perfecta, habría probablemente muchos más "pequeños capitalistas" que, con sus proyectos empresariales, fomentarían el crecimiento económico al margen del gran capital.

Otra opción es fomentar formulas empresariales diferentes a las capitalistas, como las cooperativas, junto con otras organizaciones productivas pero que no tienen ánimo de lucro o que defienden la economía colaborativa. O modificando las características de los activos financieros, acciones y bonos, por ejemplo limitando la vida de las acciones para que no tengan derechos políticos y económicos indefinidos sino que tengan caducidad, como ya ocurre con los derechos de propiedad intelectual. O regulando cómo se deben repartir los dividendos empresariales entre los propietarios, los trabajadores y la propia empresa, como propuso el presidente francés Sarkozy en 2011.

Por otro lado, en el mundo actual, con un desarrollo tecnológico sin precedentes, el auge de las telecomunicaciones, la independencia energética, el software y el hardware libres de código abierto, las impresoras 3-D y la invasión de los robots, las relaciones entre el trabajo y el capital se van a transformar radicalmente. Por un lado, se requerirá menos capital para crear algunos tipos de empresas, lo cual es a priori positivo y puede ayudar a que las personas trabajen en lo que deseen y desarrollen su potencial. Pero, por otro lado, si la mayor parte de la producción 
la realizan los robots (actualmente ya existen camiones autónomos, robots ordeñadores y robots camareros, por no hablar de los robots empleados en el sector manufacturero), las empresas demandarán menos trabajo, lo que presionará a la baja los salarios y deprimirá la economía, pues no se podrá vender la producción. $Y$ esto será así porque no se podrán crear empleos en otros sectores al mismo ritmo al que se van a destruir empleos en los próximos años. El Estado, puede participar directamente en la producción o tendrá que modificar toda la estructura impositiva y de redistribución mediante una renta vital básica o como empleador de último recurso, por ejemplo.

Un factor que influye de forma muy poderosa en la distribución de la renta entre capitalistas y trabajadores, pero que pasa desapercibido, es la política monetaria y el propio diseño del dinero. $Y$ es que el diseño del dinero tiene un impacto enorme en cómo se distribuye, lógicamente. En la actualidad, el dinero lo crean los bancos o el Banco Central y son ellos los que deciden a quién se lo van a regalar, aunque, obviamente, no se exprese en estos términos. Es importante resaltar que estamos hablando de cómo se crea el dinero de la nada y que en este proceso no se está generando riqueza, en el sentido de bienes o servicios. También es importante subrayar que la situación actual no es la única posible y que hay otras alternativas. Hablamos del funcionamiento del sistema monetario y financiero en su conjunto, que afecta también a la economía real. Se trata de un tema muy complejo, lleno de interacciones, del que solo voy a esbozar unas ideas interesantes.

La primera idea es muy breve. Los bancos conceden préstamos a quienes ellos consideran dignos de crédito. Si resulta que no les devuelven el dinero, el banco pierde. Pero, ¿qué ocurre si al gerente / consejo de administración del banco le da igual perder? Esto puede suceder, como en el caso de las Cajas de Ahorro o el de los bancos sistémicos, si piensan que serán rescatados y el Estado asumirá sus pérdidas. $O$ si las pérdidas suponen poca cosa. Lógicamente, si al banco no le preocupan las pérdidas, puede otorgar préstamos (crear dinero) que no cobrará, es decir, puede crear dinero (sic) y regalarlo a sus amigos (empresas o personas físicas). Crear y dar 100 millones de euros y perderlos (es decir, regalar 100 millones de euros) es poco para un banco, pero para una persona física o empresa recibirlos sí que marca una gran diferencia. Pues los bancos lo pueden 
hacer y lo hacen. Por ejemplo, en España hasta hace relativamente poco (hasta que se prohibió) era habitual que condonaran la deuda a los principales partidos políticos.

Ahora pensemos en la política monetaria y la situación actual. Desde la crisis financiera de 2008, los bancos centrales han inyectado en el sistema bancario varios billones de dólares. ¿Se han destinado a financiar proyectos empresariales? No, han acabado en la bolsa, para comprar renta fija y renta variable. Se ha generado de esta manera una burbuja bursátil de enormes proporciones hinchada por la actuación de los bancos centrales. ¿Por qué los bancos centrales han dado estas cantidades ingentes de dinero a los bancos? Se trata de una decisión política, obviamente. De igual manera hubieran podido repartir el dinero entre los ciudadanos y de esa forma el dinero sí que habría acabado en la economía real. Sin embargo, la opción política elegida es la de hacer crecer artificialmente el valor de los activos financieros, beneficiando, obviamente, a los propietarios de bonos y acciones, entre los que se encuentran pocas personas pobres. Se trata de una distribución de recursos de primera magnitud, pero que pasa desapercibida. Estamos hablando de billones de dólares que son engullidos por los mercados financieros. Es importante recordar que los bancos centrales crearon este dinero de la nada, pues eso es algo que pueden hacer sin problemas, y lo han utilizado para favorecer los intereses de los grandes inversores internacionales. ¿Por qué no canalizan el dinero de nueva creación hacia bancos públicos que lo empleen para financiar proyectos empresariales? Además, y esto debe quedar muy claro, el dinero invertido en bolsa, salvo en las muy contadas ocasiones en las que una empresa emite bonos o acciones en el mercado primario, no sirve para financiar a las empresas. Se supone que los Bancos Centrales, que en la mayoría de los casos son independientes de los Gobiernos elegidos democráticamente, son apolíticos y se basan exclusivamente en criterios técnicos. No obstante, estas decisiones tienen un contenido altamente político e ideológico. Si se tienen que valorar las decisiones de los bancos centrales en función de los objetivos que deben alcanzar, todos suspenderían. Han generado deflación (a pesar de haber creado enormes cantidades de dinero, que no ha llegado a la economía real), mayor riesgo sistémico en el sistema financiero internacional debido a la concentración bancaria, una volatilidad enorme en los mercados financieros, han alimentado 
burbujas financieras y privado de financiación a la economía real limitando el crecimiento económico... vamos, que se han lucido. Pero si el objetivo no confeso es otro, el de evitar las pérdidas económicas a los grandes inversores, la situación es muy diferente y sí que se les puede aplaudir.

Las grandes empresas multinacionales han podido emitir ingentes cantidades de bonos, que han sido adquiridos por las instituciones financieras y los Bancos Centrales. Esto ha supuesto enormes entradas de dinero líquido para estas empresas, que han destinado, no ha proyectos de inversión, sino principalmente al pago de dividendos a los accionistas, la adquisición de otras empresas o la adquisición de sus propias acciones en los mercados bursátiles. Como consecuencia, se ha producido, se está produciendo, una burbuja financiera especulativa de una magnitud sin precedentes capaz de desestabilizar todo el sistema financiero internacional. Los beneficiados son los accionistas, que cobran dividendos y aumentan su patrimonio, y los directivos de las empresas, que cobran cientos de millones si el valor de las acciones sube, si pagan dividendos y también si sucede todo lo contrario (sic). $\mathrm{Y}$ también los intermediarios financieros, que se llevan buenas comisiones con toda esta operativa. En resumidas cuentas, un grupo relativamente reducido de la población está acaparando miles y miles de millones de dólares y euros gracias a la política monetaria de la FED y el BCE. Un proceso de concentración de riqueza y patrimonio sin precedentes promovido desde el propio Estado. La pregunta del millón es: ¿Qué pasará cuando las empresas endeudadas no puedan devolver el dinero que tomaron prestado? ¿Habrá otro rescate público? ¿Quién lo pagará?

Finalmente, es necesario mencionar las numerosas monedas que se están creando para ser utilizadas junto con la divisa oficial. No se trata solo de criptomonedas, sino de monedas de toda clase. Estas monedas también pueden influir enormemente en la distribución de la riqueza y tienen un potencial que aún es difícil vislumbrar, pero que es muy prometedor aunque no exento de dificultades. Los Estados harían bien en estudiar cómo diseñar estas nuevas monedas (cómo se crean, cómo se usan y demás características) y utilizarlas para crear un nuevo sistema financiero más eficiente, en lugar de intentar eliminar absolutamente el uso del dinero en efectivo, lo que daría aún más poder 
a los bancos. Debemos recordar que, actualmente, los que tienen realmente el poder de crear moneda son los bancos privados (junto con los Bancos Centrales), y son quienes controlan también las redes informáticas por las que se mueve el dinero, los sistemas de transferencia de fondos. Demasiado poder que está cada vez en menos manos, fuera del alcance del control democrático.

La intervención del Estado en la fase de distribución puede llegar a ser muy significativa. Esta intervención se hace, como se ha comentado, mediante actuaciones legislativas, regulando las relaciones entre las empresas y los trabajadores, y mediante la política monetaria. Pero la tendencia actual es que el papel desempeñado por el Estado en esta fase, así como en la fase de redistribución que explicaremos a continuación, tenga cada vez menos incidencia en el reparto de la "tarta", de forma que no impida la acumulación de riqueza y poder en manos de las grandes fortunas.

\subsection{MEDIDAS DE REDISTRIBUCIÓN}

Una vez el dinero ha sido asignado entre capitalistas y trabajadores, el Estado suele actuar con políticas de redistribución. Estas políticas, en principio, tienen como principal objetivo crear un contexto económico y social favorable para los ciudadanos, evitando situaciones de pobreza y penuria. También se pueden emplear en pos de la igualdad de oportunidades, para luchar contra situaciones de extrema desigualdad y evitar acumulación de poder excesiva por parte de individuos y empresas. En definitiva, se trata de corregir el resultado de la distribución primaria de la renta que hemos comentado en el epígrafe anterior, modificando la porción de la "tarta" que recibe cada uno.

Para ello, el Estado dispone de diversos instrumentos de política redistributiva que inciden sobre los ingresos y los gastos del Estado. En cuanto a los ingresos, el principal instrumento son los impuestos. Por la parte del gasto, existen políticas diversas de redistribución directa e indirecta. Además, comentaremos una propuesta redistributiva que, no por ser muy antigua deja de ser interesante: la renta vital básica. Se trata de tres temas (impuestos; redistribución directa e 
indirecta; renta básica) de enorme importancia para entender la concepción del Estado y quién detenta realmente el poder dentro de él. Pero se trata de temas muy extensos que solo vamos a poder tratar de manera muy superficial, con el ánimo de despertar el interés en el lector.

\subsubsection{LOS IMPUESTOS Y SU FUNCIÓN REDISTRIBUTIVA}

Los impuestos han existido desde que existen los Estados. Un Estado requiere de una estructura que hay que mantener y unos gastos que hay que sufragar. Antiguamente, el principal gasto del Estado era de naturaleza bélica, el mantenimiento del ejército. $Y$ esto ha sido así hasta hace relativamente muy poco tiempo, con el advenimiento de la teoría keynesiana en el siglo $X X$, según la cual el Estado puede y debe intervenir y participar en los mercados de bienes y servicios, así como desarrollar una política redistributiva en favor de los más desamparados. Así, los presupuestos estatales experimentaron un crecimiento espectacular a partir de la Segunda Guerra Mundial con motivo de la confrontación militar, y ese nivel de gasto se mantuvo después, a pesar de reducirse el gasto bélico (que sigue siendo muy importante en algunos Estados). Para poder hacer frente a todo ese gasto, los principales ingresos con los que cuentan los Estados son los impuestos.

En la actualidad los impuestos cumplen diversas funciones. Por un lado, siguen siendo fundamentales para sufragar las políticas estatales. Por otro lado, como ya se ha comentado, son un instrumento de estabilidad macroeconómica. Además, permiten incentivar o penalizar actividades económicas, de forma que se regulan indirectamente los mercados de bienes y servicios. A efectos de la política redistributiva, que es lo que nos importa en este punto y a la que vamos a circunscribir el análisis de los impuestos, determinan quién y cómo debe participar en el sostenimiento del gasto público.

Históricamente, no todos los grupos sociales han pagado impuestos. Analizar quién paga más impuestos y quién menos nos permite identificar las relaciones de poder en una sociedad. Porque, obviamente, a nadie nos gusta pagar impuestos, pero solo algunos grupos sociales, los que detentan el verdadero 
poder, son capaces de presionar al Estado para reducir al máximo su aportación a las arcas comunes mediante diversos instrumentos y opciones que solo están a su disposición. Esto ha sido y sigue siendo así en estos momentos. De hecho, aunque se tiene la intuición de que las personas más acaudaladas son las que más impuestos pagan (en términos relativos o absolutos), eso sencillamente no es así. La realidad muestra que las grandes empresas y las grandes fortunas apenas contribuyen al sostenimiento de los gastos comunes, que se aprovechan de la libertad de circulación de capitales a nivel mundial (promovida por unos Estados influidos por los lobbies financieros y las grandes fortunas) la existencia de paraísos fiscales (idem) o incluso amnistías fiscales. Esta situación nos hace constatar el fracaso cosechado en lo relativo a otro de los objetivos deseables de los impuestos: favorecer la igualdad de oportunidades. Es decir, quitar a los que más tienen y acumulan y evitar la concentración excesiva de poder económico. Subrayo una vez más lo extremadamente nocivo que es para una sociedad democrática la concentración de poder, incluido el poder económico. Este poder se puede usar, por ejemplo, para evitar el pago de impuestos pero, no obstante, beneficiarse de las políticas que hacen uso de esos impuestos, como subvenciones a empresas o contratos públicos. El peligro es tan grande, que ni se ve.

Según la visión comúnmente aceptada actualmente, los sistemas tributarios deben ser progresivos (que aporten relativamente más los que más tienen). Algunas voces defienden incluso el establecimiento de una renta máxima, es decir, que ninguna persona pueda ganar más de cierta cantidad neta anual. Esta opción no se ha implementado en ningún país, pero sí que es cierto que en EEUU tras la Segunda Guerra Mundial el tipo marginal en el Impuesto sobre la Renta alcanzó durante muchos años el $90 \%$. Esto es, a partir de cierta cantidad, de lo que ganaba una persona el Estado se quedaba el 90\%. Es interesante recalcar que ese fue el periodo de mayor crecimiento económico experimentado en los últimos 100 años y en el que hubo menos desigualdad en EEUU. No es posible determinar que ese crecimiento económico se debiera a esta política impositiva, pero lo que sí se puede afirmar con rotundidad es que impuestos elevados a las clases más pudientes no implican necesariamente menor crecimiento económico. Es decir, que no es cierto que subir los impuestos a los ricos sea 
malo para la economía. El caso es que, como ya hemos visto, los países con mayor calidad de vida son aquellos en los que se pagan más impuestos y donde hay menos desigualdades entre ricos y pobres. Por otro lado, desde la perspectiva que defiendo en este ensayo, una persona necesita un contexto para ser feliz, pero dicho contexto no exige tener un patrimonio ni ingresos millonarios, por lo que unos impuestos muy elevados a partir de ciertos niveles no resultan dañinos para las personas y su felicidad. Incluso, desde la visión de ciertas religiones, como la cristiana, sería muy positivo.

Los impuestos gravan las diferentes manifestaciones de capacidad económica. Así existen impuestos que gravan la renta percibida (Impuesto sobre la Renta de las Personas Físicas, el Impuesto de Sociedades etc.), otros que gravan la acumulación de patrimonio (Impuesto sobre el Patrimonio, Impuesto de Sucesiones y Donaciones etc.), y otros gravan el consumo (Impuesto sobre el Valor Añadido, Impuesto sobre Hidrocarburos, Impuesto sobre Bebidas Alcohólicas etc.). La cantidad de impuestos que existe es enorme y la casuística a nivel internacional, inabarcable. Los impuestos que gravan la renta y el patrimonio se denominan impuestos directos, pues permiten considerar circunstancias personales del sujeto pasivo (el que paga el impuesto) cuando se calcula lo que debe pagar. Los impuestos que gravan el consumo pertenecen a los impuestos indirectos, y todas las personas pagan lo mismo, con independencia de que sean ricas o pobres.

Un aspecto importante de la política tributaria es determinar qué manifestaciones económicas se quiere gravar y con qué intensidad. Se trata de una decisión política de primera magnitud. No es una cuestión meramente técnica. Obviamente, sea cual sea la respuesta, necesariamente beneficiará a unos y perjudicará a otros. Y es que hay que tener en cuenta que, en la actualidad, el Estado tiene una estructura de gasto muy rígida, es decir, resulta muy complicado por razones políticas reducir el gasto global (aunque a todos se nos ocurren partidas de despilfarro que se podrían eliminar sin problemas, existen grupos de presión que impiden su eliminación, por lo que solo se eliminarán si la presión del "grupo atacante" es mayor que la del "grupo defensor". Por cierto que esta dinámica ataque-defensa es fundamental para entender la política en 
general). Por lo tanto, el Estado intentará siempre recaudar con los impuestos una cantidad equivalente a ese gasto, con el fin de no incurrir en déficit. Es decir, que para que unos paguen menos impuestos, otros tendrán que pagar más. Incluso si se pudiera reducir el gasto público, habría que decidir quién se va a beneficiar de la bajada de impuestos. Por ejemplo, durante el Gobierno de Zapatero (PSOE) fueron las grandes empresas las que se beneficiaron de la bajada del impuesto de sociedades. Y, cuando la crisis económica impulsó al Estado a subir los impuestos, tanto PSOE como PP subieron significativamente el IVA, que pagan por igual pobres y ricos, si bien en términos relativos afecta más a los pobres. Tampoco se planteó la introducción de un IVA más elevado para los productos de lujo, que son los que consumen los más ricos. Mientras que sí se subió de forma espectacular el IVA a productos de primera necesidad. Una vez más se pone de manifiesto quién mueve los hilos del Estado.

Los impuestos más conflictivos, en el sentido de que se discute más acerca de su impacto en la economía y los ciudadanos, son los que gravan a las rentas del trabajo, las rentas del capital y las herencias y el patrimonio. Estos impuestos no afectan por igual a los trabajadores (la mayor parte de la ciudadanía) y a los capitalistas (los más ricos y que son una minoría). Los trabajadores obtienen sus rentas a través del trabajo, mientras que los capitalistas ganan su dinero gracias a su patrimonio (dividendos y alquileres), pues son propietarios de empresas e inmuebles, propiedad que en no pocas ocasiones es heredada. Téngase en cuenta que dentro del grupo de los capitalistas no entran ni los trabajadores autónomos ni los pequeños empresarios. Ni siquiera los dueños de medianas empresas, quienes trabajan en sus empresas y cuyo salario por dicho trabajo no es una parte despreciable de sus ingresos totales. Los capitalistas son los llamados "rentistas", los que ganan dinero sin que sus ingresos estén relacionados con su trabajo. A este grupo privilegiado se le pueden unir los directivos y altos cargos de las grandes empresas, por su capacidad para acumular grandes cantidades de dinero y patrimonio. Además, en no pocas ocasiones sus retribuciones no van ligadas a su desempeño, es decir, cobran cantidades astronómicas gestionen bien o mal la empresa, incluso aunque lleven a la empresa a la quiebra. 
En la actualidad, la mayor fuente de ingresos para el Estado son las rentas del trabajo. $Y$ esto sin contar las cotizaciones a la Seguridad Social que hay en muchos países, que por motivo de cómo se define legalmente un impuesto no entran dentro de esta categoría pero que, a efectos prácticos, también tienen su origen en las rentas del trabajo. Por su parte, la contribución de los otros impuestos (capitales, patrimonio, herencia) no deja de descender. Esta evolución pone de manifiesto qué clase social controla al poder Estatal. Además, el contexto financiero internacional creado por los propios Estados (libertad de circulación de capitales y existencia de paraísos fiscales) complica enormemente a los Estados la recaudación de ciertas rentas del capital y herencias, pues los más acaudalados amenazan constantemente con llevarse su dinero al extranjero. Obviamente, existen diversos mecanismos para desincentivar estas actuaciones poco solidarias, pero los grupos de presión impiden que los Gobiernos de turno ni tan siquiera se las planteen.

Lógicamente, disponemos de multitud de material teórico que avala la reducción drástica de todo tipo de impuestos, especialmente de los impuestos que afectan a los más ricos. Pero esa argumentación olvida numerosos aspectos de la realidad, como que no todos estamos en las mismas circunstancias al nacer, pues existen de partida desigualdades insalvables que han perdurado a lo largo de los siglos, o como que el ahorro producido puede no ser invertido o consumido por los ricos dentro de la economía nacional, sino que se traslade a paraísos fiscales. Por lo general, los defensores de estas teorías para eliminar casi todos los impuestos son contrarios a la política fiscal (que exige el pago de impuestos para sufragar un gran gasto público destinado en gran medida a la redistribución de la riqueza) y defienden la política monetaria, que no exige el pago de impuestos y, en su versión actual, beneficia claramente a los grandes patrimonios, como hemos comentado ya.

Concluyendo, podemos decir que, desde la aparición de los primeros Estados, los impuestos han servido para sufragar los gastos estatales. En los Estados actuales se han añadido otras funciones, de las que hemos comentado muy brevemente la función de redistribución. Contrariamente a lo que se puede pensar, en la actualidad son los trabajadores los que cargan con el peso de la 
financiación del gasto público, y su aportación sigue una senda ascendente. Lo curioso es que, como veremos a continuación, una parte cada vez mayor de lo recaudado con los impuestos acaba en manos de las grandes empresas y las grandes fortunas. Es decir, el Estado se ha convertido en lo contrario a Robin Hood, pues realiza una redistribución en sentido negativo, quitando a millones de ciudadanos que obtienen sus rentas del trabajo para regalar cada vez más dinero a los más pudientes, unos pocos capitalistas y ricos herederos de rancio abolengo. Esta evolución ha tenido efectos secundarios también nocivos para la economía, pues se han generado sistemas tributarios muy complejos y confusos para extraer los fondos que no pagan las clases más adineradas. Así se ha creado una enorme cantidad de impuestos difíciles de gestionar y que complican la existencia a ciudadanos y empresas, impactando negativamente en la eficiencia de los mercados de bienes y servicios. O se han bloqueado sistemáticamente impuestos que no afectan a los ciudadanos de a pie sino a los conglomerados financieros y que pueden frenar la especulación y la inestabilidad de los mercados financieros internacionales, amen de realizar una verdadera redistribución de la riqueza, como la llamada "Tasa Tobin". Ciertamente, no es esto lo que debe hacer un Estado, desde mi punto de vista. Pero, lo más curioso, es que muchas de las personas que se ven perjudicadas por esta evolución, los que ven cómo aumentan los impuestos que pagan, defienden un sistema impositivo que claramente les perjudica a ellos en favor de los más ricos. Es lo que se consigue cuando la acumulación de poder permite manipular la opinión de grandes masas de población durante mucho tiempo y por diversas vías.

\subsubsection{EL GASTO Y SU FUNCIÓN REDISTRIBUTIVA}

No obstante lo anterior, es necesario resaltar que en los países democráticos más avanzados, como los pertenecientes a la Unión Europea, el Estado realiza una inmensa tarea de redistribución de la riqueza hacia grandes capas de la población. Así, las partidas de gasto destinadas a las pensiones suelen absorber gran parte del presupuesto nacional, así como las destinadas a sufragar los subsidios por desempleo. 
La función redistributiva mediante el gasto público puede ser directa o indirecta. Es directa cuando el Estado entrega el dinero directamente a los interesados para que estos lo gasten a su conveniencia (pensiones, prestación por desempleo, ciertas subvenciones, rescates empresariales), y es indirecta cuando el gasto del Estado supone una reducción del gasto de los beneficiados (sanidad, educación, vivienda, subvenciones para cubrir gastos...). Además existen formas más sutiles de redistribución de la riqueza, como la realización de inversiones públicas o la contratación de empleados públicos. Y es que, de forma indirecta, todas las actuaciones del Estado implican redistribuir la riqueza.

Como hemos comentado, gran parte de la población de muchos países democráticos se ve beneficiada por las políticas redistributivas del Estado, siendo las pensiones el caso paradigmático. De no ser por esta redistribución de la riqueza (y otras subvenciones adicionales) serían las familias las que se tendrían que hacer cargo económicamente de sus mayores, como ocurría en el pasado, cuando la esperanza de vida era mucho menor. A pesar de lo positivo de la política de redistribución directa, ésta no está exenta de crítica. Efectivamente, como con toda política pública, los objetivos que se desean alcanzar deben estar claros, el Estado debiera emplear los mejores medios para alcanzar esos fines y debe evitar extralimitarse. Así, siguiendo con el caso de las pensiones y de forma extensible a las prestaciones por desempleo y otras muchas políticas directas de redistribución, ¿cuál es el objetivo que se persigue? ¿Se alcanza el objetivo? ¿Están coordinadas estas políticas a todos los niveles de la Administración Pública de forma que se evite el solapamiento y el despilfarro? Si, como defendemos en este ensayo, el papel del Estado es garantizar un contexto económico que permita a las personas desarrollarse libremente y buscar la felicidad, tal vez fueran aconsejables algunos cambios. Por ejemplo, una renta básica vital simplificaría enormemente la maraña de subvenciones existentes (con todos los problemas que comporta), eliminándolas directamente, liberando así recursos y ganándose en transparencia. Esto también afectaría a los gastos asociados al desempleo y a su gestión. También se podría reformar el sistema de pensiones. $Y$ el sistema impositivo, pues se podrían reducir impuestos a las personas jubiladas (luz, agua, IBI), de forma que con la renta vital básica se pueda tener una vejez digna sin necesidad de grandes aportaciones extraordinarias, teniendo en cuenta que el Estado se hace cargo 
de la sanidad. En fin, se trata de un tema muy complejo, con muchas ramificaciones, que solo he apuntado con el ánimo de incitar a la reflexión y mostrar que las cosas pueden cambiar.

Por lo general, debido a la manipulación a la que estamos sometidos, al hablar de política redistributiva directa de gasto pensamos en "la paguita" para los pobres, vagos y maleantes, y ni nos planteamos las ayudas a las grandes empresas y propietarios en forma de rescates, subvenciones, concesiones y contratos millonarios con la Administración Pública... Incluso pensamos que en estos últimos casos los beneficiarios sí que son dignos de la ayuda que reciben y es razonable ocasionar el pertinente quebranto al Estado.

Por otro lado, es interesante recalcar el impacto que tienen las diferentes formas de redistribución sobre la concentración de poder. En el primer caso, el de la "paguita", son muchas personas las beneficiarias y reciben cada una de ellas una cantidad muy pequeña. En el segundo caso, las ayudas van destinadas a empresas y personas concretas y el importe recibido a título personal llega a ser muy cuantioso. Por este motivo, estas ayudas fomentan la desigualdad económica y la concentración de poder. En este sentido, y esto es muy importante, debemos recordar que todo gasto público supone un ingreso privado, es decir, redistribución de la riqueza. Y si se aumenta o disminuye ese gasto público, se aumenta o disminuye el ingreso privado. Esta es la razón por la que es habitual que organizaciones de empresarios clamen contra los impuestos y el déficit y la deuda del Estado, al tiempo que exigen mayor gasto Estatal en el sector que les ataña, sean las infraestructuras, la banca, la sanidad, el turismo o la automoción.

Insistiendo sobre esta problemática, el Estado gasta mucho dinero en partidas destinadas a ayudar a empresas y todo tipo de organizaciones (partidos, sindicatos, asociaciones taurinas, la Iglesia Católica y un etcétera interminable). Todos quieren chupar de la teta del Estado. No deja de ser curioso que muchos de los que critican las ayudas a los ciudadanos justifican las ayudas a las empresas y demás organizaciones. Pero, ¿cuál es la justificación de esta redistribución de la riqueza hacia ciertas empresas y organizaciones? ¿Por qué no se deja actuar al mercado y debe intervenir el Estado en favor de ésta o aquella empresa o sector? Ya se ha comentado en la segunda parte del libro 
cuándo y por qué debe actuar el Estado en la economía. En la mayoría de los casos, la teoría económica no justifica las ayudas del Estado a las empresas. La teoría económica justifica otras actuaciones diferentes que por desgracia no se implementan. Además, estas ayudas también son muy opacas, en el sentido de que es prácticamente imposible conocer a ciencia cierta el dinero que reciben las empresas, asociaciones, partidos políticos etc. de las arcas públicas, directa o indirectamente. Actualmente se está repartiendo un dinero proveniente de la UE con el fin de dinamizar la economía, hacerla más ecológica, digital y resiliente y que tiene el atractivo nombre de NextGenerationEU. Gran parte de este dinero se destinará a subvenciones y ayudas económicas a las empresas. No se puede descartar a priori que al final todo quede en una gran redistribución de la riqueza, de los contribuyentes a las grandes empresas que, sin duda, serán las grandes beneficiarias de este programa europeo. En este sentido, da la impresión de que muchas de las actuaciones desde el Estado para luchar contra el cambio climático no dejan de ser tapaderas para ayudar a las grandes empresas nacionales (y a sus propietarios), muchas de las cuales se enfrentan a un futuro muy incierto y deben recurrir al Estado para mantenerse a flote. Es decir, de nuevo, redistribución de la riqueza, de los contribuyentes a los magnates que detentan el poder fáctico.

Finalmente, resulta muy, pero que muy llamativo que a la hora de asignar los fondos, subvenciones y ayudas varias no se descarten automáticamente las empresas que hayan sido condenadas por corrupción, evasión de impuestos, prácticas anticompetitivas o actuaciones que demuestren falta de sensibilidad social.

Pasemos ahora a comentar en qué consisten las políticas redistributivas indirectas. La política redistributiva indirecta abarca casi cualquier política de asignación de recursos, es decir, implementada por el Estado, y su efecto redistributivo puede ser más o menos sutil.

Pensemos, por ejemplo, en la política educativa. Como ya hemos visto, el que el Estado destine recursos a la política educativa se justifica por ser la educación un bien preferente, de gran importancia para fomentar la igualdad de oportunidades y por las externalidades positivas que genera. Si el Estado sufraga los gastos educativos a las familias, estará implementando una política 
redistributiva, pues de esta manera permite el acceso a la educación a personas que, de otro modo, en un caso extremo, no podrían permitírselo. Efectivamente, muchas personas solo pueden acceder a la educación porque el Estado sufraga esos gastos. Solo gracias a esa redistribución de la riqueza. ¿Cuántas personas pueden pagar un colegio privado?. Pensemos en el caso de los estudios universitarios. En algunos países son gratuitos o tienen un coste muy bajo. En otros, la política redistributiva para facilitar el acceso a los estudios superiores se realiza mediante becas. Y, en otros, como en EEUU, no hay ayudas del Estado. En esta situación, millones de personas se han visto obligadas a endeudarse para poder asistir a la universidad, lo que en muchos casos se convierte en un verdadero drama personal si no se puede devolver el préstamo debido a los bajos salarios que se perciben, a pesar de la educación recibida, por ejemplo, a causa de las crisis económicas.

Veamos otro ejemplo, la sanidad. Sabemos que la intervención del Estado en la sanidad está justificada por diversos motivos. Así, las imperfecciones del mercado sanitario fomentan la selección inversa, es decir, solo querrían tener un seguro sanitario las personas que saben que van a enfermar, mientras que las sanas no querrían un seguro, siendo la postura de las empresas aseguradoras justamente la opuesta. La salud de la población, como vimos, genera muchas externalidades positivas. Además, siendo que muchas personas no pueden hacer frente a los gastos médicos y el impacto que tiene la salud en otros ámbitos, como el laboral, la intervención del Estado aumenta la igualdad de oportunidades. En esta línea de pensamiento, el Estado realiza también una función redistributiva, destinando recursos a sufragar los gastos sanitarios de gran parte de la población que, de otro modo, no tendría acceso a los cuidados médicos. Muchas personas opinan que es de justicia redistributiva que la sociedad atienda a los enfermos y accidentados. Pero ésta no tiene por qué ser la opinión imperante. Es el caso, por ejemplo, de los EEUU, donde, ante la falta de actuación del Estado, y debido a un sistema increíblemente ineficiente que beneficia a las empresas sanitarias privadas, muchas personas viven al margen del sistema sanitario porque no se lo pueden permitir.

Son muchas las actuaciones del Estado que suponen una redistribución de recursos, prácticamente todas. Por ejemplo, la política de vivienda, la de 
protección de medioambiente, fomento de la cultura y el deporte, la creación de infraestructuras...En todos los casos, el Estado ha detraído dinero de los contribuyentes y decide gastarlo en un ámbito concreto, beneficiando a sujetos y empresas particulares, lo que supone una redistribución de la riqueza, si bien el objetivo principal de esa política no sea necesariamente la redistribución. Por esta razón, es usual que en la definición de estas políticas no se tenga en cuenta su potencial de redistribución de la riqueza, lo que, desde mi punto de vista, es un error. Pensemos, por ejemplo, en las inversiones y el empleo público. Son dos partidas de gasto muy importantes con un enorme efecto redistributivo en términos sociales y geográficos y que, en España no se considera en absoluto. Por ejemplo, el que el Estado gaste dinero en contratar a empleados públicos no deja de ser una forma de redistribución de la riqueza, con independencia de que, lógicamente, estos empleados públicos realicen sus funciones. Y no es lo mismo que el Estado contrate mayoritariamente a personal investigador que a personal mucho menos cualificados. Estas decisiones tienen también una vertiente redistributiva y, por supuesto, mandan señales al mercado de trabajo que inciden en el nivel de formación de la población activa.

Además, no es lo mismo que estos empleados estén trabajando en Madrid o en Soria a efectos de redistribución geográfica. Por ejemplo, se puede luchar contra la despoblación de ciertas partes del territorio ubicando en esos lugares agencias y organismos estatales, museos estatales etc., que, además del efecto directo sobre la renta local, dinamizarían la economía. Con los medios de comunicación actuales, es perfectamente posible sin pérdida de eficiencia.

Por otro lado, al igual que hemos comentado al hablar de las políticas redistributivas directas, también existen políticas que indirectamente suponen una redistribución de la riqueza encubierta inconfesable. Baste mencionar actuaciones como la creación de "chiringuitos" u organismos públicos vacíos de funciones reales cuya única finalidad cierta es garantizar un elevado sueldo público a amigos y afines, o políticas relacionadas con pelotazos urbanísticos (especulación inmobiliaria) o saqueo de bienes públicos o construcción de infraestructuras inútiles con enorme sobrecoste, envueltos en casos de corrupción muchas veces. A otro nivel, la privatización de empresas públicas también supone una redistribución de la riqueza, donde una empresa solvente, con beneficios garantizados y en un mercado estratégico y cuasi-monopolístico 
pasa a manos privadas a cambio de cantidades ridículas de dinero. Huelga decir que la teoría económica que hemos visto en la segunda parte del libro no avala este tipo de actuaciones (chiringuitos, sobrecostes injustificados y privatizaciones de empresas en ausencia de competencia real) y que los argumentos que se esgrimen para defenderlas no soportan un análisis crítico.

Resumiendo, las políticas de redistribución mediante el gasto implican necesariamente un componente subjetivo y discrecional, pues consisten en decidir a quién se le asignan recursos económicos (a quién se le da dinero) que previamente se han detraído de la colectividad mediante los impuestos. Para minimizar esa subjetividad es necesario definir qué objetivo se persigue con cada política de redistribución, qué concepción de la sociedad avala ese objetivo y si las acciones implementadas son la mejor manera de alcanzarlo, buscando siempre la simplicidad, la transparencia y el control ciudadano. También se debe considerar que todas las políticas de asignación de recursos implican, indirectamente, redistribución de los mismos.

En muchos Estados, como los pertenecientes a la UE, las políticas redistributivas directas e indirectas tienen una enorme importancia y afectan positivamente a gran parte de la sociedad. Estas políticas implican un gran porcentaje del gasto público total y benefician a muchos ciudadanos, si bien el ingreso monetario directo per cápita es reducido.

No obstante, las políticas redistributivas no siempre implican coger el dinero de los más ricos y dárselo a los pobres. En muchas ocasiones el dinero aportado por los contribuyentes se entrega mediante subvenciones y otros mecanismos a empresas, grupos de presión y amigos, de forma más o menos descarada. Curiosamente, en no pocas ocasiones, los beneficiarios de este tipo de redistribución abogan por eliminar o reducir el gasto destinado a las otras medidas redistributivas (pensiones, prestación por desempleo, ayudas a la dependencia etc.) aduciendo que suponen un gasto inasumible por el Estado y son origen de ineficiencias. Hay que tener en cuenta que pequeñas reducciones en el gasto per cápita de estas medidas liberaría fondos que se podrían destinar a otros menesteres, como subvenciones y rescates empresariales que benefician directamente a personas muy concretas. 
Para terminar, repetir una vez más que la concentración de poder económico hace que sea posible presionar al Estado para influir en sus políticas redistributivas en favor del mantenimiento de statu quo y también permite influir en la opinión pública para que vea estas actuaciones, contrarias a los intereses de la mayoría de ciudadanos, como muestra de buena gestión pública.

\subsubsection{LA RENTA BÁSICA VITAL}

No querría terminar este capítulo dedicado a las políticas redistributivas sin mencionar, aunque sea brevemente, la renta básica vital. Al lector interesado le recomiendo el libro de Juan Torres, "La renta básica". Vamos a comentar qué es, quiénes han defendido la instauración de una renta básica, qué efectos tiene, especialmente en las sociedades actuales, y cómo se podría financiar.

Existe cierta confusión en torno al concepto de "renta básica", pues existen diversas modalidades y opciones y recibe numerosos nombres, como ingreso básico universal, renta básica vital, subsidio universal incondicional... en función de si se dan o no unas características específicas. En sentido estricto, y con algunas matizaciones, la renta básica es un ingreso proporcionado por el Estado a todos los ciudadanos de forma incondicional, con independencia de que tengan otros ingresos o más o menos patrimonio, tengan o no un empleo, lo busquen o no. Todos los ciudadanos la reciben, desde el más rico al más pobre, y todos cobran la misma cantidad, aunque los menores de edad pueden recibir una cantidad menor que los adultos. La recepción de la renta es a título individual, personal, todos los meses a lo largo de toda la vida. La renta básica se percibe en dinero, aunque en algunas ocasiones se puede utilizar un impuesto negativo sobre la renta, por lo que el ingreso sería, en su caso, anual. La finalidad de la renta básica no es eliminar la pobreza (aunque puede ayudar a este objetivo), sino más bien proporcionar mayor libertad a las personas dándoles mayor seguridad económica. Para hacernos una idea, según los expertos, en la situación actual (2020), la renta básica en España podría suponer una cantidad alrededor de 600 euros mensuales. La renta básica no se plantea como sustitutivo de otras políticas sociales, pero sí que modificaría y simplificaría 
muchas de las políticas estatales, especialmente las de naturaleza redistributiva, pero no solamente éstas.

A lo largo de la historia son muchas las personas que han defendido que todas las personas debieran poder acceder a un mínimo de subsistencia, pues el ser humano no puede ser libre si no alcanza unas condiciones materiales mínimas. Así, por no retroceder a la antigua Grecia, ya Jesús de Nazaret, persona en teoría de gran predicamento entre los cristianos, si bien defendía que a cada cual se le debe exigir según su capacidad (parábola de los talentos, Mt. 20,1-16, por ejemplo), es decir, se espera que todos contribuyan a la comunidad, subrayaba que el pago no tiene por qué depender del esfuerzo realizado (parábola de los obreros en la viña Mt. 25, 14-30), de lo que se deduce que todos deberían percibir lo necesario para cubrir sus necesidades.

Se considera que el padre de la renta básica es Thomas Paine, uno de los padres fundadores de los EEUU, en el siglo XVIII. La idea de la renta básica ha sido desde entonces atacada, principalmente, por el miedo de que esa ayuda habituara al hombre a la holganza, generando perezosos que no desearían trabajar. Curiosamente, en el siglo XIX esta oposición viene tanto desde economistas conservadores (Malthus, Ricardo) como comunistas (Rosa Luxemburgo). Sin embargo, y también curiosamente, a lo largo del siglo XX también economistas de todo el espectro político han defendido alguna variante de la renta básica, desde Hayek y Friedman (padres de la escuela neoliberal y monetarista) hasta Tobin y Samuelson (de la escuela keynesiana). Incluso el presidente republicano estadounidense Richard Nixon estuvo a punto de crear un programa de ingresos garantizados mediante un tipo de impuesto negativo sobre la renta, si bien no era de carácter incondicional. Se trata, por tanto, de una problemática controvertida en la que, no obstante, están de acuerdo figuras señeras del mundo de la economía incluso con concepciones políticas diametralmente opuestas.

Lo que parece evidente por poco que nos paremos a reflexionar es que la instauración de una renta básica transformaría profundamente nuestro sistema económico y social actual. Veamos algunos de los cambios que provocaría. 
La renta básica es un instrumento contra la pobreza y la exclusión social, aunque la cantidad de dinero entregado a cada persona no sea elevada. Desde los principios que se defienden en este ensayo, se trata de un aspecto muy positivo en el camino de garantizar a todos un contexto económico y social favorable para el desarrollo personal. La renta básica implicaría cambios radicales en las políticas asistenciales, ineficientes, complejas y costosas, llenas de burocracia y controles, por lo que es de esperar encontrar oposición por parte de las personas que se verían afectadas (funcionarios, asociaciones, "cazadores de subvenciones" etc.)

La renta básica implica modificar absolutamente las relaciones laborales, el concepto de "desempleo" y las políticas asistenciales. Al dar más poder negociador a los empleados, se podrían relajar los controles estatales y la burocracia y falta de flexibilidad en los contratos laborales asociada. Al disponer de la renta básica permanentemente, los trabajadores pueden rechazar o abandonar, sin temor a quedar desamparados, puestos de trabajo con malas condiciones laborales. Además, se podrían eliminar los subsidios por desempleo, al menos en su forma actual. Este mayor poder de negociación de los trabajadores, esta libertad adicional para rechazar ofertas de empleo, es probable que elimine los "trabajos basura", no tanto en el sentido de baja retribución, sino en cuanto al número de horas requeridas y condiciones de trabajo denigrantes, por lo que la renta básica cosechará la oposición de los empleadores explotadores, quienes se valen del miedo al desempleo como medida de presión para fijar condiciones de trabajo en ocasiones humillantes y degradantes.

Debemos ser conscientes de que, en la actualidad, disponer de un trabajo no garantiza disponer de suficientes recursos para llevar una vida digna. Son muchas las personas con empleo que viven por debajo del umbral de la pobreza. En EEUU, por ejemplo, muchos millones de trabajadores sobreviven gracias a los cupones de comida que les da el Estado. En este sentido, con una renta básica, esos trabajadores podrían seguir desempeñando puestos de trabajo con poca productividad aunque impliquen retribuciones bajas puesto que la renta básica servirá de complemento a su salario, sin depender de los cupones estatales y con mayor calidad de vida. También incentivaría el trabajo a tiempo parcial. Esta evolución, si bien tiene su aspecto positivo, es vista como una 
amenaza por los sindicatos, quienes piensan que será empleada por los empresarios para presionar los salarios a la baja aún más.

Otro de los efectos importantes de la renta básica es que fomentará el emprendimiento. Efectivamente, la mayor seguridad económica impulsará a muchos empleados y a parte de la población inactiva a poner en marcha diversas actividades empresariales, pues el beneficio económico obtenido se sumará a la renta básica, de forma que el beneficio mínimo exigido a los pequeños negocios disminuirá. Este hecho puede ser un impulsor de la economía colaborativa y muchas personas podrán dedicarse a actividades altruistas que no proporcionan ingresos elevados pero sí un gran sentimiento de realización personal y felicidad, lo que, además, mejorará la eficiencia de los mercados gracias a las externalidades positivas que se producen.

Para no extendernos más, finalizaremos subrayando el papel de la renta básica como protector de las personas más indefensas y desfavorecidas de la sociedad. Por ejemplo, en el caso de las mujeres, quienes lo tienen más difícil en el mercado laboral por diversos motivos, les permite aumentar su autonomía económica, lo que incide positivamente en situaciones como la violencia de género o el divorcio, por no hablar de la lacra de la prostitución y otros usos mercantiles del cuerpo femenino a los que empuja la miseria. Todo esto supone una inmensa mejora en términos de bienestar físico y psicológico para millones de personas. Pero, una vez más, es fácil detectar quiénes se verán perjudicados y, por lo tanto, se opondrán a la implantación de la renta básica.

Desde una perspectiva crítica, algunas personas opinan que muchos trabajadores dejarán sus puestos de trabajo para vivir exclusivamente de la renta básica. Esto es perfectamente posible, pero lo más probable es que se trate de trabajadores en situación muy precaria que están siendo explotados por sus empleadores. No creo yo que ningún notario, médico, bombero o profesor deje definitivamente su trabajo por una renta básica que, no olvidemos, cobrará igualmente, trabaje o no, como si fuera un simple complemento. ¿Dejaría el lector su puesto de trabajo indefinidamente? En caso afirmativo, ¿es feliz en su trabajo o será más feliz sin ir a ese trabajo? ¿Renunciará para siempre a la búsqueda de otro trabajo? Cuando se plantea la renta básica como un simple complemento y se pregunta: “¿Qué le parecería a usted cobrar 600 euros más 
al mes?", la respuesta suele ser afirmativa. No obstante, al explicar que sería un complemento para todo el mundo, surgen los problemas. Obviamente, nosotros seremos capaces de gastar correctamente ese suplemento económico pero, inmediatamente, nos vienen a la mente colectivos que seguro que despilfarran ese dinero y no lo emplean como es debido, por lo que no son dignos de él. Curiosamente, esos colectivos suelen ser de un estrato social bajo, pertenecen a grupos marginados. Es decir, los pobres, los más necesitados, no saben gastar el dinero adecuadamente y lo derrochan en vicios. Y nunca nos viene a la mente la imagen de un rico derrochando el dinero alegremente y, si es el caso, nos parece bien. ¿Cuestión de manipulación? Sea como fuere, el caso es que habría que preguntarse si merece la pena bloquear una medida que produce tantos cambios positivos en tantos millones de personas solo con el fin de que unos pocos no puedan tener la libertad de emplearla de forma, a nuestro parecer subjetivo, errónea. Por otro lado, esas personas a las que consideramos poco merecedoras de recibir ayuda pública es posible que ingresen más dinero con el sistema asistencial actual.

La otra gran pregunta relativa a la implantación de una renta básica es el origen de la financiación de tal medida. ¿De dónde sale el dinero? Es también curioso que no nos preocupe esta cuestión cuando se trata de otras políticas, pero sí en el caso de la renta básica. Sin entrar en mayor detalle, las fuentes de financiación posibles son numerosas: el impuesto sobre la renta de las personas físicas, impuestos a las rentas del capital, impuestos al patrimonio, impuesto a las transacciones financieras, ahorro en otras partidas del gasto, expansión monetaria mediante la creación de criptomonedas oficiales... Es decir, haberlas, haylas. Probablemente se recurra un poco a cada una de las opciones. También es posible que en algunos casos se aplique como un impuesto negativo sobre la renta, que exige un menor desembolso por parte del Estado.

La financiación de la renta básica no es en realidad el principal problema. Pero, lógicamente, se trata de una política redistributiva que se ganará la enemistad de los que tengan que aportar más para sufragarla. Además, y esto también es importante, al consumir un porcentaje elevado del presupuesto público, limitará la discrecionalidad en el gasto por parte de los políticos, es decir, tendrán menos dinero sobre el que decidir cómo debe gastarse. 
La creación de inflación tampoco tiene por qué ser un problema. La inflación, como hemos comentado, depende de numerosos factores y es difícil realizar predicciones. En cualquier caso, en la situación de deflación actual, muy lejos del objetivo del BCE, la inflación no debería ser percibida como un problema si conlleva las ventajas que hemos comentado.

El verdadero enemigo de la renta básica es que se trata de un verdadero cambio de paradigma, cuando el empleo remunerado deja de ser el centro de la sociedad.

Actualmente, el empleo es el eje fundamental de nuestra sociedad. Hemos comentado más arriba cómo la riqueza que se genera se reparte entre capitalistas y trabajadores y después, el Estado actúa para redistribuir la riqueza. Ahora bien, ¿qué pasará en una sociedad en la que gran parte del trabajo lo realicen las máquinas, los robots? El trabajo ya no servirá como medio para repartir la riqueza que se produce y los capitalistas acapararán toda la plusvalía. Como consecuencia, la desigualdad social aumentará vertiginosamente, creciendo de forma dramática el número de personas en situación de pobreza y desapareciendo la clase media. Para que haya graves cambios sociales, no es necesario que se elimine todo el empleo. Basta con que aumenten un poco las masas de desempleados y se les recorten las ayudas para generar malestar social. Además, la falta de recursos de los desempleados y sus familias reducirá su consumo a lo indispensable, lo que afectará a la demanda agregada y a la economía en su conjunto. En los países europeos se verán afectados los sistemas de pensiones. Y, desde luego, los ingresos del Estado, que se nutren principalmente de las rentas generadas por los trabajadores y su consumo.

Es posible que el lector piense que este panorama oscuro es exagerado. Yo no me atrevo a profetizar nada. Pero, desde luego, la situación futura es tremendamente incierta. Lo cierto es que los robots pueden realizar cada vez más trabajos, desde mover mercancías en almacenes o conducir camiones y automóviles, hasta ordeñar vacas, responder llamadas de teléfono, componer música y gestionar restaurantes. Millones de puestos de trabajo de todo tipo peligran en la medida en que avanza la tecnología, los robots adquieren más capacidades y son más baratos. En un primer momento es posible que el Estado actúe protegiendo a los trabajadores y prohíba el uso de robots, por ejemplo el 
uso de vehículos autónomos. Pero esta medida, que no tiene mucho sentido desde el punto de vista de la eficiencia económica, no durará mucho. Lo único que puede frenar esta evolución es la carestía de las materias primas necesarias para la producción de microchips o una crisis energética por agotamiento de combustibles fósiles.

Lo que está fuera de toda duda es que, en un futuro muy cercano va a haber un cambio de paradigma económico y social que va a alterar desde sus cimientos, entre otras muchas cosas, la generación y la distribución de la riqueza y el papel que realiza el Estado en la economía. Y el cambio no tiene por qué ser necesariamente a mejor. Dependerá de cómo se movilice la sociedad para defender sus libertades y derechos adquiridos. 


\section{ASIGNACIÓN DE RECURSOS}

La tercera área de intervención estatal en la economía, junto la estabilización económica y la redistribución de la renta, es la asignación de recursos. Se trata de un área de actuación muy amplia que consiste, básicamente, en influir en cómo se asignan los recursos económicos (mano de obra, recursos naturales, capital) a la producción de bienes y servicios determinados. Así, debido a la intervención del Estado, se producirá más de un bien y menos de otro. Se ofrecerá un servicio y se dejará de ofrecer otro.

En el ámbito de la política estatal de asignación de recursos, al igual que en las otras áreas de intervención estatal, lo primero que hay que cuestionarse es la necesidad de la actuación del Estado. Y, al igual que en los casos anteriores, esta justificación la encontramos en los fallos de los mercados. La existencia de fallos en los mercados de competencia perfecta, así como la existencia de mercados imperfectos justifican que el Estado intervenga para mejorar la eficiencia y la distribución de la riqueza.

A lo largo de la historia el papel del Estado en la economía se ha ido modificando conforme evolucionaba la sociedad, la tecnología y la actividad económica. En algunas épocas y bajo determinados sistemas de gobierno y económicos el Estado ejercía un control enorme sobre la actividad económica. En otras épocas, la situación ha sido la inversa. En Europa, en el siglo XX, hemos experimentado la economía de guerra, el sistema capitalista de libre mercado, el comunismo, y el sistema de economía mixta. En la actualidad, el sistema económico europeo tiene características neomercantilistas muy significativas, mientras que en China impera el capitalismo de Estado con una economía en parte planificada y en parte con mercado. No es posible encontrar economías reales que se adapten perfectamente a los modelos o clasificaciones económicas. Lo que observamos es que, actualmente, se busca un equilibrio entre la actuación de los mercados y la actuación planificada del Estado en la asignación de los recursos económicos. 
El Estado puede influir en la asignación de los recursos básicamente por dos vías: la extrapresupuestaria, esto es, mediante la regulación, y la presupuestaria, es decir, utilizando dinero público para participar, directa o indirectamente, en la producción de bienes y servicios. En las economías actuales, en las que el Estado interviene activamente en numerosos sectores económicos, los ejemplos de este tipo de política estatal son numerosísimos. En el ámbito de las actuaciones extrapresupuestarias el Estado puede, por ejemplo, prohibir la construcción de macrogranjas contaminantes, la entrada en las ciudades de vehículos privados, la construcción de hoteles en parques naturales o puede controlar el precio del alquiler de viviendas. En cuanto a las actuaciones que conllevan asignaciones presupuestarias relevantes, podemos nombrar los rescates a empresas, la obra pública en infraestructuras, subvenciones a empresas, la creación de empresas que pertenecen al Estado o la nacionalización de empresas privadas, el sistema educativo público o el sistema sanitario público etc.

Como vemos, son muchos los ámbitos de actuación del Estado en la producción de bienes y servicios. Basta pensar en el nombre de los numerosos ministerios estatales, las consejerías autonómicas y las concejalías locales, y observaremos que muchos de ellos se dedican a regular y controlar la actividad económica o a participar directamente en ella: educación, sanidad, cultura, radio y televisión, agricultura y pesca, minería, industria, universidades, investigación y ciencia, consumo, cultura y deporte, transportes... Cuando las actuaciones implican la producción de bienes o la prestación de servicios, el Estado puede intervenir directamente en la producción o puede hacerlo a través de empresas privadas. Esto es muy importante recordarlo. El hecho de que exista una justificación para que el Estado intervenga en la economía no determina cómo debe el Estado implementar esa actuación. Por ejemplo, el Estado puede construir directamente las carreteras o puede contratar la construcción con empresas privadas o puede usar un sistema de concesión. Puede garantizar la asistencia sanitaria gratuita a través de un sistema sanitario público o mediante un sistema de compañías de seguros privados. O puede fomentar el avance científico creando institutos de investigación estatales o subvencionando la investigación a las empresas privadas. A priori, sobre el papel, ninguna de las opciones es mejor. Podemos 
encontrar argumentos razonables a favor y en contra de cualquier opción. La clave está, en mi opinión, en el control que se pueda ejercer sobre ellas en términos de control del gasto, control de la eficiencia, flexibilidad que permita realizar cambios en el futuro y existencia de competencia.

A continuación vamos a profundizar en algunos de estos aspectos. En primer lugar repasaremos algunos casos que justifican la intervención estatal y los problemas que implica el diseño de políticas de asignación del gasto. Seguidamente nos centraremos en la denominada "política industrial" estatal, y, especialmente, en el sector público empresarial, analizando la conveniencia o no de que el Estado cree sus propias empresas y organismos para producir bienes y servicios. Esta política está sujeta a numerosas controversias y ha sufrido fuertes vaivenes desde la Segunda Guerra Mundial. Para concluir este capítulo, haré unas reflexiones sobre los retos a los que se enfrenta la sociedad en estos momentos, por qué la correcta actuación estatal en la producción de bienes y servicios es decisiva y por qué nos enfrentamos a un cambio de paradigma.

\subsection{LA INTERVENCIÓN DEL ESTADO}

Recordemos una vez más que estamos defendiendo que la actuación del Estado en la economía se justifica en la necesidad de crear y sostener un entorno social y económico que permita que los ciudadanos desarrollen libremente su personalidad con dignidad y se respeten los derechos humanos, de forma que los ciudadanos podamos ser plenamente responsables de nuestra existencia y nuestra búsqueda de la felicidad, una vez cubiertos unos mínimos materiales y psicológicos. En este contexto, las personas necesitamos de una serie de bienes y servicios que van cambiando conforme avanza la tecnología y evoluciona la sociedad. Por ejemplo, según el art. 25.1 de la Declaración Universal de los Derechos Humanos, toda persona tiene derecho a alimentación, vestido vivienda, asistencia médica y los servicios sociales necesarios. Estas necesidades han existido desde siempre. El cómo se satisfacen estas 
necesidades depende de la sociedad en la que vivimos y la tecnología disponible.

Por ejemplo, en un sistema comunista, es el Estado el que toma todas las decisiones relacionadas con la producción: qué producir, cuánto producir, cómo producir. En un sistema de libre mercado capitalista puro, por el contrario, el Estado no interviene en absoluto y estas decisiones competen a la empresa privada exclusivamente. Entre ambas alternativas existen numerosas opciones, como la economía mixta o el capitalismo de Estado, en las que unas decisiones se toman por la empresa privada y otras por el Estado. Por lo general, el objetivo ha sido siempre aumentar la producción, de forma que la bondad de un sistema frente a otro se valora comparando el crecimiento económico que produce.

Actualmente, muchos pensamos que la intervención del Estado es imprescindible para asignar los recursos de forma eficiente y alcanzar ciertos objetivos de equidad. Ya hemos comentado en este libro los fallos del mercado de competencia perfecta, lo difícil que es que se cumplan todas las hipótesis que exige el modelo y cómo existen mercados imperfectos que causan ineficiencias. La intervención del Estado debe estar siempre justificada y debe restringirse a la mínima expresión posible y siempre para corregir los fallos del mercado o actuar cuando no hay un mercado. Si no se cumple esta condición, es muy probable que la actuación estatal sea más ineficiente que la actuación privada.

Veamos algunos casos en los que la actuación estatal está justificada, cómo puede actuar y cómo esta actuación modifica la asignación de recursos que se hubiera hecho en una economía sin intervención estatal.

Las externalidades negativas como la contaminación son un claro ejemplo de justificación de la actuación del Estado. Éste puede tomar diferentes medidas regulatorias para reducir la contaminación, como la prohibición de realizar vertidos en los ríos, la obligación de instalar filtros que eviten la emisión de ciertas partículas a la atmósfera, impuestos que gravan la contaminación, o la creación de mercados como el de emisiones de CO2. La intervención del Estado hace que la producción del bien que ocasiona la contaminación sea más cara, por lo que será menos rentable y se producirá menos. Además, es un aliciente para la innovación tecnológica, pues los fabricantes buscarán formas de producir que no 
contaminen o productos sustitutivos no contaminantes. A medio plazo es esta innovación tecnológica la que permite acabar con el proceso productivo contaminante. Vemos que la actuación del Estado, efectivamente, afecta a la asignación de recursos.

Otro ejemplo son los bienes preferentes, aquellos que son necesarios para poder disfrutar de una vida digna o que generan externalidades positivas de las que se beneficia toda la sociedad. Sin la intervención del Estado, la producción de estos bienes sería inferior al nivel de producción eficiente. Ejemplos de bienes preferentes son la sanidad y la educación.

En países en los que no interviene el Estado, muchas personas no pueden acceder a los servicios sanitarios privados por falta de medios económicos, lo que ocasiona graves perjuicios a esta población y a la economía en su conjunto. En estos casos, la producción del servicio "salud" es inferior a la demanda de la población. El Estado debe corregir esta ineficiencia si quiere cumplir con su objetivo de garantizar una existencia digna a los ciudadanos. La intervención puede ser extrapresupuestaria pero es, muy especialmente, de carácter presupuestario. El Estado debe destinar grandes cantidades de dinero a proteger a los ciudadanos de una eventual enfermedad o un accidente. Son sucesos aleatorios que pueden sucederle a cualquier persona y, conforme se avanza en edad, más probable es la necesidad de atención sanitaria. En muchos Estados europeos la atención sanitaria pública es gratuita. Esto no significa que la preste el Estado necesariamente. El Estado puede tener sus propios ambulatorios, hospitales y personal sanitario, pero también puede subcontratar estos servicios con empresas sanitarias privadas y empresas aseguradoras. Ambos sistemas pueden garantizar el acceso a la sanidad de toda la población. ¿Qué sistema es mejor? Como ya hemos comentado, dependerá de cómo se gestione cada opción. A su vez, esto depende del control que se pueda ejercer sobre los gestores públicos y la transparencia de los contratos entre el Estado y la empresa privada.

La educación es un bien que influye decisivamente en las opciones de desarrollo personal y profesional y que, además, genera grandes externalidades positivas. Por otro lado, en muchos países es común que los padres no dejen que sus vástagos, especialmente las niñas, vayan a la escuela más de unos pocos años 
y los ponen a trabajar. Por otro lado, el sector privado tampoco generará suficientes plazas como para escolarizar a toda la población y quedarían fuera del sistema educativo las personas con menos recursos, que estarán condenadas al analfabetismo, con las implicaciones sociales y laborales correspondientes. Sin la intervención del Estado, se produce un sistema educativo ineficiente que excluye a la población más desfavorecida. Una vez más, la intervención del Estado puede materializarse de diversos modos. En muchos países existe, junto a la enseñanza completamente privada, la enseñanza pública gratuita, de la que se encarga el Estado. La convivencia de ambos sistemas es positiva en términos de libertad de elección y también como fuente de competencia e información, pues el sector público puede comparar su eficiencia con el sector privado. En España, además, existe la enseñanza concertada, en la que colegios privados sujetos a una serie de condiciones ofrecen sus servicios gratuitamente a los alumnos y son remunerados por el Estado. Como venimos defendiendo, todas las opciones de intervención pueden ser positivas siempre y cuando exista el control necesario. Así, en el caso de la escuela concertada, uno de los requisitos fundamentales es que estén en igualdad de condiciones con la escuela pública, por ejemplo, en términos de financiación o a la hora de seleccionar los alumnos.

Más adelante, cuando tratemos de la política industrial, trataremos otros fallos del mercado que justifican la intervención del Estado en la asignación de recursos, como la existencia de monopolios naturales o la falta de información.

\subsection{DIFICULTADES EN EL DISEÑO DE POLÍTICAS DE ASIGNACIÓN DE GASTO}

Actualmente, en países como España, la actuación del Estado mediante políticas de asignación de recursos es muy amplia y, ciertamente, está muy encasillada. Realmente hay pocas posibilidades de realizar grandes cambios y las diferentes y numerosas políticas son completamente autónomas unas de otras, sin que exista una verdadera coordinación. Efectivamente, hay una gran inercia en la 
actuación del Estado, que lleva ya muchos años interviniendo en la economía. La situación actual es el resultado de una evolución histórica y es difícil modificarla. Cuando se quieren realizar cambios, se modifican levemente las políticas existentes, se añaden otras, pero solo excepcionalmente se recortan y eliminan políticas obsoletas. Como veremos en el próximo capítulo, esto se debe a la existencia de grupos de presión o agentes económicos, como la propia burocracia estatal, que influyen en la actuación del Estado y provocan que su funcionamiento sea ineficiente, inflexible y despilfarrador. Por este motivo, las nuevas políticas se basan necesariamente en las anteriores, los presupuestos de cada política de gasto no difieren sustancialmente de un año a otro, salvo contadas excepciones y no se implementa un presupuesto de base cero, ni se examina en profundidad la eficacia de las actuaciones públicas.

¿Qué pasaría si hacemos un ejercicio de imaginación y diseñamos las políticas ex novo, desde cero, pensando en primer lugar en las necesidades de las personas, en mejorar su calidad de vida?

Lo primero que se debe definir siempre es el objetivo de la intervención estatal. Para nosotros, el objetivo primordial, el marco de referencia, es el bienestar de las personas. Y no solo de las personas adultas, también los niños y bebés. Por lo tanto, puede ser interesante analizar cómo la actuación del Estado influye en el contexto vital de los bebés y cómo se podría mejorar. Vamos a ver que las conclusiones de este pequeño ejercicio mental son bastante reveladoras.

La intervención del Estado en la economía influye en las personas incluso antes de que éstas nazcan. Por ejemplo, los padres tendrán a sus hijos a una edad o a otra dependiendo de factores controlados por el Estado, desde la educación sexual impartida en los colegios, hasta las opciones de planificación familiar, pasando por la facilidad de encontrar un empleo, tener una vivienda (en propiedad o alquilada) e independizarse. Por este motivo, el que se considere que es conveniente tener el primer hijo a los 14 años o a los 40 años requiere ya una actuación del Estado en un sentido o en otro.

Si nos centramos en la problemática de dejar el "nido" e independizarse, nos encontramos con una serie de problemas que hay que identificar. De hecho, la pregunta es: ¿cuál es el verdadero problema? Tradicionalmente, el problema 
que se identifica es la falta de un empleo, de un trabajo remunerado. Este empleo garantiza un salario con el que se puede alquilar o tal vez adquirir una vivienda y permite comprar los bienes necesarios para la vida, incluso ahorrar para sufragar imprevistos. Por este motivo, el enfoque para abordar el problema es el de la creación de empleo. Actualmente, al menos en España, nos encontramos con que el empleo juvenil es escaso y precario, es decir, inestable y mal pagado, insuficiente para independizarse. Las políticas estatales van encaminadas a intervenir en el muy ineficiente mercado laboral mediante medidas varias como la creación de un salario mínimo interprofesional (como existe en España o en EEUU), diferentes tipos de contratos para incentivar la contratación de jóvenes, programas de formación y otras medidas muy onerosas y poco efectivas.

Pero, tal vez, el problema que afecta a los jóvenes pudiera afrontarse mejor cambiando el enfoque y dotándoles con una renta básica vital que les garantizara ingresos y una política de vivienda pública, que afectaría al también ineficiente mercado de la vivienda. Una renta básica que, además, afectaría positivamente a otras muchas políticas públicas.

El proceso del embarazo, fundamental para el futuro desarrollo de la persona, y el parto merecerían sendos capítulos. Si pensamos, como se dice siempre, que los niños son el futuro y lo que más quieren los padres (todo lo cual es bastante cierto), tal vez se debieran modificar algunas situaciones laborales y ciertas actuaciones, protocolos e infraestructuras sanitarias, por el bienestar del recién nacido y la madre. En este caso, como en todos los demás, es fundamental ver qué se hace en otros países.

A los pocos días, el recién nacido entra ya en contacto con la Administración Pública y en algunos países comienza un periplo burocrático de relación con la Administración Pública que durará hasta después de la muerte. En muchos casos los procesos administrativos son obsoletos y exigen, sin ninguna necesidad real, la participación del ciudadano a pesar de que la Administración ya dispone de toda la información que solicita. Por eso, en aras de la eficiencia, es imprescindible que se instaure una verdadera administración electrónica, en la que los diferentes órganos administrativos estén conectados y puedan solicitarse información, salvo que el administrado haga constar expresamente su 
disconformidad. Ya solo el inmenso ahorro en tiempo que se lograría hace que esta medida merezca la pena.

El principal problema que deben afrontar los padres en los meses des pues del parto es la crianza del bebé. Y aquí el papel del Estado en la economía vuelve a ser crítico. Siendo como somos mamíferos, existe un fuerte apego entre el bebé y la madre, y no solo por el hecho de mamar. Además, el ser humano no es como los otros mamíferos, que se pueden valer por sí mismos a las pocas horas. Por razones evolutivas, el ser humano nace cuando aún le falta mucho para alcanzar una mínima independencia, está completamente indefenso y necesitado de cuidados continuos. Por esta razón, parece que lo más adecuado para la salud del bebé (y para la salud, al menos psicológica, de los padres), es que los progenitores puedan estar siempre con él durante los primeros meses, muy especialmente la madre. Pero si ambos progenitores trabajan, la situación puede ser complicada. En este contexto, la intervención del Estado puede ser nula, puede focalizarse en el bienestar del bebé y de los padres o puede centrarse en intervenir en el mercado laboral intentando garantizar unos derechos a los padres.

Cada Estado aborda el problema con un enfoque diferente. En EEUU la baja por maternidad no existe y son los padres los que asumen todos los costes de tener y criar a los hijos. En otros países el periodo de la baja se cuenta en semanas, y en otros en meses. En unos países se puede solicitar una excedencia, en otros te pueden despedir. Todas estas opciones tienen a su vez un impacto en la calidad de vida de las personas implicadas y en la sociedad.

La regulación del mercado laboral es determinante en el cuidado de los bebés. Por desgracia, en muchas ocasiones no se legisla pensando en el bienestar del bebé, sino en cuál será la reacción de los empresarios y los votantes ante la nueva legislación. Obviamente, no debe ser el empresario el que se vea afectado negativamente por el nacimiento de un bebé y debe ser el Estado, la sociedad, quien sufrague los costes. En cualquier caso, el empleador se verá afectado, pues pierde a una empleada que estará de baja durante algún tiempo y deberá formar a su sustituto. Además, si las bajas son de varios meses, con posibilidad de excedencias y la mujer tiene varios hijos, cuando regrese a su puesto de trabajo es posible que la mujer deba volver a formarse para desempeñar su 
trabajo correctamente. También la persona que haya sustituido a la mujer se verá afectada por su regreso al mundo laboral, pues verá peligrar su puesto de trabajo. Y, obviamente, la carrera laboral de la mujer que dedica varios años de su vida a la crianza de los hijos se verá afectada. Y es que, en muchas ocasiones, ser madre se juzga por las empresas como un hándicap, un demérito, cuando tal vez debiera ser todo lo contrario. Ante esta situación, el Estado actúa a veces para evitar que el mercado laboral penalice a las mujeres, por ejemplo, otorgando a los hombres las mismas semanas de baja de paternidad que las que disfrutan las mujeres por maternidad. Se trata también de conseguir que las mujeres se puedan reincorporar a su puesto de trabajo cuanto antes, para lo cual el Estado toma medidas como promover guarderías gratuitas para bebés de cuatro meses o modificar levemente el horario laboral para poder dar de mamar. Estas medidas, bien intencionadas desde la perspectiva de la igualdad de oportunidades en el mercado laboral, tal vez no sean las más idónea si pensamos en el bienestar de las personas. $Y$ es que las consecuencias negativas de estas políticas son diversas, como bien saben los progenitores. Por no extenderme, nombraré solo el sufrimiento de los niños al verse separados de sus padres, pues el cuidado de la mejor guardería no es comparable al cuidado personalizado de una madre, la ansiedad y el agotamiento en los padres, los problemas con la lactancia, las enfermedades recurrentes en muchos bebés, que sufren, por ejemplo, recurrentes bronquiolitis, y bajas laborales para hacerse cargo de los hijos si no se cuenta con ayuda familiar.

Si ideamos una política desde cero, pensando en el bienestar del bebé como medida para juzgar la bondad de las políticas, las intervenciones del Estado cambiarían radicalmente, al menos en España. $Y$ es que, algo tan importante y bonito como la crianza de los hijos, en la actualidad se puede convertir en un foco de tensión y padecimiento insano.

El objetivo principal sería que el bebé y los padres, muy especialmente la madre, pudieran estar juntos durante al menos el primer año. Una de las ventajas de esta medida sería que facilitaría la lactancia, que, entre otras cosas vigoriza el sistema inmunológico del bebé. Evitaría el stress del niño y de los padres por la separación. Los padres estarían menos cansados y de mejor humor, lo que redundará en beneficio del bebé. Reduciría la ansiedad de la madre que en 
algunas ocasiones no puede dedicarse ni al bebé ni al trabajo lo que quisiera ni con la calidad deseada. Permitiría tener que recurrir menos a la ayuda familiar. Este objetivo principal se puede conseguir sin excesivos problemas, tal y como se hace en otros países europeos, en los que la participación de la mujer en el mundo laboral es, por lo menos, tan intensa como en España. En cualquier caso, si se desea, hay suficientes recursos para sufragar este tipo de políticas.

Otro aspecto fundamental en el que actuaría el Estado es la formación y la educación, para cambiar la forma en que la sociedad (la sociedad española, no ocurre lo mismo en otros países europeos) mira a los bebés y el proceso de crianza. Se trata de un cambio necesario en muchos casos y fundamental. Criar a un bebé es una tarea de vital importancia, en sentido literal. $Y$ es importante para el bebé y para la sociedad, pues los bebés son la sociedad del futuro. Es una tarea que debe ser muy bien valorada por la sociedad, al contrario de lo que sucede ahora en España. Además, la sociedad en su conjunto, incluyendo a los profesionales sanitarios y a los educadores, deben estar bien informados de los avances en los campos relacionados con el proceso de desarrollo de los bebés y su cuidado. Un caso paradigmático es la lactancia, pues son muchas las personas que siguen ancladas en los conocimientos de los años 70 del siglo pasado. Es básico saber qué significa realmente "criar un bebé", qué responsabilidades implica. Porque, como suele decirse, los niños no vienen con manual de instrucciones, por lo que se aprende de oídas y por la experiencia, por esta razón hay inercias que hacen que los errores pasen de generación en generación. Una correcta crianza es muy necesaria, pues es posible que algunos problemas psicológicos y de salud de los adultos tengan su origen en su infancia. $Y$ hay que tratar a los bebés y a los niños con amor y respeto. Por desgracia, el maltrato infantil (en sus muy diversas manifestaciones, no solo físicas) existe en nuestra sociedad y hablar de él es un tema tabú. El Estado debiera realizar campañas de información, concienciación y vigilancia.

Para terminar este fugaz análisis, mencionar que también es necesario, como ocurre en otros países, que se vea con normalidad que las mujeres abandonen durante un tiempo su carrera laboral para ocuparse de los hijos. Y esta pausa temporal no debiera ser un impedimento insalvable en su progresión futura, como tampoco ocurre en otros países en los que, además, la brecha salarial entre hombres y mujeres es menor. Habría que analizar, por tanto, cuál es la 
causa de esa brecha salarial. También sería interesante estudiar el impacto que tendría una renta básica, pues daría más autonomía financiera a muchas mujeres, como por ejemplo a las que prefieren tener a sus hijos antes de incorporarse al mercado laboral.

Una vez el bebé crece, el siguiente paso es la guardería. Luego el colegio. Y así se podrían ir analizando todas las políticas estatales, desde la política universitaria a las pensiones, pasando por la política de empleo o la protección del medio ambiente, viendo si cumplen el objetivo principal de mejorar la calidad de vida de las personas de la manera más directa y con la menor intervención posible. Lo que hemos tratado de mostrar es que las políticas estatales actuales, en muchos casos, aunque son bienintencionadas, pueden estar mal diseñadas por tener como objetivos lo que en realidad son medios para alcanzar el verdadero fin. En este ejemplo hemos visto cómo, para alcanzar el fin deseado, deben coordinarse diversas actuaciones estatales en el ámbito de la sanidad, la educación, la regulación laboral o las políticas redistributivas. Diseñar correctamente una política es extremadamente complejo, pues los puntos de vista acerca de lo que es "mejor" no suelen ser coincidentes. Pero tener siempre sobre la mesa el fin último que se persigue puede ayudar, al menos, a valorar la eficacia de las políticas implementadas.

\subsection{LA POLITICA INDUSTRIAL}

A la actuación del Estado para fomentar el crecimiento económico se le denomina política industrial. Esta política abarca gran variedad de actuaciones, como la creación de infraestructuras, el fomento de la investigación, los rescates de empresas privadas con dinero público, subvenciones a empresas, exenciones fiscales, política arancelaria, financiación a empresas, concesiones, creación de clústeres empresariales, desarrollo del sector público empresarial, legislación sobre patentes y propiedad intelectual, medidas para fomentar la competencia y otras muchas. 
A continuación comentaré brevemente algunos ejemplos de estas actuaciones de política industrial. Como en otros casos, la justificación de la actuación del Estado viene avalada por la existencia de fallos en los mercados, pero veremos que el Estado tiende a extralimitarse y a actuar cuando no es necesario o a hacerlo de forma ineficiente, movido en muchas ocasiones por los grupos de presión.

Uno de los argumentos que justifica la actuación del Estado es la protección de la industria naciente. Estas industrias generan externalidades positivas, como la creación de nuevos mercados o nuevos conocimientos no patentables, cuyos costes asumen ellas pero benefician a todos, incluidos a los competidores extranjeros. Para compensar a las empresas por ese coste, el Estado impone aranceles y otras barreras que protegen a la industria de la competencia exterior hasta que alcance su madurez y pueda desarrollar ventajas competitivas. Uno de los problemas que conlleva este tipo de políticas que, en realidad, reducen la competencia, es identificar correctamente las industrias nacientes y cuándo éstas alcanzan la madurez. Aunque esta política suele ser muy atacada por los defensores del libre comercio, es interesante recordar que todas las grandes economías mundiales (EEUU, China, Japón, Alemania) protegieron y protegen sus industrias de la competencia internacional mediante barreras al comercio y otros instrumentos. Además, los mercados internacionales no son, ni mucho menos, mercados de competencia perfecta y abrir las fronteras implica que las empresas nacionales tienen que lugar contra grandes monopolios extranjeros que las fagocitarán en poco tiempo, lo cual no fomenta la creación de un mercado de competencia perfecta en el país.

Otra política dirigida a fomentar el crecimiento económico y el desarrollo industrial es el fomento de la investigación básica y aplicada. El conocimiento es un bien público y, como tal, el sector privado no invierte suficiente en él. Además, la falta de información acerca de las probabilidades de éxito de un proyecto empresarial explica que las empresas privadas no se embarquen en muchos proyectos, pues no pueden asumir el riesgo asociado. En estas circunstancias, si el bien social del proyecto lo justifica, debe ser el Estado quien asuma el reto. Este es el caso de la investigación básica, muy costosa y demasiado arriesgada 
para las empresas, pero fundamental para la evolución de nuestra sociedad. En estas circunstancias, el Estado debe fomentar y participar en la investigación y, por qué no, recoger parte de los beneficios que genere en el futuro. Para ello, se crean centros de investigación públicos, se fomenta la creación de spin-offs, es decir, empresas surgidas a partir de la investigación realizada, que apliquen en la industria los conocimientos adquiridos y se promueve la investigación en el sector privado. El Estado también debiera participar en la investigación aplicada, que es la que genera el retorno económico, ingresos monetarios y en la explotación económica de los descubrimientos e inventos. Además, si el conocimiento se ha adquirido gracias a la financiación pública, con el dinero de todos, ese conocimiento debería ser público, al alcance de todos. Esto fomentaría la competencia. Actualmente no es ésta la situación habitual y el Estado se queda al margen de los beneficios que obtienen las empresas que se benefician de la investigación pública. En este contexto, la colaboración públicoprivada beneficia principalmente al capital privado.

Mediante esta política de fomento a la investigación el Estado puede determinar qué temas se investigan y qué problemas se solucionan. La selección de las áreas de investigación que merecen recibir más financiación es un asunto complejo y no exento de polémica. A menudo se culpa al Estado de no escoger adecuadamente qué industrias se deben fomentar con la investigación pública y de despilfarrar el dinero. Por lo general, es cierto que el Estado yerra en ocasiones a la hora de seleccionar sectores "vencedores", lo cual es lógico dada la falta de información y el riesgo inherente a toda decisión de esta índole. Precisamente por esto es que las empresas privadas prefieren no arriesgarse si no van de la mano del Estado. Por otra parte, no es menos cierto que la política industrial ha cosechado éxitos en el fomento de diversos sectores (telecomunicaciones, aeroespacial, ordenadores, medicina etc.) a partir de los resultados cosechados por la investigación pública.

La creación de organismos de investigación sirve, además, para suavizar problemas en el mercado laboral y ampliar la demanda de empleo altamente cualificado que, en caso contrario, debería emigrar, dando lugar al fenómeno conocido como "fuga de cerebros". Realmente supone una gran ineficiencia y pérdida de capital humano que personas con un elevado nivel de formación, en muchos casos costeado con dinero público, dejen el país por falta de empleo. 
Esta situación, cuando se da, tampoco habla a favor del espíritu emprendedor de las grandes empresas, su política de investigación, ni de su compromiso con el país en el que operan.

Uno de los principales problemas de la política de investigación y desarrollo tecnológico es la dificultad para medir resultados, especialmente en el ámbito de la investigación básica. Sistemas de control erróneos generan incentivos perversos que gripan el sistema. Por ejemplo, si la calidad del investigador se pondera en función al número de artículos que publica en revistas científicas, lo que generará la política de investigación estatal será precisamente eso: muchos artículos de investigación sean o no útiles.

Un aspecto determinante en el desarrollo de la industria de un país es la legislación sobre propiedad intelectual y patentes. El Estado se enfrenta a una disyuntiva. Si favorece al inventor para incentivar a actividad investigadora y de innovación, se retarda el empleo eficiente del invento, pues la protección crea un monopolio temporal a favor del inventor.

Así, una cuestión fundamental es el tiempo de protección que se concede.

Otra cuestión importante es definir qué se puede patentar y que no. Se trata de un tema importantísimo. Pensemos, por ejemplo, en la ingeniería genética o el interés de grandes multinacionales farmacéuticas por apropiarse de conocimientos de la medicina tradicional.

El Estado también debe estar alerta ante el mal uso de las leyes de protección intelectual y otras las artimañas legales de las empresas para impedir la innovación o lucrarse gracias a patentes que han comprado pero que no piensan utilizar.

Otro tema de vital importancia es determinar cuándo el derecho del inventor a lucrarse por su invento gracias a un monopolio creado por la legislación estatal está por encima de ciertos derechos de los ciudadanos, especialmente el derecho a la vida. La respuesta parece obvia, pero muchos Estados actualmente priorizan el derecho al lucro, como en el caso de las vacunas. Esta situación es especialmente sangrante cuando el Estado ha participado de forma decisiva en el desarrollo de las vacunas.

Finalmente, debemos ser conscientes de que no siempre es necesario proteger la propiedad intelectual para promover la innovación y el avance del 
conocimiento. $Y$ es que, contrariamente a lo que se suele decir, el ser humano no solo se mueve por incentivos monetarios. Ejemplos de esta actividad altruista de colaboración y avance tecnológico los encontramos en el software libre de código abierto o el hardware libre de código abierto, desarrollado por millones de personas sin obtener una retribución económica expresa. El impacto de esta evolución en la mejora de la eficiencia es inmenso, aunque habitualmente se hable poco de él. El Estado debe proteger e incentivar este tipo de investigación colaborativa y desinteresada y sumarse a ella. Una buena política es ser usuario de este tipo de productos, lo que supondrá un significativo ahorro en costes.

Existen numerosos ejemplos de intervenciones de política industrial como remedio a los fallos del mercado. No obstante, es muy habitual que el Estado se extralimite en sus funciones y actúe sin justificación alguna o la forma de actuar esté condenada al fracaso, pues su intervención no mejorará la eficiencia. Estas actuaciones suelen perseguir objetivos mal definidos y, en no pocos casos, tras la excusa de buscar el desarrollo de un sector se esconde el deseo de realizar una política redistributiva, por ejemplo, pero no exclusivamente, mediante la concesión de subvenciones y exenciones fiscales. En estos casos es probable que el Estado haya cedido ante las exigencias de grupos de presión que ven en la política industrial una forma de obtener beneficio rápido y sin riesgo. Los beneficiarios pueden ser empresas concretas, pero también personas físicas o regiones. Por ejemplo, cuando el Estado decide crear un clúster industrial, esto es, fomentar la concentración de empresas que participan, directa o indirectamente en un sector económico concreto, como puede ser la biotecnología. La región donde se instale dicho clúster verá mejorar sus infraestructuras, recibirá cuantiosos fondos públicos y creará empleo. Por desgracia, el éxito de estas medidas de creación de clusters por el Estado es muy, muy limitado. Pero el caso más obvio de política redistributiva disfrazada de política industrial son las subvenciones de diversa índole a empresas. En numerosas ocasiones son precisamente las grandes empresas oligopolísticas o los grandes terratenientes quienes reciben las subvenciones, lo que favorece el statu quo, la concentración de poder y limita la competencia. Piénsese, por ejemplo, en los rescates a grandes empresas (a la Pymes no las rescata nadie). ¿Cuál es el verdadero objetivo de estas subvenciones? ¿Hay un control posterior 
de eficacia y eficiencia? ¿No hay medidas alternativas mejores para alcanzar esos objetivos?

Otro caso en el que la política redistributiva se suele disfrazar de política industrial son los contratos de concesión públicas. Suelen ser para construir obra pública, por ejemplo autopistas, o para gestionar un servicio, por ejemplo, la red de suministro de agua potable o un gimnasio.

En el primer caso, el objetivo es mejorar las infraestructuras de transporte. Mediante la concesión, el Estado consigue que se construya la autopista sin tener que desembolsar el coste. A cambio, generalmente, la empresa constructora obtiene el derecho de explotación de la autovía durante un tiempo determinado, es decir, podrá cobrar un peaje a los usuarios, pero deberá hacerse cargo de los costes de mantenimiento de la autovía. Si realmente la construcción de la autovía está justificada, el contrato de concesión puede ser ventajoso para el Estado. Pero hay que tener en cuenta en qué términos se redacta el contrato de concesión y cómo se controla su cumplimiento. Por ejemplo, una vez adjudicada la concesión, la empresa concesionaria no tiene incentivos en mantener la autovía en un estado óptimo. Por otro lado, presionará para que se le prolongue la concesión. Un aspecto fundamental y muy negativo que es menos conocido es que muchas veces en los contratos de concesión se estipulan una serie de condiciones que deben cumplirse y que, de no hacerlo, implican una indemnización del Estado a la empresa concesionaria. Por ejemplo, en el caso de una autopista, se garantiza que la utilizarán un mínimo de vehículos. Si no se alcanzan, el Estado debe pagar a la empresa concesionaria. De esta manera, la empresa concesionaria tiene garantizado un beneficio mínimo a partir del cual éste puede aumentar indefinidamente. Es decir, tiene beneficio son riesgo, algo completamente impensable en un mercado de competencia perfecta. Por otro lado, el Estado es el que asume el riesgo pero no participa de los beneficios. ¿Es esto eficiente desde el punto de vista de la gestión pública? Es fácil suponer que es relativamente sencillo que las condiciones contractuales sean negativas al Estado y favorables a la empresa concesionaria y el contrato de concesión en realidad sea una manera de favorecer a una empresa amiga (o varias) de los políticos de turno. Pues bien, hemos puesto el ejemplo de la concesión de una autovía, pero esta situación nefasta puede darse con cualquier tipo de concesión. 
Lo primero que debe definirse antes de plantear una actuación estatal es qué objetivo se persigue y si el mercado no puede alcanzarlo solo de forma más eficiente. Muchas veces estas cuestiones no se plantean y el Estado decide que tiene que actuar. Entonces decide, por ejemplo, construir un gimnasio público o una piscina con unas instalaciones fantásticas que cuestan un dineral. Y decide también que la gestión del gimnasio será privada, para ahorrarse el coste de personal y de mantenimiento. Fija los precios máximos que se pueden cobrar a los usuarios y otorga la concesión. En estos casos cabe preguntarse si, efectivamente, la actuación del Estado (normalmente, un Ayuntamiento), está justificada. ¿Es la construcción de un gimnasio o una piscina la forma más eficiente de invertir el dinero público, que podría destinarse a otros fines? ¿Realmente querían los ciudadanos un gimnasio o una piscina? ¿Están dispuestos a pagar por su uso al menos lo suficiente como para cubrir su coste, o deben los demás ciudadanos subvencionarles con el dinero de sus impuestos? ¿Por qué la iniciativa privada no provee suficientes gimnasios y piscinas para cubrir la demanda? Después, se construye el gimnasio o la piscina con dinero público y se decide si la gestión será pública o privada. La gestión pública tiene el inconveniente de que aumenta los gastos corrientes debidos al gasto de personal y el mantenimiento de las instalaciones. Si la gestión es privada, será la empresa concesionaria la que los asuma. Además, se supone que, movida por el incentivo de maximizar su beneficio, conseguirá prestar un mejor servicio incurriendo además en menores costes. Esta teoría es muy bonita y puede ser que, efectivamente, ocurra de esta forma. Pero eso dependerá de cómo se haya redactado el contrato de concesión y el control que ejerza el Estado sobre la empresa concesionaria. En muchas ocasiones, lo que ocurre en realidad es que la concesionaria, para maximizar su beneficio, no contrata suficiente personal e incumple la normativa laboral para reducir el gasto en nóminas. Además, incumple sus obligaciones relativas al mantenimiento de las instalaciones públicas, también para maximizar su beneficio. De esta manera, al concluir el periodo de la concesión, las instalaciones vuelven a manos del Ayuntamiento en un estado deplorable. Lo que se ha conseguido en realidad no es necesariamente una mejor y más económica prestación del servicio, sino más bien lo contrario. El beneficio del empresario se ha sustentado en la explotación de sus empleados y el nulo mantenimiento de las instalaciones. De no ser así, 
es posible que el ahorro total de la gestión privada frente a la gestión pública no fuera tan evidente. Lo más curioso es que, por desgracia, cuando el Ayuntamiento en cuestión arregla y renueva todas las instalaciones, vuelve a ofrecer el gimnasio o la piscina en régimen de concesión y... la otorga de nuevo a la misma empresa. Este hecho, muy habitual, al menos en España, pone de manifiesto una gran ineficiencia estatal. $Y$ es que las concesiones, en numerosas ocasiones, son, como ya hemos indicado, política redistributiva disfrazada de política industrial. Por eso en fundamental cómo se redacta el pliego de condiciones y cómo se produce la adjudicación de las concesiones.

La adjudicación de las concesiones no es, a menudo, un proceso transparente. Además, las opciones que se le presentan al Estado tampoco suelen ser muchas. En muchas ocasiones, solo un grupo reducido empresas pueden aspirar a obtener la concesión, bien porque solo unas pocas empresas están realmente capacitadas, bien porque las condiciones que deben cumplir se redactan ad hoc para favorecer a empresas concretas. Además, hay poca imparcialidad real en el proceso de adjudicación, por ejemplo a la hora de ponderar y valorar los criterios objetivos en base a los cuales se adjudica la concesión. Por ejemplo, un criterio puede ser la experiencia de la empresa en el sector, pero la empresa a la que se adjudica la concesión solo tiene unos días de vida. Todo lo expuesto pone de manifiesto cómo los contratos de concesión favorecen la corrupción y la transferencia de fondos públicos del sector público al sector privado. Estos casos son muy numerosos y están muy documentados. Por mencionar un ejemplo, el caso de las inspecciones técnicas de vehículos, la ITV. Se trata de un servicio obligatorio que puede prestarse en régimen de competencia perfecta, o podría hacerlo el propio Estado, pero que en muchos lugares se presta en régimen de concesión. ¿Por qué esta opción? Se ha comprobado cómo hay intereses oscuros detrás de esta decisión, con corrupción y tratos de favor.

Con todo esto no estoy diciendo que los contratos de concesión sean necesariamente negativos, sino que deben emplearse con suma cautela y con total transparencia. Por otro lado, el Estado puede utilizar estos contratos para influir positivamente en la economía, por ejemplo, primando como criterio de concesión el que la peticionaria sea una cooperativa o una pyme, o prohibiendo la adjudicación a empresas que hayan sido condenadas por fraude fiscal o por 
falsear la competencia para repartirse el mercado de las concesiones en un sector determinado. Sorprendentemente, en la actualidad, en España, esto no es así. Bueno, no tan sorprendentemente.

Al margen de las concesiones, el Estado puede decidir intervenir directamente en la economía a través de sus propias empresas mediante el sector público empresarial.

\subsubsection{EL SECTOR PÚBLICO EMPRESARIAL}

El sector público empresarial está formado por las empresas que son propiedad del Estado. Mediante estas empresas el Estado participa directamente en la producción de bienes y servicios, siendo el propietario de los medios de producción. Normalmente se vincula a los sectores minero, manufacturero, energético, infraestructuras, telecomunicaciones y financiero. Las finalidades principales son fomentar el desarrollo y la competitividad de un sector industrial, promover el crecimiento económico de una región y generar empleo o asegurar la oferta de un bien o servicio en el mercado.

Dentro de las políticas de asignación de recursos, la creación de un sector público empresarial es de las más controvertidas. Como veremos a continuación, la historia de estas políticas es pendular: de su inexistencia hasta 1930 se pasó a un periodo de auge del intervencionismo estatal que permitió el crecimiento del sector público empresarial en muchos países. Esta situación duró, con diferente intensidad, hasta 1980. A partir de entonces la tendencia imperante defiende un Estado con poca participación directa en la actividad económica, dejándose la iniciativa al sector privado y limitándose el Estado a subvencionar y rescatar empresas.

Sin remontarnos más allá en la historia, se puede decir que las empresas estatales eran totalmente anecdóticas antes de la década de 1930. La gran crisis económica y financiera de 1929 exigió la intervención estatal directa en la economía para fomentar el empleo y en muchos países se iniciaron programas 
de obra pública. Más tarde, la Segunda Guerra Mundial obligó a muchos países a implementar una economía de guerra, en la que el Estado podía planificar toda la economía con el fin de disponer de los recursos necesarios para afrontar el esfuerzo bélico. El resultado en EEUU fue un crecimiento del PIB espectacular y la salida definitiva de la depresión económica. Tras esta experiencia favorable de la intervención del Estado en la economía, muchos Estados, especialmente los europeos, se lanzaron a una dinámica política de fomento del sector público empresarial. En el contexto de las economías mixtas, la importancia relativa de las empresas nacionalizadas, es decir, propiedad del Estado, en la producción y el empleo creció paulatinamente y llegó a ser muy importante en regiones concretas. La crisis de la década de 1970 dejó al descubierto el peligro de un sector público empresarial exuberante que generaba ineficiencias en algunas actuaciones y que ocasionaba grandes gastos a las arcas públicas, las cuales tuvieron que sostener durante cierto tiempo a empresas públicas deficitarias. Ante esta evolución, en la década de 1980 las voces contrarias a al sector público empresarial, que ya venían atacándolas (no sin justificación) desde hacía años, ganaron el debate. La corriente neoliberal imperante desacreditó absolutamente este tipo de políticas ante la opinión pública, consiguiendo que se aceptara el dogma de que el sector público siempre es más ineficiente que el privado. Dentro del espíritu de la globalización y la libre competencia a nivel mundial que se propugnaba, la participación directa del Estado en la economía era inconcebible. Por este motivo, muchos Estados llevaron a cabo un proceso de privatización masivo, en el que la mayoría de las empresas estatales que gestionaban mercados monopolísticos y otras empresas públicas rentables se vendieron a inversores privados. La reconversión y eventual liquidación de las empresas no rentables quedó en manos del Estado. El proceso privatizador no comenzó a la vez en todos los países ni tuvo la misma intensidad, pero se puede decir que se desarrolló principalmente en las décadas de 1980 y 1990, si bien los Estados siguen privatizando de cuando en cuando empresas rentables. En estas circunstancias, con un sector industrial y financiero público casi inexistente, la política industrial de los Estados en los últimos años se ha centrado en otorgar subvenciones al sector privado, preferentemente a las grandes empresas, y desregular comercio internacional, siguiendo las teorías neoliberales. 
Es importante resaltar que la situación referida en los párrafos precedentes describe, a grandes rasgos, la evolución del sector público empresarial en EEUU y Europa occidental. Obviamente, en los países de la esfera comunista la situación era otra. Además, es básico matizar que las políticas en muchos países del este asiático han sido y son muy diferentes a las europeas 0 estadounidenses. Por no remontarnos en el tiempo para hablar de Japón o Corea, un caso impresionante es el de China, que lleva a cabo una política industrial muy activa, siendo el Estado propietario absoluto o parcial de muchas empresas importantes.

Los argumentos que justifican la existencia de un sector público empresarial para mejorar la eficiencia son los mismos que justifican cualquier intervención económica del Estado: los fallos del mercado. Los principales fallos son la existencia de monopolios naturales y los mercados. A estos argumentos se puede añadir la defensa de la soberanía económica, que está más relacionada con la obligación del Estado de defenderse de posibles agresiones extranjeras, también de naturaleza económica, y que son más peligrosas cuando mayor es la dependencia exterior. Por lo tanto, y esto es importante, la política industrial no justifica que el Estado intervenga en cualquier sector económico y, por ejemplo, se dedique a la producción de zapatos o de pantallas de televisión, tareas que realizará mejor el capital privado.

Los monopolios naturales son aquellos en los que es ineficiente que actúe más de una empresa. El ejemplo paradigmático son las industrias de redes, pues es ineficiente tener redes superpuestas. Por ejemplo, dos líneas ferroviarias que unan Valencia y Madrid. Ante la falta de competencia, una opción es que sea el Estado quien realice la actividad económica en cuestión, de forma que ninguna empresa privada se pueda beneficiar de su posición de monopolista. Esto sucede en casos como la construcción y gestión de la red de agua potable y alcantarillado, la red eléctrica de larga distancia, puertos y aeropuertos o el ferrocarril. Por eso en muchos países las empresas que se encargan de estos servicios son de titularidad pública.

Es posible que con el paso del tiempo la situación que generaba el monopolio desaparezca. Por ejemplo, antes de la aparición de la telefonía móvil había una 
sola red telefónica y, por lo tanto, un monopolio natural. En muchos lugares el servicio telefónico era gestionado por una empresa pública. Los cambios tecnológicos destruyeron el monopolio natural y permitieron abrir el sector a la competencia. También es posible abrir un monopolio natural a la competencia, de forma que no se necesite la intervención de una empresa pública. Por ejemplo, se genera competencia "en el mercado", cuando varias empresas pueden prestar simultáneamente, compitiendo entre sí, el servicio de transporte de ferrocarril de viajeros entre dos ciudades. Otra opción es la competencia previa, llamada competencia "por el mercado", para conseguir, mediante una subasta, por ejemplo, el contrato o la adjudicación del Estado que garantiza el acceso al monopolio. Esto ocurre, por ejemplo, cuando el Estado otorga una concesión para gestionar la red de suministro de agua potable. El monopolio sigue existiendo, pero ya no lo gestiona el Estado que, a cambio, ha cobrado un canon.

Actualmente los economistas estudian cuál es la mejor manera de que sea el sector privado quien se encargue de realizar las inversiones y gestionar las industrias de redes y han identificado numerosos problemas, por lo que no se puede decir que la mejor opción sea siempre la participación de las empresas privadas. Además, mantener empresas activas en estos sectores permite al Estado disponer de información interna del sector que es muy relevante a la hora de regular y legislar o para implementar políticas que favorezcan la competencia.

Las imperfecciones en los mercados pueden justificar la creación de empresas estatales otras muchas ocasiones.

En mercados donde pocas empresas concentran gran poder, los llamados oligopolios, como es el caso del sector financiero o el sector de generación de electricidad, al margen de la regulación sectorial, es también razonable la creación de empresas estatales para fomentar la competencia. $Y$ es especialmente importante en sectores, como el financiero, donde la concentración del mercado y sus ramificaciones económicas son de tal envergadura que la quiebra de una empresa obligue al Estado a intervenir y rescatarla. En estos casos, lo más conveniente es intervenir en el mercado para limitar tales niveles de concentración y promover un mercado de competencia perfecta y, de no ser posible, competir en el mercado a través de una o varias 
empresas públicas. $\mathrm{Y}$, en el caso de tener que rescatar a las empresas con dinero público, no es descabellado que el Estado asuma la gestión de la empresa que ha demostrado ser tan ineficiente y peligrosa en manos privadas.

El Estado puede participar en un sector en el que participan las empresas privadas pero éstas no actúan en todos los segmentos del mercado, como ocurre con la industria del seguro o con la industria bancaria. En estos casos es razonable que el Estado intervenga para ofrecer servicios como seguros para las cosechas para los agricultores y cree compañías de seguros. $\mathrm{O}$ bancos públicos para ofrecer créditos a las pequeñas y medianas empresas.

Por otro lado, el Estado puede actuar y crear sus propias empresas con el fin de impulsar un sector o diversificar la economía cuando la iniciativa privada se muestra pasiva. Esto puede ocurrir cuando la clase empresarial es reticente a asumir riesgos, por ejemplo, porque no tiene espíritu emprendedor o porque no puede asumir cierto nivel de incertidumbre o simplemente tiene alternativas de inversión que le resultan más interesantes. Por ejemplo, tal y como hemos visto al hablar del papel del Estado en el fomento de la investigación, parece razonable que el Estado, después de costear un proyecto de investigación, aproveche los resultados obtenidos para crear sus propias empresas y recibir un retorno a esa inversión.

Las imperfecciones del mercado laboral pueden justificar que el Estado asuma el papel de creador de empleo, por ejemplo, a través de la creación y mantenimiento de las empresas públicas. Esta medida puede tener también un fuerte impacto en la distribución territorial de la renta. No obstante, el argumento de la creación de empleo es muy peligroso. Casi cualquier intervención en la economía se puede justificar con una supuesta creación de empleo o con el argumento del crecimiento económico. Pero, de esta forma, se justificaría un crecimiento indefinido, ineficaz e insostenible del sector público en general y también del sector público empresarial. De ahí la necesidad de que toda política pública, también la política industrial, defina claramente los objetivos que persigue. Cuando éstos no se explicitan, el Estado tiende a sobreactuar y a generar ineficiencias. A todos nos vienen a la mente ejemplos de empresas públicas que son o han sido un agujero sin fondo en las arcas públicas. 
Por otro lado, si se crea una empresa pública con la finalidad de crear empleo, ¿cómo se valora su desempeño? ¿por el número de puestos de trabajo creados? Medir la eficiencia de las empresas públicas es siempre complejo, pues no siempre prima la obtención de beneficio, sino que existen otros fines sociales difíciles de cuantificar, pero, en cualquier caso, se debe intentar. Sin objetivos claros, es imposible incentivar la buena gestión y la innovación.

En muchas ocasiones, el Estado, a través de sus empresas, es el empleador más importante de una región y las empresas privadas de la zona dependen de la actividad de las estatales. En esas circunstancias resulta especialmente complejo realizar una buena gestión de personal en las empresas públicas, por no hablar de reducir la plantilla. Los grupos de presión locales, los sindicatos y los votantes tratarán de impedir a toda costa cualquier actuación de las empresas públicas contraria a sus intereses. También se opondrán los políticos locales que hayan tejido redes de clientelismo gracias a estas empresas y temerán perder votantes, así como los políticos que vean en la defensa del statu quo una posibilidad de ganarlos. Esta situación ata de pies y manos a los gestores públicos, dejándoles un margen de actuación muy limitado. Lógicamente, la eficiencia de las empresas públicas en estas circunstancias se resentirá y, tarde o temprano acabará incurriendo en pérdidas.

En línea con lo anterior, uno de los problemas de los proyectos empresariales estatales es cómo se determina que el proyecto ha sido fallido y debe abandonarse. Es decir, cuándo cerrar la empresa pública. Es fácil suponer que habrá una fuerte oposición al cierre por aquellas personas que se vean afectadas por él, mientras que los demás, los que pagan los gastos ocasionados por la empresa deficitaria, sean menos activos en defender el cierre.

Finalmente, un argumento que puede impulsar al Estado a desarrollar una política industrial e intervenir directamente en la producción de bienes y servicios o influir en la asignación de recursos privados es la protección de la soberanía económica nacional. Se trata de garantizar la independencia frente al exterior del suministro de algunos productos y servicios que se consideran fundamentales para el sostenimiento del Estado y la economía. Es decir, hay ciertos sectores que no se pueden dejar absolutamente en manos extranjeras. En estos casos, 
ante la falta de empresas locales, el Estado puede optar por crear sus propias empresas. Vivimos en una economía globalizada y las relaciones comerciales entre países son muy intensas, por lo que también lo es el grado de interdependencia y no nos paramos a pensar que, en ocasiones, las grandes empresas que pensamos que son nacionales en realidad responden a intereses extranjeros. En caso de conflicto o inestabilidad económica, es posible que estas empresas no prioricen a la economía y la población local. En este contexto, es defendible, pero no estrictamente necesario, que el Estado disponga de sus propias empresas en determinados sectores estratégicos. En el grupo de sectores estratégicos encontramos, desde luego, la industria armamentística. Pero también otros como el sector energético, el sector financiero, el sector tecnológico o el agropecuario.

A pesar de los argumentos que pueda haber a favor de que el Estado intervenga en la economía a través de sus propias empresas, hemos observado algunos problemas que surgen cuando se elige esta opción. Por ejemplo, actúan en ámbitos en los que no está justificada la intervención estatal. Su gestión puede ser nefasta y corrupta si no están sometidas al correspondiente control, por lo que se pueden convertir en meros instrumentos para implementar medidas redistributivas poco confesables y favorecer a determinados grupos en contubernio con los gestores públicos. Pueden ser muy ineficientes y despilfarrar enormes cantidades de recursos públicos, que son detraídos de otras políticas, por ejemplo realizando malas inversiones, contratando más personal del necesario o pagando sueldos elevados. Además, en el caso de competir en el mercado contra empresas privadas, no siempre es fácil garantizar que las empresas estatales juegan en igualdad de condiciones con sus competidores privados. También resulta muy complicado para el Estado dar por fracasado un proyecto empresarial y liquidar una empresa pública o venderla al sector privado, salvo que la empresa sea rentable. En ese caso surgen nuevos problemas. Y es que, cuando una empresa pública es rentable, la presión para que el Estado la privatice es muy grande. En la actualidad, en España, todas las grandes empresas estatales están ya en manos de inversores privados, muchos de ellos extranjeros, que son quienes disfrutan de los beneficios. En este contexto, los incentivos que tiene un Gobierno para crear empresas públicas rentables son 
reducidos, pues el siguiente Gobierno podría privatizarlas y llevarse los frutos de dicha privatización. Estos frutos son, por un lado, los ingresos para el Estado por la venta y, por otro, los favores personales que recibirán los políticos de las empresas compradoras. Por lo general, en España, el Estado ha vendido las empresas públicas en unas condiciones muy favorables para los compradores y, por lo tanto, muy malas para el Estado y los ciudadanos.

Finalmente debemos ser conscientes de que la actuación privada puede ser también ineficiente, especialmente cuando no opera en un mercado de competencia perfecta, tal y como venimos repitiendo a lo largo del libro.

Podemos concluir este apartado sobre la política industrial recordando que no es cierto que el sector privado sea siempre más eficiente que el sector público. Tanto la actuación de las empresas privadas como la política industrial estatales tienen sus luces y sus sombras. Depende de las circunstancias, que, básicamente, están relacionadas con el control que se pueda ejercer sobre las empresas y el Estado. La falta de control siempre deviene en despilfarro, corrupción y concentración de poder. Por desgracia, no hay una fórmula perfecta que permita eliminar estos riesgos, pues las estrategias de los que se quieren aprovechar de su posición privilegiada se van adaptando a las nuevas circunstancias.

Que la política industrial puede ejercer un impulso formidable en el crecimiento económico lo demuestran casos como el de Japón, Corea o China. También hay numerosos ejemplos que revelan la ineficiente asignación de recursos que pueden hacer las empresas privadas que participan en mercados imperfectos desregulados, como los casos recientes en el sector inmobiliario o en el sector financiero, que recibió cuantiosas subvenciones directas e indirectas del Estado. Ineficiente gestión de recursos que tuvo un elevado coste para el Estado y un enorme coste social. 


\subsubsection{CAMBIO DE PARADIGMA}

Actualmente, la política industrial de muchos Estados, si bien se quiere definir como "neoliberal", es decir, de defensa acérrima del mercado y escasa participación estatal, tiene un claro corte mercantilista. En el mercantilismo el Estado subvencionaba a las empresas privadas y creaba monopolios privados que gozaban de grandes privilegios. El poder del Estado se ponía a disposición de estas grandes empresas e incluso se llevaban a cabo guerras y conquistas territoriales para asegurarles el acceso a materias primas y nuevos mercados. Estas actuaciones mercantilistas nos recuerdan algunas intervenciones actuales de los Estados para favorecer a las grandes empresas en tiempos de crecimiento económico y en tiempos de crisis. De hecho, parece que la política industrial de muchos Estados esté orientada a garantizar la permanencia del statu quo y a promover aún más la concentración del poder económico. Como consecuencia de este enfoque, especialmente en Europa, se impide la destrucción creativa preconizada por Schumpeter (según la cual las empresas menos competitivas son sustituidas por otras nuevas), las grandes empresas son descendientes directas de empresas creadas hace más de cien años y se frena toda innovación disruptiva. Cualquier cambio debe ser dirigido por las grandes empresas predominantes, los diferentes "campeones nacionales", para garantizar que su poder permanece intacto. El resultado es que las empresas europeas van perdiendo competitividad lenta, pero incesantemente y no son punteras en los nuevos sectores emergentes.

Poner la política industrial al servicio de los "campeones nacionales" es un error que se explica por el poder alcanzado por sus lobbies. Frente a esa concepción de la política industrial, el Estado debería dejar de apoyar a las empresas que dominan el mercado e impiden que éste desarrolle todo su potencial gracias a la competencia perfecta entre empresas. En lugar de eso, el Estado debe potenciar las pequeñas y medianas empresas y participar directamente en algunos mercados. $Y$ debe liderar la investigación puntera de forma activa, sin limitarse a subvencionar la investigación de las grandes empresas. Pero, además, debe abrir los ojos ante las nuevas (y viejas) formas de crear riqueza al margen de los mercados competitivos tradicionales, como las redes descentralizadas de trabajo 
colaborativo que, sin ofrecer incentivos monetarios, impulsan a las personas a compartir su esfuerzo y creatividad con la sociedad. $Y$ es que los mercados son lugares de intercambio y en ellos también se puede fomentar la colaboración y la confianza. El Estado debe promover y potenciar todas las posibilidades que ofrecen las tecnologías de la información y la comunicación (TIC), maximizando los beneficios que se pueden extraer del software libre de código abierto, hardware libre de código abierto o las impresoras 3D. En este contexto, debe actualizar las leyes de propiedad intelectual y patentes, pues es fundamental que la información se pueda compartir libremente y esté disponible para toda la sociedad y que las grandes empresas no puedan utilizar la legislación para frenar la evolución tecnológica. 



\section{FALLOS DEL SECTOR PÚBLICO}

Hasta este momento, a lo largo del libro se ha explicado por qué es necesario que el Estado intervenga en la economía y de qué maneras puede intervenir. Así, hemos explicado que la falta de mercados de competencia perfecta y los fallos existentes en los mercados de competencia perfecta justifican la intervención del Estado para evitar ineficiencias. Además, el Estado debe intervenir en aquellos ámbitos en los que es necesario un nivel muy elevado de coordinación que no se puede conseguir con la iniciativa privada, como son las políticas macroeconómicas. Al margen de estas políticas, el Estado influye en la distribución de la renta e implementa políticas redistributivas y de asignación de recursos para alcanzar sus objetivos. Se ha comentado también cómo en numerosas ocasiones esos objetivos que persigue el Estado no se encuentran especificados, ni tienen un orden jerárquico, o cómo las actuaciones del Estado se desvían claramente del objetivo principal que defiendo en este libro (y que no tiene por qué ser aceptado por todo el mundo): la creación de un entorno socioeconómico que permita a las personas desarrollar su personalidad y buscar su felicidad libremente. Y es que el hecho de que exista una justificación teórica para la actuación del Estado no garantiza en absoluto que el Estado vaya a actuar correctamente, en el sentido que defendemos aquí.

Llegados a este punto conviene subrayar que el que la actuación del Estado esté justificada en algunos ámbitos y en ciertas circunstancias implica, sensu contrario, que fuera de esos ámbitos y esas circunstancias su actuación no es recomendable, el Estado debe abstenerse de actuar. Es importante que el Estado no se extralimite en sus funciones, pues se corre el riesgo de un intervencionismo excesivo que redundará en menor eficiencia económica. Además, a mayor intervencionismo, a mayor poder del Estado, mayor exposición habrá a los riesgos que entraña una mala actuación estatal. Tan negativo es tener demasiada intervención como tener demasiado poca. Un Estado excesivamente intervencionista en el ámbito económico magnificará el poder de aquellos que controlen el poder Estatal, que no tienen por qué ser los ciudadanos, sino serán más bien los políticos, los burócratas y los grupos de 
presión, y beneficiará sus intereses. En mi opinión, uno de los fallos fundamentales del sistema económico comunista es que no previó y no luchó eficazmente contra el poder de una nueva clase social, la de los burócratas, que gozaron de una enorme influencia sobre la actuación estatal.

En caso de que el Estado renuncie a intervenir y a dirigir el funcionamiento de la economía, serán otros, las grandes corporaciones y las grandes fortunas, los que asuman los mandos y detenten el poder. $Y$ es que, si el Estado no asume su papel y no interviene para defender la economía de mercado (como viene siendo la tendencia en los países occidentales en las últimas décadas, de marcado carácter neomercantilista), no es que haya más libertad, es que los que dirigen son otros, menos visibles y sin tener que rendir cuentas a la ciudadanía. Obviamente, se dedicarán a servir a sus intereses particulares, generando formidables ineficiencias en el sistema económico.

A continuación vamos a describir las fases o análisis que deben hacerse en cada actuación del Estado. Después se analizará quiénes originan los fallos en la actuación del Estado y cómo influyen en que la actuación del sector público sea ineficiente, por ejemplo al despilfarrar recursos o fomentar la acumulación de poder económico. Una vez más, veremos que las ineficiencias se deben a la falta de verdadero control, en este caso por parte de los ciudadanos, que son quienes, en una sociedad democrática, debieran ejercer el control sobre los poderes del Estado y la Administración Pública. Esta falta de control aumenta el poder de otros agentes que influyen en la actividad del sector público, especialmente de ciertos grupos de presión que dirigen las decisiones de los políticos. Huelga decir que los fallos del sector público afectan a todas las políticas estatales, desde la política monetaria hasta la política industrial.

El breve análisis que vamos a presentar es forzosamente muy general, pues los fallos y deficiencias son muy diversos y varían en cada época y país.

Vamos a nombrar los principales agentes que pueden generar fallos, comportamientos ineficientes, en la actuación del sector público y cómo los generan. En primer lugar hablaremos de los grupos de presión, los llamados lobbies, cuya misión es influir directamente en las decisiones políticas y generar opiniones favorables en los ciudadanos. A continuación veremos cómo los propios políticos y el aparato burocrático influyen también en la política estatal 
para defender sus propios intereses. Después, comentaremos cuál es la actuación de los votantes y cómo ésta también puede fomentar la ineficiencia estatal. Finalmente, mencionaremos el papel de los medios de comunicación.

\subsection{FASES DE LA ACTUACIÓN ESTATAL}

Para garantizar la correcta actuación del Estado en la economía, toda intervención debiera seguir una serie de fases o protocolos, tanto si se trata de política macroeconómica, redistributiva o de asignación de recursos. En primer lugar, se debe especificar qué objetivo se quiere alcanzar y cuál es la justificación de la intervención del Estado. En segundo lugar, se debe precisar la forma de la actuación estatal. Y, en tercer lugar, debe controlarse la actuación en términos de eficiencia. Veamos estos puntos con algo más de detalle.

En primer lugar, se debe identificar un problema específico que requiera solución y debe justificarse que sin la intervención del Estado ese problema no se solucionará. Ya hemos comentado que existen numerosos fallos que justifican esa actuación del Estado. Pero eso no implica que la actuación del Estado vaya a ser siempre la correcta y que vaya a solucionar el problema sin crear otros. El Estado, como veremos, tiene fallos al igual que el mercado. Uno de los fallos del Estado es su tendencia a sobreactuar, a encontrar justificaciones a su actuación cuando no la hay. Además, una vez iniciada una actuación le resulta muy difícil dar marcha atrás, la inercia de la actuación estatal es muy fuerte. Por otro lado, los objetivos específicos de su actuación tampoco están convenientemente precisados, lo que deriva en actuaciones o políticas poco eficientes. O se proponen políticas que benefician a unos pero perjudican a otros, que no son tenidos en consideración.

Veamos un caso sencillo: Los productores de azúcar se quejan de que las empresas extranjeras ofrecen unos precios muy bajos y que no pueden competir contra ellas, por lo que su situación económica es precaria y van a tener que despedir a muchos trabajadores. Ante esta queja, el Estado decide que tiene que actuar para proteger la industria nacional y el empleo, por ejemplo, mediante la 
imposición de aranceles o subvenciones directas a las empresas. Las primeras cuestiones que debemos plantear son: ¿Qué problema se quiere solucionar exactamente? ¿Qué fallo del mercado se quiere corregir?

En segundo lugar, se debe decidir cómo se actúa, teniendo en consideración siempre que en la jerarquía de objetivos del Estado el más alto es el bienestar de los ciudadanos. Esto es fundamental dejarlo muy claro, pues muchas actuaciones que buscan solucionar problemas mal definidos lo que hacen en realidad es disminuir la calidad de vida de los ciudadanos. En el ámbito de la política macroeconómica nos encontramos con esta problemática, por ejemplo, cuando para alcanzar un objetivo intermedio como la reducción del déficit del Estado se toman medidas que directamente perjudican la calidad de vida de millones de ciudadanos, como la reducción del gasto sanitario, frente alternativas como reducir el gasto militar o las subvenciones a los partidos políticos, o subir los impuestos a los bienes de lujo.

En el ámbito de la asignación de recursos, hay que cuestionarse si la actuación del Estado fomentará la competencia o si, por el contrario, favorecerá la concentración de poder y el statu quo. Y hay que decidir cómo se va a articular la intervención del Estado, si mediante regulación, actuación directa en la producción de bienes y servicios, coordinando la actuación de la iniciativa privada, mediante subvenciones, facilitando financiación a las empresas, subcontratando a empresas privadas, adjudicando concesiones... las posibilidades son muy numerosas. Para tomar la decisión correcta es necesario disponer de información. Y se deben analizar todas las alternativas, incluida la de no actuar. La actuación debe buscar la sencillez y simplicidad y debe facilitar el control posterior. Es particularmente importante considerar todos los puntos de vista y las implicaciones para todos los sujetos económicos, no solo para los grupos de presión que intentarán influir activamente en la decisión del Estado. Siguiendo con el ejemplo anterior de los productores de azúcar, en el caso de que el Estado decidiera actuar (aunque realmente no hay justificación para ello), ¿cómo la hará? ¿Mediante una subvención? ¿Aranceles para encarecer las importaciones? Si se toman estas medidas se está alterando la asignación de recursos y se está realizando una política de redistribución que beneficia a los empresarios y a los empleados, aunque no con la misma intensidad, 
probablemente. Los perjudicados son los que han estado ausentes durante el proceso de decisión: en el caso de la subvención, todos los contribuyentes y en el caso de los aranceles, los consumidores de azúcar, que deberán pagar un precio más elevado. En cualquier caso, se ha limitado la competencia, se ha protegido el statu quo y se ha impedido el proceso de renovación empresarial identificado por Schumpeter, pues recursos que podrían destinarse a fines más eficientes quedan atrapados en el ineficiente sector azucarero nacional. El fin que busca esa política, ¿se ha alcanzado de la manera más eficiente? Si el fin era garantizar unos ingresos a los empleados, tal vez una política redistributiva fuera menos gravosa para las arcas públicas y liberaría recursos para otros sectores.

En tercer lugar, debe medirse la eficiencia de la política estatal. Debe comprobarse si se ha alcanzado el objetivo (control de la eficacia) y con el empleo de cuántos recursos directos e indirectos (control de costes). ¿Ha sido mejor actuar que no actuar? El control constante permite identificar posibilidades de mejora en la política y también identificar opciones alternativas. Obviamente, debe determinarse bajo qué circunstancias se entiende que la política ha fracasado y debe dejar de implementarse.

En algunos casos implementar controles de eficacia y eficiencia básica es sencillo, pero suele ser la excepción. Se puede recurrir al uso de indicadores, pero estos introducen incentivos no deseados en la actuación de los agentes afectados. Por ejemplo, podemos suponer que un buen profesor es aquél que motiva a sus alumnos, les inculca su amor por la materia que explica, por lo que los alumnos la estudiarán con pasión y obtendrán buenas calificaciones. Por lo tanto, podemos pensar que un buen indicador de la calidad de un profesor es la nota media que obtengan sus alumnos. Al margen de muchísimas consideraciones importantes, es obvio que este indicador no mejorará necesariamente la calidad de la enseñanza, simplemente hará que suba la nota media. Sirva este sencillo ejemplo para ilustrar los problemas asociados a los indicadores. Además, en no pocas ocasiones, el uso de indicadores trae aparejado un alto coste para diseñarlos, recoger la información necesaria y aplicarlos. No obstante, sí que es posible y necesario emplear diversos indicadores y otros controles para fiscalizar la actividad pública. Para ello, el 
primer paso es la transparencia, facilitar toda la información con el mayor grado de detalle. Con este simple gesto, la sociedad civil, los ciudadanos seguro que se encargan de controlar al sector público (con bajo coste para el Estado) y presentar, por ejemplo, rankings de las actuaciones más absurdas de los políticos en cada ámbito o el de los servicios más ineficientes de cada Ayuntamiento. Hay que confiar en las múltiples cualidades de los ciudadanos.

Como veremos a continuación, los grupos de presión, burocracia, votantes intervienen a lo largo de todo el proceso para defender sus intereses e influyen en la política final, que puede acabar siendo completamente desacertada y contraria a los objetivos a los que se supone que aspiran y que justifican la intervención del Estado. Por ejemplo, las empresas pueden conseguir que se eliminen impuestos medioambientales, que se subvencione a sectores obsoletos e ineficientes o que se creen oligopolios; los directivos de las empresas públicas rentables avalarán su privatización, curiosamente, cantando las virtudes de la gestión privada, donde ganarán mayores sueldos; los empleados de las empresas públicas ineficientes presionan para el que Estado mantenga las empresas y sus empleos, aunque supongan un coste elevadísimo a las arcas públicas. Los burócratas defenderán el gigantismo del Estado, se opondrán a las medidas que impliquen mayor transparencia y control externo ciudadano y defenderán las opciones inmovilistas. Los votantes, por su parte, pueden estar en contra de medidas macroeconómicas que frenen un crecimiento económico que ocasionará una profunda recesión o contra actuaciones para minimizar el cambio climático.

Cuando la decisión Estatal queda cautiva de intereses ajenos al Estado, es muy probable que éste sea ineficiente en su actuación y ésta deje de estar justificada.

\subsection{LOS GRUPOS DE PRESIÓN}

Gran parte de las ineficiencias del Estado se deben, como acabamos de adelantar, a su interacción con otros agentes económicos. Otras se deben al comportamiento de agentes que forman parte de la propia estructura de estatal. 
Entre los pertenecientes al primer grupo destacan los lobbies o grupos de presión.

Los lobbies son grupos organizados en defensa de sus propios intereses que buscan influir en la actuación del Estado y actúan al margen del proceso electoral. En la actualidad, los lobbies más influyentes son los creados por las grandes empresas, muchas de ellas multinacionales, y nos vamos a centrar en su actuación. En algunos países, los grupos religiosos, como la Iglesia Católica, constituyen grupos de presión de tremenda influencia, por lo general defendiendo la visión económica de la oligarquía en el poder. Hace varias décadas, los sindicatos también eran un grupo de presión con bastante fuerza, cuando el número de trabajadores sindicados era mucho más elevado y había muchas empresas públicas. Pero esa época ya pasó en casi todos los países. Los grupos de presión con menos poder son generalmente las denominadas ONGs, organizaciones no gubernamentales, que tienen un interés sectorial, por ejemplo la defensa del medioambiente o la defensa de los consumidores y usuarios, y que se financian en muchos casos con aportaciones de ciudadanos (a veces es su única fuente de financiación) y los Estados.

El poder de los lobbies viene determinado por el número de miembros de la organización, su impacto mediático en la opinión pública y, sobre todo, por la capacidad de obtener financiación, pues, al fin y al cabo, es el dinero el que les permite realizar sus actividades. Los lobbies empresariales son, con mucho, los más poderosos. Y es que resulta más fácil formar un grupo de presión pequeño de empresas con una finalidad común (por ejemplo, empresas productoras de electricidad que quieren presionar al Estado para que desregule el mercado eléctrico), que uno formado por los millones de clientes de dichas compañías. En el primer caso, los beneficios que se pueden obtener por presionar al Estado son cuantiosos para cada una de las empresas implicadas y la probabilidad de éxito no es baja en muchos casos. El coste, comparado con el beneficio potencial, es muy bajo. Y es fácil evitar "polizones", es decir, que haya empresas que no contribuyan a financiar al lobby pero que se beneficien de los resultados obtenidos por él. Además, el objetivo del lobby estará perfectamente alineado con la razón de ser de las compañías, que es obtener beneficio, así que su actividad se puede entender como una parte más del negocio a la que se dedican 
recursos y personal fijos con los que intentar presionar e influir todos los días del año, año tras año. Por el contrario, un grupo de presión formado por los clientes, por ejemplo, de las compañías eléctricas, lo tiene mucho más difícil. Aunque son muchos, el problema del polizón es muy grande, por no hablar de la coordinación y de cómo llegar a todos los potencialmente interesados y ganar su confianza. Los costes, la cuota de afiliación, por ejemplo, es un coste real e inmediato, frente a un potencial beneficio futuro y muy incierto. Si, además, quiero dedicar tiempo a participar activamente en las actividades de la organización, el coste aún será mayor. Por otro lado, el entusiasmo de cada uno de los miembros es limitado, pues deben dedicar sus energías a otros menesteres, conseguir que baje el precio de la electricidad no es su objetivo vital. El análisis coste-beneficio depara resultados muy diferentes en el caso del grupo de presión empresarial y la asociación de consumidores.

Centrándonos ya en los lobbies empresariales, podemos decir que buscan siempre maximizar su beneficio neto, para lo que pueden buscar alcanzar diversos objetivos intermedios, como modificaciones en la legislación sectorial y laboral, medidas proteccionistas, bajadas de impuestos, subvenciones etc.

Por ejemplo, las empresas pueden exigir al Gobierno modificar la regulación en su sector y de esta manera evitar tener que competir en un mercado de competencia perfecta. Así pueden eliminar a competidores o asumir mayores riesgos que les permitan generar más beneficios, como ocurrió con el sector financiero. Las regulaciones favorables pueden permitirles contaminar más o pagar menos a los trabajadores, con el consecuente descenso de los costes.

Pueden proponer medidas arancelarias como subir los aranceles a los productos competidores y bajarlos a los productos que necesitan en su proceso productivo. Pueden presionar para reducir o eliminar ciertos impuestos, o para tener una legislación que facilite las transferencias de dinero a los paraísos fiscales y otras tretas con las que minimizar el pago de impuestos. Incluso pueden defender amnistías fiscales.

También pueden exigir recibir trasferencias del Estado, que pueden adoptar muy diversas formas, como subvenciones a fondo perdido o rescates empresariales cuando la gestión privada ha sido deficiente. En otros casos, pueden tener al 
Estado como cliente que les garantiza jugosos beneficios, como en el caso de concesiones públicas y contratos públicos.

Los objetivos que persiguen los grandes lobbies empresariales cuando presionan al Estado (menos riesgo, menos costes, más ingresos, más beneficio), generan necesariamente enormes ineficiencias económicas, como se ha evidenciado en el caso del sistema financiero y las sucesivas crisis recientes, implican mayor concentración de poder y ponen en riesgo el sistema democrático.

Como hemos comentado, para las grandes empresas el coste de sus actividades de presión es insignificante comparado con el beneficio que obtienen. Además, la probabilidad de conseguir influir en las decisiones políticas es muy elevada, pues tradicionalmente lo logran. ¿Cómo lo consiguen? Mencionaremos a continuación algunos medios, pero al lector interesado le recomiendo que vea los documentales "El mundo según Monsanto" y "Inside Job" para obtener más información de forma amena.

Cabe resaltar que los lobbies de las grandes empresas cuentan con mucha financiación y un ejército de personas contratadas para influir en el Estado. Si no consiguen modificar una ley este año, ya lo intentarán el que viene o con el próximo Gobierno. No descansan ni desesperan. La constancia es una de sus características distintivas.

Pueden influir directamente conformando la ideología y las actuaciones de los partidos políticos a los que financian o incluyo pueden crear partidos políticos, si bien en estos casos procurarán mantener en silencio que el partido en cuestión ha sido creado por grandes empresas y multimillonarios para defender sus intereses.

Los lobbies también se presentan directamente o a través de asociaciones bajo su control, como fuente de información sectorial necesaria para el Estado, como expertos y técnicos apolíticos. Esta información es la que se tiene en consideración a la hora de legislar. En muchas ocasiones no se verifica la exactitud de la información suministrada ni se recurre a otras fuentes de información alternativas, especialmente cuando están en la misma línea ideológica que el Gobierno. Y es que a veces no son los grupos de presión los que buscan al Gobierno, sino que un Gobierno con una ideología específica 
puede dirigirse al lobby conveniente para que justifique una política concreta. $Y$ en no pocas ocasiones son miembros de la comunidad universitaria los que se prestan a realizar informes para los lobbies, de dudosa calidad científica, pero que defienden y alaban los postulados que benefician a éstos.

Los expertos al servicio de los grupos de presión, los informes que realizan, además de influir sobre el Estado, también pueden destinarse a influir sobre la opinión pública. Especialmente nocivas son las campañas de desinformación mediante las que se intenta manipular a los votantes, como ocurre constantemente con temas como el consumo de tabaco, el cambio climático o la regulación financiera. Otro efecto sumamente grave es que merced a estas campañas de manipulación se establece en la sociedad la frontera entre lo que es razonable, lo que es aceptable y lo que no. Se fijan los límites del debate. Se establecen unas "verdades" axiomáticas que nadie puede siquiera intentar refutar si no quiere ser tachado de loco revolucionario iletrado. Esta situación es especialmente aplicable en el campo de la economía política, es decir, en el tema de este ensayo.

Los grupos de presión que conforman las grandes empresas formal o informalmente disponen de numerosos instrumentos para influir en los políticos que toman las decisiones importantes. Por supuesto que existen los sobornos, pero hay medios mucho más sutiles, como contratar a amigos y familiares en empresas o fundaciones bajo el paraguas de las grandes empresas beneficiarias de favores más o menos concretos. Y a los propios políticos también los pueden contratar al acabar su periplo en el sector público. Es lo que se llaman las "puertas giratorias". Al contratar a un político jubilado, las empresas tienen acceso preferente a sus amistades y contactos que permanecen activos en el sector público y, adicionalmente, les están mandando un mensaje a éstos: si nos tratáis bien, también os cuidaremos bien a vosotros en el futuro. El concepto de "puertas giratorias" también abarca las situaciones en las que el Estado contrata para ejercer un cargo político de responsabilidad a una persona proveniente de una de las empresas que se verán afectadas por su actuación. En no pocas ocasiones, cuando acabe su "encargo" en el sector público, esta persona regresará a la empresa de origen. Cualquier ciudadano con el mínimo espíritu crítico puede sospechar que esta persona no será absolutamente neutral y que tenderá a favorecer a la empresa de donde procede y a la que volverá. 
Para terminar, podemos mencionar que, si los políticos no acceden a las exigencias de los grupos de presión "por las buenas", éstas disponen de un repertorio de persuasión más agresivo. Dado su poder mediático, directo o indirecto, pueden atacar al Gobierno, a partidos políticos o incluso políticos concretos para deteriorar su imagen pública, reducir el apoyo de los votantes y terminar con su carrera política. $\mathrm{Y}$, en no pocas ocasiones, lo pueden hacer difundiendo medias verdades, calumnias y bulos, pero sin que trascienda que ellos, los lobbies, están detrás de estas publicaciones mentirosas.

De hecho, una de las características más importantes de la actuación de los grupos de presión empresariales es su discreción. Para el ciudadano medio apenas existen. Por ejemplo, los lobbies desempeñan un papel fundamental en la redacción de acuerdos comerciales internacionales que tienen una gran repercusión en las políticas estatales, el reparto de la riqueza y en la propia soberanía de los Estados. Es decir, tienen un impacto muy directo en la vida de los ciudadanos. Pues bien, querido lector, ¿has oído hablar del Tratado Transatlántico de Comercio e Inversiones (TIPP) y el Tratado sobre la Carta de la Energía? Pregúntate por qué.

\subsection{LOS POLÍTICOS}

En principio, los políticos son las personas que toman las decisiones que atañen al funcionamiento del Estado buscando lo mejor para la ciudadanía. Aunque pensamos que los dirigentes políticos que ocupan cargos en las altas esferas del Estado gozan de mucho poder, lo cierto es que su campo de acción es bastante limitado en la realidad. No solo hay tensiones internas en el propio Estado o en los partidos políticos, sino que existen presiones externas muy poderosas, como la proveniente de los lobbies que acabamos de describir. Todos los políticos dicen querer lo mejor para la mayoría de los que ellos consideran ciudadanos, si bien eso no implica compartir las ideas expuestas en este libro en lo relativo al papel del sector público en la economía. 
Los políticos son los que ostentan el poder ejecutivo y el poder legislativo en los diferentes niveles territoriales (supranacional, nacional, regional, local). Son los representantes de los ciudadanos que definen, ejecutan y gestionan las políticas públicas. Pueden ser electos o no, pero dependen directa o indirectamente de cargos electos, ocupando puestos de libre designación en los escalafones más altos de la jerarquía burocrática, sin ser necesariamente burócratas. No permanecen muchos años en el mismo puesto y su poder deriva de los resultados de los diferentes procesos electorales.

En principio, los políticos buscan implementar honestamente su visión política social y económica, sea de signo social o neoliberal, para mejorar la calidad de vida de sus conciudadanos. Para ello deben ser elegidos por los votantes, por lo que uno de sus objetivos es el de contentar a los electores, al menos de palabra, pues, por desgracia, no es difícil comprobar que muchos políticos olvidan los intereses de las personas a las que representan. Como consecuencia, es posible que las medidas desagradables para el electorado se implementen al principio del mandato (aumento de impuestos, reducción de prestaciones y servicios públicos etc.), cuando falta mucho para el próximo periodo electoral, y que se incremente el gasto público en periodo preelectoral, que es también periodo de inauguraciones de obras públicas. Todo ello, para aumentar las posibilidades de reelección. No obstante, hay que resaltar que la situación macroeconómica muchas veces no permite esta planificación.

Junto con la satisfacción personal por ayudar a la colectividad e implementar su modelo social y económico, encontramos otros objetivos menos nobles que impulsan a los políticos, como enriquecerse, mejorar su status, la fama y el reconocimiento, el poder...

La actuación de los políticos puede generar graves fallos en el funcionamiento del Estado y la consecución de los objetivos que, en nuestra opinión, deben guiar la actuación estatal.

La dinámica política, el afán por tener un buen sueldo, o simplemente de vivir de la carrera política durante largo tiempo tienen como consecuencia grandes gastos en la estructura del Estado, pues proliferan organismos estatales cuya 
finalidad es servir de lugar de retiro a políticos que han visto decrecer su influencia. Además, es común que los políticos disfruten de ciertas prebendas y privilegios en comparación con el resto de ciudadanos, como ciertos complementos salariales, pensiones más elevadas, gastos pagados etc. Lógicamente, en este caso y todo lo que estamos comentando en este capítulo, la situación varía mucho entre países y momentos del tiempo.

Al margen de este sobrecoste dentro de la más estricta legalidad, los políticos generan ineficiencias cuando, pensando que están libres de todo control y no van a ser descubiertos, realizan acciones al borde de la legalidad o ilícitas para aumentar su nivel de vida y enriquecerse. Es el caso de la malversación de dinero público para obtener un beneficio personal directo. Seguro que al lector le vienen a la mente multitud de ejemplos. Para profundizar en toda esta temática y conocer cómo derrochan los políticos el dinero público, recomiendo la lectura del libro de Daniel Montero "La Casta, el increíble chollo de ser político en España".

No siempre el despilfarro se comete para beneficiar directamente al político. En muchas ocasiones el beneficiario es un lobby, que como acabamos de ver, recibe una subvención a un contrato público a cambio de ayudar al político a conseguir sus objetivos personales (dinero, ayuda para la reelección, puertas giratorias), en una relación simbiótica. Además, en muchas ocasiones el quebranto al Estado no se realiza al aumentar el gasto, sino disminuyendo los ingresos, por ejemplo, la recaudación de ciertos impuestos que gravan a ciertos colectivos influyentes, o con amnistías fiscales.

Estas acciones pueden estar amparadas por la ley. Si no lo están, hablamos de corrupción, e implica realizar un uso partidista del Estado para favorecer de forma ilegal a empresas afines, amigos y familiares. La corrupción es algo muy habitual en ciertos países, especialmente en aquellos en los que los políticos corruptos no son repudiados por la opinión pública y los votantes. Muchas actividades del Estado se pueden encontrar salpicadas por escándalos de corrupción y tienen un ingente coste para la colectividad, siendo además causa de colosales ineficiencias. Algunos de los ámbitos más fecundos para la actividad corrupta son la asignación de obra públicas y contratos públicos, las concesiones, la política urbanística, el gasto militar, subvenciones, recates 
públicos o las diversas formas de regular a favor de empresas de familiares y afines. A otro nivel, pero también utilizando el poder del Estado para favorecer a personas afines y generando ineficiencias, nos encontramos a los políticos que crean empleo público para colocar a sus familiares y compañeros de partido.

Uno de los casos más graves de actuación ilegal de los políticos es cuando utilizan el poder del Estado para espiar y perseguir a los partidos políticos de la oposición. En algunos países, como EEUU, eso es motivo de gran escándalo mediático y es castigado en las urnas por los electores, como ocurrió con el caso Watergate de Nixon. En otros países, como España, muy pocos medios se hacen eco de estos escándalos, por lo que pasan desapercibidos en la opinión pública, como el caso de la Cloacas del Estado. Estas actuaciones no solo implican un gasto adicional injustificable, sino que representan un ataque directo a la democracia y las Constituciones de los Estados. Recomiendo al lector que se informe acerca del caso español, que es increíblemente escandaloso.

Finalmente, vamos a destacar otro hecho que está relacionado con el uso ilegal del poder del Estado: la falta de control efectivo. Los políticos, para poder hacer y deshacer a su antojo, necesitan hallarse libres de controles. El control lo ejercen, como veremos, la burocracia, los votantes y los medios de comunicación. También el poder judicial, del que hablaremos a continuación. Bien, de todos ellos, el control más directo y continuo es el de la burocracia. En este contexto, no es de extrañar que los políticos corruptos tomen toda clase de medidas para eliminar el control por parte de los empleados públicos. Y que se persiga hasta la extenuación a los denunciantes de corrupción, utilizando para ello todo el poder del Estado. Esta situación es una vergüenza para los países en los que ocurre. $Y$ es muy significativa la nula cobertura que se da en los medios de comunicación a esta situación. Muy significativa. Al lector interesado le recomiendo que indague sobre la vida de Luis Gonzalo Segura, quien denunció la corrupción en el Ejército Español, o de Ana Garrido Ramos, quien destapó el caso Gürtel. Que el Estado utilice recursos para atacar a los que arriesgan su bienestar económico y psicológico para salvaguardar el bien común es una barbaridad injustificable. Salvo que lo que busquen los políticos no sea precisamente el bien común, sino una descarada redistribución de la riqueza, del erario público a sus bolsillos y los de sus afines. 
Dicho esto, limitarse a condenar la actuación de los políticos y generalizar su conducta es un error garrafal y una grave amenaza para la democracia. Por supuesto que hay que exigir a los políticos una conducta honesta, pero no podemos eliminar a los políticos, que son los representantes de los ciudadanos, elegidos más o menos directamente. En mi opinión, hay que fomentar la participación ciudadana, avanzar hacia una verdadera democracia y un control más directo de la actuación de los políticos. Pero, sin políticos, sin esas personas elegidas democráticamente que detentan el poder legislativo y ejecutivo, ¿quién toma las decisiones? En numerosas ocasiones se propone que, en lugar de los políticos, las decisiones importantes deben ser tomadas por autoridades independientes, expertos "apolíticos", tecnócratas que no están influidos por las opiniones de los votantes de los ciudadanos. En mi opinión, esta solución es muy peligrosa y daña el sistema democrático. Es cierto, y eso es problemático, que los tecnócratas no responden ante los ciudadanos, pero eso no significa que no sean inmunes a la influencia de otros grupos de presión, que tendrán entonces más fuerza. Se trata, simplemente, de autoridades "independientes" frente a los votantes. Baste como ejemplo la actuación del Banco Central Europeo, totalmente independiente, y su enorme responsabilidad en la creación y gestión de la crisis financiera de 2008 en Europa y sus consecuencias negativas sobre los ciudadanos europeos.

Dentro del Estado, al margen de los políticos, el Poder Judicial, los jueces, también pueden provocar fallos e ineficiencias en la actuación del Estado. En muchos países se encuentran totalmente liberados del control ciudadano y, al disfrutar de la lógica y necesaria independencia que conlleva su cargo, se pueden extralimitar en sus funciones o son parciales en sus decisiones. Los jueces, al igual que los políticos, son objeto de las actuaciones de los grupos de presión, de los que pueden recibir contraprestaciones dinerarias dentro de la legalidad, por ejemplo por impartir cursos y conferencias.

Además, debemos recordar que los jueces son, en primer lugar, personas. El hecho de que su profesión sea la de juez no hace que una persona deje de tener una ideología, aunque no milite en un partido político. En algunas ocasiones, los jueces en la cúspide del sistema judicial, quienes, además, son elegidos para el cargo precisamente por su ideología, tratan de imponer su manera de ver las 
cosas, su visión de la economía y la sociedad, mediante sus sentencias. Pierden la necesaria imparcialidad y toman partido a favor de los que consideran que defienden su cosmovisión, para lo cual realizan interpretaciones forzadas y sesgadas de los hechos y de la ley para proteger a los que la infringen, tanto a políticos como a empresas. También utilizan su cargo para atacar la actuación del Poder Ejecutivo o del Poder Legislativo si es contraria a su ideología.

Esta realidad es especialmente alarmante si, como hacemos en este libro, se es consciente de la importancia que tiene el control de la actuación del Estado y de las empresas, tanto por los ciudadanos como, en última instancia, por el Poder Judicial. Si el Poder Judicial abandona su posición neutral y toma partido por una de las partes, permitiendo actuaciones contrarias a la ley que, además, fomentan la concentración de poder económico y político y la preservación forzada del statu quo, la situación se torna muy seria y problemática.

\subsection{LA BUROCRACIA}

Cuando pensamos en la ineficiencia del sector público, la burocracia es, posiblemente, lo primero que nos viene a la cabeza. Siendo un problema grave, no es, en mi opinión, el mayor peligro para el correcto funcionamiento del sector público, pero sí que es el aspecto que cotidianamente más fastidia al ciudadano de a pie. Por eso, la burocracia es el más evidente de los problemas del Estado para la mayoría de nosotros. Al margen de los problemas para los administrados, el entramado burocrático constituye un poder anónimo que tira arena en los engranajes e impide cualquier cambio en la actuación estatal, para bien o para mal. Como en todo lo relativo al Estado, el poder de los burócratas depende de cada país.

Llamaremos burócratas a las personas que trabajan para el Estado en sus diferentes organismos y estructuras, si bien la cúspide jerárquica la suelen ocupar políticos, pues son puestos de confianza de libre designación.

La clase de los burócratas desempeña un papel fundamental en el Estado. Se caracteriza por la inercia y la resistencia al cambio. Como, obviamente, no actúa 
movida por los beneficios empresariales, tiene pocos incentivos para mejorar la productividad.

Cabe destacar que algunos de los problemas burocráticos y sus deficiencias no son exclusivas del sector público, sino que aparecen en todas las grandes organizaciones. Pensemos en los problemas que tenemos como clientes cuando tenemos que tratar con algunas empresas, especialmente grandes y con poca competencia real, y su burocracia (empresas telefónicas, aerolíneas, bancos, eléctricas...)

Los burócratas son servidores públicos y, como tal, su finalidad es ser el brazo ejecutor del Estado y sus políticas. Al margen de esta finalidad, los burócratas tienen otros objetivos particulares. Para un jefe de departamento, por ejemplo, lo importante puede ser mantener o acrecentar su cuota de poder, lo que implica aumentar su presupuesto, su tamaño o el número de personas a su cargo. A nivel particular, un objetivo puede ser minimizar el coste personal, el esfuerzo realizado, en el sentido de tiempo trabajado o intensidad del trabajo, así como el dedicado a la formación o evitar el esfuerzo ocasionado por cambios organizativos. Un empleado público con estos objetivos (por suerte, no todos los empleados públicos tienen esta forma de pensar) los podrá alcanzar o no en función del control que se ejerza por sus compañeros y superiores o del régimen sancionador que se pueda aplicar, que puede depender del tipo de relación contractual. Una relación contractual más flexible tiene una serie de ventajas innegables, pero también implica que la posición del empleado público es más débil y es más sumiso ante propuestas ilegales de sus superiores.

La burocracia influye negativamente en la eficiencia del Estado por numerosas vías. En no pocas ocasiones, el fin que se persigue es legítimo y positivo, pero la implementación resulta deficiente. Aquí vamos a comentar los problemas generados por la necesidad de control del gasto público para evitar actividades corruptas y el despilfarro, la actuación reprobable de algunos funcionarios, los procedimientos administrativos mal diseñados, la tendencia al crecimiento incontrolado y la aversión al cambio por parte de los burócratas. 
Gran parte de los problemas burocráticos se deben a la necesidad de controlar minuciosamente el gasto público para evitar la corrupción y la malversación de fondos. Así, existen numerosos controles en la gestión del personal o en la contratación de bienes y servicios. No obstante, este control no siempre logra su objetivo, pues se instrumentan nuevas vías para soslayarlo, y, sin embrago, sí que aumenta los costes y encorseta la actividad del sector público. Por ejemplo, la necesidad de elaborar y ejecutar los presupuestos anualmente dificulta la gestión en el caso de las inversiones a largo plazo. Se trata de una medida encaminada a limitar el poder de los políticos y funcionarios, en aras de la transparencia y la eficiencia, pero que a veces parece que es contraproducente. De hecho, existen diversos mecanismos para modificar los presupuestos, o simplemente no se ejecutan, o se gasta al margen de lo presupuestado.

Dentro de esta dinámica, las decisiones que se adoptan deben ser siempre justificadas, en beneficio de los administrados y de la transparencia. En caso de actuaciones erróneas, se puede reprobar la actuación del empleado público o del político. Esta situación genera unos protocolos cuyo seguimiento exonera a los funcionarios y a los políticos de toda responsabilidad. En numerosas ocasiones, estos protocolos se convierten en un mero ejercicio formal, papeleo absurdo para justificar las decisiones. El coste de este papeleo, en tiempo y dinero, no recae sobre los que lo han generado, sino sobre la sociedad en su conjunto, o sobre el ciudadano que se ve inmerso en el procedimiento administrativo.

Por otro lado, los controles burocráticos pueden llegar a paralizar la actuación de los políticos. $\mathrm{Y}$ es que, en ocasiones, los burócratas, obsesionados con el cumplimiento de la legalidad, realizan interpretaciones excesivamente restrictivas de la ley para evitar responsabilidades, impidiendo toda actuación. Así, la estructura del Estado se puede interpretar como una lucha constante entre los políticos, que desean realizar cambios, y los burócratas, empeñados en que nada cambie. La serie de televisión británica "Sí, Ministro", recoge esta perspectiva a la perfección.

En España, precisamente para evitar todas estas rigideces propias de la Administración Pública, se recurre en numerosas ocasiones a la creación de empresas públicas, que no tienen controles exhaustivos en la contratación del personal ni en sus sueldos, tienen libertad de contratación y están sujetas a poco 
control externo. El resultado ha sido que las actividades corruptas han visto un lugar donde establecerse, ocasionando grandes quebrantos al erario público. Allí donde no hay control, florece el derroche y la corrupción. Lo cierto es que es difícil mantener el equilibrio entre control y flexibilidad, pero no imposible.

Por otro lado, como ya hemos comentado, los políticos, cuando se perpetúan en el poder y se ven libres del control de los ciudadanos, los medios de comunicación y la Justicia, pueden presionar a los probos funcionarios y removerlos de sus puestos si no obedecen sus directrices y no permiten sus actuaciones corruptas, saltándose todos los controles. Incluso aunque las medidas tomadas contra los funcionarios sean ilegales, la lentitud de la Justicia hará que los funcionarios tengan que pasar por un calvario y el político pueda ejecutar sus planes. Además, en numerosas ocasiones, el propio Estado usa su poder para perseguir a los denunciantes de corrupción. Por otro lado, puede haber funcionarios colocados por los políticos precisamente para que aprueben sus actuaciones sin dilación. En estos casos la burocracia y los controles, necesarios o absurdos, permanecen para el ciudadano, pero desaparecen para aquellos que van de la mano de los políticos corruptos.

Pero no todos los problemas de la burocracia se deben al necesario control de la actividad del Estado. El propio comportamiento de los funcionarios se convierte en demasiadas ocasiones en una lacra. No todos se comportan como vamos a describir, lógicamente. Ya hemos comentado más arriba los objetivos de los empleados públicos y uno esos objetivos puede ser esforzarse lo mínimo posible o, dicho de otra forma, no preocuparse por la calidad del trabajo que se realiza, lo que genera errores que luego debe subsanar el administrado sin que se le indemnice por el tiempo y el dinero que debe gastar. En esta línea argumental podemos pensar en aquellos funcionarios que no cumplen su horario de trabajo, que nunca están disponibles, que maltratan al ciudadano de palabra y obra, maleducados. Son casos en los que el funcionario, un servidor público, ve al administrado como un estorbo, alguien al que hay que soportar, pero no percibe la conexión entre la obligación de atender al ciudadano y cobrar la nómina a fin de mes. Es cierto que en ocasiones esta falta de motivación se debe a causas ajenas al empleado público, pero eso no es excusa para maltratar al ciudadano. Por otra parte, estos comportamientos minan la moral del resto del 
personal, quienes, además, deben suplir sus funciones en no pocas ocasiones. El caso es que implementar sistemas que midan objetivamente el rendimiento de los funcionarios y su buen hacer es muy complejo, aunque sí es posible, y se encontrará con la oposición de los afectados y los sindicatos. $Y$ hay que tener en cuenta que la falta de sistemas de control de la actuación del personal público dificulta que se pueda sancionar a los que no actúan correctamente.

Al comportamiento de algunos empleados públicos hay que sumarle el diseño nefasto de unos procedimientos largos, requerimientos injustificados de documentación, problemas en la comunicación con los encargados de los expedientes o aplicaciones informáticas que no funcionan, por mencionar algunos problemas habituales. Es importante resaltar que todos estos problemas son caldo de cultivo para la corrupción. Si los procedimientos se alargan en el tiempo, cuando hay mucho dinero en juego, como en el negocio de la construcción, los empresarios tienen incentivos para sobornar al funcionario del Ayuntamiento para que acelere los trámites y ponga su expediente arriba del montón. Y no es justo culpar al empresario de este comportamiento.

Pensemos en cualquier ámbito de la actuación estatal: Policía, justicia, educación, sanidad, investigación... nos vendrán a la mente la falta de transparencia, los procedimientos administrativos absurdos, los canales de comunicación con la administración obsoletos, los procedimientos que permiten la discrecionalidad y generan indefensión etc. En este sentido, cabe destacar la dificultad de medir el rendimiento de muchas de las actividades del sector público, lo cual dificulta la lucha contra la ineficiencia. Pero dificultad no implica imposibilidad.

El sector público tiene una fuerte tendencia al crecimiento desmedido que es necesario controlar para evitar ineficiencias. Pero ese control no es fácil. Una vez que el número de empleados públicos es elevado, los burócratas constituyen un grupo de presión nada desdeñable dentro de los votantes. Además, el crecimiento del sector público es una forma rápida de crear empleo y conseguir nuevos votantes. Por otro lado, ya hemos comentado que la propia burocracia tiene como incentivo intrínseco crecer en términos de personal y en términos de presupuesto gestionado. Se trata de gastar cada vez más, cuando el objetivo 
debiera ser gastar menos y mejor. Se olvida que la contratación de un empleado público, si prescindir de los servicios de un empleado público es difícil, contratar a un funcionario adicional conlleva asumir un coste adicional durante muchos años y dotar a esa persona de tareas productivas durante todo ese tiempo. Esta situación complica mucho la introducción de mejoras tecnológicas en las tareas realizadas por el Estado que podrían aumentar su calidad pero que dejarían sin tareas efectivas o dejarían en evidencia a muchos funcionarios.

Y es que la inercia y el objetivo del sistema burocrático de defender su statu quo, pueden ser un problema de primera magnitud. Cualquier reforma en profundad en la Administración Pública requiere esfuerzos titánicos. La resistencia al cambio por parte de los empleados públicos es formidable. Esto hace que todos los cambios estructurales se queden en meras operaciones de maquillaje. Tampoco interesa a los burócratas implementar sistemas de control de costes ni de control de eficacia de las políticas públicas y su gasto directo en personal. Pensemos en las políticas activas de empleo, que, por cierto, son fuente recurrente de escándalo por su ineficiencia y focos de corrupción. Sería interesante analizar su eficiencia, su coste total, directo e indirecto, frente al número de personas que se han beneficiado de las mismas y han conseguido un empleo. Analizar las características de esas personas y de los empleos conseguidos. Se podría valorar así si merece la pena incurrir en ese gasto o si hay que cambiar de política, si se están mitigando realmente los fallos del mercado o éste puede hacerlo mejor, si hay mejores alternativas... Pero, ¿qué ocurre si la conclusión del análisis es que hay que desmantelar los Servicios Públicos de Empleo? ¿Y si implantar una renta básica es más eficiente que las prestaciones por desempleo? ¿Y si la formación de los desempleados se imparte en los institutos y las universidades? A la burocracia afectada no le interesa en absoluto realizar este tipo de análisis, no vaya a ser que los resultados sean demasiado reveladores y haya cambios. A la burocracia, así como a los políticos afectados y los grupos de presión, como los sindicatos, le interesa mantener esa infraestructura organizativa e incluso aumentar su coste, alegando que los resultados son malos porque no se dispone de medios. $Y$ en el caso de que se intenten realizar cambios, la estructura burocrática conseguirá frenarlos, por acción u omisión, hasta que el promotor de la idea sea defenestrado. 
En definitiva, la burocracia, si bien es necesaria, puede llegar a suponer un enorme coste directo e indirecto y es origen de diversas ineficiencias del sector público. Debe existir un equilibrio entre su actuación y los controles a los que está sujeta. Por otro lado, es necesario medir la eficiencia de esas actuaciones. Acometer cambios es muy complejo, pero éstos pasan por modificar las políticas de selección y gestión de personal, introducir controles de eficiencia y mejorar los procedimientos implementando realmente la administración electrónica. Todas estas medidas son fundamentales, pues en muchas ocasiones la percepción que tienen los ciudadanos de lo que hace el Estado por ellos se crea de sus interacciones con la Administración Pública y los burócratas que la forman.

\subsection{LOS VOTANTES}

Los fallos que los votantes causan en la actuación del Estado se deben principalmente a su visión cortoplacista y a su falta de participación en los asuntos públicos. Tradicionalmente la teoría económica les ha dado mucha importancia y ha desarrollado modelos basados en hipótesis irreales, como que los votantes son absolutamente racionales o que disponen de información perfecta.

Los votantes son aquellas personas con derecho a participar en las elecciones y referenda convocados por el Estado y, por lo tanto, eligen de forma directa o indirecta a los políticos que van a gestionar el poder estatal.

Según la teoría económica, los votantes, al igual que las empresas, buscan presionar hacia mayor gasto estatal sin subir impuestos, lo que genera ineficiencias. En realidad, podríamos matizar y decir que no buscan necesariamente mayor gasto público (excepto, tal vez, el destinado a las subvenciones directas que reciben ellos) sino más y mejores servicios públicos, que no es exactamente lo mismo y se puede conseguir, precisamente, con mayor 
eficiencia del sector público. Tampoco buscan necesariamente aumentar su consumo: aunque la educación primaria sea gratuita, ningún votante se inscribiría en un colegio. Lo que sí buscan es defender sus bienes y derechos. En general, buscan mejorar su calidad de vida. Muchas veces el verdadero problema es que, en un mundo complejo como el nuestro, es difícil saber qué políticas se deben implementar para alcanzar ese objetivo. Entonces resulta difícil discernir qué opción política realmente defiende nuestros intereses. Además, la gran mayoría de los votantes carece de los conocimientos necesarios para comprender los debates en diferentes materias, como la económica, y encuentra aburrido el debate donde se plantean las diversas propuestas alternativas. Muchos políticos aprovechan esta falta de interés y llevan el debate electoral al terreno de los sentimientos y convicciones de los votantes, aportando argumentos simplistas o falsos con los que contentar al electorado.

La actitud de los votantes puede generar diversas ineficiencias en la actuación del Estado. Por ejemplo, la necesidad de contentar al electorado puede inducir a los políticos a implementar políticas populares a corto plazo pero ineficientes y perjudiciales a medio y largo plazo. Estas medidas pueden ser de carácter macroeconómico, en el ámbito de la redistribución o en la asignación de recursos. Así, los votantes pueden criticar la actuación de un Gobierno que frene el crecimiento económico con el fin de evitar una crisis posterior, pueden proponer aranceles para defender una industria de la competencia extranjera o defender dar subvenciones a empresas ineficientes y obsoletas para mantener el empleo en una región. También pueden oponerse a actuaciones que afecten a sus pautas de consumo, aunque sean medidas propuestas desde estamentos científicos. Una vez que se crea una política concreta es difícil eliminarla sin la oposición más o menos firme de los beneficiarios de dicha política. Además, por lo general, contentar a los votantes impide realizar cambios estructurales de calado, aunque fueran positivos para la sociedad, pues muchos cambios pueden ser impopulares a corto plazo. $Y$ es que los votantes suelen pensar en su situación personal actual e inmediata, son cortoplacistas, y no ponderan cómo afectarán las políticas actuales a los ciudadanos futuros. 
A los votantes se les puede responsabilizar, además, de ciertas ineficiencias y fallos del Estado en tanto que no realizan un verdadero control sobre el Estado, siendo ésta una de sus principales funciones. Pero esta falta de interés no es responsabilidad única de los votantes. Son muchas las trabas que impiden a los ciudadanos participar activamente en los asuntos públicos en países como en España, como trato en el libro "Participación ciudadana, democracia y crisis económica". Por ejemplo, el sistema electoral, la falta de consultas directas (no como ocurre en otros países, como Suiza o EEUU), la escasa posibilidad de participar a nivel local, por ejemplo, mediante presupuestos participativos, la ausencia de interés por parte de los políticos por conocer su valoración de los servicios prestados por el sector público, algo relativamente fácil de implementar hoy en día, o la falta de transparencia desincentivan la cultura participativa. La sociedad civil, las asociaciones culturales, de vecinos, de consumidores y usuarios, las organizaciones no gubernamentales... todas ellas son fundamentales para estructurar la participación ciudadana en los asuntos públicos, como también lo son todos aquellos que, a título individual, recopilan, analizan y comparten por diversas vías información que permite evaluar las actuaciones del Estado a sus distintos niveles, o explican a sus conciudadanos interesados los principios económicos, legales y políticos fundamentales en los que se basa su sociedad. Así se crea una sociedad formada e informada capaz de controlar a los poderes públicos. Un ciudadano que participa de los asuntos públicos se informa y exige resultados. Pero, lógicamente ni los políticos ni los empleados públicos ni los grupos de presión quieren en muchos casos someterse a ese escrutinio.

Así las cosas, el poder de los votantes se restringe a depositar su voto en una urna cada cierto tiempo. Entonces, su poder desaparece hasta las siguientes elecciones. Aunque no lo parezca, el coste de votar de forma informada es relativamente elevado. Requiere documentarse y conocer los programas de los distintos partidos, lo que, a su vez, exige cierto nivel de formación. $Y$, dado que los programas no son vinculantes, el votante debe intentar dilucidar si el partido político piensa o no implementar efectivamente lo que defiende en su programa. Por otro lado, los grupos de presión, a través de los medios de comunicación, 
pueden intentar manipular a la opinión pública a favor o en contra de un candidato, por lo que es importante estar alerta frente a estas actuaciones.

El mismo hecho de acudir a las urnas implica un coste de tiempo. El coste se percibe relativamente alto, pues hay poca probabilidad de que mi voto particular influya en los resultados y el beneficio que puedo obtener si gana la opción que yo he elegido es muy incierto. A esta situación hay que añadir los intentos por parte de algunos sectores por desincentivar el voto de los ciudadanos, con lemas tales como "todos los políticos son iguales". El resultado es la desafección de muchos ciudadanos y que otros muchos voten por opciones políticas que en realidad son contrarias a sus propios intereses.

Al margen de los periodos electorales, los votantes tienen poco poder. Apenas tienen capacidad de movilización para realizar campañas de presión al Gobierno o convocar manifestaciones, salvo excepciones puntuales por causas muy concretas.

Vemos pues cómo el teórico controlador del poder Estatal, el votante, tiene un poder más bien reducido y puede convertirse en un mero muñeco a merced de los medios de comunicación, objeto de su manipulación, como demuestra el auge de los populismos de extrema derecha a lo largo de la historia y en el momento actual. A este respecto, decir que entiendo por populistas a los discursos y partidos políticos que manipulan y simplifican los problemas complejos que afectan a una sociedad hasta el punto de identificar a unos pocos culpables. Esos pocos culpables, que pueden ser otras formaciones políticas, y, especialmente, grupos minoritarios, marginados e indefensos, son los causantes de todos los males de la sociedad. Eso es ser populista. Para mí, un partido político que no falsea la realidad y aspira a representar a la mayor parte de los ciudadanos y defiende una política que beneficie a la mayoría de los votantes no es un partido populista, sino un partido democrático. 


\subsection{LOS MEDIOS DE COMUNICACIÓN}

A los medios de comunicación se les denomina "el cuarto poder" en las democracias, junto con los poderes Ejecutivo, Legislativo y Judicial, dada la importancia que tienen en la tarea de controlar a los poderes del Estado. En las dictaduras, precisamente por su capacidad de influir en los ciudadanos, están completamente sometidas al poder estatal.

Los medios de comunicación tradicionales, a saber, prensa, radio y televisión, juntamente con las redes sociales y los medios en internet, pueden prestar un enorme servicio a las democracias publicando información pertinente de interés político, formando a los ciudadanos, controlando la actuación estatal y siendo un medio para ejercer la libertad de expresión. Pero también pueden convertirse en un instrumento en manos de la oligarquía dominante. $Y$ es que las grandes empresas y los lobbies pueden llegar a determinar la política editorial de los grandes medios de comunicación de masas. De hecho, los grandes medios de comunicación pertenecen a conglomerados empresariales multinacionales, que pueden utilizarlos para difundir sus puntos de vista económicos y políticos. Por otra parte, son empresas que obtienen la mayor parte de los ingresos de la publicidad, por lo que las empresas que se publicitan también pueden llegar a influir en el contenido editorial. Por su parte, el Estado también puede financiar a los medios de comunicación con publicidad institucional o con subvenciones. Por lo general, existen medios de comunicación propiedad del Estado, en cuyo caso existe el peligro de que adopten una política editorial partidita y sesgada a favor de una ideología y contra los adversarios políticos del partido gobernante.

La finalidad de los medios de comunicación, como empresas que son, es obtener beneficios. Además, desempeñan una función social, al ser un instrumento de información y de control a los políticos y al Estado. Pero también pueden servir para difundir un ideario político, económico y social, actuando al servicio de los lobbies o del Gobierno con la intención de influir en los votantes

Así, los medios de comunicación pueden informar, pero también desinformar. Su influencia en su público puede ser determinante en la interrelación entre los 
grupos de presión, los políticos y los votantes. Por ejemplo, pueden hacer aflorar escándalos de corrupción o puede silenciarlos de forma que muchos ciudadanos jamás conozcan su existencia. De esta manera influyen en la percepción de los votantes, por ejemplo, frente a casos de corrupción, dándoles mayor o menor importancia. También pueden emprender campañas difamatorias contra personas de ideología contraria o expandir bulos. Aunque luego sean condenados por difamación, el daño a la ciudadanía ya está hecho y es imposible revertirlo. En general, pueden manipular la opinión pública, justificar comportamientos antisociales y delictivos, presionar a los políticos y favorecer a empresas o personas o partidos políticos afines.

Su poder es tal, que los conglomerados financieros mantienen la propiedad de estas empresas aunque tengan pérdidas, pues reconocen el beneficio indirecto que obtienen por el control de la opinión pública. De ahí la importancia de que haya pluralidad en los medios de comunicación, de que no haya concentración de mercado, de que unos pocos medios no tengan una elevada cuota de mercado y de que los medios no pertenezcan a los mismos propietarios. Dado que, como hemos dicho, los grandes medios de comunicación son empresas y suelen estar controladas por accionistas que defienden una visión económica y una actuación del Estado específica que defienda sus intereses particulares, la intervención del Estado en el mercado televisivo está justificada. De hecho interviene, por ejemplo, participando directamente en él, como ocurre en muchos países que tienen empresa de televisión pública. No solo porque la información veraz es un bien público, sino porque se trata de un mercado muy imperfecto.

Para concluir este capítulo, recordemos que la intervención del Estado en la economía, en mayor o menor medida, es una cuestión generalmente aceptada. Pero el que el Estado deba actuar no implica necesariamente que lo vaya a hacer correctamente. En primer lugar, habría que definir qué significa "correctamente". Muchos partidos políticos proclaman que buscan mejorar la calidad de vida de la mayoría de ciudadanos en términos económicos, de derechos y libertades. Pues bien, como sabemos, los Estados, en no pocas ocasiones, se desvían de ese 
fin. Estas desviaciones, estos fallos en la actuación del Estado, se deben a la actuación de diversos actores: grupos de presión, políticos, burocracia, votantes y medios de comunicación, fundamentalmente.

Es muy probable que al pensar en la ineficiencia del Estado pensemos instantáneamente en la burocracia, sus inconvenientes y sus costes elevados. Siendo un gran problema, desde mi punto de vista no es el más importante, no es el problema número uno. Ese puesto de honor les corresponde a los grupos de presión, a los lobbies, empresariales. La actuación de los lobbies influye en el comportamiento de los políticos, de los medios de comunicación y de los votantes. Influye en las políticas monetaria y fiscal, en las políticas redistributivas, en las políticas de asignación de recursos. Influye en el funcionamiento de la democracia y tiene capacidad de doblegar la actuación de los poderes legislativo, ejecutivo y judicial. Frente a las ineficiencias burocráticas, de las que los ciudadanos somos muy conscientes porque las sufrimos diariamente, las ineficiencias generadas por los grupos de presión empresariales nos pasan inadvertidas. No hay ninguna cara a la que culpar, son anónimas, no hay un coste personal inmediato cuantificable, son imperceptibles. Generalmente, los medios de comunicación silencian todas las actuaciones de los grupos de presión, los beneficios directos o indirectos que obtienen, o les dan un tratamiento informativo muy superficial. Tal es el caso, que la mayor parte de los ciudadanos no es consciente del poder que tienen y cómo lo están ejerciendo constantemente. Cuando el poder de los lobbies empresariales aumenta, el statu quo se refuerza, el poder económico y político se concentra aún más, se multiplican los fallos en la actuación del Estado y la corrupción, aumentan las desigualdades y el sistema económico en su conjunto se vuelve más ineficiente. El propio sistema democrático puede llegar a peligrar. 


\section{MIRANDO AL FUTURO}

Decidir cuál es el papel del Estado en la economía es un tema polémico pero necesario que se ha discutido especialmente desde el siglo XVII. Ese papel obedece, por un lado, al objetivo que persiga el Estado. Por otro lado, depende de la situación económica, social y tecnológica del momento. Es decir, de los problemas que deba afrontar el Estado para lograr su cometido y de los medios de los que disponga.

Según se viene repitiendo a lo largo de este ensayo, en mi opinión, el papel del Estado en la economía es ofrecer un entorno social y económico que permita que las personas se puedan desarrollar como tales, buscar su plenitud personal y tratar de ser felices. Este objetivo no tiene por qué ser compartido por el lector, obviamente. Pero, para tratar el tema del papel del Estado en la economía es imprescindible definir el objetivo que se persigue. No se puede responder la pregunta sin explicitar el fin de dicha intervención.

Nada de lo que se ha explicado hasta el momento es nuevo ni original. Tampoco lo que comentaré en este último capítulo. Las teorías que tratan la problemática de la intervención estatal en la economía han sido ya desarrolladas por personas muy capaces, tanto las que defienden un tipo de intervención como otro. Yo, a lo largo de este ensayo, he venido defendiendo un tipo específico de intervención estatal en la economía basado en el fomento de los mercados de competencia perfecta, la eliminación de los problemas que generan estos mercados (como las externalidades, la inestabilidad económica, la desigualdad en la distribución de la renta o la concentración de poder económico) y la actuación del Estado cuando no hay competencia perfecta o no puede haberla. Se trata, por lo tanto, de una economía de mercado con una intervención del Estado relativamente elevada en la que el control ciudadano es fundamental. Pero, insisto, no hay nada de novedoso en esta opinión.

Los argumentos empleados en el libro para justificar la intervención o la inacción del Estado en la economía son muy útiles en cualquier contexto social, económico y tecnológico y es por eso que deben ser tenidos en consideración 
cuando se analice el papel del Estado en el futuro cercano, cuando este contexto sufra cambios sustanciales.

Para finalizar este ensayo vamos a repasar los retos principales a los que se ha enfrentado el Estado a lo largo de la historia hasta el presente y cuál ha sido su actuación. Después nos centraremos en algunos cambios de gran calado que van a tener un fuerte impacto en nuestras sociedades y que exigirán un cambio de paradigma en la forma de actuación de los Estados.

\subsection{SOBRE EL CRECIMIENTO ECONÓMICO}

Para valorar la actuación del Estado en la economía es necesario definir previamente qué objetivo debe alcanzarse. Para nosotros, el objetivo es generar un contexto económico y social que garantice un bienestar básico a los habitantes del Estado, en términos no solo materiales sino también de derechos y libertades, que permita el pleno desarrollo de la personalidad. Aunque me voy a centrar en los aspectos económicos, es fundamental recordar la necesidad de garantizar unos derechos y libertades básicos. Además, el propio desarrollo económico influye en esos derechos y libertades, que suelen verse cercenados en los Estados con gran concentración de poder económico y político. Y es que ambas clases de poder van casi siempre de la mano. En este contexto, hay que evitar a toda costa sistemas políticos absolutistas, dictatoriales o autoritarios incluso si garantizan cierto nivel de bienestar económico.

Desde el punto de vista del bienestar, lo más esencial que necesitan las personas es agua, comida, vestido y vivienda. Es decir, lo más básico que debe garantizar un Estado es el acceso de la población a estos bienes. Cómo hacerlo de la forma más eficiente es lo que hemos expuesto a lo largo de esta obra. Una vez se tiene lo necesario para sobrevivir, van surgiendo nuevas necesidades, más o menos acuciantes, como la seguridad personal, la salud o el acceso a fuentes de energía, que también son necesidades de primer orden. Todas estas necesidades se pueden satisfacer o no dependiendo del contexto social y 
tecnológico. Por ejemplo, lo más básico es el agua y la comida. El ser humano no sobrevive muchos días sin comer. Pues bien, el que se tenga garantizado el suministro de comida, como es el caso en los países europeos, es algo relativamente reciente. La producción de comida está sujeta a factores externos como el clima o las plagas, por lo que durante la mayor parte de la historia de la humanidad ha habido hambrunas. Y las sigue habiendo, por desgracia. De todo ello podemos concluir que para garantizar el suministro de comida, que es la primera función del Estado, es necesario tener capacidad productiva, que dependerá de factores naturales (suelo y el clima) y de la tecnología disponible (abonos y fertilizantes, insecticidas, variedades hortofrutícolas etc.), y asegurarse de que todas las personas tienen acceso a esa producción para satisfacer sus necesidades. Otra opción es importar la comida, en cuyo caso el abastecimiento del Estado puede verse amenazado si los países exportadores paralizan ese comercio. Actualmente, la falta de soberanía alimentaria no tiene por qué ser un problema, pero esta situación no es inmutable.

Producción y distribución. Estas son las actividades que debe garantizar el Estado, aunque haciendo un rápido repaso a la historia veremos que claramente se ha primado el aumento de la producción. De hecho, el aumento del PIB sigue siendo hoy en día una prioridad, pero no hay ningún objetivo relacionado con la distribución de la riqueza. Esto se debe a razones ideológicas, pues a los que detentan el poder les favorece personalmente aumentar la producción, pero redistribuirla ya no les viene tan bien. En este sentido, se dio gran publicidad a la famosa curva de Kuznets, que predica que para que aumente el PIB debe primero crecer la desigualdad y que, más tarde, habrá un efecto "desbordamiento", por el cual la riqueza "caerá" de los ricos a las otras capas sociales. Obvia decir que este proceso no es lo que ocurre en la realidad. El caso es que el foco de la actividad del Estado en la economía ha sido siempre potenciar el crecimiento, facilitar que la "tarta" sea lo más grande posible. Más tarde, en algunos países, ha intervenido también de forma muy decidida para aumentar la distribución de esta riqueza.

Esta actuación del Estado no es en absoluto reprobable, dadas las circunstancias pasadas. La situación material de las personas a lo largo de casi toda la historia de la humanidad ha sido bastante penosa. Incluso la de los más poderosos. También ellos sufrían de piojos y veían cómo sus hijos morían por 
enfermedades que actualmente no suponen ningún riesgo. En este contexto, lo fundamental era mejorar la producción. Producir más comida, más energía, más productos. Más avances médicos. Sin más producción era imposible garantizar un mínimo de subsistencia a la población. Los sistemas de la antigüedad basados en los esclavos y los posteriores basados en las relaciones feudales no consiguieron avances en el aumento de la producción ni progresos tecnológicos significativos.

En Europa, solo a partir del SXVII acontecieron los primeros cambios necesarios que permitieron acabar con el sistema feudal en algunos países. Llegó la primera revolución industrial. Apareció una nueva clase social, la burguesía y con ella cambió el reparto del poder político y económico en el siglo XVIII. Más tarde surgió el sistema capitalista y la segunda revolución industria en el siglo XIX. Fueron todos estos cambios sociales los que impulsaron la innovación y el progreso tecnológico que permitieron aumentar la productividad y la producción de forma espectacular. El sistema capitalista ha sido, sin lugar a duda, el responsable del nivel de vida que disfrutamos en la actualidad.

Ese sistema capitalista, no obstante, no era perfecto y, ya en el siglo XX se vio que la intervención del Estado era necesaria para regular la actividad empresarial y participar en algunos mercados. Después de la Segunda Guerra Mundial el bienestar material de gran parte de la población europea era bastante precario y la actuación del Estado en EEUU y los países de Europa Occidental se centró en el aumento de la producción de bienes y servicios a través de la economía de libre mercado, pero con una decidida actuación estatal en sectores que se consideraba estratégicos. Las políticas de redistribución surgieron en el tapete político y apareció el "Estado del Bienestar", que se sustentaba, no lo olvidemos, en el crecimiento continuo de la economía. Y así apareció la economía basada en la producción continua y creciente, necesitada de un consumismo voraz y ciudadanos con capacidad económica suficiente. En muchos países se alcanzó el pleno empleo a pesar de una población activa cada vez mayor. La población, en términos generales, gozaba de un nivel de vida muy aceptable y el consumo de las clases trabajadoras impulsaba el crecimiento económico. Desde entonces, las políticas económicas del Estado buscan aumentar el PIB a toda costa y suelen basarse en modelos en los que hay pleno empleo de los factores, como la mano de obra. Así, incluso hoy en día, el pleno empleo es un objetivo 
de muchos Estados, aunque tiene un rango jerárquico francamente inferior al objetivo de crecimiento del PIB. Se supone que el aumento del PIB generará empleo de calidad y se producirá el efecto descrito por Kuznets.

Con la crisis económica de los '70, la participación del Estado en la economía se puso en duda. A partir de la década de 1980 el nivel de intervención de los Estados en la economía ha descendido drásticamente en cuanto a las políticas de asignación de recursos, como la regulación del mercado y la política industrial. También la intervención del Estado en la política distributiva descendió, es decir, de la influencia del Estado en cómo se reparte la "tarta" entre trabajadores y capitalistas. Una de las consecuencias de estas políticas es el aumento incesante de las desigualdades entre los más ricos y el resto de la sociedad. En muchos Estados el desempleo, el subempleo y el empleo precario aumentan, lo que reduce el poder adquisitivo de los consumidores. Con la excusa de paliar este problema y evitar que el menor consumo ralentizara el crecimiento de la economía, se favoreció un crecimiento descontrolado del sistema financiero, que ha acabado por desligarse completamente de su función principal que es facilitar crédito a empresas y consumidores. Gracias al incremento de la deuda se ha conseguido mantener el consumo de las familias y las inversiones de las empresas durante un tiempo que no es indefinido pero, a cambio, se ha creado un sistema financiero muy inestable y unas dinámicas empresariales nefastas en su relación con los mercados de capitales. Para acabar de describir el panorama, el Estado está implementando políticas de corte neomercantilista, es decir, que favorecen a empresas concretas, que reciben un trato privilegiado, destruyen la competencia, fomentan la concentración de poder y aumentan las desigualdades sociales.

Pese a los muchos cambios habidos a lo largo desde Adam Smith, el objetivo del crecimiento perpetuo y acelerado de la economía se ha mantenido invariable.

El contexto social, tecnológico y medioambiental ha variado mucho en los últimos 300 años pero el objetivo económico principal de los Estados se mantiene imperturbable: crecer, crecer, crecer. $Y$, en esta dinámica de crecimiento, se olvida la importancia de la redistribución, necesaria para que todos tengan lo suficiente como para satisfacer las necesidades más básicas. Además, algunas cuestiones muy relevantes ni se plantean. 
¿Sigue teniendo sentido que la producción de bienes y servicios crezcan imparable? Obviamente, en muchos Estados donde no producen ni la comida que necesitan sí que es necesario fomentar el crecimiento. Pero, ¿y en los Estados industrializados, como los EEUU y los Estados europeos, por ejemplo? ¿Realmente es necesario incrementar nuestro nivel de vida a cualquier precio? Tal vez la tarta ya sea lo suficientemente grande en estos países y se puedan cubrir con creces las necesidades básicas y muchas más. Tal vez muchas de las necesidades accesorias se deben a la sociedad consumista que se ha creado, pero que no son, ni de lejos, necesarias para ser feliz. Por ejemplo, en la década de 1980 viajar por Europa era muchísimo más caro, por no hablar de ir a otro continente, así que muchos no podíamos permitírnoslo. Sin embargo, esta contrariedad no hacía que nos sintiéramos desgraciados. Al fin y al cabo, era lo normal. Tal vez ahora demos por normales pautas de consumo que no debieran serlo. Esto no es necesariamente culpa de los consumidores, pues vivimos en un mundo lleno de estímulos publicitarios que crean nuevas necesidades y nos incitan al consumo de productos que jamás antes habíamos echado en falta. Somos objeto de toda clase de manipulaciones que hacen que mayor consumo y más propiedades signifiquen mayor felicidad y autorrealización. No se trata ya tan solo de consumir y poseer, sino que es necesario que todo el mundo sepa lo feliz que soy gracias a todo lo que puedo comprar y todas las actividades exclusivas que puedo realizar. La sociedad promueve el hedonismo. Por otro lado, si el consumidor puede permitirse un capricho, ¿por qué no debería hacerlo? La culpa de que muchas personas se vaya de viaje a menudo, incluso a las antípodas y, para que puedan hacerlo, muchos aviones surquen los cielos contaminando alegremente, no es en absoluto de los consumidores, sino de los precios, que no recogen las externalidades negativas de dichos viajes. Es decir, la culpa es de las imperfecciones de los mercados, y no son los consumidores quienes tienen que corregirlos con un comportamiento más austero. Si se internalizan los costes de la contaminación, subirán los precios de los billetes y el número de vuelos disminuirá.

El aumento imparable del consumo es inherente a una economía capitalista o neomercantilista en la que las empresas buscan a toda costa maximizar sus beneficios. Esta actitud, que a nivel individual no es reprobable ni inmoral, siempre y cuando se respeten los derechos humanos, trae consigo graves 
problemas sociales y medioambientales cuando el Estado no interviene correctamente en los mercados, como en el ejemplo que acabamos de comentar, al hablar de los vuelos en avión. Actualmente, en realidad desde hace ya varias décadas, el nivel de consumo de EEUU y de muchos países de Europa es insostenible, en el sentido de que si los demás países del mundo intentan alcanzarlo, el planeta colapsará. Es un nivel de consumo ineficiente que se sostiene porque las externalidades negativas no se internalizan en forma de un mayor coste de producción.

El consumismo en sí no es malo, salvo por los problemas psicológicos que pueda causar. Pero, desde el punto de vista económico, que es lo que tratamos en este ensayo, es absolutamente ineficiente. Implica un uso desastroso de los recursos, por lo que hay que combatirlo si realmente buscamos la eficiencia. El derroche de recursos que ocasiona la economía de consumo es brutal. Además, gran parte de ese consumo se debe a los precios muy bajos a los que pueden vender sus productos las empresas que no asumen el coste de las externalidades que generan, como la contaminación de acuíferos o la emisión de gases de efecto invernadero.

Para abaratar costes, muchos productos viajan de un continente a otro hasta llegar a su destino final. Otros productos están diseñados para que tengan un solo uso, otros se diseñan exprofeso para que tengan una vida útil corta, como por ejemplo, cuando se da la obsolescencia programada. Aunque los productos tengan una vida útil más larga, también nos animan a cambiarlos, como en el caso de los teléfonos móviles. Tenemos que cambiar la ropa del armario cada dos o tres años... Una visión interesante las consecuencias del consumismo se puede obtener del documental "Comprar, Tirar, Comprar". En él se ponen de manifiesto diferentes ineficiencias, algunas de ellas provocadas a propósito para aumentar los beneficios empresariales. El sistema es tan ineficiente que consume recursos a gran escala que se pierden para siempre, que no se reutilizan ni se reciclan. Se trata de una forma de proceder absolutamente indefendible desde el punto de vista de una economía que se desarrolla en un planeta limitado, con recursos también limitados. Toda la basura que se genera diariamente es una muestra palpable de ineficiencia desbocada. Se crea un producto, con el consumo energético y de materias primas que conlleva, para que al poco tiempo acabe en el basurero. Como se suele decir, antes estas cosas 
no pasaban. Y es cierto, hasta hace poco tiempo los residuos domésticos eran todos biodegradables. Efectivamente, al margen de la ineficiencia en el empleo de los recursos no renovables, en el sentido de que desaparecen, el otro problema grave que trae consigo un consumismo desbocado es su impacto negativo en el medioambiente, desde el proceso productivo hasta que los productos se tiran a la basura y se acumulan en vertederos, como saben muy bien los expertos en economía circular.

Estas pautas de producción y consumo, este despilfarro de recursos, este deterioro del medio natural es totalmente insostenible. $Y$ se tienen que modificar cuanto antes. El caso es que los Estados son corresponsables de esta situación, en su afán de promover el crecimiento económico a cualquier precio. Un crecimiento medido a través de un indicador, el PIB, que no distingue correctamente entre lo que es creación de riqueza y extracción de riqueza (por ejemplo, esquilmar hasta su desaparición los bancos de peces), que no considera las externalidades negativas, que no distingue entre plantar un bosque en una zona con riesgo de desertificación a plantarlo porque previamente se ha quemado (en un caso habrá más bosque y, en el otro, la situación solo se mantiene como estaba, en el mejor de los casos). Se han estado explotando y diezmando recursos (de manera muy eficiente, eso sí) que ya no estarán disponibles para generaciones futuras, para alimentar una economía despilfarradora, ineficiente e irresponsable. El papel del Estado, según lo defendido en este libro, era defender la existencia de mercados eficientes, donde las externalidades negativas fueran internalizadas por las empresas y consumidores. Así hubiera disminuido la producción y se hubieran incentivado nuevas formas para satisfacer las necesidades de los consumidores. No se hizo. En su lugar se ha primado el crecimiento económico que, en las tres últimas décadas, ha favorecido especialmente a los grandes patrimonios y ha generado en algunos países industrializados un aumento de la desigualdad sin precedentes desde la Segunda Guerra Mundial.

El foco de atención no tendría que haberse puesto en maximizar el PIB y la creación de empleo aún a costa de destruir el medioambiente, sino en el desarrollo sostenible, aquel que satisface las necesidades del presente sin comprometer la capacidad de las generaciones futuras de satisfacer las suyas. 
Como consecuencia de esta actuación, la humanidad en su conjunto, no solo las economías que se han beneficiado de esta actividad económica, se enfrenta a graves problemas en el futuro. Por un lado, se acaba la era de la energía barata. Por otro lado, la emisión de gases de efecto invernadero, como el $\mathrm{CO} 2$ y el metano, por culpa de la actividad económica humana están provocando un cambio climático cuyas consecuencias se prevén desastrosas.

En definitiva, se está acabando el tiempo en el que el crecimiento del PIB era el objetivo económico número uno de los Estados y el empleo era el centro de las políticas de redistribución y asignación de recursos.

\subsection{EL FIN DE UNA ERA}

Cuando pensamos en la actuación de los Estados, los fallos y las posibilidades de mejora, inmediatamente acuden a nuestra mente innumerables cambios que es necesario afrontar. Por desgracia, hay mucho margen de mejora. Por ejemplo, resulta imprescindible luchar contra la corrupción y el despilfarro, evitar la evasión de impuestos, aumentar la transparencia de la actividad estatal y controlar las acciones discrecionales de los políticos, potenciar la participación ciudadana en los asuntos públicos, la denominada "sociedad civil", dando formación e información, es fundamental instaurar la administración electrónica, simplificar los procedimientos... Por no hablar de reformas en políticas específicas como la política monetaria o la política fiscal o la política de redistribución o cambios en sectores específicos como la sanidad, la educación o la defensa. Abordar un análisis detallado de todos los problemas y posibles soluciones va más allá del objetivo de este ensayo, si bien algunos de ellos sí se han comentado a lo largo del libro. En todos los casos se trata de problemas que, de alguna manera, aquejan al Estado desde hace muchas décadas.

A continuación, y para terminar este ensayo sobre el papel del Estado en la economía, vamos a presentar dos problemas relativamente nuevos y de gran envergadura que van a determinar la actuación de los Estados en las próximas décadas: la crisis energética y de materias primas, y el cambio climático. A causa 
de estas amenazas, y también al posible empleo masivo de robots, que ya se ha comentado a lo largo del libro, se van a producir cambios muy profundos en nuestras sociedades en muy poco tiempo. Cambios que nos van a obligar a repensar el papel del Estado en la economía y que van a afectas a todas las políticas: monetaria y fiscal, redistribución y asignación de recursos.

Estos cambios van a tambalear la estructura socioeconómica desde sus cimientos y pueden producir cambios en el statu quo. Empresas y sectores que hasta hoy han sido importantes, dejarán de serlo de la noche a la mañana. Personas influyentes hoy puede que dejen de serlo pronto y no puedan seguir viviendo de subvenciones estatales. Incluso economías enteras, países enteros van a presenciar cómo su poderío económico declina.

Ante estas perspectivas, es normal que quienes ven peligrar su posición de privilegio reaccionen y adopten todas las medidas a su alcance, desde negar la realidad y acusar de catastrofistas a quienes advierten de los peligros, hasta demonizar a aquellos que intentan acometer los cambios necesarios para minimizar las consecuencias negativas. El periodo de crisis profunda que se avecina puede favorecer el auge de partidos nazis o fascistas de extrema derecha que, como ya ocurrió en la década de 1930, bajo la apariencia de defender los intereses de la clase trabajadora, en realidad sirven a las grandes fortunas y no dudan en recortar derechos y libertades a los ciudadanos. Pido al lector que esté atento a esta más que posible evolución y que esté en guardia frente a discursos populistas que señalan a la clase política como culpable de todos los males. No seré yo quien diga que los políticos son espíritus puros, pero atacar a la clase política en general es atacar la democracia y promover sistemas políticos autoritarios, con el culto al líder y toda la parafernalia.

\subsubsection{LA CRISIS ENERGÉTICA Y DE MATERIAS PRIMAS}

Es muy posible que en breve nos enfrentemos a un problema de escasez de materias primas y recursos energéticos. No se trata solo de una crisis del petróleo, sino que le seguirán otros recursos como el gas o el uranio. En principio, era de suponer que algo así iba a pasar tarde o temprano, pues la tierra es finita y sus recursos no son infinitos. Los recursos más fáciles de extraer, las minas más fáciles de explotar, las más rentables, ya están agotadas. La 
búsqueda de nuevos pozos de petróleo es cada vez más incierta y la extracción, transporte y refino más caro. Sin la energía necesaria, la máquina económica se parará. Debemos ser conscientes de que el gran crecimiento económico del siglo XX se fundamenta en el consumo de petróleo barato. Sin esa energía, la producción descenderá y los precios subirán. Como casi la totalidad de los transportes funciona con derivados del petróleo, los costes de transporte se dispararán y el comercio internacional se verá resentido. Traer un contenedor en barco desde China dejará de ser barato. Además, el plástico es un derivado del petróleo. Intente el lector imaginar un mundo en el que el plástico sea caro. Pero no solo habrá escasez de plástico, sino de otras materias primas necesarias para fabricar productos de alta tecnología, como baterías para coches eléctricos, placas solares o microchips. Vaya panorama negro. Pensemos que para que suban los precios no es necesario que las materias primas se agoten, basta con que baje la oferta. Entonces los precios subirán y la demanda bajará, salvo que la demanda del bien sea muy inelástica por ser de primera necesidad, en cuyo caso los precios se dispararán. Estos precios elevados impulsarán la búsqueda de productos sustitutivos, de otras formas alternativas de satisfacer las necesidades humanas. Por ejemplo, mediante el uso de energías renovables. Pero, ¿existe actualmente esa alternativa? ¿Es posible suplir la energía que obtenemos del petróleo con energía renovable? La respuesta es negativa. Es posible que esté siendo catastrofista y no soy experto en el tema. Al lector interesado, le recomiendo seguir el bloc de internet de Antonio Turiel "the oil crash"(crashoil.blogspot.com) y leer su libro "Petrocalipsis".

El caso es que muy probablemente nos enfrentemos a un periodo de decrecimiento económico en términos de PIB. El crecimiento infinito del PIB, tal y como lo medimos, dejará de ser un objetivo político alcanzable. Y va a ser muy importante que los Estados actúen para dirigir el aterrizaje, que será suave o forzoso en función de su actuación. La situación final no tiene por qué ser necesariamente peor que la actual, a la vista del enorme despilfarro de recursos en muchas economías avanzadas. Se puede conseguir más bienestar con menos recursos usando mejor tecnología y más redistribución. Pero los cambios, insisto, pueden ser muy grandes y los Estados deben estar preparados. 
¿Qué puede hacer el Estado en este contexto? En líneas globales, lo que se viene comentando a lo largo de este ensayo: más mercado de competencia perfecta y más intervención. Menos concentración de poder. Más innovación. No centrarse en objetivos perversos, como el crecimiento del PIB, sino en la calidad de vida de las personas. Resumiendo, el Estado debe cambiar.

Aterrizando a campos concretos y, obviamente, sin ánimo de ser exhaustivo, el Estado debe destinar muchos más recursos y participar directamente en la investigación en energías renovables, nuevos materiales, nuevos recursos minerales, transporte, reciclado de plásticos y otros productos etc., de forma que también obtenga beneficios por la investigación y todo el conocimiento no quede en manos de grandes conglomerados empresariales. El panorama oscuro que he descrito puede aclararse gracias a los avances tecnológicos. Tal vez sea posible conseguir mucha más eficiencia en las placas solares con menos materiales o con materiales más abundantes. O fabricar baterías eléctricas empleando menor consumo energético. Mejoras en el sector del transporte serían decisivas, así como en el almacenamiento energético.

Ante el descenso en la producción de petróleo, son necesarias políticas que permitan el mayor autoabastecimiento posible de energía a las industrias y los hogares. Esto puede que tenga como consecuencia que un porcentaje elevado de la energía eléctrica se produzca a nivel local o que se emplee directamente la energía solar en los procesos productivos. Es posible que las empresas organicen su producción en función de las horas de sol, quién sabe. Hay que explotar las tecnologías que permiten la producción eléctrica a pequeña escala y la redistribución a nivel local y olvidar la situación actual, con unas pocas empresas dominando el mercado de la energía, con costosísimas plantas de producción de electricidad y poder monopolístico. El Estado también se podría involucrar directamente en el mercado energético. En el caso de que fuera necesario, ante situaciones en las que el mercado no puede funcionar sin generar graves perjuicios a la población, el Estado debe llegar incluso a decidir el destino de la energía que se produce y de planificar el sector. Por poner dos ejemplos, no se puede dejar morir de frío a ninguna persona y no se pueden dejar desabastecidos los hospitales. Pero estas actuaciones drásticas sólo deben tomarse si todo lo anterior se hace y falla. 
El Estado debe facilitar a los ciudadanos el empleo de otros medios de comunicación alternativos al automóvil que consuman menos energía, como bicicletas y vehículos ligeros. Y desarrollar un sistema de transporte público eficiente.

Se debe promover la eficiencia energética y la economía circular, mejorando las técnicas de reciclado y el diseño de los productos para facilitarlo. Se deben internalizar las externalidades.

La economía debe ser capaz de autoabastecerse de productos estratégicos y no depender de la producción en países lejanos, en un contexto en el que el precio del transporte puede subir o puede haber paradas en la cadena de suministros. En fin... las acciones que deben implementarse son muchas y variadas.

La quema masiva de combustibles fósiles ha emitido grandes cantidades de $\mathrm{CO} 2$ a la atmósfera y el nivel de concentración de este gas ha aumentado de forma significativa. No mucho en términos absolutos, pero sí lo suficiente como para provocar un aumento de la temperatura y desestabilizar el sistema climático global. Aunque ya se han quemado grandes cantidades, aún queda mucho petróleo y carbón disponible, no como para seguir alimentando un crecimiento del consumo energético como el actual durante cien años más, pero sí como para causar un aumento aún mayor de la temperatura media en el planeta.

\subsubsection{EL CAMBIO CLIMÁTICO}

Ya estamos sufriendo las consecuencias del cambio climático ocasionado por el calentamiento global que ha generado la quema de combustibles fósiles en las últimas décadas. Además, el aumento de consumo de carne de vacuno en el último siglo ha tenido como consecuencia un aumento de emisiones de metano, aumentando aún más el efecto invernadero. Todo ello ha generado que se inicien procesos naturales que acelerarán todavía más la emisión de gases de efecto invernadero, como el proveniente del permafrost de Siberia. Además, el cambio de temperatura hace que haya más vapor de agua en la atmósfera, aumentando aún más el efecto. Por si fuera poco, la desaparición de los casquetes polares y otros acontecimientos aceleran también el calentamiento global. 
El cambio climático también va a tener consecuencias difíciles de calibrar actualmente, dado que se siguen y se seguirán emitiendo a la atmósfera gases de efecto invernadero. Pero también es evidente que serán terribles. Todos los ecosistemas del planeta se están viendo ya afectados. Es posible que mermen las cosechas y haya sequías prolongadas. Si se producen hambrunas, habrá éxodos masivos de población. No se pueden descartar guerras para acceder al agua si ésta se convierte en un bien escaso. Desde la comodidad de un país desarrollado esta evolución parece inverosímil, pero no lo es en absoluto y no se puede descartar desabastecimientos. La subida del nivel del mar afectará especialmente a algunos países que llegarán a desaparecer. Muchos territorios dejarán de ser habitables. Los incendios forestales serán habituales. Los sucesos meteorológicos que hoy en día consideramos extremos pasarán a ser habituales. Al lector interesado en este tema le recomiendo que busque las noticias en internet.

Una vez más, podemos señalar a los Estados como corresponsables de esta situación, por acción y omisión. Las líneas de actuación generales son las mismas que las expuestas en el apartado anterior. Muchas de las actuaciones concretas señaladas también tendrán un impacto positivo en la lucha contra el cambio climático.

Además, es especialmente importante garantizar el abastecimiento de agua, alimentos y cierto grado de independencia alimentaria. Si hay escasez, el Estado deberá intervenir en los mercados, igual que en una economía de guerra. Pero esperemos que no se tenga que llegar a estos extremos. No será necesario si se toman las medidas necesarias a tiempo.

Por otro lado, los Estados deben preparar las infraestructuras básicas para soportar eventos meteorológicos extremos y estar alerta frente a la subida del nivel del mar.

Comentar finalmente la importancia de la información y la formación para que los ciudadanos, los votantes, sean conocedores de la situación, las amenazas futuras y su origen. Es función del Estado, por todos los medios a su disposición, como la televisión pública, mostrar la magnitud del problema y fomentar el debate acerca de cómo debe solucionarse, presentando las opciones reales y cómo les pueden afectar a los ciudadanos cada una de ellas. 
En los próximos años se avecinan cambios económicos muy profundos y será necesario, por el bienestar de la población, que el Estado pueda, al menos, encauzarlos. Porque los cambios se van a producir, son inevitables. Cambio climático, falta de materias primas, crisis energética: se acabó el crecimiento económico tal y como lo conocemos, tal y como lo medimos. Pero no tiene por qué ser un mundo peor. Nos va a tocar eliminar lo superfluo y vivir, tal vez, viajando menos, comiendo otras cosas, consumiendo menos. Menos comprar, usar, tirar. Menos derroche. Tendremos que aprender a valorar más lo que tenemos. No es un futuro tan malo.

Pero para poder capear el temporal es imprescindible que los Estados tomen medidas drásticas y cambien su forma de actuar. Es urgente cambiar de nuevo de paradigma. La intervención del Estado en la economía debe abandonar las políticas neomercantilistas actuales que benefician a corto plazo a unos pocos pero que nos abocan a todos al desastre. Tal y como hemos comentado, se debe modificar la actual política monetaria y la política fiscal. También la política redistributiva y la política de asignación de recursos. No obstante, realizar los cambios necesarios no será fácil. Hay demasiadas fuerzas inmovilistas que impiden que se tomen las decisiones adecuadas.

En primer lugar, los grupos de presión que quieren mantener su poder y tienen gran influencia en la agenda política y en los medios de comunicación. En todos los países. Y sin la colaboración coordinada de todas las potencias económicas es difícil resolver los problemas globales.

En segundo lugar, los propios votantes. Los ciudadanos estamos acostumbrados a una forma de vida concreta y se pondrán obstáculos a cualquier política que implique un cambio sustancial aunque necesario.

Tal y como dice Isaac Asimov en su novela "Los propios dioses":

“No puedes meter al pollo de nuevo en su cascarón, no puedes convertir el vino en uvas, ni introducir a un niño de nuevo en el útero. Si quieres que el niño deje en paz tu reloj, no puedes explicarle sencillamente que no debe tocarlo... tienes que ofrecerle algo que le guste más a cambio." 
Esa debiera ser una de las actuaciones inmediatas del Estado: advertir de los problemas, enseñar que es imposible que la economía siga como hasta ahora y proponer una economía alternativa que sea atractiva, en la medida en que permita crear un contexto económico y social en el que, sin derroches e ineficiencias, el ser humano pueda desarrollar su personalidad y, bajo su responsabilidad, intentar ser feliz. 


\section{BIBLIOGRAFÍA}

Asimov, I. (1972). Los propios dioses. (Edición 2005) La factoría de ideas. (pag. 274)

Bustos Gisbert, A. (2003). Lecciones de Hacienda Pública I. El papel del Sector Público. ( $3^{\mathrm{a}}$ edición). Editorial Colex.

Constitución Española. Texto consolidado. Última modificación: 27 de septiembre de 2011.

Dannoritzer, C. (Directora). (2011). Comprar, tirar, comprar. [Documental]. Article Z; Media 3.14

Diamond, J. (1997). Armas, gérmenes y acero. (Edición 2006). Debate Editorial

Fergusson, C. (Director). (2010). Inside Job [Documental]. Sony Pictures Distribution.

Fondo Monetario internacional. World Economic Outlook Databases.

https://www.imf.org/en/Publications/SPROLLs/world-economic-outlook-

databases\#sort=\%40imfdate\%20descending Consultado en agosto de 2021.

García, F. (2012). Participación ciudadana, democracia y crisis económica. Edición del autor.

Klein, N. (2007). La doctrina del shock. El auge del capitalismo del desastre. (Edición 2012) Planeta.

Lazarillo de Tormes. 2002. Susaeta.

Naciones Unidas. (1948). Declaración Universal de los Derechos Humanos. Adoptada proclamada por la Asamblea General en su Resolución 217 A (iii), de 10 de diciembre de 1948.

Montero, D. (2009). La Casta, el increíble chollo de ser político en España. (3a edición). La esfera de los libros

Montero de Burgos, J.L. (1971). Propiedad, capital, trabajo. Edición del autor.

Ortega y Gasset, J. (1948). La rebelión de las masas. Espasa-Calpe.

Robin, M.M. (Directora). (2008). El mundo según Monsanto. [Documental]. National Film Board of Canada.

Segura, L.G. (2017). El libro negro del ejército español. (3ª edición). Akal. 
Stiglitz, J. (2000) La economía del sector público. (3ª edición). Antoni Bosch editor.

Stiglitz, J. (2002). El malestar en la globalización. (11 a edición). Taurus.

Torres López, J. (2019). La renta básica. Deusto.

Turiel, A. Petrocalipsis. Crisis energética global y cómo (no) la solucionaremos. Alfabeto.

Turiel, A. The oil crash. crashoil.blogspot.com

Unión Europea. Tratado de la Unión Europea, firmado en Maastricht el 7 de febrero de 1992. Diario Oficial de las Comunidades Europeas, 29 de julio de 1992, núm. 191.

Whitmore, P., Lotterby, S., Allen, S. (Productores). (1980-1984). Yes, Minister [Serie de televisión]. BBC 



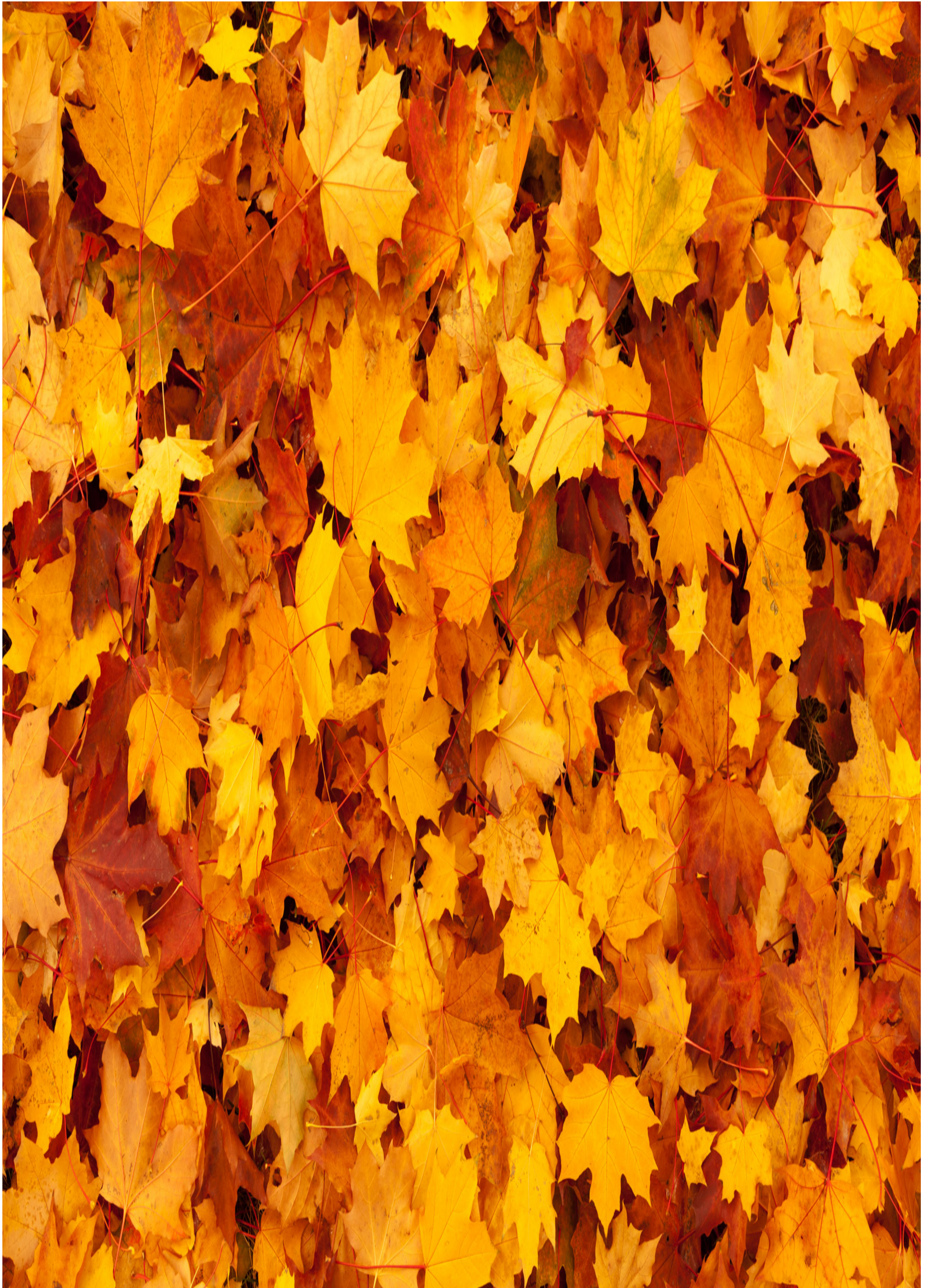

